
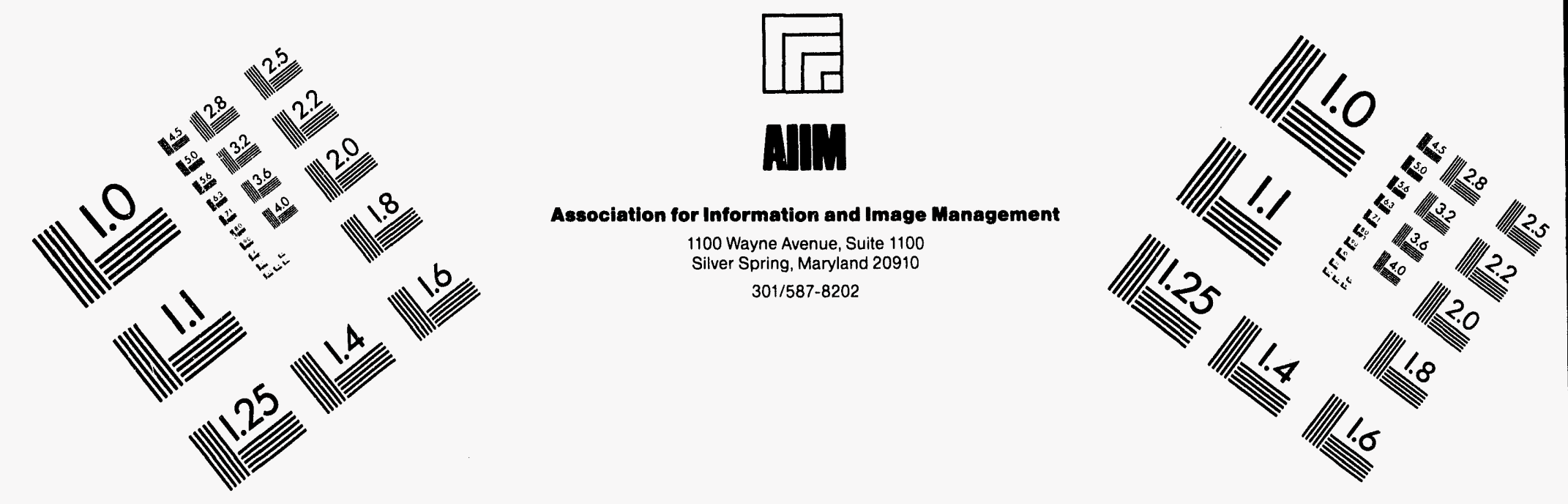

Centimeter

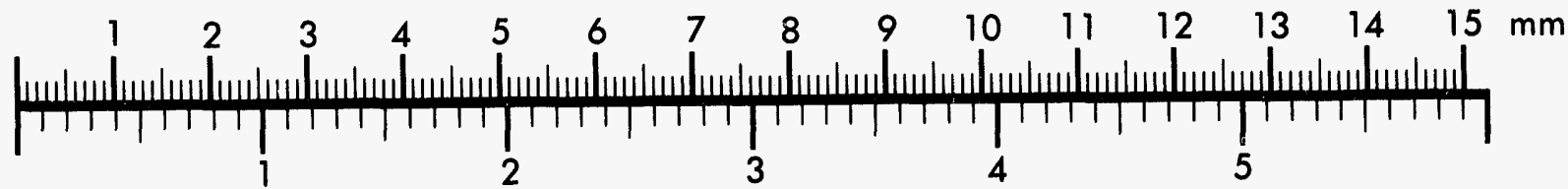

Inches
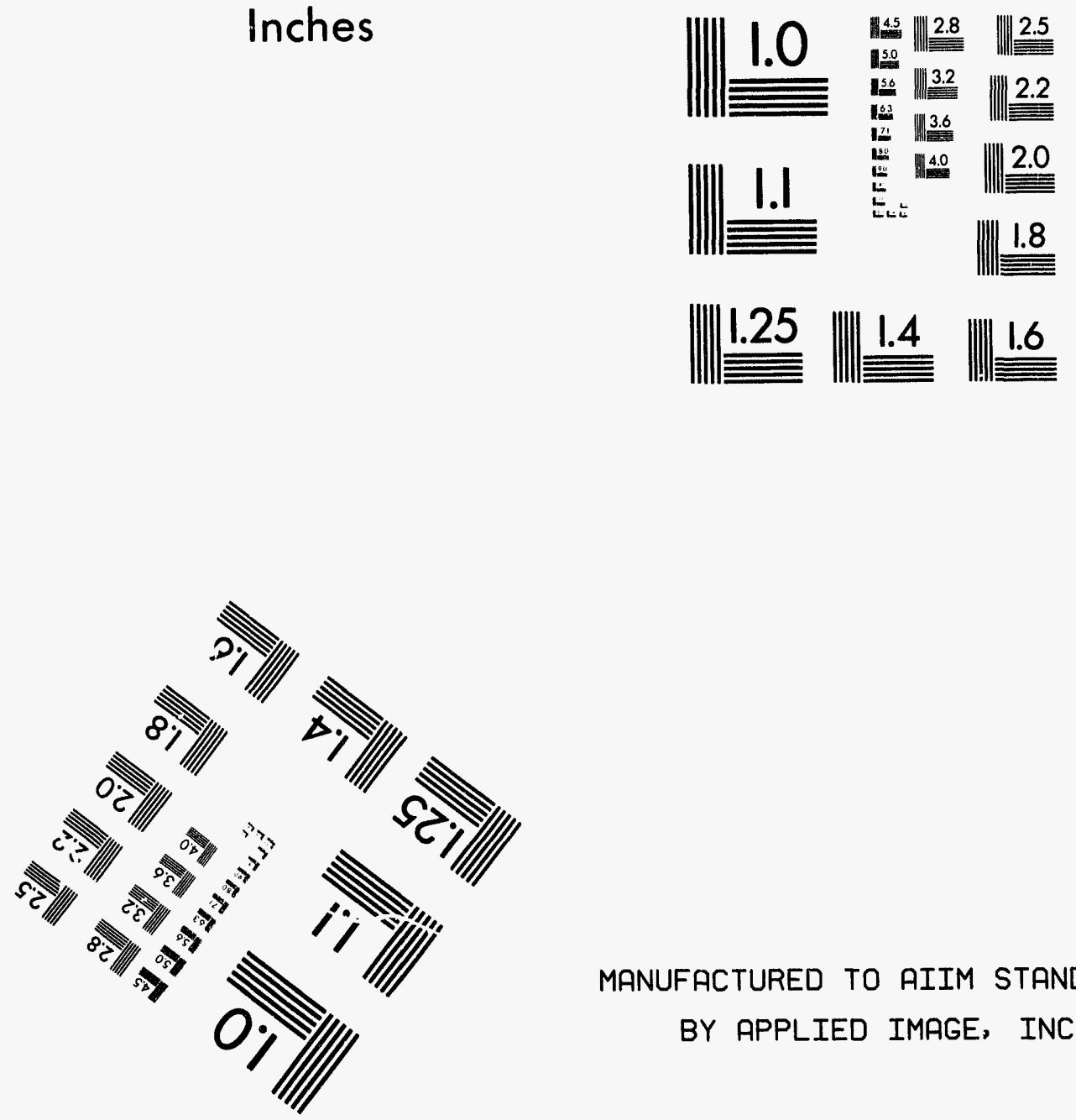

MANUFACTURED TO AIIM STANDARDS
BY APPLIED IMAGE, INC.

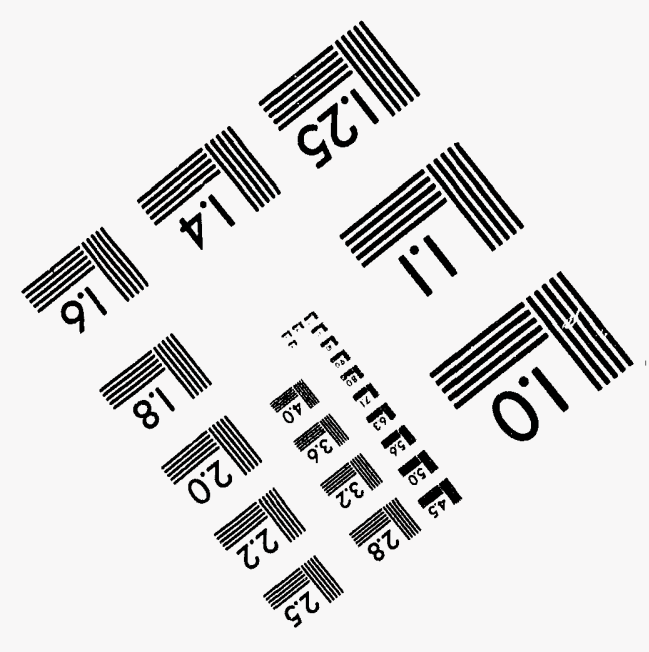



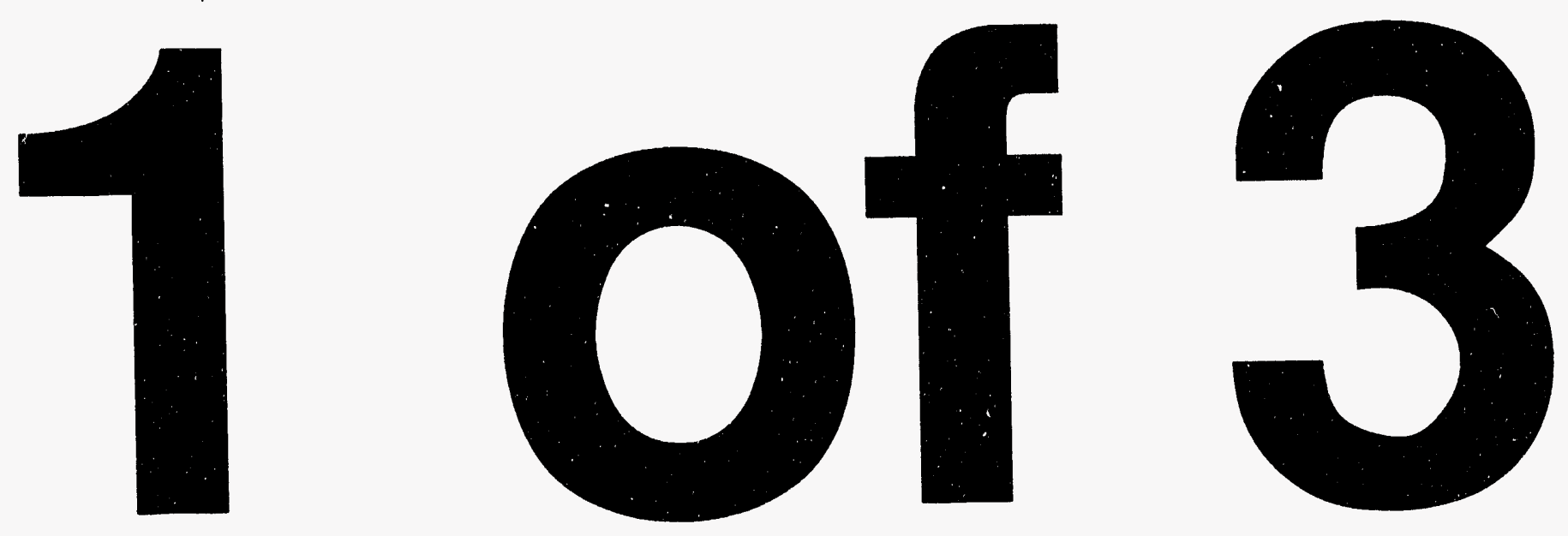
NUREG-1503

Vol. 2

\section{Final Safety Evaluation Report \\ Related to the Certification \\ of the Advanced Boiling Water \\ Reactor Design}

Appendices

Manuscript Completed: July 1994

Date Published: July 1994

Associate Directorate for Advanced Reactors and License Renewal

Office of Nuclear Reactor Regulation

U.S. Nuclear Regulatory Commission

Washington, DC 20555-0001

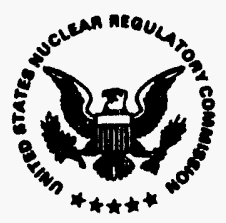




\begin{abstract}
This safety evaluation report (SER) documents the technical review of the U.S. Advanced Boiling Water Reactor (ABWR) standard design by the U.S. Nuclear Regulatory Commission (NRC) staff. The application for the ABWR design was initially submitted by the General Electric Company, now GE Nuclear Energy (GE), in accordance with the procedures of Appendix $O$ of Part 50 of Title 10 of the Code of Federal Repulations (10 CFR Part 50). Later GE requested that its application be considered as an application for design approval and subsequent design certification pursuant to 10 CFR \$ 52.45.

The U.S. ABWR design is similar to the international ABWR design, which was being built at the Kashiwazaki Kariwa Nuclear Power Generation Station, at the time of the staff's review, by the Tokyo Electric Power Company, Inc. The ABWR is a single-cycle, forced-circulation, boiling water reactor (BWR) with a rated power of 3926 megawatts thermal (MWt) and a design power of $4005 \mathrm{MWt}$. Many features of the ABWR design are similar to those of BWR designs that the staff had previously approved. To the extent feasible and appropriate, the staff relied on earlier reviews for those

$A B W R$ design features that are substantially the same as those previously considered. The SERs for the other BWR designs have been published and are available for public inspection at the NRC Public Document Room, 2120 L Street, N.W., Washington, D.C. 20037. Unique features of the ABWR design include internal recirculation pumps, fine-motion control rod drives, microprocessorbased digital logic and control systems, and digital safety systems.

On the basis of its evaluation and independent analyses, the NRC staff concludes that, subject to satisfactory resolution of the confirmatory items identified in Section 1.8 of this SER, GE's application for design certification meets the requirements of Subpart B of 10 CFR Part 52 that are applicable and technically relevant to the U.S. ABWR standard design. A copy of the report by the Advisory Committec on Reactor Safeguards required by 10 CFR \& 52.53 is provided in Chapter 21. A final design approval, issued on the basis of this SER, does not constitute a commitment to issue a permit or license, or in any way affect the authority of the Commission, the Atomic Safety and Licensing Board, and other presiding officers, in any proceeding pursuant to Subpart $G$ of 10 CFR Part 2.
\end{abstract}




\section{CONTENTS}

\section{VOLUME 2: APPENDICES}

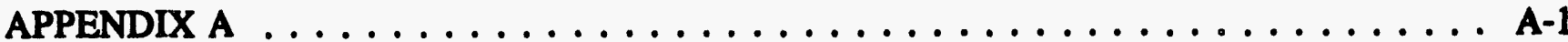

LIST OF ABBREVIATIONS $\ldots \ldots \ldots \ldots \ldots \ldots \ldots \ldots \ldots \ldots \ldots \ldots \ldots \ldots \ldots$

APPENDIX B $\ldots \ldots \ldots \ldots \ldots \ldots \ldots \ldots \ldots \ldots \ldots \ldots \ldots \ldots \ldots \ldots \ldots \ldots$

REFERENCES $\ldots \ldots \ldots \ldots \ldots \ldots \ldots \ldots \ldots \ldots \ldots \ldots \ldots \ldots \ldots \ldots \ldots \ldots \ldots \ldots$

APPENDIX $\mathrm{C} \ldots \ldots \ldots \ldots \ldots \ldots \ldots \ldots \ldots \ldots \ldots \ldots \ldots$

CHRONOLOGY OF CORRESPONDENCE $\ldots \ldots \ldots \ldots \ldots \ldots \ldots \ldots \ldots \ldots \ldots \ldots$

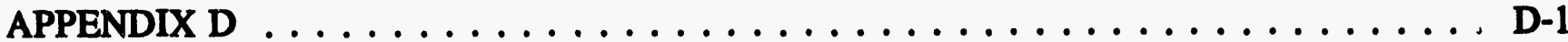

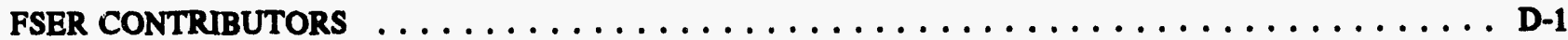

APPENDIX E ................................ E-1

STAFF POSITION ON SHELL BUCKLING DUE TO INTERNAL PRESSURE . . . . . . . . . . E-1

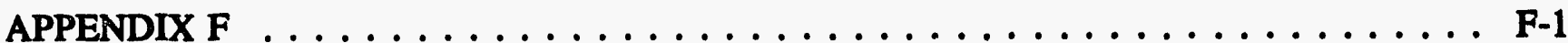

STAFF POSITION ON STEEL EMBEDMENTS $\ldots \ldots \ldots \ldots \ldots \ldots \ldots \ldots \ldots \ldots \ldots \ldots \ldots$ F-1

APPENDIX G ...............................G-1

STAFF POSITIONS AND TECHNICAL BASES ON THE USE OF AMERICAN NATIONAL

STANDARDS INSTITUTE (ANSD)/AMERICAN INSTITUTE OF STEEL CONSTRUCTION

(AISC) N690, "NUCLEAR FACILTIIES - STEEL SAFETY-RELATED STRUCTURES" . . . . . . . . G-1

APPENDIX H ............................ H-1

DYNAMIC LATERAL SOIL PRESSURES ON EARTH RETAINING WALLS AND EMBEDDED

WALLS OF NUCLEAR POWER PLANT STRUCTURES $\ldots \ldots \ldots \ldots \ldots \ldots \ldots \ldots \ldots \ldots$ H-1

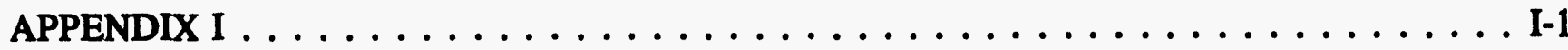

EVALUATION OF ABWR PUMP AND VALVE INSERVICE TESTING PLAN

(SSAR TABLES $3.9-8$ AND $3.9-9) \quad \ldots \ldots \ldots \ldots \ldots \ldots \ldots \ldots \ldots \ldots \ldots \ldots \ldots \ldots \ldots \ldots$

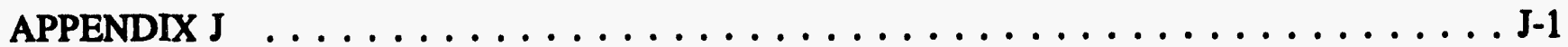

HUMAN FACTORS ENGINEERING PROGRAM REVIEW MODEL AND ACCEPTANCE CRITERIA FOR EVOLUTIONARY REACTORS

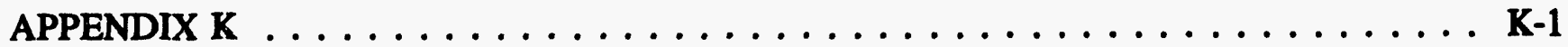

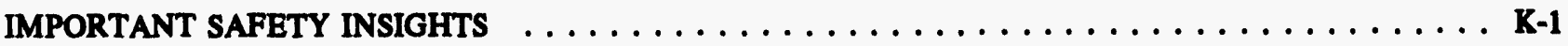




\section{FIGURES}

G-1 Structural stability curves for the axially loeded compression numbers. $\ldots \ldots \ldots \ldots \ldots \ldots$

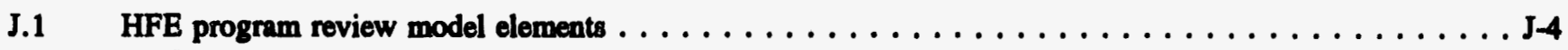

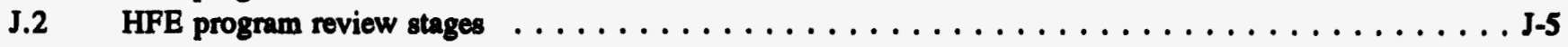




\section{Appendix A}

\section{LIST OF ABBREVIATIONS}

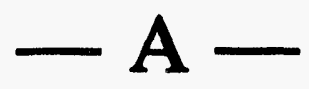

ABWR advanced boiling water reactor

AC

alternating current

ACC

ACI

ACIWA

ACRS

ACS

ACU

ADS

AHU

AISC

ALARA

ALWR

AM

ANL

ANS

ANSI

AOO(s)

APR

APRM

ARI

ARS

ASB

ASCE

ASD

ASD

ASF

ASHRAE

ASME

ASTM

ATIP

ATLM

ATWS

BNL

BPU

BPWS

BTP

BWR

BWROG accumulator

automatic closure and interlock

ac-independent water addition

Advisory Committee on Reactor

Safeguards

atmospheric control system

air conditioning units

automatic depressurization system

air handling units

American Institute of Steel Construction

as low as is reasonably achievable

advanced light water reactor

accident management

Argonne National Laboratory

American Nuclear Society

American National Standards Institute

anticipated operational occurrences

automatic power regulator

average power range monitor

alternate rod insertion

amplified response spectra

Auxiliary Systems Branch

American Society of Civil Engineers

allowable stress design

adjustable speed drive

automatic suppression function

American Society of Heating,

Refrigeration, and Air Conditioning

Engineers

American Society of Mechanical Engineers

American Society for Testing and

Materials

automatic transversing in-core probe

automated thermal limit monitor

anticipated transient without scram

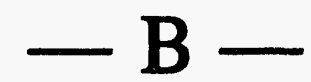

Brookhaven National Laboratory

bypass unit

blanked position withdrawal sequence

Branch Technical Position

boiling water reactor

BWR Owners Group

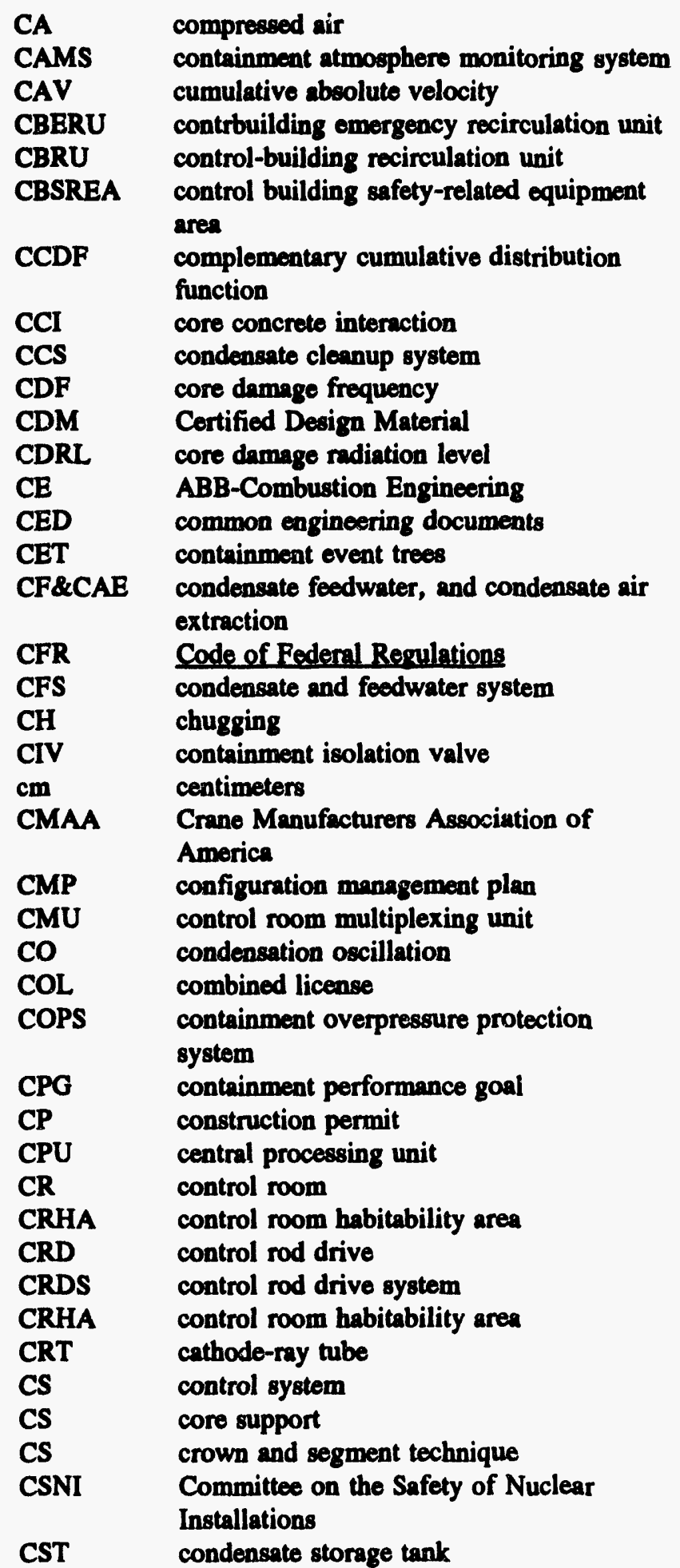

CAMS containment atmosphere monitoring system

CAV cumulative absolute velocity

CBERU contrbuilding emergency recirculation unit

CBRU control-building recirculation unit

area

CCI function

CCS condensate cleanup system

CDF core damage frequency

CDM Certified Design Material

CDRL core damage radiation level

CE

CED

CET

ABB-Combustion Engineering

common engineering documents

condensate feedwater, and condensate air

extraction

condensate and feodwater system

chugging

centimeters

Crane Manufacturers Associution of

America

CMP configuration management plan

CMU

$\mathrm{CO}$

COL

CPG

CP

CPU

CR

CRHA

CRD

CRDS

CRHA 


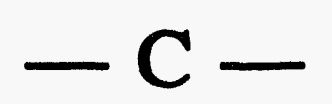

CT

CTG

CUW

CVCF

CWS design description

damage control center

design control document

damage control measure

Tier 1 Design Certification Material for the GE ABWR

DCV

DEPSS

DET

DF

DFSER

DG

DGCW

DGL

DGSA

DMC

DOD

DOE

dp

DRAP

DSER

DSIL

DTM

DTS

EAB

EB

EBVS

ECCS drywell connecting vent

drywell equipment and piping support structure

decomposition event tree

docontamination factor

draft final safety evaluation report

diesel generator

diesel generator cooling water

diesel generator lubrication

diesel generator starting air

digital measurement and control

Department of Defense

Department of Energy

deltap

design reliability assurance program

draft safety evaluation report

drywell spray initiation limit

digital trip module

drain transfer system

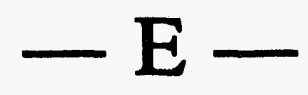

exclusion area boundary

electrical building

electrical building ventilation system

emergency core cooling system(s)
EDG

EDO

EF

EFU

EHR

EMC

EMI

EMS

EOF

EOP

EPA

EPG

EPRI

ERM

EQ

EQD

ESD

ESF

ESW

emergency diesel generator

Executive Director for Operations

error factor

emergency filiration unit

extra hard rock

electronic magnetic compatibility

electromagnetic interference

essential multiplexing system

Emergency Operations Facility

emergency operating procedures

electrical protection assemblies

emergency procedure guidelines

Electric Power Research Institute

Engineering Review Memorandum

environmental qualification

environmental qualification document

electmstatic discharge

engineered safety feature

essential service water

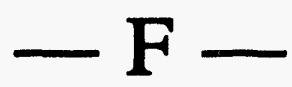

FATT fracture appearance transition temperature

FCI fuel-coolant interactions

FCS flammability control system

FCU fan cool unit

FDA

FDDI

FDWC

FDDI

FIST

FIVE

FMCRD

final design approval

fiber distribution data interface

feedwater control

fiber distributed data interface

full integral simulation test

fire-induced vulnerability evaluation

FMEA

FOST

FPC

FRS

FS

FSER

fi

FWLB

fine-motion control rod drive

failure modes and effects analysis

fuel oil storage and transfer

fuel pool cooling and cleanup

floor response spectra

full-scale

final safety evaluation report

feet

feedwater line break

GDC

GE

GI

GL

GSI

GWd

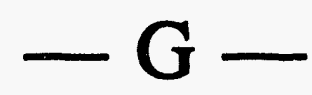

general design criteria/criterion

GE Nuclear Energy

generic issue

generic letter

generic safety issue(s)

gaseous waste management system 


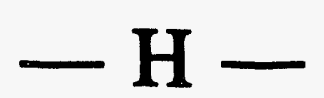

HCLPF high confidence low probability of failure

HCTL

HCW

HCU

HECW

HELB

HELSA

HEPA

HF

HI

HFE

HFPP

HIC

HNCW

HPCF

HPCS

HPIN

HPME

HR

HRA

HSD

HSI

HVAC

HWC

HWH

I\&C

IA

IBD

ICC

ICD

IE

IED

IEEE

IGSCC

ILRT

IN

in.

IORV

ISI

ISM

ISO

IST

ITAAC

ITP

high confidence low probability of failure

heat capacity temperature limit

high-conductivity waste

hydraulic control unit

HVAC emergency cooling water

high-energy line breaks

high-energy line separation analysis

high-efficiency particulate air

human factors

hydraulic institute

human factors engineering

human factors program plan

high-integrity containers

HVAC normal cooling water

high-pressure core flooder

high-pressure core spray

high-pressure nitrogen gas supply

high-pressure core melt ejection system

hard rock

human reliability analysis

hot shower drain

human system interface

heating, ventilating, and air conditioning

hydrogen water chemistry

hot water heating

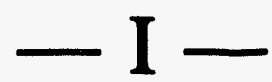

instrumentation and control

instrument air

instrument block diagrams

inadequate core cooling

interface control diagram

Inspection and Enforcement

improvised explosive device

Institute of Electrical and Electronics

Engineers

intergranular stress corrosion cracking

integrated leakage rate tests

information notice

inch

inadvertent open relief valve

inservice inspection

independent support motion

isometric drawing(s)/International Systems

Interconnection

inservice testing

inspections, tests, analyses, and acceptance

criteria

initial test program'

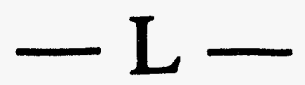

LBB leak-beforo-break

LCS leakage control system

LCS local control switches

LCW low-conductivity waste

LD lower drywell

LDF lower drywell flooder

LDS

LER

LLHS

LLNL

LLRT

LOCA

LOOP

LOPP

LPCI

LPFL

LPMS

LPRM

LPZ

LRB

LRFD

LTS

LVDT

LWMS

LWR

leak detection and isolation system

licensee event reports

light load handling system

Lawrence Livermore National Laboratory

local leak rate tests

loss-of-coolant accident

loss-of-offsite power

loss-of-preferred power

low-pressure coolant-injection

low-pressure flooder

loose parts monitoring system

local power range monitor

low-population zone

Licensing Review Bases

load and resistance factor design

long term solutions

linear variable differential transformers

liquid waste management system

light water reactor

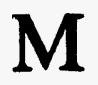

m meters

M-O Mononobe and Okabe

MACCS melcor accident consequence code system

MAPLHGR maximum average planar linear heat

generation rate

MC main condensers

MCAE main control area envelope

MCC motor control center

MCES main condenser evacuation system

MCPR minimum critical power ratio

MCR

MEB

MG

ML

$\operatorname{MOV}(\mathbf{s})$

MPL(s)

MPT

MRBM

MS

MSIV

MSL

MSLB main control room

Mechanical Engineering Branch

motor-generator

manufacturing license

motor operated valves

master parts lists

main power transformer

multi-channel rod block monitor

main steam

main steamline isolation valves

main steamline

main steamline break 


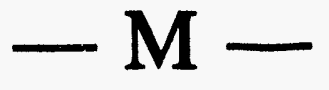

MST

MTU

MUWC

MUWP

MVA

MWP

Mwt

NB nuclear boiler

NBS

NDE

NEMA

NEMS

NFPA

NMS

NNS

NPB

NPP

NPSH

NQA

NRC

NRD

NRHX

NSSFC

NSSS

OBE

OER

OHLHS

OLU

OL

OM

OPRM

O-RAP

ORNL

OSC

OSI

main steam tunnel

metric ton of uranium

makeup water (condensate)

megavolt amps

makeup water system

megawatt thermal

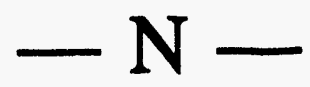

nuclear boiling system

Association

non-nuclear safety

nuclear power block

nuclear power plant

net positive suction head

nonradioactive drain

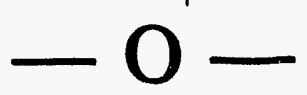

output logic unit

operating license makeup water system (purified)

non-destructive examination

National Electrical Manufacturers

non-essential multiplexor system

National Fire Protection Association

neutron monitoring system

Nuclear Quality Assurance

Nuclear Regulatory Commission

non-regenerative heat exchangers

National Severe Storm Forecast Center

nuclear steam supply system(s)

operating basis earthquake

operating experience review

overhead heavy load handling system

operations and maintenance

oscillation power range monitor

operational reliability assurance process

Oak Ridge National Laboratory

Operational Support Center

open systems interconnection

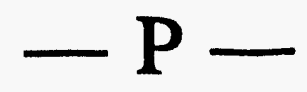

P\&ID

PASS

PCHS piping and instrumentation diagram(s)

post-accident sampling system

power cycle heat sink
PCP

PCPL

PCT

PDA

PFD

PGA

PGCS

PIP

PM

POV

PRA

PRC

PRM

PRM

PRMS

PRNM

PS

PSA

PSB

PSD

PSDF

PSI

PSIS

PSS

PSTF

Q

QA

QG

RAI

RAP

RB

RBM

RBV

RBVS

RCCV

RCIC

RCIS

RCPB

RCS

RCW

RCWS

RFC

RFCS

RG

RH

RHR process control program

primary containment pressure limit

peak cladding temperature

preliminary design approval

process flow diagrams

peak ground acceleration

power generation control system

plant investment protection

preventive maintenance

powered operated valves

probabilistic risk assessment

Piping Review Committee

process radiation monitor

Program Review Model

process radiation monitoring system

power range neutron monitor

pressed and spun

probabilistic safety assessment

Power Systems Branch

power spectrum density

power spectral density function

preservice inspection

pounds per square inch gauge

process sampling system

pressure suppression test facility

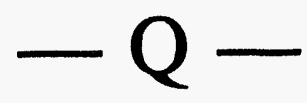

question

quality assurance

quality group<smiles>[R]</smiles>

request for additional information

reliability assurance program

reactor building

rod-block monitor

reactor building vibration

reactor building ventilation system

reinforced concrete containment vessel

reactor core isolation cooling

rod control and information system

reactor coolant pressure boundary

reactor coolant system

reactor building cooling water

reactor building cooling water system

recirculation flow control

recirculation flow control system

Regulatory Guide

relative humidity

residual heat removal 


\section{- R -}

RICSIL rapid communication service information letters

$\begin{array}{ll}\text { RIP } & \text { reactor internal pump } \\ \text { RMC } & \text { recirculation motor cooling } \\ \text { RMS } & \text { radiation-monitoring system } \\ \text { RMU } & \text { remote multiplexing units } \\ \text { RPCS } & \text { rod pattern control system } \\ \text { RPS } & \text { reactor protection system } \\ \text { RPT } & \text { recirculation pump trip } \\ \text { RPV } & \text { reactor pressure vessel } \\ \text { RSS } & \text { remote shutdown system } \\ \text { RSW } & \text { reactor service water } \\ \text { RTD } & \text { resistance temperature detectors } \\ \text { RT } & \text { nil ductility transition temperature } \\ \text { RTNSS } & \text { regulatory treatment of non-safety systems } \\ \text { RWCS } & \text { reactor water cleanup system } \\ \text { RWCU } & \text { reactor water cleanup } \\ \text { RWS } & \text { radwaste system }\end{array}$

\section{$-\mathbf{S}$}

SA service air

SAIC Science Applications International

SAM

SAMDA

SB\&PC

SBO

SC

SCG

SCAM

SCRAM

SCRRI

SCSB

SDC

SDS

SER

SERG

SFA

SFP

SGTS

SIL

SIT

SJAE

SLU

SLC

SLCS

SOMP

\section{seismic anchor motions}

severe accident mitigation design

alternative

steam bypass and pressure control

station blackout

safety class

startup coordinating group

subcompartment anklysis method

reactor trip (safety control rod axe man)

selected control rod run-in

Containment Systems and Severe Accident

\section{Branch}

\section{shutdown cooling}

system design specification

safety evaluation report

Steam Explosion Review Group

spent fuel assemblies

spent fuel pool

standby gas treatment system

service information letters

structural integrity test

steam jet air ejector

system logic unit

standby liquid control

standby liquid control system

software operation and maintenance plan

\section{Corporation}

SPCU

SPDS

SPTM

SQA

SRI

SRM

SRNM

SRP

SRSS

SRV

SS

SS

SSAR

SSC

SSE

SSI

SSLC

STS

STS

STUDH

TA

TAF

TB

TBS

TBVS

TCA

TCW

TEMA

TGS

TGSS

TID

TIP

TLU

TMI

TS

TSC

TSW

UAT

UBC

UD

UHS

URS

USI suppression pool cleanup

safety parameter display system

suppression pool temperature monitoring

software QA

select rod insert

staff requirements memorandum

startup range neutron monitoring system

standard review plan

square-root-of-sum-of-squares

safety relief valve

shift supervisor

sub-scale

standard safety analysis report

structures, systems, and components

safe shutdown earthquake

seismic soil-structure interaction

safety system logic and control

self-test system

standard tochnical specification

Steel torispherical upper drywell head

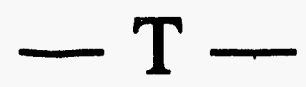

technical associate

top of the active fuel

turbine building

turbine bypass system

turbine building ventilation system

Technical Cooperation Agreement

turbine building cooling water

Tank Equipment Manufacturers

Association

turbine generator system

turbine gland sealing system

Technical Information Document

traversing incore probe

trip logic units

Three Mile Island

technical specification(s)

Technical Support Center

service water system

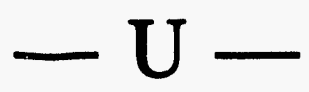

unit auxiliary transformers

Uniform Building Code

upper drywell

ultimate heat sink

ultimate rupture strength

unresolved safety issue(s) 


\section{Appendix A}

$$
-\mathrm{V}-
$$

V\&V verification and validation

V\&VP verification and validation plan

VDU video display units

VPI valve position indicatication 


\section{APPENDIX B}

\section{REFERENCES}

American Concrete Institute, 349, "Code Requirements for Nuclear Safety-Related Concrete Structures," (1980 Edition).

\section{American Institute of Steel Construction}

Manual of Steel Construction, "Specification for the Design, Fabrication and Erection of Structural Steel for Buildings," Chicago, Illinois, 1989.

Publication No. T114, "Torsional Analysis of Stoel Members," Chicago, Illinois, February 1983.

American Iron and Steel Institute, SG-673-1986, "Specification for the Design of Cold-Formed Steel Structural Members, " 1986, Washington, D.C.

\section{American National Standards Institute}

ASC X3T9.5 (1988), "Fiber Distributed Data Interface (FDDI)."

C37.06-1987, "Preferred Ratings and Related Capabilities for ac High-Voltage Circuit Breakers Rated on a Symmetrical Current Basis."

C57.12.00, "General Requirements for Liquid-Immersed Distribution, Power, and Regulating Transformers."

MC 11.1-1976, "Quality Standard for Instrument Air."

N13.1-1969, "Guide for Sampling Airborne Radioactive Materials in Nuclear Facilities."

N14.6-1986, "Standard for Special Lifting Devices for Shipping Containers Weighing 10,000 Pounds $(4500 \mathrm{Kg})$ or More for Nuclear Materials."

N45.2.1-1973, "Cleaning of Fluid Systems and Associated Components During Construction Phase of Nuclear Power Plants."

N45.2.5-1974, "Supplementary Quality Assurance Requirements for Installation Inspection, and Testing of Structural Concrete and Structural Steel During Construction Phase of Niclear Power Plants."

N101.2-1972, "Protective Caatings (Paints) for Light Water Reactor Containment Facilities. "

N101.4-1972, "Quality Assurance for Protective Coatings Applied to Nuclear Facilities."
N170-1976, "Standards for Determining Design Basis Flooding at Power Reactor Sites."

N195/ANS59.51-1976, "Fuel Oil Systems for Emergency Diesel Generators."

\section{American National Standards Institute/ American Institute of Steel Construction}

"Load and Resistance Factor Design Specification for Structural Steel Buildings and Its Commentary," Chicago, Illinois, September 1, 1986.

Standard N-690, "Specification for the Design, Fabrication, and Erection of Steel Safety-Related Structures for Nuclear Facilities, " Chicago, Illinois (1984 Edition).

T114-2/83, "Torsional Analysis of Steel Members."

\section{American National Standards Institute/ American Nuclear Society}

2.3-1983, "Standard for Estimating Tornado and Extreme Wind Characteristics at Nur! ar Power Sites, " ANS, La Grange Park, Illinois.

2.8-1981, "Determining Design Basis Flooding at Power Reactor Sites."

18.1-1984, "Radionctive Source Term for Normal Operation of LWRs."

52.1-1983, "Nuclear Safety Design Criteria for the Design of Stationary Boiling Water Reactor Plants."

52.2-1983, "Nuclear Safety Criteria for the Design of Stationary Boiling Water Reactor Plants. "

56.2-1976, "Containment Isolation Provisions for Fluid Systems After a LOCA."

56.11-1988, "Standard Design Criteria for Protection Against the Effects of Compartment Flooding in Light Water Reactor Plants."

57.1-1980, "Design Requirements for Light Water Reactor Fuel Handling Systems."

57.2-1976, "Requirements for Light Water Reactor Spent Fuel Storage Facilities at Nuclear Power Plants, Design." 
58.2-1988, "Design Basis for Protection of Light Water Nuclear Power Plants Against the Effects of Pipe Rupture."

58.8-1984, "Time Response Design Criteria for Nuclear Safety Related Operator Actions."

American National Standards Institute/ American Society of Mechanical Engineers

NQA-2-1989, Part 2.7, "Quality Assurance

Requirements of Computer Software for Nuclear Facility Applications," NQA-2a-1990 Addenda.

N509-1989, "Nuclear Power Plant Air-Cleaning Units and Components."

N510-1989, "Testing of Nuclear Air-Cleaning System. "

ASME AG-1-1993 and AG-1a-92 Addenda, "Code on Nuclear Air and Gas Treatment."

ASME B30.11-1980, "Monorails and Underhung Cranes."

ASME B30.16-1981, "Overhead Hoists."

ASME B30.10-1982, Hooks."

ASME B31.1-1986, "Power Piping."

ASME B30.2-1983, "Overhead and Gantry Cranes (Top Running Bridge, Single or Multiple Girder, Top Running Trolley Hoist)."

ASME B30.9-1984, "Slings."

\section{Operation and Maintenance of Nuclear Power Plants}

OM-1, "Requirements for Issuance Performance Testing of Nuclear Power Plant Pressure Relief Devices," OMa1988 to OM-1987.

ASME OM-S/G-1990, Part 3, "Requirements for Preoperational and Initial Start-Up Vibration Testing of Nuclear Power Plant Piping Systems," New York, 1990.

OM-6, "Inservice Testing of Pumps," 1988 Addenda.

ASME/ANSI OM, Part 7 (Draft-Rev. 7), "Requirements for Thermal Expansion Testing of Nuclear Power Plant Piping Systems," New York, September 1986.

OM-10, "Inservice Testing of Valves," 1988 Addenda.
American National Standards Institute/ Institute of Electrical and Electronics Engineers

279-1971, "Criteria for Protection Systems for Nuclear Power Generating Stations."

308-1974, "IEEE Standard Criteria for Class 1E Power Systems for Nuclear Power Generating Stations."

308-1980, "IEEE Standard Criteria for Class 1E Power Systems for Nuclear Power Generating Stations."

308-1992, "IEEE Standard Criteria for Class 1E Power Systems for Nuclear Power Generating Stations."

323-1974, "Qualifying Class 1E Equipment for Nuclear Power Generating Stations."

338-1977, "Criteria for the Periodic Testing of Nuclear Power Generating Station Safety Systems."

338-1987, "Criteria for the Periodic Testing of Nuclear Power Generating Station Safety Systems."

344-1987, "IEEE Recommended Practices for Seismic Qualification of Class 1E Equipment for Nuclear Power Generating Stations."

379-1977, "Standard Application of the Single Failure Criterion to Nuclear Power Generating Station Class 1E Systems."

384-1974, "IEEE Standard Criteria for Independence of Class 1E Equipment and Circuits."

384-1992, "IEEE Standard Criteria for Independence of Class 1E Equipment and Circuits."

384-1981, "IEEE Standard Criteria for Independence of Class 1E Equipment and Circuits."

387-1984, "Standard Criteria for Diesel-Generator Units Applied as Standby Power Supplies for Nuclear Power Supplies for Nuclear Power Generating Stations."

450-1985, "IEEE Recommended Practice for Maintenance, Testing, and Replacement of Large Lead Storage Batteries for Generating Stations and Substations."

472-1974, "IEEE Guide for Surge Withstand Capability (SWC) Tests." 
485-1983, "Recommended Practice for Sizing LargeLead Storage Batteries for Generating Stations and Substations."

518-1982, "Guide for the Installation of Electrical Equipment to Minimize Elecirical Noise Inputs to Controllers from External Sources."

603-1980, "IEEE Standard Criteria for Safety Systems for Nuclear Power Generating Stations."

665, "Guide for Generation Station Grounding."

730-1984, "IEEE Standard for Software Quality Assurance Plans."

741-1986, "Standard Criteria for the Protection of Class 1E Power Systems and Equipment in Nuclear Power Generating Stations."

765-1983, "Standard for Preferred Power Supply for Nuclear Power Generating Stations."

802.2-1985, "Standard for Local Area Networks: Logical Link Control."

802.5-1985, "Token Ring Access Method and Physical Layer Specifications."

828-1983, "IEEE Standard for Software Configuration Management Plans."

829-1983, "IEEE Standard for Software Test Documentation."

830-1984, "IEEE Standard for Software Requirements Specifications."

946-1985, "Recommended Practice for the Design of Safety-Related dc Auxiliary Power Systems for Nuclear Power Generating Stations."

1012-1986, "IEEE Standard for Software Verification and Validation Plans."

1033-1985, "IEEE Recommended Practice of Application of IEEE Standard 828 to Nuclear Power Generation Stations."

1042-1987, "Guide to Software Configuration Management."

1050-1980, "IEEE Guide for Instrumentation and Control Equipment Grounding."
1228 (Draft), "Standard for Software Safety Plans."

ANS-7-4.3.2 (1982), "Application Criteria for Programmable Digital Computer Systems in Safety Systems of Nuclear Power Generating Stations,"

C37.90.2-1987, "IEEE Trial - Use Standard, Withstand Capability of Relay Systems to Radiated Electromagnetic Interference from Transceivers."

C62.41-1980, "Guide for Surge Voltages in LowVoltage AC Power Circuits."

C62.45-1987, "Guide on Surge Testing for Equipment Connected to Low-Voltage AC Power Circuits."

C63.12-1987, "American National Standard for Electromagnetic Comparability Limits - Recommended Practice."

American National Standards Institute/National Electrical Manufacturens Association, Standard FB 1, "Fittings and Supports for Conduit and Cable Assembles," 1977.

American Society for Testing and Materials, E-185-82, "Standard Recommended Practices for Surveillance Tests for Nuclear Reactor Vessels. "

\section{American Society of Civil Engineers}

7-88, "Minimum Design Loadings for Buildings and Other Structures."

Paper 3269, "Wind Faces on Strucures," Transactions, Vol.126, Part II.

4-86, "Seismic Analysis of Safety-Related Nuclear Structures and Commentary on Standard for Seismic Analysis of Safety-Related Nuclear Structures," September 1986.

American Society of Heating, Refrigeration and Air Conditioning Engineers, "Design of Smoke Control Systems for Buildings."

\section{American Society of Mechanical Engineers}

\section{Boiler and Pressure Vessel Code}

Code Case N-71-15, "Additional Materials for Subsection NF, Clesses 1, 2, 3, and MC Component Supports Fabricated by Welding, Section III, Division 1." 


\section{Appendix B}

Code Case N-122, "Stress Indices for Structure Attachments, Class 1, Section III, Division 1."

Code Case N-247, "Certified Design Report Summary for Component Standard Supports, Section III, Division 1, Classes 1, 2, 3 and MC."

Code Case N-249-9, "Additional Material for Subsection NF, Classes 1, 2, 3 and MC Component Supports Fabricated Without Welding, Section III, Division 1."

Code Case N-284, "Metal Containment Shell Buckling Design Mrthods Section III, Division 1, Class MC."

Code Case N-309-1, "Identification of Materials for Component Supports, Section III, Division 1."

Code Case N-313, "Alternate Rules for Half-Coupling Branch Connections, Section III, Division 1."

Code Case N-316, "Alternate Rules for Fillet Weld Dimensions for Socket Welded Fittings, Section III, Division 1, Class 1, 2, 3."

Code Case N-318-3, "Procedure for Evaluation of the Design of Rectangular Cross Section Attachments on Class 2 or 3 Piping, Section III, Division 1."

Code Case N-319, "Alternate Procedure for Evaluation of Stress in Butt Weld Elbows in Class 1 Piping, Section III, Division 1."

Code Case N-391, "Procedure for Evaluation of the Design of Hollow Circular Cross Section Welded Attachments on Class 1 Piping, Section III, Division 1."

Code Case N-392, "Procedure for Evaluation of the Design of Hollow Circular Cross Section Welded Attachments on Classes 2 and 3 Piping, Section III, Division 1."

Code Case N-393, "Repair Welding Structural Steel Rolled Shaped and Plates for Component Supports, Section III, Division 1."

Code Case N-411, "Alternative Damping Values for Response Spectra Analysis of Classes 1, 2, and 3 Piping, Section III, Division 1."

Code Case N-411-1, "Alternative Damping Values for Response Specific Analysis of Class 1, 2, and 3 piping Section III, Division 1."
Code Case N-414, "Tack Welds for Class 1, 2, 3 and MC Components and Piping Supports."

Code Case N-420, "Linear Energy Absorbing Supports for Subsection NF, Classes 1, 2, and 3 Construction, Section III, Division 1," New York.

Code Case N-430, "Requirements for Welding Workmanship and Visual Acceptance Criteria for Class 1, 2, 3 and MC Linear-Type and Standard Supports."

Code Case N-476, Supplement 1, May 1989, "Class 1, 2, 3, and MC Linear Component Supports - Design Criteria for Single Angle Members, Section III, Division 1, Subsection NF," New York.

Section II, "Material Specifications."

Section III, "Nuclear Power Plant Components."

Section XI, "Inservice Inspection"

Battelle Memorial Institute, BMI-1863, "Fission Product Deposition and Its Enhancement Under Reactor Accident Condition: Deposition on Primary System Surfaces," J.M. Genco et al., May 1969.

\section{Bechtel Power Corporation}

Bechtel Topical Report (BC-TOP), BC-TOP-1, "Containment Building Liner Plate Design Report," Revision 1.

BC-TOP-3, "Tornado and Extreme Wind Design Criteria for Nuclear Power Plants, " Revision 3, August 1974.

BC-TOP-4A, "Seismic Analysis of Structures and Equipment for Nuclear Power Plants"

(Proprietary) Design Guide C.2.44, Revision 0, August 1980 (revision of Bechtel Topical Report No. BC-

TOP-4A, Revision 3, "Seismic Analysis of Structures and Equipment for Nuclear Power Plants," San Francisco, CA, November 1974).

\section{Conference Proceedings}

Soydemir, C., "Seismic Design of Rigid Underground Walls in New England," Proceedings of the 2nd International Conference on Recent Advances in Geotechnical Earthquake Engineering and Soil Dynamics, St. Louis, MO, March 11-15, 1991. 
Chang, C.Y., ot al., "Analysis of Dynamic Lateral Earth Pressures Recorded on Lotung Reactor Containment Model Structure," Proceedings of the 4th U.S. National Conference on Earthquake Engineering, Palm Springs, CA, May 20-24, 1990.

Seed, H.B., and R.V. Whitman, "Design of Earth Retaining Structures for Dynamic Losds, "Proceedings of the ASCE Specialty Conference on Lateral Stresses in the Ground and Design of Earth Retaining Structures, Cornell University, Ithaca, NY 1970.

Whitman, R.V., "Seismic Design and Behavior of Gravity Retaining Walls," Proceedings of the ASCE Conference on Design and Performance of Earth Retaining Structures, Comell University, Ithaca, NY, 1990.

Whitman, R.V., "Seismic Design of Earth Retaining Structures," Proceedings of the Second International Conference on Recent Advances in Geotechnical Earthquake Engineering and Soil Dynamics, St. Louis, MO, March 11-15, 1991.

Wood, J.H., "Earthquake-Induced Soil Pressures on Structures," Report No. EERL 73-05, Earthquake Engineering Research Laboratory, California Institute of Technology, Pasadena, CA, August 1973.

\section{Crane Manufacturers Association of American, 70}

Crane Co. Technical Paper 410, 1973, "Flow of Fluids Through Valves, Fittings, and Pipe."

Electrical Manufacturers Association, 18th DOE Nuclear Airborne Waste Management and Air Cleaning Conference, "Fittings and Supports for Conduit and Cable Assemblies,"

\section{Electric Power Research Institute}

"Advanced Light Water Reactor Utility Requirements Document," Volumes I, II, and III, December 1992, Palo Alto, Califormia.

NP-3589-SR-LD, "Boiling Water Reactor (BWR) Water Chemistry Guidelines," April 1985.

NP-4947-SR, "BWR Hydrogen' Water Chemistry Guidelines: 1987 Revision," October 1988.

NP-4947-SR, "BWR Hydrogen Water Chemistry Guidelines: 1987 Revision," December 1988.
NP-5283-SR-A, "Guidelines for Permanent BWR Hydrogen Water Chemistry Installations," September 1987.

NP-5526, V "Radwaste Generation Survey," (Volume 1).

NP-5639, "Guidelines for Piping System Reconciliation (NCIG-05, Rev. 1)," May 1988.

NP-5769, "Degradation and Failure of Bolting in Nuclear Power Plants," April 1988.

NP-5930, "A Criterion for Determining Exceedance of the Operating Basis Earthquake," July 1988.

NP-6695, "Guidelines for Nuclear Plant Response to an Earthquake," December 1989.

TR-100082, "Standardization of the Cumulative Absolute Velocity," December 1991.

\section{GE Nuclear Energy}

"ABWR SSAR Main Steam, Feedwater and SRVDL Piping Systems Design Criteria and Analysis Methods (draft)," Revision 0, February 1992.

"Advanced Reactor Programs - ABWR Control Room Design" - presented to the United States Nuclear Regulatory Commission, M.A. Ross (GE), (proprietary) April 3 and 4, 1992, Tokyo, Japan.

ATWS Stability study, February 19, 1993, GE transmitted by letter, February 22, 1993.

"Plain Carbon Steel Data Book," GE-408HA414, Revision 1, September 7, 1981, San Jose, California.

"Probability of Missile Generation in General Electric Nuclear Turbines," (proprietary) January 1984.

NE-123-E070-0493, "Sample Analysis for the Effects of Post:lated Pipe Break, ABWR Main Steam Piping," San Jose, California.

NEDC-31858P, "BWROG Report for Increasing MSIV Leakage Rate Limits and Elimination of Leakage Control System," February 1991.

NEDE-20566-A, "General Electric Company Analytical Model for Loss-of-Coolant Accident Analysis in Accordance with 10 CFR Part 50, Appendix K," (Volume 1) September 1986. 
NEDE-21544-P, "Mark II Pressure Suppression Containment Systems: An Analytical Model of the Pool Swell Phenomenon," December 1977.

NEDE-24011-P, "General Electric Standard Application for Reactor Fuel" (GESTAR II) (proprietary).

NEDE-24222, "Assessment of BWR Mitigation of ATWS," December 1979.

NEDE-24326-1-P, "General Electric Environmental Qualification Program," August 1982, (Supplement 1) (proprietary) January 1983.

NEDE-25205, "Piping Systems Design Criteria and Analysis Methods," Supplement 1, March 1981, San Jose, California.

NEDE-30996P-A, "SAFER Model for Evaluation of Loss-of-Coolant Accidents fer Jet Pump and Non-Jet Pump Plants," Volumes I and II, October 1987.

NEDE-31096-A, "GE Licensing Topical Report, ATWS Response to NRC ATWS Rule, 10 CFR 50.62," February 1987.

NEDE-31152P, "General Electric Fuel Bundle Designs Evaluated with GESTAR-Mechanical Analysis Bases" (proprietary), (Rev. 10), December 1988.

NEDO-10751, "Experimental and Operation Confirmation of Offgas System Design Parameters".

NEDO-10802-A, "Analytical Methods of Plant Transient Evaluations for the General Electric Boiling Water Reactor," (AM. 1) (AM. 2) December 1986.

NEDO-11209, " Quality Assurance Program Description," Revision 7, May 1987.

NEDO-20533, "The GE Mark III Pressure Suppression Containment Analytical Model," June 1974, ISupplement 1) September 1975 .

NEDO-21061, Revision 0, November 1975

NEDO-22155, "Generation and Mitigation of Combustible Gas Mixtures in Inerted BWR Mark I Containment," June 1982.

NEDO-24154 and 24154-P, "Qualification of the OneDimensional Core Transient Model for Boiling Water Rectors, (Volumes 1, 2 and 3 (proprietary)) October 1978.
NEDO-24708, "Additional Information Required for NRC Staff Generic Report on Boiling Water Reactors," August 1979.

NEDO-31643P, "Increasing Main Steam Isolation Valve Leakage Rate Limits and Eliminating Leakage Control Systems," November 1988.

NEDO-31960, "BWR Owner's Group Long-Term Stability Solutions Licensing Methodology," June 1991.

Heat Exchanger Institute, "Standards for Steam Surface Condensers," 6th Edition (1970).

Idaho Nuclear/National Reactor Testing Station (IN)1394, "Deposition of lodine 131 in CDE Experiments," Nebeker et al., 1989.

\section{Instrument Society of America}

ISA-S67.02 (1980), "Nuclear-Safety-Related Instrument Sensing Line Piping and Tubing Standards for Use in Nuclear Power Plants."

S67.04-1982, "Setpoints for Nuclear Safety-Related Instrumentation Used In Power Plants."

International Commission on Radiation Protection, Publication 30 (ICRP-30)

International Conference of Building Officials, "Uniform Building Code (UBC)," 1991, Whittier, California.

\section{International Electrotechnical Commission}

IEC 880-1986, "Software for Computers in the Safety Systems of Nuclear Power Stations."

EIC 801-2, "Electromagnetic Caparability for IndustrialProcess Measurement and Control Equipment, Part 2: Electrostatic Discharge Requirements."

International Standard Organization (ISO) 7498 (1984), "Open Systems Interconnection - Basic Reference Model."

LaSalle test report on FMCRD in-plant test program by letter, October 12, 1989. 


\section{National Fire Protection Association}

"Recommendations Practice for Smoke Control Systems."

10, "Portable Fire Extinguishers - Installation."

10A, "Portable Fire Exinguishers - "Maintenance and Use."

11, "Foam Extinguishing System."

13, "Sprinkler Systems."

14, "Standpipe and Hoe Systems."

15, "Water Spray Fixed Systems."

16, "Deluge Foam - Water Sprinkler Systems."

16A, "Closed Head Foam - Water Spinkler Systems."

20, "Certified Fire Pump - Installation.

24, "Outside Protection."

78, "Lightning Protection Code."

National Oceanic and Atmospheric Administration

Hydrometeorological Report No. 51, "Probable Maximum Precipitation Estimates, United States East of the 105th Meridian," U.S. Department of Commerce, June 1978.

Hydrometeorological Report No. 52, "Application of Probable Maximum Precipitation Estimates - United States East of the 105th Meridian," U.S. Department of Commerce, August 1982.

Nuclear Energy Property Insurance Association, "Basic Fire Protection for Nuclear Power Plants."

\section{Nuclear Utilities Management and Resources Council}

NUMARC 91-06, "Guidelines for Industry Actions to Assess Shutdown Management," December 1991.

NUMARC 93-01, "Industry Guideline for Monitoring the Effectiveness of Maintenance at Nuclear Power Plants," May 1993.
Nuclear Safety Analysis Center, NSAC-88, "Residual Heat Removal Experience Review and Safety Analysis

- Boiling Water Reactor."

U.S. Army Corps of Engineers Technical Report ITL-92-11, "The Seismic Design of Waterfront

Retaining Structures," Vicksburg, MS, November 1992.

\section{U.S. Atomic Energy Commission}

WASH-1300, "Technical Basis for Interim Regional Tornado Criteria," 1.974.

WASH-1400 (NUREG-75/014), "Reactor Safety Study, An Assessment of Accident Risks in U.S. Commercial Nuclear Power Plants," October 1975.

Technical Information Document (TID), TID-14844, "Calculation of Distance Factors for Power and Test Reactor Sites," March 23, 1962.

\section{U.S. Department of Defense}

MPL C71-4010 (Rev. 0, May 18, 1990), "Reactor Protection System, Hardware/Software System Specification."

MPL ABBE-4080 (Rev. 0, April 25, 1990), "EMS/SSLC Interface Requirements, Requirements Specification."

MIL-STD-461C (1987), "Electromagnetic Emission and Susceptibility Requirements for the Control of Electromagnetic Interference."

MPL A32-4080 (Rev. 1, April 24, 1990), "Safety System Logic and Control Design Specification."

Standard 2167A-1988, "Defense System Software Development."

MIL-HDBK-251, "Reliability/Design: Thermal Applications."

MIL-HDBK-217, "Reliability of Electronic Components."

MIL-STD-462 (1987), "Measurement of Electromagnetic Interference Characteristics."

MPL A11-4121 (Rev. a (preliminary), January 19, 1988), "Multiplexing System Application Procedure, Design Procedure." 
MPL DMH-4270 (Rev. 2, February 3, 1989), "Essential Multiplexing System Design Specification."

U.S. Army Technical Manual (TM), 5-855-1, "Fundamentals of Protective Design (Non-Nuclear)," November 1986.

MPL A32-4080 (Rev. 0, April 25, 1990), "EMS/SSLC Interface Requirements, Requirements Specification."

MPL C71-5030 (Rev. 0, April 23, 1990), "Reactor Protection System Verification and Validation Criteria Design Specification."

DOD-CTD-2167, "Military Standard - Defense System Software Development," June 1985.

MPL C71-4010 (Rev. 1, July 2, 1990), "Reactor

Protection System Design Specification."

\section{U. S. Nuclear Regulatory Commissiop}

\section{Bulletins}

79-08, "Events Relevent to Boiling Water Power Reactors Identified During Three Mile Island Incident," April 14, 1979.

79-02, "Pipe Support Gas Plate Designs Using Concrete Expansion Anchor Bolts," (Rev. 1) June 21, 1979.

80-20, "Failures of Westinghouse Type W-2 Spring Return to Neutral Control Switches," July 31, 1980.

80-01, "Operability of ADS Valve Pneumatic Supply," January 11, 1980.

80-03, "Loss of Charcoal From Standard Type II, 2 Inch, Tray Adsorber Cells," February 6, 1980.

80-06, "Engineered Safety Feature (ESF) Reset Controls," March 13, 1980.

80-10, "Contamination of Nonradioactive System and Resulting Potential for Unmonitored, Uncontrolled Release of Radioactivity to Environment," May 6, 1980.

81-02, "Failure of Gate Type Valves to Close Against Differential Pressure," April 9, 1981.

82-04, "Deficiencies in Primary Containment Electrical Penetration Assemblies," December 3, 1982.
88-07, "Power Oscillations in Boiling Water Reactors (BWRs)," June 15, 1988.

88-03, "Thermal Stresses in Piping Connected to Reactor Coolant Systems, " June 22, 1988, (Supplement 1) June 24, 1988, (Supplem:nt 2) August 4, 1988, (Supplement 3) April 11, 1989.

90-01, "Loss of Fill-Oil in Transmitters Manufactured by Rosemount," March 9, 1990, (Supplement 1) December 22, 1992.

91-01, "Reporting Loss of Criticality Safety Controls," October 18, 1991.

93-02, "Debris Plugging of Emergency Core Cooling Suction Strainers," May 11, 1993.

93-03, "Resclution of Issues Related to R'sactor Vessel Water Level Insirumentation in Bứks, " May 28, 1993.

\section{Generic Letters}

80-03, "Clarification of the Term "Operable" as it Applies to Single Failure Criterion for Safety Systems Required by TS," April 10, 1980.

81-38, NRC Letter to All Holders of and Applicants for Operating Licenses and Construction Permits, "Storage of Low-Level Radioactive Wastes at Power Reactor Sites (81-38)" November 10, 1981.

83-27, NRC Letter to All Licensees and Applicants for Operating Power Reactors and Holders of Construction Permits for Power Reactors, "Surveillance Intervals in

Standard Technical Specifications (83-27), " July 6, 1983.

83-28, NRC Letter to All Licensees of Operating Reactors, Applicants for Operating License, and Holders of Construction Permits, "Required Actions Based on Generic Implications of Salem ATWS Event, (No. 83-28)," July 8, 1983.

84-15, NRC Letter to All Licensees of Operating Reactors, Applicants for An Operating License, and Holders of Construction Permits, "Proposed Staff Actions to Improve and Maintain Diesel Generator Reliability (84-15)," July 2, 1984. 
85-23, NRC Letter to All Boiling Water Reactor Licensees of Operating Reactors Except LaCrosse, Big Rock Point, Humbolot Bay and Dresden -1, "Reactor Vessel Water Level Instrumentation in BWRs (84-23)," October 26, 1984.

88-02, NRC Letter to All Power Reactor Licensees, "Integrated Safety Assessment Program II (ISAP II) (8802), " January 20, 1988.

88-17, NRC Letter to All Holders of Operating Licensees or Construction Permits for Pressurized Water Reactors, "Loss of Heat Decay Removal (No. 88-17) 10 CFR 50.54(f)," October 14, 1988.

88-20, NRC Letter to All Licensees Holding Operating Licensees and Construction Permits for Nuclear Power Reactor Facilities, "Individual Plant Examination for Severe Accident Vulnerabilities - 10 CFR 50.54(f) (No. 88-20), " November 23, 1988.

89-01, NRC Letter to All Power Reactor Licensees and Applicants, "Implementation of Programmatic Controls for Radiological Effluent Technical Specifications in the Administrative Controls Section of the Technical Specifications and the Relocating of Procedure Details of RETS to the Offsite Done Calculation Manual or to the Process Control Program (89-01)," January 3, 1989.

89-04, NRC Letter to All Holders of Light Water Reactor Operating Licensees and Construction Permits "Guidance on Developing Acceptable Inservice Testing Programs (No. 89-04)," April 3, 1989.

89-08, NRC Letter to All Holders of Operating Licensees or Construction Permits for Nuclear Power Plants, "Erosion/Corrosion-Induced Pipe Wall Thinning (89-08), "May 2, 1989.

89-10, NRC Letter to All Licensees of Operating Nuclear Power Plants and Holders of Construction Permits for Nuclear Power Plants, "Safety-Related Motor-Operated Valve Testing and Surveillance (No. 89-10) - 10 CFR 50.54(f)," June 28, 1989, (Supplement 1) June 13, 1990, (Supplement 2) August 3, 1990, (Supplement 3) October 25, 1990, (Supplement 4) February 12, 1992, (Supplement 5) June 28, 1993, (Supplement 6) March 1994.

89-14, NRC Letter to All Licensees of Operating Plant, Applicants for Operating Licensees, and Holders of Constructions Permits, "Line-Item Improvements in Technical Specifications - Removal of 3.25 Limit on Extending Surveillance Intervals (89-14), "August 21, 1989.
89-16, NRC Letter to All Holders of Operating Licenses for Nuclear Power Reactors with Mark I Containments, "Installation of A Hardened Wetwell Vent (89-16)," September 1, 1989.

89-18, NRC Letter to All Holders of Operating Licenses or Construction Permits for Nuclear Power Plants, "Resolution of Unresolved Safety Issue A-17, 'Systems Interactions in Nuclear Power Plants' (89-18)," September 6, 1989.

89-19, NRC Letter to All Licensees of Operating Reactors, Applicants for Operating, Licenses and Holders of Construction Permits for Light Water Reactor Nuclear Power Plants, "Request for Action Related to Resolution of Unresolved Safety Issue A-47, 'Safety Implication of Control Systems in LWR Nuclear Power Plants' Pursuant to 10 CFR 50.54(f) - 89-19,'" September 20, 1989.

89-22, NRC Letter to All Licensees of Operating Reactors and Holders of Construction Permits, "Potential for Increased Roof Loads and Plant Area Flood Runoff Depth at Licensed Nuclear Plants Due to Recent Change in Probable Maximum Precipitation Criteria Developed by the National Weather Service (89-22), " October 19, 1989.

91-04, NRC Letter to All Holders of Operating Licenses or Construction Permits for Nuclear Power Reactors, "Changes in Technical Specification Surveillance Intervals to Accommodate a 24-Month Fuel Cycle (9104)," April 2, 1991.

91-09, NRC Letter to All Holders of Operating Licenses for Boiling-Water Reactors "Modification of Surveillance

Interval for the Electrical Protective Assemblies in Power Supplies for the Reactor Protection System (91-09)," June 27, 1991.

91-13, NRC Letter to Licensees and Applicants of the Following Pressurized-Water Reactor Nuclear Power Plants: (1) Braidwood Units 1 and 2; (2) Byron Units 1 and 2; (3) Catawba Units 1 and 2; (4) Comanche Peak Units 1 and 2; (5) Cook Units 1 and 2; (6) Diablo Canyon Units 1 and 2; (7) McGuire Units 1 and 2, "Request for Information Related to the Resolution of Generic Issue 130, 'Essential Service Water System Failures at Multi-Unit Sites,' Pursuant to 10 CFR 50.54(f) - 91-13," September 19, 1991. 
91-17, NRC Letter to All Holders of Operating Licenses or Construction Permits for Nuclear Power Plants, "Generic Safety Issue 29, 'Bolting Degradation of Failure in Nuclear Power Plants', (91-17)," October 17, 1991.

92-04, NRC Letter to All Boiling Water Reactor Licensees of Operating Resctors, "Resolution of the Issues Related to Reector Veesel Water Lovel Instrumentation in BWRs Pursuent to 10 CFR 50.54(f) (No. 92-04)," August 19, 1992.

\section{Insormation Notices}

79-22, "Qualification of Control Systems," September 14, 1979.

83-83, "Use of Portable Radio Transmitters Insido Nuclear Power Plants," December 19, 1983.

83-41, "Actuation of Fire Suppression System Causing Inoperability of Safoty-Related Equipment," June 22, 1983.

84-87, "Piping Thermal Deflection Induced by Stratified Flow," December 8, 1984.

86-64, "Deficiencies in Upgrade Programs for Plant Emergency Operating Procedures," August 14, 1986, (Supplement 1) April 20, 1987.

86-106, "Feedwater Line Break," December 16, 1986, (Sunplement 1) February 13, 1987, (Supplement 2) March 1987.

89-63, "Possible Submergence of Electrical Circuits Located Above the Flood Level Because of Water Intrusion and Lack of Drainage, "September S, 1989.

91-38, "Thermal Stratification in Feedwater System Piping," June 13, 1991.

92-54, "Level Instrumentation Inaccuracies Caused by Rapid Depressurization," July 24, 1992.

92-71, "Partial Plugging of Suppression Pool Strainers at a Foreign BWR," September 30, 1992.

93-34, "Potential for Loss of Emergency Cooling Function Due to a Combination of Operational and PostLOCA Debris in Containment," April 26, 1993, (Supplement 1) May 6, 1993.

\section{Commisston Papers}

SECY-83-248, "Generic Actions for Licensees and Staff in Response to the ATWS Events at Salem Unit 1," June $27,1983$.

SECY-88-147, "Integration Plan for Closure of Severe Accident Issues," May 25, 1988.

SECY-89-012, "Staff Plans for Accident Management Regulatory and Research Programs," January 18, 1989.

SECY-89-013, "Design Requirements Related to the Evolutionary Advanced Light Water Reactors (ALWRs)," January 19, 1989.

SECY-89-153, "Sovere Accident Design Features of the Advanced Boiling Water Reactor (ABWR)," May 10, 1989.

SECY-89-230, "Unresolved Safety Issue A-17, 'Systems Interactions in Nuclear Power Plants'," August 1, 1989.

SECY-90-016, "Evolutionary Light Water Reactor (LWR) Cortification Issues and Their Relationship to Current Regulatory Requirements," January 12, 1990.

SECY-90-241, "Level of Detail Required for Design Certification Under Part 52," July 11, 1990. The Commission's guidance on this SECY was provided in an SRM dated August 22, 1990.

SECY-90-313, "Status of Accident Management Program and Plans for Implementation," September 5, 1990.

SECY-90-329, "Comparison of the General Electric Advanced Boiling Water Reactor (ABWR) Design and the Electric Power Research Institute's (EPRI's) Advanced Light Water Reactor (ALWR) Requirements Document," September 20, 1990.

SECY-90-377, "Requirements for Design Certification Under 10 CFR Part 52," November 8, 1990. The Commission's guidance on this SECY was provided in an SRM dated February 15, 1991.

SECY-91-078, "Chapter 11 of the Electric Power Research Institute's (EPRI's) Requirements Document and Additional Evolutionary Light Water Reactor (LWR) Certification Issues," March 25, 1991. The Commission's guidance on this SECY was provided in SRMs dated April 1 and August 15, 1991. 
SECY-91-135, "Conclusions of the Probabilistic Seismic Hazard Studies Conducted for Nuclear Power Plants in the Eastern United States," May 14, 1991.

SECY-91-153, "Draft Safety Evaluation Report on General Electric Company Advanced Boiling Water Reactor Design Covering Chapters 1, 2, 3, 4, 5, 6, and 17 of the Standard Safety Analysis Report," May 24, 1991.

SECY-91-178, "Inspections, Tests, Analyses, and Acceptance Criteria (ITAAC) for Design Certifications and Combined Licenses," June 12, 1991. The Commission's guidance on this SECY was provided in an SRM dated September 24, 1991.

SECY-91-210, "Inspections, Tests, Analyses, and Acceptance Criteria (ITAAC) Requirements for Design Review and Issuance of a Final Design Approval (FDA)," July 16, 1991. The Commission's guidance on this SECY was provided in an SRM dated October 18, 1991.

SECY-91-229, "Severe Accident Mitigation Design Alternatives for Certified Standard Designs," July 31, 1991. The Commission's guidance on this SECY was provided in an SRM dated October 25, 1991.

SECY-91-235, "Draft Safety Evaluation Report on the General Electric Boiling Water Reactor Design Covoring Chapters 1, 3, 9, 10, 11, and 13 of the Standard Safety Analysis Report," August 2, 1991.

SECY-91-262, "Resolution of Selected Technical and Severe Accident Issues for Evolutionary Light Water Reactor (LWR) Designs," August 16, 1991. The Commission's guidance on this SECY was provided in an SRM dated January 28, 1992.

SECY-91-272, "Role of Personnel and Advanced Control Rooms in Future Nizclear Power Plants, " August 27, 1991.

SECY-91-292, "Digital Computer Systems for Advanced Light Water Reactors," September 16, 1991.

SECY-91-294, "Draft Safety Evaluation Report on the General Electric Boiling Water Reactor Design Covering Chapter 7 of the Standard Safety Analysis Report," September 18, 1991.
SECY-91-309, "Draft Safety Evaluation Report on the General Electric Boiling Water Reactor Design Covering Chapter 19 of the Standard Safety Analysis Report," 'Response to Severe Accident Policy Statement'," October 1, 1991.

SECY-91-320, "Draft Safety Evaluation Report on the General Electric Advanced Boiling Water Reactor Design Covering Chapter 18 of the Standard Safety Analysis Report," October 15, 1991.

SECY-91-348, "Isounce of Final Revision to Appendix $\mathrm{J}$ to 10 CFR Part 50, and Related Final Regulatory Guide 1.XXX (MS 021-5)," October 25, 1991.

SECY-91-355, "Draft Safoty Evaluation Report on the General Electric Boiling Water Reactor Design Covering Chapters 1, 2, 3, 5, 6, 8, 9, 10, 12, 13, 14, and 15 of the Standard Safety Analysis Report," October 31, 1991.

SECY-92-053, "Use of Design Acceptance Criteria During 10 CFR Part 52 Design Certification Reviews," February 19, 1992.

SECY-92-092, "The Containment Performance Goal, External Events Sequences, and the Definition of Containment Failure for Advanced Light Water Reactors," March 17, 1992.

SECY-92-134, "NRC Construction Inspection Program for Evolutionary and Advanced Reactors Under 10 CFR Part 52," April 15, 1992.

SECY-92-196, "Development of Design Acceptance Criteria (DAC) for the Advanced Boiling Water Reactor (ABWR)," May 28, 1992.

SECY-92-214, "Development of Inspections, Tests, Analyses, and Acceptance Criteria (ITAAC) for Design Certifications," June 11, 1992.

SECY-92-287, "Form and Content for a Design Certification Rule," August 18, 1992. The Commission's guidance on this SECY was provided in an SRM dated June 23, 1993.

SECY-92-287A, "Form and Content for a Design Certification Rule," dated March 26, 1993. The Commission's guidance on this SECY was provided in an SRM dated June 23, 1993. 
SECY-92-299, "Development of Design Acceptance Criteria (DAC) for the Advanced Boiling Water Reactor (ABWR) in the Areas of Instrumentation and Controls (I\&C) and Control Room Design," August 27, 1992.

SECY-92-327, "Review of Inspections, Tests, Analyses, and Acceptance Criteria (ITAAC) for the General Electric (GE) Advanced Boiling Water Reactor (ABWR)," September 22, 1992.

SECY-92-381, "Rulemaking Procedures for Design Certification," November 10, 1992. The Commission's guidance on this SECY was provided in an SRM dated April 30, 1993.

SECY-92-349, "Draft Final Safety Evaluation Report on the GE Nuclear Energy (GE) Boiling Water Reactor (ABWR) Standard Safety Analysis Report (SSAR) for Design Certification," October 14, 1992.

SECY-93-041, "Advanced Boiling Water Reactor (ABWR) Review Schedule," February 18, 1993.

SECY-93-087, "Policy, Technical, and Licensing Issues Pertaining to Evolutionary and Advanced Light-Water Reactor Designs," April 2, 1993. The Commission's guidance on this SECY was provided in an SRM dated July 21, 1993.

SECY-93-097, "Integrated Review Schedules for the Evolutionary and Advanced Light Water Reactor Projects," dated April 14, 1993. The Commission's guidance on this SECY was provided in an SRM dated June 24, 1993.

SECY-93-190, "Regulatory Approach To Shutdown and Low-Power Operations," July 12, 1993.

SECY-94-084, "Policy and Technical Issues Associated with the Regulatory Treatment of Non-Safety Systems in Passive Plant Designs," March 28, 1994.

\section{Policy Statements}

Final Policy Statement on Technical Specifications Improvements for Nuclear Power Reactors, 58 FR 39132, July 22, 1993.

"Commission Policy Statement on Technical Specifications Improvements for Nuclear Power Plants," 52 FR 3788, February 6, 1987.
Policy Statement on Severe Reactor Accidents Regarding Future Designs and Existing Plants, 50 FR 32138, Policy Statement, "Conversion to the Metric System," 57 FR 46202, October 7, 1992.

Policy Statement, "Nuclear Power Plant Standardization," 52 FR 34884, September 15, 1987.

Policy Statement, "Safety Goals for the Operations of Nuclear Power Plants," 51 FR 28044, August 4, 1986.

\section{Regulations}

Title 10 of the Code of Federal Regulations (CFR) "Energy."

Advanced Notice of Proposed Rulemaking, "Rulemakings to Grant Standard Design Certification for Evolutionary Light Water Reactor Designs," 58 FR 58664, November 3, 1993.

\section{Regulatory Guides}

1.1, "Net Positive Suction Head for Emergency Core Cooling and Containment Heat Removal System Pumps (Safety Guide 1)," (Rev. 0), November 1970.

1.100, "Seismic Qualification of Electric and Mechanical Equipment for Nuclear Power Plants," (Rev. 2) June 1988.

1.105, "Instrument Setpoints for Safety-Related Systems," (Rev. 2) February 1986.

1.106, "Thermal Overload Protection for Electric Motors on Motor-Operated Valves, " November 1975, (Rev. 1) March 1977.

1.108, "Periodic Testing of Diesel Generator Units Used as Onsite Electric Power Systems at Nuclear Power Plants," August 1976, (Rev. 1) August 1977.

1.109, "Calculation of Annual Doses to Man from Routine Releases of Reactor Effluents for the Purpose of Evaluating Compliance with 10 CFR Part 50, Appendix I," March 1976, (Rev. 1) October 1977.

1.111, "Methods for Estimating Atmospheric Transport and Dispersion of Gaseous Effluents in Routine Releases From Light-Water-Cooled Reactors, (Rev. 1) July 1977. 
1.112, "Calculation of Releases of Radionctive Materials in Gaseous and Liquid Effluents from Light-WaterCooled Power Reectors," (Rev. 0) April 1976.

1.114, "Guidance on Being Operator at the Controls of a Nuclaar Power Plant," February 1976, (Rev. 1)

November 1976.

1.115, "Protection Against Low-Trajectory Turbine Missiles," (Rev. 1) July 1977.

1.117, "Tornado Design Classification," (Rov. 1) April 1978.

1.118, "Periodic Testing of Electric Power and Protection Systems," June 1976, (Rev. 1) November 1977, (Rev. 2) June 1978.

1.i ?, "Instrumentation for Earthquakes," U.S NRC March 1971, (Rev. 1) April 1974( DG-1033, third proposed Revision 2).

1.122, "Development of Floor Design Response Spectra for Seismic Design of Floor-Supported Equipment or Components," (Rev. 1) February 1978.

1.124, "Service Limits and Loading Combinations for Class 1 Linear-Type Component Supports," (Rev. 1) January 1978.

1.13, "Spent Fuel Storage Facility Design Basis (for comment)," March 1971, (Rev. 1) December 1975.

1.133, "Loose-Part Detection Program for the Primary System of Light-Water Cooled Reactor," September 1977, (Rev. 1) May 1981.

1.136, "Materials, Construction, and Testing of Concrete Containments Articles cc-1000, -2000 AND 4000 through -6000 of the Code for Concrete Reactor Vessels and Containments," (Rev. 2) June 1981.

1.137, "Fuel-Oil Systems for Standby Diesel Generators," January 1978, (Rev. 1) October 1979.

1.139, "Guidance for Residual Heat Removal (for comment)," May 1978.

1.140, "Design, Testing, and Maintenance Criteria for Normal Ventilation Exhaust System Air Filtration and Adsorption Units of Light-Water-Cooled Nuclear Power Plants," March 1978, (Rev. 1) October 1979.

1.141, "Containment Isolation Provisions for Fluid Systems, (for comment)" (Rev. 0) April 1978.
1.142, "Safety-Related Concrete Structures for Nuclear Power Plants (Other than Reactor Vessels and Containments), (Rov. 1) October 1981.

1.143, "Design Guidance for Radioactive Waste Management Systems, Structures, and Components Installed in Light-Water-Cooled Nuclear Power Plants," (Rev. 1) October 1979.

1.145, "Atmospheric Dispersion Models for Potential Accident Consequence Assessment at Nuclear Power Plants," (Rev. 1) November 1982.

1.147, "Inservice Inspection Code Case Acceptability ASME Section XI, Division 1," (Rev. 10) July 1993.

1.150, "Ultrasonic Testing of Ruactor Vessel Welds During Preservice and Inservice Examinations (Draft SC 705-4 published May 1979)," (Rev. 1) February 1983.

1.151, "Instrument Sensing Lines (Draft IC 126-5 published March 1982)," July 1983.

1.152, "Criteria for Programmable Digital Computer System Software in Safety-Related Systems of Nuclear Power Plants (Draft IC 127-5 published March 1983)," November 1985.

1.153, "Criteria for Power, Instrumentation, and Control Portions of Safety Systems (Draft IC 609-5 published December 1982)," (Rev. 0) December 1985.

1.155, "Station Blackout (Draft SI 501-4 published March 1986)," (Rev. 0) August 1988.

1.160, "Monitoring the Effectiveness of Maintenance at Nuclear Power Plants (Draft DG-1020 published November 1992)," June 1993.

1.20, "Comprehensive Vibration Assessment Program for Reactor Internals During Preoperational and Initial Startup Testing," (Rev. 2), May 1976.

1.21, "Measuring, Evaluating, and Reporting Redioactivity in Solid Wastes and Releases of Radioactive Materials in Liquid and Gaseous Effluents from Light-Water-Cooled Nuclear Power Plants," December 1971, (Rey. 1) June 1974.

1.22, "Periodic Testing of Protection System Actuation Function (Safety Guide 22)," February 1972.

1.23, "Onsite Meteorological Programs (Safety Guide 23)," (Rev. 0), February 1972. 
1.26, "Quality Group Classifications and Standards for Wator-, Steam-, and Radioactivo-Wasto-Containing Components of Nuclear Power Plants (for comment)," (Rev. 3) Fobruary 1976.

1.27, "Ultimato Heat Sink for Nuclear Power Plants (for comment)," March 1972, (Rev. 1) March 1974, (Rev. 2) January 1976.

1.29, "Seismic Design Classification," June 1972, (Rev. 1) August 1973, (Rev. 2) February 1976, (Rev. 3) September 1978.

1.3, "Assumptions Used for Evaluating the Potential Radiological Consequences of a Loss of Coolant Accident for Boiling Water Reactors," November 1970, (Rev. 1) June 1973, (Rev. 2) June 1974.

1.31, "Control of Ferrite Content in Stainless Steel Weld Metal," (Rev. 3), April 1978.

1.33, "Quality Assurance Program Requirements (Operation)," (Rev. 2) February 1978.

1.36, "Nonmetallic Thermal Insulation for Austenitic Stainless Steel," (Rev. 0), February 1973.

1.37, "Quality Assurance Requirements for Cleaning of Fluid Systems and Associated Components of WaterCooled Nuclear Plants," March 1973.

1.4, "Assumptions Used for Evaluating the Potential Radiological Consequences of a Loss of Coolant Accident for Pressurized Water Reactors," November 1970, (Rev. 1) June 1973, (Rev. 2) June 1974.

1.43, "Control of Stainless Stool Weld Cladding of Low-Alloy Steel Components," (Rev. 0), May 1973.

1.44, "Control of Sensitized Stainless Steel," (Rev. 0) May 1973.

1.45, "Reactor Coolent Pressure Boundary Leakage Detection Systems," (Rev. 0) May 1973.

1.47, "Bypassed and Inoperable Status Indication for Nuclear Power Plant Safety Systems," May 1973.

1.49, "Power Levels of Nuclear Power Plants," (Rev. 1) December 1973.

1.50, "Control of Preheat Temperature for Welding of Low-Alloy Sterel," (Rev. 0) May 1973.
1.5. "Assumptions Used for Evaluating the Potential Rediological Consequences of a Steam Linc Break Accident for Boiling Water Reactors (Safety Guide 5)," March 1971.

1.52, "Design, Testing, and Maintenance Criteria for Poutaccident Engineered-Safety-Feature Atmosphere Cleanup System Air Filtration and Adsorption Units of Light-Water-Cooled Nuclear Power Plants," June 1973, (Rov. 1) July 1976, (Rev. 2) March 1978.

1.53, "Application of the Single-Failure Criterion to Nuclear Power Plant Protection Systems," June 1973.

1.54, "Quality Assurance Requirements for Protective Contings Applied to Water-Cooled Nuclear Power Plants," June 1973.

1.56, "Maintenance of Water Purity in Boiling Water Reactors," June 1973, (Rev. 1) (for comment) July 1978.

1.57, "Design Limits and Loading Combinations for Metal Primary Reactor Containment System Components," June 1973.

1.57, "Design Limits and Loading Combinations for Metal Primary Reactor Containment System Components," (Rev. 0) May 1989.

1.59, "Design Basis Floods for Nuclear Power Plants," (Rev. 2) August 1977.

1.60, "Design Response Spectra for Seismic Design of Nuclear Power Plants," (Rev. 1) December 1973.

1.61, "Damping Values for Seismic Design of Nuclear Power Plants," (Rev. 0) October 1973.

1.62, "Manual Initiation of Protective Actions," October 1973.

1.63, "Electric Penetration Assemblies in Containment Structures for Nuclear Power Plants," (Rev. 3) February 1987.

1.65, "Materials and Inspections for Reactor Vessel Closure Studs," (Rev. 0) October 1973.

1.68.3, "Preoperational Testing of Instrument and Control Air Systems," April 1982.

1.68, "Initial Test Programs for Water-Cooled Nuclear Power Plants," November 1973, (Rev. 1) January 1977, (Rev. 2) August 1978. 
1.68.1, "Preoperational and Initial Startup Testing of Feedwater and Condensate Systems for Boiling Water Reactor Power Plants," (Rov. 1) January 1977.

1.69, "Concrete Radiation Shields for Nuclear Power Plants, " December 1973.

1.7, "Control of Combustible Gas Concentrations in Containment Following a Loss-of-Coolant Accident," (Rev. 2) November 1978.

1.70, "Standard Format and Content of Safety Analysis Report for Nuclear Power Plants (LWR Edition)," (Rev. 3) November 1978.

1.71, "Welder Qualification for Areas of Limited Accessibility," (Rev. 0) December 1973.

1.72, "Spray Pond Piping Made from FiberglassReinforced Thermosetting Resin," (Rev. 2) November 1978.

1.75, "Physical Independence of Electric Systems," (Rev. 2) September 1978.

1.76, "Design Basis Tornado for Nuclear Power Plants, (Rev. 0) April 1974.

1.77, "Assumptions Used for Evaluating a Control Rod Ejection Accident for Pressurized Water Reactors, " May 1974.

1.78, "Assumptions for Evaluating the Habitability of a Nuclear Power Plant Control Room During a Postulated Hazardous Chemical Release, "June 1974.

1.8, "Qualification and Training of Personnel for Nuclear Power Plants," (Rev. 2) November 1978.

1.82, "Water Sources for Long-Term Recirculation Cooling Following a Loss-of-Coolant Accident, " June 1974, (Rev. 1) November 1985.

1.84, "Design and Fabrication Code Case Acceptability ASME Section III, Division I," (Rev. 25) May 1988.

1.85, "Materials Code Case Acceptability - ASME Section III, Division 1," (Rev. 27) November 1990, (Rev. 28) April 1992.

1.89, "Environmental Qualification of Certain Electric Equipment Important to Safety for Nuclear Power Plants," (Rev. 1) June 1984.
1.9, "Selection, Design, Qualification, and Testing of Emergency Diesel Generator Units Used as Class 1E Onsite Electric Power Systems at Nuclear Power Plants, " March 1971, (Rev. 1) November 1978, (Rev. 2) December 1979, (Rev. 3) July 1993.

1.91, "Evaluations of Explosions Postulated to Occur on Transportation Routes Near Nuclear Power Plants," (Rev. 1) dated February 1978.

1.92. "Combining Modal Responses and Spatial Components in Seismic Response Analysis," (Rev. 1) February 1976.

1.94, "Quality Assurance Requirements for Installation, Inspection, and Testing of Structural Concrete and Structural Steel During the Construction Phase of Nuclear Power Plants," (Rev. 1) February 1976.

1.95, "Protection of Nuclear Power Plant Control Room Operators Against an Accidental Chlorine Release," February 1975, (Rev. 1) January 1977.

1.96, "Design of Main Steam Isolation Valve Leakage Control Systems for Boiling Water Reactor Nuclear Power Plants," (Rev. 1) June 1976.

1.97, "Instrumentation for Light-Water-Cooled Nuclear Power Plants to Assess Plant and Environs Conditions During and Following an Accident, " December 1975, (Rev. 1) August 1977, (Rev. 2) December 1980, (Rev. 3) May 1983.

1.99, "Radiation Embrittlement of Reactor Vessel Materials," (Rev. 2) dated May 1988.

4.15, "Quality Assurance for Radiological Monitoring Programs (Normal Operations)--Effluent Streams and the Environment," December 1977, (Rev. 1) February 1979.

4.7, "General Site Suitability Criteria for Nuclear Power Stations," (Rev. 1) November 1975.

5.12, "General Use of Locks in the Protection and Control of Facilities and Special Nuclear Materials," November 1973.

8.10, "Operating Philosophy for Maintaining Occupational Radiation Exposures As Low As Is Reasonably Achievable," (Rev. 1) September 1975.

8.19, "Occupational Radiation Dose Assessment in Light-Water Reactor Power Plants--Design Stage ManRem Estimate," (Rev. 1) June 1979. 
8.8, "Information Relevant to Ensuring that Occupational Radiation Exposures at Nuclear Power Stations Will Be As Low As Is Reasonably Achievable," (Rev. 3) June 1978.

\section{NUREG Reports}

NUREG-0016, "Calculation of Releases of Radionctive Materials in Gaseous and Liquid Effluents," (Rev. 1) January 1979.

NUREG-0313, "Technical Report on Material Selection and Processing Guidelines for BWR Coolant Pressure Boundary Piping," July 1977, (Rev. 1) July 1980, (Rev. 2) January 1988.

NUREG-0460, "Anticipated Transients Without Scram for Light Water Reactors," (Vol. 1) April 1978, (Vol. 2) April 1978, (Vol. 3) December 1978, (Vol. 4) March 1980.

NUREG-0471, "Generic Task Problem Descriptions (Categories B, C, and D)," June 1978.

NUREG-0484, "Methodology for Combining Dynamic Responses," (Rev. 1) May 1990.

NUREG-0493, "A Defense-in-Depth and Diversity Assescment of the RESAR-414 Integrated Protection System," March 1979.

NUREG-0554, "Single-Failure Proof Cranes for Nuclear Power Plants." May 1979.

NUREG-0578, "TMI-2 Lessons Leamed Task Force Status Report and Short-Term Recommendations," July 1979.

NUREG-0588, "Interim Staff Position on Environmental Qualification of Safety-Related Electrical Equipment," November 1979, (Rev. 1) July 1981.

NUREG-0612, "Control of Heavy Lands at Nuclear Power Plants Resolution of Generic Technical Activity A-36," July 1980.

NUREG-0619, "BWR Feedwater Nozale and Control Rod Drive Return Line Nozzle Cracking," November 1980.

NUREG-0654 (FEMA-REP-1), "Criteria for Preparation and Evaluation of Radiological Emergency Response Plans and Preparedness in Support of Nuclear Power Plants," February 1980, (Rev. 1) November 1980.
NUREG-0660, "NRC Action Plan Developed as a Result of the TMI-2 Accident," May 1980, (Rev. 1) August 1980.

NUREG-0696, "Functional Criteria for Emergency Response Facilities," February 1981.

NUREG-0700, "Guidelines for Control Room Design Review," September 1981.

NUREG-0737, "Clarification of TMI Action Plan Requirements," November 1980, (Supplement 1) January 1983.

NUREG-0775, "Final Environmental Related to the Operation of Steam Comanche Peak, Electric Station Units 1 and 2," (Supplement) October 1989.

NUREG-0783, "Suppression Pool Temperature Limits for BWR Containments for Generic Technical Activity A-39," November 1981.

NUREG-0800, "Standard Review Plan for the Review of Safety Analysis Reports for Nuclear Power Plants," (1st Edition) November 1975, (2nd Edition) March 1980, (3rd Edition) July 1981.

NUREG-0802, "Safety/Relief Valve Quencher Loads: Evaluation for BWR Mark II and III Containments," October 1982.

NUREG-0803, "Generic Safety Evaluation Report Regarding Integrity of BWR Scram System Piping," August 1981.

NUREG-0808, "Mark II Containment Program Evaluation and Acceptance Criteria," August 1981.

NUREG-0933, "A Prioritization of Generic Safety Issues," (with Supplements 1-15), April 1993.

NUREG-0974, "Final Environmental Statement Related to the Generating Station, Units 1 and 2," August 16, 1989.

NUREG-0978, "Mark III LOCA-Related Hydrodynamic Laed Definition," August 1984.

NUREG-0979, "Safety Evaluation Report Related to the Final Design Approval of the GESSAR II BWR/6 Nuclear Island Design," April 1983, (Supplement 1) July 1983, (Supplement 2) November 1984, (Supplement 3) January 1985, (Supplement 4) July 1985, (Supplement 5) May 1986. 
NUREG-1000, "Generic Implications of ATWS Events at the Salem Nuclear Power Plant," (Volume 1) April 1983, (Volume 2) August 1983.

NUREG-1048, "Safety Evaluation Report Related to the Operation of Hope Creek Generating Station," (Supplement 6) July 1986.

NUREG-1061, "Report of the U.S. Nuclear Regulatory Commission Piping Review Committee, Evaluation of Potential for Pipe Breaks," (Vol. 3) November 1984; "Evaluation of Other Dynamic Loads and Load Combinations," (Vol. 4) December 1984.

NUREG-1109, "Regulatory/Backfit Analysis for the Resolution of Unresolved Safety Issue A-44, Station Blackout, " June 1988.

NUREG-1116, "A Review of the Current Understanding of the Potential for Containment Failure From In-Vessel Steam Explosions." June 1985.

NUREG-1174, "Evaluation of Systems Interactions in Nuclear Power Plants," May 1989.

NUREG-1229, "Regulatory Analysis for Resolution of USI A-17," August 1989.

NUREG-1242, "NRC Review of Electric Power Research Institute's Advanced Light Water Reactor Utility Requirements Document" August 1992.

NUREG-1296, "Thermal Overload Protection for Electric Motors on Motor-Operated Valves - Generic Issue II.E.6.1," June 1988.

NUREG-1339, "Resolution of Generic Safety Issue 29: Bolting Degradation or Failure in Nuclear Power Plants," June 1990.

NUREG-1342, "A Status Report Regarding Industry Implementation of Safety Parameter Display Systems, " 1989.

NUREG-1344, "Erosion/Corrosion-Induced Pipe Wall Thinning in U.S. Nuclear Power Plants," April 1989.

NUREG-1367, "Functional Capability of Piping Systems," November 1992.

NUREG-1410, "Loss of Vital ac Power and the Residual Heat Removal System During Mid-Loop Operations at Vogtle Unit 1 on March 20, 1990," June 1990.
NUREG-1433, "Standard Technical Specifications General Electric Plants, BWR/4," September 1992.

NUREG-1434, "Standard Technical Specifications General Electric Plants, BWR/6," September 1992.

NUREG-1449 (Final Report), "Shutdown and Low Power Operation at Commercial Nuclear Power Plants in the United States," September 1993.

NUREG-1449 (Draft), "Shutdown and Low Power Operation at Commercial Nuclear Power Plants in the United States," February 1992.

NUREG-36891, "Effects of Rod Worth and Drop Speed on the BWR Off-Center Rod Drop Accident,"

Brookhaven National Laboratory (BNL).

NUREG/CR-1161, "Recommended Revisions to Nuclear Regulatory Commission Seismic Design Criteria," May 1980.

NUREG/CR-2137, "Realistic Design Margins of Pumps, Valves, and Piping," June 1981.

NUREG/CR-2239, "Technical Guidance for Siting Criteria Development," December 1986.

NUREG/CR-2442, "Reliability Analysis of SteelContainment Strength," June 1982.

NUREG/CR-2713, "Vapor Deposition Velocity Measurement and Consolidation for Iodine and Cesium Iodine," S.L. Nicolosi and P. Baybutt, May 1982.

NUREG/CR-2815, "Probabilistic Safety Analysis Procedures Guide," August 1985.

NUREG/CR-2907, "Radioactive Materials Released from Nuclear Power Plants, " (Annual Reports for 1986 and 1987, Vols. 7 and 8).

NUREG/CR-3190, "Plug - A Coupled Thermal Hydraulic Computer Model For Freezing Melt Flow in a Channel," September 1984.

NUREG/CR-3331, "A Methodology for Allocating Nuclear Power Plant Control Functions to Human or Automatic Control," August 1983.

NUREG/CR-3453, "Electronic Isolators Used in Safety Systems of U.S. Nuclear Power Plants," March 1986. 
NUREG/CR-4397, "In-plant Source Term Measurements at Prairie Island Nuclear Generating Station," J.W. Mandler et al., September 1985.

NUREG/CR-4461, "Tornado Climatology of the Contiguous United States, " May 1, 1986.

NUREG/CR-5132, "Severe Accident Insights Report," April 1988.

NUREG/CR-5210, "Technical Findings Document for Generic Issue 51: Improving the Reliability of OpenCycle Service-Water Systems," August 1988.

NUREG/CR-5341, "Round-Robin Analysis of the Behavior of a 1:6-Scale Reinforced Concrete Containment Model Pressurized to Failure: Posttest Evaluations, " Sandia National Laboratory, October 1989.

NUREG/CR-5405, "Analysis of Shell-Rupture Failure Due to Hypothetical Elevated-Temperature Pressurization of the Sequoyah Unit 1 Steel Containment Building," February 1990.

NUREG/CR-5414, Technical Findings for Proposed Integrated Resolution of Generic Issue 128, Electric Power Reliability," November 1989.

NUREG/CR-5423, "The Probability of Liner Failure in a Mark-I Containment," August 1991.

NUREG/CR-5564, "Core-Concrete Interactions Using Molten $\mathrm{UO}_{2}$ With Zirconium on a Basaltic Basemat," August 1992.

NUREG/CR-5572, "An Evaluation of the Effects of Local Control Station Design Configurations on Human Performance and Nuclear Power Plant Risk," September 1990.

NUREG/CR-5597, "In-Vessel Zircaloy Oxidation/ Hydrogen Generation Behavior During Severe Accidents, " September 1990.

NUREG/CR-5603, "Pressure-Dependent Fragilities for Piping Components," October 1990.

NUREG/CR-6049, "Piping Benchmark Problems for the GE ABWR," August 1993.

\section{Safety Evaluation Report}

"Review of NEDE-30996(P), 'SAFER Models for Evaluation of Loss-of-Coolant Accident for Jet Pump and Non-Jet Pump Plants,' Volumes I and II," February 19, 1987.

\section{Staff Requirements Memonanda}

June 26, 1990, "SECY-90-016, "Evolutionary Light Water Reactor (LWR) Certification Issues and Their Relationship to Current Regulatory Reguirements.'"

August 22, 1990, "Staff Requirements - Briefing on Essentially Complete Design Issue for Part 52

Submitials, (SECY-90-241)."

February 15, 1991, "SECY-90-377, 'Requirements for Design Certification Under 10 CFR Part 52."

April 1, 1991, August 15, 1991, "SECY-91-078, 'Chapter 11 of the Electric Power Research Institute's (EPRI's) Requirements Document and Additional Evolutionary Light Water Reactor (LWR) Certification Issues.'

September 24, 1991, "SECY-91-178, 'Inspections, Tests, Analyses, and Acceptance Criteria (ITAAC) for Design Certifications and Combined Licenses.' "

October 18, 1991, "SECY-91-210, 'Inspections, Tests, Analyses, and Acceptance Criteria (ITAAC) Requirements for Design Review and Issuance of a Final Design Approval (FDA).' "

October 25, 1991, "SECY-91-229, 'Severe Accident Mitigations Design Alternatives for Certified Standard Designs.'"

January 28, 1992, "SECY-91-262, 'Resolution of Selected Technical and Severe Accident Issues for Evolutionary Light Water Reactor (LWR) Designs.'"

April 30, 1993, "SECY-92-381, 'Rulemaking Procedures for Design Certification.'"

June 23, 1993, "SECY-92-287/287A, 'Form and Content For A Design Certification Rule.' 
June 24, 1993, "Staff Requirements - Briefing on Progress of Design Certification Review and Implementation (SECY-93-097), 10:00 A.M., Wednesday, June 2, 1993, Commissioners' Conference Room, One White Flint North, Rockville, Maryland (Open to Public Attendanco)."

July 21, 1993, "SECY-93-087, 'Policy, Technical, and Licensing Issues Pertaining to Evolutionary and Advanced Light-Water Reactor (ALWR) Designs.'"

\section{Other References}

Galletly, G.D., "A Simple Design Equation for Preventing Buckling in Fabricated Torispherical Shelis Under Internal Pressure, " ASME Joumal of Pressure Vessel Technology, Vol. 108, November 1986.

Kockler, F., et al., "Systems Engineering Management Guide," (AD/A223 168), Defense Systems Management College, Fort Belvoir, Virginia, 1990.

Matsuzawa, H., et al., "Dynamic Soil and Water Pressures on Submerged Soils," ASCE Journal of Geotechnical Engineering, Vol. 111, No. 10, October 1985.
Richards, R. Jr. and D.G. Elms, "Seismic Behavior of Gnvity Retaining Walls," ASCE Journal, GT Division, Vol. 105, April 1979.

Roark, R. J. and W. Young, Formulas for Stress and Strain, McGraw Hill, 1982.

Ruger, C.J., Brown, W.S., and Higgins, J.C., "Human Factors Deficiencies at Local Control Stations," Brookhaven National Laboratory, BNL A-3972-4-91, Upton, New York.

Shield, R.D. and D.C. Drucker, "Design of ThinWalled Torispherical and Toriconicval Pressure-Vessel Heads," Transections of ASME, June 1961.

Task Force on Wind Forces, "Wind Forces on Structures," Transactions of the American Society of Civil Engineere," Volume 126, Part II, Paper No. 3269, pp. 1124-1198, 1961.

Unrein, P.J., et al., "Transmission of lodine Through Sampling Lines," October 1984.

Williamson and Alvy, "Impact Effect of Fragments Striking Structural Elements," November 1973. 


\section{APPENDIX C}

\section{CHRONOLOGY OF CORRESPONDENCE}

This appendix contains a chronological listing of routine licensing correspondence between the U.S. Nuclear Regulatory Commission (NRC) staff and GE regarding the review of the Advanced Boiling Water Reactor (ABWR) under Project 671 and Docket Numbers 50-605 and 52-001.

\section{ABWR AMENDMENTS}

\begin{tabular}{||l|l|l|l||}
\hline AMENDMENTS & DATE & AMENDMENTS & DATE \\
\hline 1 & $03 / 29 / 88$ & 2 & $06 / 29 / 88$ \\
\hline 3 & $12 / 29 / 88$ & 4 & $01 / 31 / 89$ \\
\hline 5 & $02 / 28 / 89$ & 6 & $03 / 31 / 89$ \\
\hline 7 & $06 / 02 / 89$ & 8 & $07 / 28 / 89$ \\
\hline 9 & $11 / 17 / 89$ & 10 & $03 / 28 / 90$ \\
\hline 11 & $05 / 02 / 90$ & 12 & $06 / 04 / 90$ \\
\hline 13 & $07 / 03 / 90$ & 14 & $10 / 02 / 90$ \\
\hline 15 & $11 / 30 / 90$ & 16 & $02 / 22 / 91$ \\
\hline 17 & $06 / 28 / 91$ & 18 & $10 / 11 / 91$ \\
\hline 19 & $12 / 13 / 91$ & 20 & $03 / 13 / 92$ \\
\hline 21 & $07 / 06 / 92$ & 22 & $09 / 18 / 92$ \\
\hline 23 & $11 / 20 / 92$ & 24 & $01 / 07 / 92$ \\
\hline 25 & $01 / 29 / 92$ & 26 & $03 / 24 / 92$ \\
\hline 27 & $04 / 23 / 92$ & 28 & $05 / 14 / 93$ \\
\hline 29 & $05 / 28 / 93$ & 30 & $07 / 08 / 93$ \\
\hline 31 & $07 / 28 / 93$ & 32 & $09 / 17 / 93$ \\
\hline 33 & $12 / 07 / 93$ & $05 / 25 / 94$ & $03 / 31 / 94$ \\
\hline 35 & & & \\
\hline
\end{tabular}


August 7, 1987

August 11, 1987

August 31, 1987

December 14, 1987

December 24, 1987

February 22, 1988

February 29, 1988

March 15, 1988

March 24, 1988
T.E. Murley, NRC, letter forwarding, "GE Advanced BWR Reactor Licensing Review Bases." Report addresses review process, selected technical issues, and represents understanding of certain approaches proposed in design and licensing application.

Fiche: $\quad$ 42162:262-42162:287

ecn: $\quad 8708140039$

H.N. Berkow, meeting summary of August 5, 1987, with GE on plans for development and submittal of Technical Specifications for advanced BWR Standard plant design. GE to reconsider plans for technical specifications and continue to coordinate with owners group and NRC on item. List of attendees enclosed.

Fiche: $\quad$ 42171:073-42171:075

acn: $\quad 8708170023$

Text-safety report--"GE Advanced BWR Licensing Review Bases."

Fiche: $\quad$ 42162:264-42162:287

acn: $\quad \mathbf{8 7 0 8 1 4 0 0 4 3}$

R. Artigas, letter advising that GE send advanced BWR standard SAR per NRC request. Chapters for report will be submitted in blocks according to established scheduled.

Chapters 4, 5, 6, and 15 forwarded to ACRS at present.

Fiche: $\quad 43726: 286-43726: 286$

acn: $\quad 8712150419$

T.E. Murley, NRC, external memorandum directing staff to perform audit of GE advanced BWR design and design process in early 1988. Special emphasis will be placed on portions of design attributable to Toshiba and Hitachi for purpose of assuring quality and reliability of advanced BWR.

Fiche: $\quad$ 43953:350-43953:353

acn: $\quad \mathbf{8 8 0 1 0 7 0 1 7 0}$

D.C. Scaletti, NRC, letter forwarding requesting additional information regarding $G E$ application for certification of advanced BWR design by April 30, 1988. Request addresses areas of SRP Chapters 4, 5, 6, and 15 reviewed by Mechanical Materials and Chemical Engineering Branches.

Fiche: $\quad$ 44499:123-44499:137

acn: $\quad 8802250119$

D.C. Scaletti, NRC, letter submitting list of concerns to be addressed during February 23 through 25, 1988, preliminary design QA audit.

Fiche: $\quad 44558: 310-44558: 312$

acn: $\quad 8803030075$

L.S. Rubenstein, letter informing of relocation of NRR to stated address in Rockville, Maryland.

Fiche: $\quad 44746: 350-44746: 352$

acn: $\quad 8803210431$

B. Wolfe, letter requesting support in resolution of matter of fee to be incurred by GE in certification of advanced BWR. GE concerns would be resolved if Commission would confirm that review and foe both capped at present level and deferred.

Fiche: 45008:358-45008:360

acn: $\quad \mathbf{8 8 0 4 0 6 0 3 9 6}$ 
March 29, 1988

March 29, 1988

March 29, 1988

April 29, 1988

June 3, 1988

June 29, 1988

June 29, 1988

June 29, 1988

June 29, 1988

June 29, 1988
D.C. Scaletti, NRC, letter advises that information on advanced BWR fuel design in Chapter 4 of Supplemental SAR will bo withhold from public disclosures (Ref. 10 CFR 2.790) per September 29, 1988, request.

Fiche: $\quad 45029: 177-45029: 178$

acn: $\quad 8804050408$

Text-safety report-reference safety analysis report and amendments (RSAR) Amendment 1 Chapter 103 advanced BWR SSAR.

Ficho: $\quad$ 44953:262-44955:192

acn: $\quad \mathbf{8 8 0 3 3 1 0 0 2 9}$

R. Artigas, forwards Revision A to Amendment 1 to Chapters 1, 2, and 3 of 23A6100AC, "Advanced BWR SSAR." Replacement of overhead HPCS sparger with high pressure flooder spargers initiated with enclosures. Chapters 4, 5, 6, and 15 to be updated with 7 through 9 and 11 through 13 submitted.

Fiche: $\quad$ 44953:260-44955:192

acn: $\quad \mathbf{8 8 0 3 3 1 0 0 1 8}$

R. Artigas, letter forwarding responses to additional information on SSAR for advanced BWR per NRC February 22, 1988, request.

Fiche: 45505:093-45505:192

acn: $\quad 8805120071$

V. Stello, letter responding to March 24, 1988, letter regarding fee for design and approvals and certifications. Commission in process of examining fees for all types of reviews. GE concerns will be included in Commission review process.

Fiche: $\quad 45916: 347-45916: 347$

acn: $\quad \mathbf{8 8 0 6 2 4 0 2 3 5}$

Text-safety report--reference safety analysis report ard amendments (RSAR) Chapter 20, "Question and Response Guide," of Amendment 2 to GE Advanced BWR SSAR.

Fiche: $\quad$ 46024:194-46024:254

acn: $\quad \mathbf{8 8 0 7 0 5 0 0 1 4}$

Text-safety report--reference safety analysis report and amendments (RSAR) Chapter 17, "QA," of Amendment 2 to GE advanced BWR SSAR.

Fiche: $\quad$ 46024:183-46024:193

acn: $\quad \mathbf{8 8 0 7 0 5 0 0 1 3}$

Text-safety report--reference safety analysis report and amendments (RSAR) Chapter 14, "Initial Test Program," of Amendment 2 to GE advanced BWR SSAR.

Fiche: $\quad 46024: 109-46024: 182$

acn: $\quad \mathbf{8 8 0 7 0 5 0 0 1 1}$

Text-safety report-reference safety analysis report and amendments (RSAR) Chapter 13, "Conduct of Operations," of Amendment 2 to GE advanced BWR SSAR.

Fiche: $\quad 46024: 095-46024: 108$

acn: $\quad \mathbf{8 8 0 7 0 5 0 0 1 0}$

Test-safety report--reference safety analysis report and amendments (RSAR) Chapter 12, "Radiation Protection" of Amendment 2 to GE advanced BWR SSAR.

Fiche: $\quad$ 46024:014-46024:094

acn: $\quad 8807050009$ 
June 29, 1988

June 29, 1988

June 29, 1988

June 29, 1988

June 29, 1988

June 29, 1988

July 6, 1988

July 7,1988

July 28, 1988

September 12, 1988
Text-safety report--reference safety analysis report and amendments (RSAR) Chapter 11, "Radwaste Management" of Amendment 2 to GE advanced BWR SSAR.

Fiche: $\quad$ 46023:325-46024:013

scn: $\quad 8807050008$

Text-safety report--reference safety analysis report and amendments (RSAR) Chapter 9, "Auxiliary Systems" of Amendment 2 to GE advanced BWR SSAR.

Fiche: $\quad 46023: 187-46023: 324$

ecn: $\quad \mathbf{8 8 0 7 0 5 0 0 0 7}$

Text-safety report--reference safety analysis report and amendments (RSAR) Chapter 8, "Electric Power" of Amendment 2 to GE advanced BWR SSAR.

Fiche: 46023:126-46023:186

acn: $\quad 8807050006$

Text-safety report--reference safety analysis report and amendments (RSAR) Chapter 7, "Instrumentation and Control System," Amendment 2 to GE advanced BWR SSAR.

Fiche: $\quad$ 46022:092-46023:125

acn: $\quad 8807050005$

Text-safety report--reference safety analysis report and amendments (RSAR) Amendment 2 to GE advanced BWR SSAR.

Fiche: $\quad$ 46022:091-46024:254

acn: $\quad \mathbf{8 8 0 7 0 5 0 0 0 4}$

J.S. Gay, letter forwarding Amendment 2 to Chapters 7 through 9, 11 through 14, and 17 of SSAR for advanced BWR per NRC August 7, 1987, advanced BWR licensing review basis.

Fiche: $\quad$ 46021:047-46024:254

acn: $\quad 8807050003$

S. Gay, letter forwarding Figures 7.6-1 and 7.6-2 of Amendment 2 to GE advanced BWR SSAR. Figures withheld.

Fiche: $\quad 46175: 300-46175: 300$

acn: $\quad 8807140283$

D.C. Scaletti, NRC, letter forwarding request for additional information regard GE application for certification of advanced BWR design. Responses requested by September 15, 1988.

Fiche: $\quad 46154: 283-46154: 314$

acn: $\quad \mathbf{8 8 0 7 1 2 0 6 3 4}$

D.C. Scaletti, NRC, letter forwarding documents regarding NRC review of GE application for certification of advanced BWR design per February 1, 1988, meeting agreement. Without enclosures.

Fiche: $\quad 46467: 132-46467: 133$

acn: $\quad \mathbf{8 8 0 8 0 8 0 0 8 9}$

D.C. Scaletti, NRC, letter forwarding requesting additional information regarding GE application for certification of advanced BWR design for response by November 15, 1988.

Fiche: $\quad 46908: 325-46908: 337$

acn: $\quad 8809160120$ 
Seplember 14, 1988

September 20, 1988

September 26, 1988

September 28, 1988

September 29, 1988

October 26, 1988

November 14, 1988

November 22, 1988

December 9, 1988
P.W. Marriott, OE, letter forwarding with additional information regarding SSAR for advanced BWR per NRC July 7, 1988, request and committed reeponeses to D.C. Scaletti Fobruary 22, 1988, request. Manufacturer will amend SSAR with reeponece in December.

Fiche: 46911:136-46911:249

acn: $\quad 8809160103$

D.C. Scaletti, NRC, letter forwarding requesting additional information regarding application for certification of advanced BWR design for response by November 21, 1988, in order to maintain reviow schedule.

Fiche: 46945:261-46945:276

acn: $\quad 8809230178$

D.C. Scaletti, NRC, letter forwarding requesting additional information regarding application for cortification of advanced BWR design. Responses requestod by November 30, 1988.

Fiche: $\quad$ 47015:284-47015:309

acn: $\quad 8810030333$

D.C. Scaletti, NRC, meeting minutes-internal (non-transcript) of September 14, 1988, meeting with GE postulated all pump trip for advanced BWR design. List of attendees and viewgraphs enclosed.

Fiche: 47070:221-47070:235

acn: $\quad 8810060008$

R. Artigas, letter requesting design certification of advanced BWR standard plant per NRC review and approval of enclosed proprietary SSAR Chapters 4, 5, 6, and 16. Chapters withheld.

Fiche: 42917:105-42917:111

acn: $\quad 8710060280$

D.C. Scaletti, NRC, letter requesting additional information regarding GE application for certification of advanced BWR design. Information includes suppression pool water condensate storage tank discharge line fill pump and standby liquid control system.

Fiche: $\quad$ 47408:214-47408:224

acn: $\quad 8811010278$

P.W. Marriott, GE, letter responding to D.C. Scaletti September 12, 1988, request for additional information on SSAR for advanced BWR. Responses principally pertain to Chapters 1, 2, and 3. Responses to NRC July 7, 1988, letter also enclosed.

Fiche: $\quad 47567: 205-47567: 265$

acn: $\quad \mathbf{8 8 1 1 1 7 0 1 7 7}$

D. Crutchfield, NRC, letter providing recently developed information regarding scope of future standard design applications and of staff review of advanced BWR.

Fiche: $\quad$ 47696:239-47696:254

acn: $\quad 8811300135$

P.W. Marriott, GE, letter responding to September 20, 26, and October 26, 1988, requests for additional information regarding SSAR for advanced BWR. GE proprietary information withheld.

Fiche: $\quad$ 47795: 137-47795:302

acn: $\quad 8812130262$ 
December 27, 1988

Decomber 30, 1988

Docember 30, 1988

January 1, 1989

January 6, 1989

January 24, 1989

January 26, 1989

January 31, 1989

February 3, 1989
L.S. Rubenstein, letter requeating additional information listed in encloeure regarding deaign goals addreesing large radioactive releases resulting from severe accident.

Response requested with 30 days of lettor date.

Fiche: $\quad$ 44285:261-44285:263

acn: $\quad \mathbf{8 8 0 2 0 8 0 3 2 2}$

Toxt-anfoty report--reference safoty analysis report and Amendments (RSAR)

Amendment 3 to "Advanced BWR Stendard Plant," Chapter 10, "Stoem and Power Conversion System."

Ficho: 48093:051-48093:126

scn: $\quad 8901040053$

P.W. Marriott, GE, letter forwarding Amendment 30 to GE advanced BWR SSAR Chapter 10, "Steam and Power Conversion System," with responses to request for additional information which were submitted but not yet incorporated by amendment. Ficho: $\quad$ 48093:049-48093:126

acn: $\quad 8901040041$

P.W. Marriott, GE, letter forwarding responses to NRC requests for additional information submittod but not yot incorporated by amendment to SSAR for advanced BWR and Amendment 3 to advanced BWR SSAR.

Fiche: 48124:106-48125:324

acn: 8901100292

Text-safety report-safoty analysis report and amendments (RSAR) Amendment 3 to advanced BWR SSAR.

Fiche: 48125:019-48125:324

acn: 8901130338

Legal transcripts and orders and pleadings of January 24, 1989, briefing in Rockville, Maryland regarding progress of GE advanced BWR standard plant review. Page 1

through 63. Supporting information enclosed.

Fiche: $\quad$ 48453:228-48453:327

acn: $\quad 8902090339$

D.C. Scaletti, NRC, letter discussing NRC plans for visit to GE offices during week of February 6, 1989, to complete audit of QA program applied to advanced BWR design process.

Fiche: $\quad$ 48347:092-48347:094

acn: $\quad 8902020378$

P.W. Marriott, GE, letter forwarding proprietary Chapter 19, "response to severe accident policy statement," and Appendix 20a, "responses to additional information" of Amendment 4 to GE advanced BWR SSAR. Chapter 19 and Appendix 20a withheld. Fiche: $\quad$ 48414:015-48414:305

acn: $\quad 8902060235$

D.C. Scaletti, NRC, letter forwarding request for additional information regarding $G E$ application for certification of advanced BWR design. Request addresses areas of SRP Chapters 9 and 11 to 13 and question regarding thermal hydraulic stability. Response requested by March 6, 1989.

Fiche: $\quad 48428: 282-48428: 302$

acn: $\quad 8902080234$ 
Pobruary 28, 1989

Fobruary 28, 1989

March 7, 1989

March 31, 1989

March 31, 1989

May 16, 1989

June 2, 1989

June 2, 1989

June 16, 1989
Text-safoly report--reference safoty analysis report and amendments (RSAR)

nonproprietary Chepter 20 to Amondment 5 to "Advanced BWR SSAR."

Fiche: 48804:258-48805:233

ecn: $\quad 8903100068$

P.W. Marriott, OB, lotter forwarding Amendmeat 5 to "Advanced BWR SSAR" consiating of nonproprietary Chapter 20 and proprietary Sections 7.2 and 7.5. Bindors for Chapter 19 along with now tables for Chapters 1, 7 and 3 and affidavit aleo enclowed. Sections withheld.

Fiche: 48804:251-48805:233

ecn: $\quad 8903100064$

P.W. Marriott, GE, letter forwarding responses to NRC Fobruary 2, 1989, requeet for additional information reganding SSAR for advanced BWR. Response pertains to Chaptore 9, 11, 12 and 13.

Ficho: 48805:234-48805:325

sen: $\quad \mathbf{8 9 0 3 1 0 0 0 3 3}$

Text-safety report--reforence safety analysis report and amendments (RSAR).

Nonproprietary Ameadment 6 to GE advanced BWR SSAR.

Ficho: 49535:010-49536:339

acn: $\quad 8904250093$

P.W. Marriott, GE, lotter forwarding proprietary and nonproprietary portions of Amendment 6 to GE advanced BWR SSAR. Propriotary pages withhold.

Fiche: 49535:001-49536:339

acn: $\quad 8904250083$

D.C. Scaletti, NRC, letter to P.W. Marriott, GE, requesting additional information regarding application for cortification of advanced BWR design. Questions cover QA instrumentation and controls, olectromagnetic compatibility qualification and design and performance information. Response requested by July 11, 1989.

Fiche: 49955:214-49955:274

acn: $\quad 8905300058$

Test-safety report--nonproprietary Amendment 7 to GE advanced BWR SSAR.

Fiche: 50306:068-50308:010

ecn: $\quad 8906270069$

P.W. Marriott, GE, letter forwarding proprietary and nonproprietary sections of Amendment 7 to GE advanced BWR SSAR. Proprietary Soctions 9, 11, 15, 19b, and $19 \mathrm{c}$ withheld.

Ficho: 50306:063-50308:010

acn: $\quad \mathbf{8 9 0 6 2 7 0 0 6 2}$

D.C. Scaletti, NRC, forwarding letter to GE, advising of intended visit to audit process of verification and validation for advanced BWR software development.

Fiche: 50290:072-50290:077

acn: $\quad 8906260161$ 
June 16, 1989

June 19, 1989

June 23, 1989

June 23, 1989

June 28, 1989

June 30, 1989

June 30, 1989

July 13,1989

July 28,1989
C.L. Miller letter forwarding to P.W. Marriott, GE, with Director's Decision letter of transmittal and FR notice in responso to OCRE petition filed under 10 CFR 2.206. Petitioner expreseed concerns regarding March 9, 1989, power oscillation event at LeSalle Unit 2 and requested Commission action.

Fiche: 50291:038-50291:073

ecn: $\quad 8906260026$

C.L. Miller, NRC, letter forwarding to P.W. Marriott, GE, resolution of ontstanding advanced BWR Standard SAR issues reculting from OE/NRC May 31 and June 1, 1989, moetings. Proposed now Chapter 15 analysis for events impacted by impiementation of two motor-generator sots summarized.

Fiche: 50253:072-50253:132

acn: $\quad 8906220068$

P.W. Marriott, GE, letter forwarding proprietary resolution of outstanding advanced BWR SSAR issue regarding LOCA calculational method and responses to QA Branch request for additionally information dated May 16, 1989. Enclosure withheld.

Fiche: $\quad$ 50363:132-50363:132

acn: $\quad 8906290006$

P.W. Marriott, GE, letter forwarding with proposed tochnical specifications for advanced BWR SSAR Chapter 16 with exception of instrumentation Section 3.4. Changes listed.

Fiche: 50328:142-50329:275

acn: $\quad \mathbf{8 9 0 6 2 8 0 3 1 7}$

P.W. Marriott, GE, letter forwarding amended response to QA Branch on May 16, 1989, request for additional information regarding resolution of outstanding advanced BWR SSAR issues including compliance with quality-related regulatory guides and regulatory guides applicable to advanced BWR.

Fiche: 50418:017-50418:028

acn: $\quad 8907050305$

D.C. Scaletti, NRC, letter dated June 5, 1989, from Director's Office of NRR acknowledging receipt of petition filed by Ecology Center of Southern California and stating that petition is being treated under 10 CFR 2.206 .

Fiche: $\quad 50458: 114-50458: 120$

acn: $\quad 8907100212$

C.D. Gentillon, letter forwarding draft, "Component Failure Data Handbook," technical report.

Fiche: 70031:002-70031:167

acn: $\quad 8910250036$

acn: $\quad 9201290130$

J.S. Gay, letter forwarding additional information on SSAR for advanced BWR per D.C. Scaletti May 16, 1989, request. Responses principally pertain to Chapters 7 and 8.

Fiche: $\quad$ 50595:107-50595:154

acn: $\quad 8907190174$

Text-safety report--reference safety analysis report and amendments (RSAR).

Amendment 8 to GE advanced BWR SSAR.

Fiche: 50783:350-50785:039

acn: $\quad 8908030168$ 
July 28, 1989

August 2, 1989

August 4, 1989

August 7, 1989

August 17, 1989

August 23, 1989

August 25, 1989

August 31, 1989

September 29, 1989
P.W. Marriott, GE, letter forwarding proprietary and nonproprietary Amendment 8 to GE advanced BWR SSAR. Chapter 19 amended to include internal events. Submittal concludes primary SSAR submittals on certification program. Proprietary Amendment 8 withheld.

Fiche: $\quad 50783: 348-50783: 349$

acn: $\quad 8908030162$

P.W. Marriott, GE, letter forwarding to NRC May 16, 1989, request for additional information on SSAR for advanced BWR Chapters 7 and 8 regarding topical reports to support design and safety system logic and control power supply respectively.

Fiche: 50861:331-50861:352

acn: $\quad 8908090359$

R.C. Mitchell, letter forwarding corrected page 19.1-1 to Chapter 19, "Response to Severe Accident Policy Statement," of SSAR for advanced BWR correcting calculated core damage frequency from 4.27E-6 per year to 4.27E-7 per year. Proprietary page withheld.

Fiche: $\quad$ 50862:190-50862:191

acn: $\quad 8908090011$

T.E. Murley, NRC, letter provides clarification and further guidance regarding containment design to assure that containment conditional failure probability less than 1 in 10 when weighted over credible core damage sequences. Goal of 0.1 possible.

Fiche: 50916:133-50916:134

acn: $\quad 8908140099$

C.L. Miller, NRC, letter forwarding draft SER regarding final design approval and design certification of advanced BWR for use.

Fiche: 51045:279-51046:055

acn: $\quad 8908290025$

R.C. Mitchell, letter forwarding response to NRC May 16, 1989, for additional information on SSAR for advanced BWR regarding Chapters 7 and 8. Panel internal environmental maintained to ensure that reliability goals achieved.

Fiche: $\quad 51035: 326-51035: 343$

acn: $\quad 8908280230$

R.C. Mitchell, letter forwarding Amendment 8 to advanced BWR SSAR Chapter 13, "Conduct of Operations," Subsection 13.6, "Physical Security." Amendment withheld (Ref. 10 CFR 73.21).

Fiche: $\quad 51180: 238-51180: 238$

acn: $\quad 8909120028$

Text-safety report-licensing and related issues; draft SER regarding final design approval and design certification of advanced BWR.

Fiche: 51045:282-51046:055

acn: $\quad 8908290027$

Text-safety report--"Summary of In-Plant Test of Fine Motion CRD."

Fiche: 51545:317-51545:332

acn: $\quad 8910180231$ 


\section{Appendix C}

October 12, 1989

November 17, 1989

November 17, 1989

November 17, 1989

November 27, 1989

November 27, 1989

November 28, 1989

December 12, 1989

January 4, 1990

January 9, 1990
D.J. Robare, letter forwarding, "Summary of In-Plent Teat of Fine Motion CRD," in response to Quation 440.8 of July 7, 1989, request regarding find report on Fine Motion CRD In-Plant teat program.

Ficho: 51545:316-51545:332

scn: 8910180217

Text-enfety report-noaproprietary Amendment 8 to Advance BWR SSAR.

Ficho: $\quad$ 51853:095-51855:278

scn: $\quad 8911280344$

P.W. Marriott, GE, letter forwarding nonproprietary Amendment 9 to advanced BWR SSAR.

Ficho: 51853:093-51855:278

scn: $\quad 8911280341$

P.W. Marriott, GE, letter forwarding proprietary Amendment 9 to advanced BWR SSAR. Amendment withheld.

Fiche: 51830:080-51830:083

scn: 8911220239

P.W. Marriott, GE, letter forwarding proprietary section of Chapter 8 responses to May 16, 1989, request for additional information regarding SSAR for advanced BWR.

Fiche: $\quad 51918: 185-51918: 185$

acn: 8912050202

P.W. Marriott, GE, letter forwarding Chapter 8 responses to D.C. Scaletti May 16, 1989, request for additional information on SSAR for advanced BWR.

Fiche: $\quad$ 51896:200-51896:287

scn: $\quad 8912010101$

D.C. Scaletti, NRC, letter forwarding request for additional information reganding GE application for certification of advanced BWR design addressing severe accident review information provided in Appendix 19d of advanced BWR SSAR by January 8, 1990.

Fiche: $\quad$ 51890:004-51890:015

acn: $\quad 8912010069$

E.E. Nichols, letter forwarding advanced BWR master index and Amendment 8 changes per request. Without enclosures.

Fiche: $\quad 52758: 110-52758: 125$

scn: $\quad 9002270223$

E.E. Nichols, letter forwarding C.E. Buchholx December 27, 1989, letter to I. Madni floppy disk for files and printont of Readme filed from floppy. Without floppy disk.

Fiche: 52758:112-52758:125

acn: $\quad 9002270227$

P.W. Marriott, GE, letter forwarding proprietary Chapter 19 responses to November 28, 1989, request for additional information on SSAR for advanced BWR. Responses withheld.

Fiche: S2290:104-52290:104

ecn: $\quad 9001110137$ 
January 11,1990

January 11, 1990

January 17, 1990

January 18, 1990

January 26, 1990

January 31, 1990

February 9, 1990

February 28, 1990

February 28, 1990

March 13, 1990
E.E. Nichols, letter forwarding floppy disk containing data files from CAFTA fault tree program in response to Question 44 of November 28, 1989, letter. Enclosure withheld.

Fi=he: 52758:111-52758:111

scn: $\quad 9002270224$

R.C. Stim, letter forwarding response to items discussed during December 4 and 6, 1990, telcons on reactor systems regarding SER input for advanced BWR SSAR

Chapters 4, 5, 6, 9, and 15. Proprietary responses provided under separate cover.

P.W. Marriott, GE, letter forwarding page status listing dated December 11, 1989, for nonpropriotary pages of SSAR for advanced BWR. Listing identifies latest amendment number applicable for each page of SSAR.

Fiche: 52343:209-52343:251

scn: $\quad 9001190118$

C.P. Tan, trip report of November 28 through 30, 1989, visit to GE office in San Jose, California regarding audit of seismic design of advanced BWR and to resolve other outstanding issues as identified in advanced BWR draft SER in areas of branch review.

Fiche: 70141:149-70141:173

acn: $\quad 9002070111$

D.C. Scaletti, NRC, letter requesting additional information regarding GE application for certification of advanced BWR design. Response requested by February 28, 1990. Fiche: $\quad$ 52542:014-52542:018

acn: $\quad 9002050031$

J.N. Singh, text-procurement and contracts, "Advanced BWR Standard Plant Seismic Design Review," informal report.

Fiche: 70141:154-70141:173

ecn: $\quad 9002070112$

D.C. Scaletti, NRC, letter notifies of preliminary audit scheduled for February 14 and 15, 1990, regarding advanced BWR design. Audit team members listed.

Fiche: $\quad$ 52776:107-52776:107

acn: $\quad 9002280162$

D.C. Scaletti, NRC, letter notifies of March 6 and 7, 1990, meetings to discuss advanced BWR control room design regarding Chapter 18 review and human factors assumptions used in advanced BWR PRA. Agenda enclosed.

Fiche: 52894:043-52894:047

acn: $\quad 9003080256$

R.C. Mitchell, letter forwarding response to January 26, 1990, request for additional information on SSAR for advanced BWR. Licensee will amend SSAR with response in future amendment.

Fiche: $\quad 52798: 119-5279 d: 144$

acn: $\quad 9003020238$

A.H. Hsia, meeting summaries-internal (non-transcript) summary of November 28 through 30,1989, meetings with GE in San Jose, California regarding seismic and soilstructure issues in draft SER and seismic design audit on GE advanced BWR. List of attendees handouts presented at meeting and trip report enclosed.

Fiche: 53958:149-53958:180

Fiche: 70208:238-70208:295

acn: $\quad 9003210165$ 
Appendix C

March 14, 1990

March 28, 1990

March 28, 1990

March 28, 1990

April 5, 1990

April 16, 1990

May 1, 1990

May 1, 1990

May 1, 1990
D.C. Scaletti, NRC, letter forwarding request for additional information regarding application for certification of advanced BWR design.

Fiche: 53079:018-53079:023

acn: $\quad 9003200064$

P.W. Marriott, GE, letter forwarding proprietary sections of Chapters 6, 8, 9, 12, 19 , and 20 of Amendment 10 to SSAR for advanced BWR. Sections withheld.

Fiche: $\quad$ 53265:068-53265:069

acn: $\quad 9004020088$

Text-safety report--Amendment 10 to advanced BWR SSAR.

Fiche: 53254:020-53256:035

acn: $\quad 9004030278$

P.W. Marriott, GE, letter forwarding non-proprietary information consisting of Amendment 10 to GE advanced BWR SSAR. Submittal also includes response to TMI Action Item II.B.2 regarding plant shielding and descriptions of combustion turbinegenerator and lower drywell flooder.

Fiche: 53254:018-53256:035

acn: $\quad 9004030276$

S.S. Dua, letter forwarding draft amendment to SSAR updating Section 4.6, "Functional Design of Reactivity Control System," to incorporate electro-mechanical brake replacing original centrifugal brake. Proprietary enclosure withheld.

Fiche: 53372:010-53372:022

acn: $\quad 9004090346$

P.W. Marriott, GE, letter forwarding response to March 14, 1990, request for additional information regarding SSAR for advanced BWR Chapters 7 and 10 covering hardwaresoftware constraints, performance constraints, system and equipment levels, and oxygen system injection.

Fiche: 53524:030-53524:057

date: $\quad 900416$

D.C. Scaletti, NRC, letter forwarding preliminary draft safety evaluation regarding GE application for certification of advanced BWR design. Requests schedule that is consistent with resolving identified outstanding issues by end of May 1990.

Fiche: $\quad$ 53732:180-53732:233

acn: $\quad 9005070389$

D.C. Scaletti, NRC, letter forwarding preliminary draft safety evaluation regarding staff review of utility application for certification of advanced BWR design. Requests schedule consistent with resolving outstanding issues by end of May 1990.

Fiche: 53789:140-53789:193

acn: $\quad 9005100142$

D.C. Scaletti, NRC, letter forwarding request for additional information regarding GE application for certification of advanced BWR designs. Response requested by May 30, 1990.

Fiche: 53745:034-53745:043

acn: $\quad 9005070353$ 
May 2, 1990

May 2, 1990

May 2, 1990

May 2, 1990

May 4, 1990

May 10, 1990

May 14, 1990

May 16, 1990

May 16, 1990

Text-safety report--nonproprietary sections of Amendment 11 to GE advanced BWR SSAR covering response to standby gas treatment system questions addition of initial test program for turbine island and radwaste facilities and draft SER open items.

Fiche: 53900:094-53900:229

acn: $\quad 9005220232$

G.L. Sozni, corrected letter forwarding listed nonproprietary sections of Amendment 11 to GE advanced BWR SSAR including Chapter 1, "Introduction and General

Description of Plant," and Chapter 3, "Design of Structures Components Equipment and System...".

Fiche: $\quad 53900: 092-53900: 229$

acn: $\quad 9005220228$

Text-safety report--nonproprietary Amendment 11 to GE advanced BWR SSAR with May 23, 1990, letter.

Fiche: $\quad 53749: 207-53751: 018$

acn: $\quad 9005080015$

G.L. Sozzi, letter forwarding proprietary and nonproprietary sections of Amendment 11 to GE advanced BWR SSAR. Proprietary version withheld.

Fiche: $\quad$ 53749:205-53751:018

acn: $\quad 9005080013$

D.C. Scaletti, NRC, letter forwarding request for additional information regarding application for certification of advanced BWR design. Response requested by May 30, 1990.

Fiche: $\quad 53742: 347-53742: 356$

acn: $\quad 9005070352$

D.C. Scaletti, NRC, letter forwarding NRC summary of November 28 through 30 , 1989, meeting in San Jose, California regarding outstanding seismic and soil-structure issues. Schedule requested consistent with resolving outstanding issues by May 31, 1990.

Fiche: 53958:146-53958:205

acn: $\quad 9005300013$

D.C. Scaletti, NRC, notification of May 16 and 17, 1989, meeting with GE in San Jose, California to discuss NRC review of advanced BWR including drywell head failure containment overpressure protection source term and shutdown risk. Agenda enclosed.

Fiche: $\quad 53865: 148-53865: 152$

acn: $\quad 9005170166$

R.C. Mitchell, provides additional information regarding automatic despressurizer system (ADS) timer concerning engineering operating procedures. Advs actuation should be allowed to occur and quickly depressurize vessel if high pressure ECCS cannot control water level.

Fiche: $\quad 53920: 359-53920: 359$

acn: $\quad 9005240043$

R.C. Mitchell, NRC, letter forwarding response to outstandiny issues and request for additional information from November 28 through 30, 1989, advanced BWR seismic design audit at GE offices in San Jose, California. Information resolves Sections 2 and 3 to draft SER and action items.

Fiche: $\quad 53902: 106-53902: 195$

acn: $\quad 9005220234$ 
Appendix C

May 31, 1990

May 31, 1990

P.W. Marriott, GE, letter forwarding Chapter 12 responses to May 4, 1990, request for additional information on SSAR for advanced BWR. Chapter 11 responses are GE proprietary and will be submitted under separate cover.

Fiche: $\quad 54086: 086-54086: 087$

acn: $\quad 9006060323$

P.W. Marriott, GE, letter forwarding proprietary responses to resolve safety evaluation issues for advanced BWR SSAR Chapters 3, 6, and 11 per D.C. Scaletti May 1, 1990, request. Responses withheld.

Fiche: 54000:004-54000:004

acn: $\quad 9006040321$

May 31, 1990

P.W. Marriott, GE, letter forwarding proprietary responses to D.C. Scaletti May 1, 1989, request for additional information regarding SSAR Chapter 19. SSAR will be amended with responses in future amendment. Responses withhold.

Fiche: 54000:003-54000:003

acn: $\quad 9006040314$

May 31, 1990

P.W. Marriott, GE, letter forwarding proprietary response to D.C. Scaletti May 1, 1989, request for additional information regarding Amendments 4 and 8 to GE advanced BWR SSAR. With proprietary fragility calculations and 25 oversize proprietary drawings. Proprietary calculations and drawings withheld.

Fiche: $\quad$ 54112:166-54112:167

acn: $\quad 9006070191$

June 4, 1990

Text-safety report--nonproprietary Chapters 1, 3, 4, 6, 9, 10, 15, and 20 of Amendment 12 to GE advanced BWR SSAR.

Fiche: $\quad$ 54065:280-54066:042

acn: $\quad 9006060294$

June 4, 1990

P.W. Marriott, GE, letter forwarding nonproprietary Chapters 1, 3, 4, 6, 9, 10, 15, and 20 of Amendment 12 to GE advanced BWR SSAR.

Fiche: 54065:278-54066:042

acn: $\quad 9006060283$

June 4, 1990

P.W. Marriott, GE, letter forwarding proprietary Figure 4.6-6 of Amendment 12 to GE advanced BWR SSAR. Figure withheld.

Fiche: $\quad$ 54088:358-54088:358

acn: $\quad 9006070057$

June 7, 1990

S.S. Dua, letter forwarding Chapter 11 responses to D.C. Scaletti May 31, 1990, request for additional information on SSAR for advanced BWR. Responses withheld. Fiche: $\quad$ 54201:195-54201:195 acn: $\quad 9006120098$

June 7, 1990

S.S. Dua, letter forwarding proprietary drawings providing additional information regarding GE advanced BWR SSAR per D.C. Scaletti May 4, 1990, request. Material regarding Chapter 11 proprietary information sent to NRC per Amendment 6 to SSAR. With 38 proprietary drawings. Drawings withheld.

Fiche: $\quad$ 54192:064-54192:065

acn: $\quad 9006140139$ 
June 8, 1990

June 12, 1990

June 15, 1990

June 29, 1990

July 3, 1990

July 3, 1990

July 12,1990

July 12, 1990

July 12,1990

July 13, 1990

D.C. Scalett, NRC, moeting summaries-internal (non-transcript) summary of May 15 and 17, 1990, meeting with GE in Sen Jose, California regarding advanced BWR.

Fiche: $\quad$ 54194:066-54194:078

acn: $\quad 9006140231$

D.R. Wilkins, NRC, letter forwarding comparison of advanced LWR requirements document and OE advanced BWR SSAR design.

Fiche: 55005:127-55005:136

acn: $\quad 9008220012$

J. Taylor, NRC, compares GE advanced LWR SSAR design with current advanced LWR requirements document. GE advanced LWR SSAR design provides unique opportunity to demonstrate new 10 CFR Part 52 standard plant licensing process.

Fiche: 54370:144-54370:145

acn: $\quad 9007020036$

P.W. Marriott, GE, letter forwarding proprietary Chapter 11 responses to D.C. Scaletti May 4, 1990, request for additional information on SSAR for advanced BWR.

Responses withheld.

Ficho: $\quad$ 54426:337-54426:337

acn: $\quad 9007060022$

P.W. Marriott, GE, Text-safety report Amendment 13 to GE advanced BWR SSAR.

With July 3, 1990, letter.

Fiche: 54435:036-54436:038

acn: $\quad 9007090031$

P.W. Marriott, GE, letter forwarding proprietary soctions of Amendment 13 to GE advanced BWR SSAR consisting of Chapters 11 and 18 through 20. Enclosure withbeld.

Fiche: $\quad 54433: 310-54433: 311$

ecn: $\quad 9007090316$

G.W. Ehlert, general external technical reports, "Advanced BWR Control Building Seismic Report."

Fiche: $\quad$ 54646:067-54646:104

acn: $\quad 9007200234$

P.W. Marriott, GE, letter forwarding, "Advanced BWR Control Building Seismic

Report," per request. GE will amend SSAR with response in future amendment.

Fiche: 54646:065-54646:104

acn: $\quad 9007200228$

P.W. Marriott, GE, letter forwarding proposed modifications to zinc injection system deacribed in Subsection 9.3.11 of SSAR for advanced BWR. Modification will provide necessary plant features so that zinc injection to feedwater may be added if advisable.

Fiche: $\quad 54626: 307-54626: 312$

acn: $\quad 9007190246$

P.W. Marriott, GE, letter forwarding responses to resolve safety evaluation issues per D.C. Scaletti May 1, 1990, request. Issues cover method of attachment of level instruments that facilitate automatic switch over of pumps from condensate storage tank to suppression pool.

Fiche: $\quad 54604: 006-54604: 011$

ecn: $\quad 9007180280$ 


\section{Appendix C}

July 16, 1990

July 23, 1990

July 27,1990

August 8, 1990

August 9, 1990

August 15, 1990

August 22, 1990

August 22, 1990

August 22, 1990
P.'W. Marriott, GE, letter forwarding draft of modified advanced BWR SSAR Figure 9.2-5 Sheet 1 and new advanced BWR SSAR Figure 9.2-5 Sheet 3 regarding description of remaining makeup water system within scope of SSAR. With two oversize figures.

Fiche: $\quad 54607: 188-54607: 189$

acn: $\quad 9007180271$

P.W. Marriott, GE, letter forwarding fuel pool cooling and cleanup system clarifications and draft revisions to SSAR for advanced BWR.

Fiche: 54704:331-54704:339

acn: $\quad 9007260054$

D.C. Scaletti, NRC, letter forwarding request for additional information regarding GE application for certification of advanced BWR design.

Fiche: $\quad 54805: 335-54805: 348$

acn: $\quad 9008020005$

P.W. Marriott, GE, letter provides schedule for providing responses to Chapter 18 request for additional information. GE will provide 20 percent of responses regarding request for additional information by September 28, 1990.

Fiche: $\quad$ 54953:359-54953:359

date: $\quad 900808$

P.W. Marriott, GE, letter forwarding responses to discussion items from May 16 and 17,1990 , meetings including drywell head failure containme' it overpressures protection source term and fire and seismic risk.

Fiche: 54956:311-54956:322

acn: $\quad 9008130232$

D.C. Scaletti, NRC, letter forwarding request for additional information regarding GE application for certification of advanced BWR design. Responses to Encl sure 1 requested by August 31, 1990, and responses to Enclosures 2 and 3 by Si ptember 28, 1990.

Fiche: $\quad 55015: 314-55015: 339$

acn: $\quad 9008230027$

P.W. Marriott, GE, letter forwarding Chapter 10, "Steam and Power Conversion System," draft revisions to SSAR for advanced BWR. Information provided to clarify portions of SSAR Subsections 10.4.4 and 10.4.5 regarding turbine bypass system and circulating water system respectively.

Fiche: $\quad$ 55060:350-55060:353

acn: $\quad 9008290069$

P.W. Marriott, GE, letter forwarding response to August 15, 1990, request for additional information regarding SSAR for advanced BWR. Licensee will amend SSAR with responses in future amendments.

Fiche: $\quad$ 55060:009-55060:030

acn: $\quad 9008280004$

P.W, Marriott, GE, letter forwarding proprietary Chapter 9 responses to D.C. Scaletti letter dated August 15, 1990, requesting additional information on SSAR for advanced BWR.

Fiche: $\quad 55054: 230-55054: 230$

acn: $\quad 9008240119$ 
August 23, 1990

September 14, 1990

September 19, 1990

September 28, 1990

September 28, 1990

September 28, 1990

October 2, 1990

October 2, 1990

October 2, 1990

October 9, 1990

October 9, 1990
P.W. Marriott, GE, letter forwarding proprietary Chapter 18, "Human Factors, " draft revisions to standard SAR for advanced BWR. Enclosure withheld.

Fiche: 55076:150-55076:150

acn: $\quad 9008310014$

P.W. Marriott, GE, letter forwarding balance of proprietary Chapter 11 responses to D.C. Scaletti May 4, 1990, request for additional standards SAR for advanced BWR. Enclosure withheld.

D.C. Scaletti, NRC, letter forwarding request for additional for certification of advanced BWR design.

Fiche: $\quad 55294: 338-55294: 353$

acn: $\quad 9009260234$

R.C. Stim, letter forwarding Chapter 9 responses to request for additional information on SSAR for advanced BWR per D.C. Scaletti letter dated August 15, 1990.

Fiche: $\quad$ 55498:159-55498:255

acn: $\quad 9010160153$

R.C. Stim, letter forwarding drafts of modified advanced BWR SSR proprietary Figures 9.3-6 and 9.3-7 per D.C. Scaletti letter dated August 15, 1990. With three oversize figures. Figures withheld.

Fiche: $\quad$ 55513:100-55513:101

acn: $\quad 9010170040$

R.C. Stim, letter forwarding Chapter 9 proprietary responses to request for additional information on SSAR for advanced BWR per D.C. Scaletti letter dated August 15, 1990. Responses will be used in future amendments of SSAR. Enclosure withheld.

Fiche: 55498:054-55498:054

D.J. Robare, letter forwarding proprietary Amendment 14 to GE advanced BWR SSAR. Amendment 14 withheld.

Fiche: $\quad 55490: 118-55490: 119$

acn: $\quad 9010160159$

Text-safety report--Amendment 14 to advanced BWR SSAR.

Fiche: 55413:052-55414:106

acn: $\quad 9010090076$

D.J. Robare, letter forwarding nonproprietary Amendment 14 to advanced BWR SSAR.

Fiche: 55413:050-55414:106

acn: $\quad 9010090072$

P.W. Marriott, GE, letter forwarding response to NRC July 27,1990 , request for additional information on SSAR for advanced BWR. Response to Questions 620.3, $620.7,620.13,620.16,620.19,620.25$, and 620.29 . Contain proprietary information and will be submitted under separate cover.

Fiche: 55552:090-55552:092

acn: $\quad 9010240040$

P.W. Marriott, GE, letter forwarding proprietary responses to additional information requested in NRC letter dated July 27, 1990.

Fiche: 55528:187-55528:187

acn: $\quad 9010220184$ 
October 17, 1990

October 26, 1990

October 26, 1990

October 28, 1990

November 2, 1990

November 5, 1990

November 13, 1990

November 15, 1990

November 30, 1990
P.W. Marriott, GE, letter forwarding proprietary response to NRC/GE May 16 and 17, 1990, moeting Discussion Topics 4 and 5 regarding shutdown risk and lower drywoll flooder. Enclosures withhold.

Fiche: $\quad$ 55558:188-55558:189

ecn: $\quad 9010230066$

P.W. Marriott, GE, letter forwarding responses to D.C. Scaletti August 15, 1990, request for additional information regarding SSAR Chapter 9.

Fiche: $\quad$ 55739:317-55739:330

ecn: $\quad 9011060144$

P.W. Marriott, GE, letter forwarding revised Chapter 11 responses to Questions 430.157 and 430.165B per May 4, 1990, request for additional information rogarding SSAR. Clarifications regarding onsite radwaste storage and SSAR modifications also encloeed. Propriotary enclosures withheld.

Fiche: 55685:121-55685:121

acn: $\quad 9011010211$

P.W. Marriott, GE, letter forwarding Chapter 9 proprietary information response to Question 430.215 per August 15, 1990, request for additional information regarding SSAR.

Fiche: $\quad 55674: 170-55674: 170$

acn: $\quad 9011010224$

P.W. Marriott, GE, letter forwarding response to NRC July 27, 1990, request for additional information on SSAR for advance BWR. Response to Question 620.28 contains information which is proprietary and will be submitted under separate cover. Fiche: 55776:071-55776:086

acn: $\quad 9011130179$

Fiche: 55757:062-55757:062

ecn: $\quad 9011090101$

R.C. Mitchell, NRC, letter forwarding Chapter 11, "Radwaste Management," draft revisions per March 31, 1989, submittal or Amendment 6 to advanced BWR SSAR. Enclosure withheld.

Fiche: 55844:023-55844:023

acn: $\quad 9011130053$

P.W. Marriott, GE, letter forwarding proprietary information of preliminary update of fuel related portions of SSAR for advanced BWR. Enclosures withheld.

Fiche: $\quad 55877: 251-55877: 251$

acn: $\quad 9011160204$

P.W. Marriott, GE, letter forwarding proprietary additional information regarding Chapter 9 responses on fire protection diesel generator and station blackout concerning standard SAR for advanced BWR. Enclosures withheld.

Fiche: $\quad$ 55949:032-55949:032

acn: $\quad 9011260065$

Text-safety report-Amendment 15 to advanced BWR SSAR

Fiche: 56008:003-56009:271

acn: $\quad 9012060054$ 
November 30, 1990

November 30, 1990

November 30, 1990

December 17, 1990

December 17, 1990

December 20, 1990

December 20, 1990

December 21, 1990

December 21, 1990

January 1, 1991
P.W. Marriott, GE, letter forwarding Amendment 15 to advanced BWR SSAR.

Fiche: 56008:001-56009:271

acn: $\quad 9012060038$

P.W. Marriott, GE, letter forwarding proprietary Amendment 15 to advanced BWR SSAR. Amended sections include: Chapter 2, "Site Characteristics;" Chapter 3, "Design of Structures Components Equipment and Syetem;" Chapter 4, "Reactor;" and Chapter 6, "BSF."

Fiche: $\quad 56028: 279-56028: 281$

acn: $\quad 9012060029$

P.W. Marriott, GE, letter forwarding revised portions of Subsections 13.6, "Physical Security," of Amendment 15 to Advanced SSAR Chapter 13, "Conduct of Operations," and 20.3, "Queations and Reeponse Guide." Enclosures withheld.

Fiche: $\quad$ 59563:052-59563:052

scn: $\quad 9110300217$

P.W. Marriott, GE, letter forwarding final submittal of Chapter 18 proprietary information in response to July 27,1990 , request for additional information on standard SAR for advanced BWR. Enclosures withheld.

Fiche: $\quad 56182: 282-56182: 282$

acn: $\quad 9012210011$

P.W. Marriott, GE, letter submitting final response to July 27, 1990, request for additional information on standard SAR for advanced BWR Chapter 18. Proprietary responses being submitted separately.

Fiche: $\quad 56154: 146-56154: 156$

acn: $\quad 9012200121$

D.C. Scaletti, NRC, letter forwarding request for additional information regarding application for certification of advanced BWR design.

Fiche: $\quad 56251: 146-56251: 168$

acn: $\quad 9101020308$

R.C. Stirn, letter forwarding proprietary responses to Chapter 9 of SSAR regarding fire protection emergency diesel generators and station blackout per D.C. Scaletti September 19, 1990, request. Enclosures withheld.

Fiche: $\quad 56225: 299-56225: 300$

ecn: $\quad 9012270291$

Text-safety report-Amendment 15 to GE advanced BWR SSAR consisting of Chapter 5, "Figures."

Fiche: $\quad 56433: 002-56433: 089$

acn: $\quad 9101080339$

R.C. Stim, letter forwarding Amendment 15 to GE advanced BWR SSAR consisting of Chapter 5, "Figures."

Fiche: $\quad$ 56433:001-56433:089

acn: $\quad 9101080237$

W.B. Torres, text-specifications and test reports Revision A to "IOP-4 Power Ascension and Power Changes."

Fiche: $\quad 56389: 104-56389: 114$

acn: $\quad 9101110234$ 
January 8, 1991

Jenuary 8, 1991

January 8, 1991

January 9, 1991

January 9, 1991

January 9, 1991

Jenuary 9, 1991

January 9, 1991

January 9, 1991

January 9, 1991

January 9, 1991
Toxt-eafoty report-nonproprietary replecement figures for GE advanced BWR SSAR.

Fiche: $\quad 56431: 341-56431: 362$

ecn: $\quad 9101140028$

D.J. Robare, letter forwarding nonproprietary replacement figures for GE advanced BWR SSAR. Page size changed from $81 / 2 \times 11$ to $11 \times 17$.

Ficho: $\quad 56431: 340-56431: 362$

sen: $\quad 9101140026$

D.J. Robare, lotter forwarding proprietary replacement figures for GE advanced BWR SSAR. Page size changes from $81 / 2 \times 11$ to $11 \times 17$. Bnclosures withheld.

Fiche: 56369:039-56369:041

ecn: $\quad 9101100034$

W.B. Torres, text-specifications and test reports Revision to "IOP-10 Unit On-Line from Hot Standby or Hot Shutdown."

Fiche: $\quad 56389: 155-56389: 162$

acn: $\quad 9101110246$

W.B. Torres, text-specifications and test reports Revision to "IOP-9 Maintaining Hot Standby or Hot Shutdown."

Fiche: $\quad 56389: 148-56389: 154$

ecn: $\quad 9101110245$

W.B. Torres, text-specifications and test reports Revision A to "IOP-8 Unit Off-line to Hot Standby or Hot Shutdown."

Fiche: 56389:141-56389:147

acn: $\quad 9101110244$

W.B. Torres, text-specifications and test reports Revision A to "IOP-7 Cooldown to Cold Shutdown Main Condenser Not Available."

Fiche: $\quad 56389: 131-56389: 140$

acn: $\quad 9101110240$

W.B. Torres, text-specifications and test reports Revision A to "IOP-6 Cooldown to Cold Shutdown Main Condenser Available."

Fiche: $\quad$ 56389:121-56389:130

acn: $\quad 9101110239$

W.B. Torres, text-specifications and test reports Revision A to "IOP-5 Unit Shutdown to Unit Off-line Main Condenser Available."

Fičhe: $\quad 56389: 115-56389: 120$

acn: $\quad 9101110236$

W.B. Torres, text-specifications and test reports Revision A to "IOP-3 Turbine Startup and Generator Synchronization."

Fiche: $\quad 56389: 093-56389: 103$

acn: $\quad 9101110233$

W.B. Torres, text-specifications and test reports Revision A to "IOP-2 Heatup and Prescurization."

Fiche: $\quad 56389: 082-56389: 092$

acn: $\quad 9101110230$ 
Jenuary 9, 1991

January 9, 1991

January 9, 1991

January 9, 1991

January 11, 1991

January 17,1991

February 5, 1991

February 20, 1991

February 20, 1991
W.B. Torres, lext-especifications and leet reports Revision A to "IOP-1 Approsch to Criticality."

Fiche: $\quad 56389: 075-56389: 081$

ecn: $\quad 9101110229$

W.B. Torres, text-epecifications and teat reports Revision A to "RCIC Syatem Operating Procedures SOP-E51."

Ficho: 56389:054-56389:074

acn: $\quad 9101110225$

W.B. Torres, text-specifications and teat reports Revision A to "RHR System Operating Procedures SOP-E11."

Fiche: 56389:023-56389:053

ecn: $\quad 9101110223$

D.J. Robare, letter forwarding revised response to Queation 620.8 to clarify position regarding standardized training materials per NRC July 27, 1990, and September 2 letters. Sumples of ABWR Operating Procedure and Integrated Operating Procedures also enclosed.

Fiche: $\quad 56389: 021-56389: 162$

acn: $\quad 9101110211$

R.C. Stirn, letter forwarding proprietary information responses to discussion items regarding telcons concerning SER input for advanced BWR SSAR Chapters 4, 5, 6, 9, and 15 on reactor systems. Responses withheld.

Ficho: 56516:273-56516:274

ecn: $\quad 9101280128$

D.J. Rokere, letter forwarding proprietary response to Question 430.162 and Revised Response to Question 430.166F regarding Chapter 11 of SSAR for advanced BWR per May 4, 1990, request for additional information. Response withheld.

Fiche: $\quad$ 56506:134-56506:134

acn: $\quad 9101240071$

S.S. Dua, letter forwarding response to discussion Item 1 of January 1, 1991, GE/NRC telcon regarding seismic review portion of advanced BWR SSAR including impact of changes in seismic hazard function on seismic screening procedure.

Fiche: $\quad 56660: 184-56660: 186$

acn: $\quad 9102110001$

P.W. Marriott, GE, letter forwarding proprietary response to December 20, 1990, NRC request for additional information regarding SSAR for advanced BWR. Enclosures withheld.

Fiche: $\quad 56924: 134-56924: 134$

acn: $\quad 9103070196$

P.W. Marriott, GE, letter responding to NRC December 20, 1990, request for additional information regarding SSAR for advanced BWR.

Fiche: $\quad$ 56922:215-56922:298

acn: $\quad 9103070037$ 
February 21, 1991

February 22, 1991

February 22, 1991

February 22, 1991

Fobruary 22, 1991

February 22, 1991

March 25, 1991

March 28, 1991

March 28, 1991

March 28, 1991
D. Crutchfield, NRC, letter diccuses sovere accident mitigation deaign alternatives for cortified atandard deaigns. Licensees to inform NRC regarding plans to consider sovero sccident mitigation deaign altornative for propoeed deaigns.

Fiche: $\quad$ S6857:178-56857:181

ecn: $\quad 9102280120$

P.W. Marriott, GB, letter forwarding proprietary response to February 1, 1991, conference call regarding safeguards per Fobruary 6, 1989, submittal of Amendment 7 to advanced BWR SSAR.

Ficho: $\quad$ 56847:356-56847:356

scn: 9102280094

Text-eafoty report-analysis report and amondments (RSAR) Amendment 16 to advanced BWR SSAR

Ficho: $\quad$ 56854:081-56855:202

acn: $\quad 9102280049$

P.W. Marriott, GE, letter forwarding Amendment 16 to advanced BWR SSAR.

Ficho: $\quad$ 56854:077-56855:202

acn: $\quad 9102280031$

P.W. Marriott, GE, letter forwarding proprietary Amendment 16 to advanced BWR SSAR consisting of sections of Chapters 1, 4, 6, 9, 11, 15, and 20. Enclosures withheld.

Fiche: $\quad 56850: 207-56850: 211$

acn: $\quad 9102280021$

P.W. Marriott, GE, letter forwarding responses to safeguards discussion items from February 1, 1991, telcon. Responses withbeld (Ref. 10 CFR 73.21).

Fiche: $\quad$ 57219:170-57219:170

acn: $\quad 9104010347$

C.L. Miller, NRC, letter requesting that GE review STS and make appropriate revisions to documents to reflect proposed technical specifications regarding advanced BWR.

Fiche: $\quad$ 57280:131-57280:133

acn: $\quad 9104050129$

C. Poslusny, NRC, summary of March 4 through 6, 1991, meetings with GE in San Jose, California regarding selected open items from review of SSAR for advanced BWR. List of meeting attendees enclosed.

Fiche: $\quad$ 57250:204-57250:208

acn: $\quad 9104040176$

P.W. Marriott, GE, letter forwarding response to open items from March 4 through 6, 1991, meetings on plant systems.

Fiche: $\quad$ 57242:042-57242:150

acn: $\quad 9104020307$

P.W. Marriott, GE, letter forwarding proprietary information responses to open items regarding App $3 i$ and Section 11.4 of advanced BWR SSAR per summary status of GENRC March 4 through 6, 1991, meeting on plant system open items dated March 28, 1991, and March 31, 1991, submittal of Amendment 6. Enclosures withheld.

Fiche: $\quad$ 57242:321-57242:321

acn: $\quad 9104020277$ 
April 1, 1991

April 1, 1991

April 10, 1991

April 12, 1991

April 16, 1991

April 26, 1991

May 3, 1991

May 10, 1991

May 10, 1991
P.W. Marriott, GE, lettor forwarding reeponese to discuseion items of Fobruary 19, 1991, OE-NRC Reactor Syetem Branch conference call. GE will amend SSAR where appropriate with reeponso in future.

Ficho: $\quad$ 57319:014-57319:116

scn: $\quad 9104090196$

P.W. Marriott, GE, letter forwarding response to discuseion itom of March 29, 1991, GE-NRC Performance and Quality Evaluation Branch conforence call. GE: will amend SSAR where appropriate with response in future.

Fiche: S7318:201-57318:205

scn: $\quad 9104090190$

D.J. Robere, letter forwarding proprietary responses to discussion items of April 3, 1991, GE-NRC Reactor Systems Branch conference all per July 3, 1990, submittal of Amendment 13 to advanced BWR SSAR Chapter 18. Enclosures withheld.

Fiche: 57418:311-57418:315

acn: $\quad 9104150190$

V.M. McCroe, NRC, summary of Fobruary 28, 1991, meeting with GE in Rockville, Maryland regarding GE Advance BWR control room design. List of attendees and meeting agenda enclosed.

Fiche: 57452:184-57452:189

acn: $\quad 9104190303$

G.L. Sozzi, letter forwarding foldout drawing identified for later delivery in 910222 submittal of Amendment 16 to GE advanced BWR SSAR.

Fiche: $\quad$ 57576:104-57576:218

acn: $\quad 9104290285$

P.W. Marriott, GE, letter forwarding responses to open items from March 4 through 6, 1991, meeting on plant systems.

Fiche: $\quad$ 57627:227-57627:314

acn: $\quad 9105030120$

P.W. Marriott, GE, letter forwarding draft amendment to Chapter 12 of advanced BWR SSAR addressing GE responses to discussion items of November 15, 1990, and GENRC Radiation Protection Branch conference call. GE will amend SSAR with changes in future.

Fiche: $\quad 57703: 210-57703: 265$

acn: $\quad 9105100147$

P.W. Marriott, GE, letter forwarding advanced BWR SSAR figures in response to NRC August 15, 1990, letter consisting of NRC Questions 430.243A and 430.239. With five oversize drawings.

Fiche: $\quad$ 57872:249-57872:251

acn: $\quad 9105170100$

P.W. Marriott, GE, letter forwarding modified advanced BWR SSAR proprietary figures regarding NRC Questions 430.243.A and 430.239 of 900815 request for additional information. With seven proprietary oversize drawings. Drawings withheld.

Fiche: 57783:294-57783:295

date: $\quad 910510$ 
P.W. Marriott, GE, letter forwarding responses to GE-NRC materials and chemical engineering branch conference call of April 30, 1991, regarding material selection fracture toughness high tomperature properties and turbine design. Responses will be incorporated in future amendments.

Fiche: $\quad$ 57811:271-57811:282

acn: $\quad 9105160128$

May 10, 1991

May 16, 1991

P.W. Marriott, GE, letter forwarding reeponse to discussion items regarding QA during design and construction per April 12, 1991, conference call with NRC. Response will be incorporated into future amendments.

Fiche: 57796:071-57796:072

acn: $\quad 9105150015$

P.W. Marriott, GE, letter forwarding modifications to Table 5.2-1 of ABWR SSAR eliminating ASME inservice inspection code case N-322 and N-390 incorporated to Regulatory Guide 1.147.

Fiche: $\quad 57870: 309-57870: 313$

acn: $\quad 9105280049$

May 20, 1991

R.C. Mitchell, letter forwarding responses to GE and NRC May 7, 1991, meeting regarding open items on advanced BWR SSAR Chapter 14. Response to open items 2.1.4, 2.1.6, 2.1.7, and 2.1.9 will be transmitted by the end of June.

Fiche: $\quad 57877: 307-57877: 360$

acn: $\quad 9105290118$

May 22, 1991

T.J. Kenyon, NRC, summary of May 14, 1991, meeting with NUMARC, EPRI, GE, ABB-CE, and Westinghouse regarding schedules for review of future LWR projects.

Fiche: $\quad$ 57917:279-57917:334

acn: $\quad 9106040123$

May 22, 1991

T.J. Kenyon, NRC, meeting summary of May 14, 1991, meeting with NUMARC, EPRI, GE, ABB-CE, and Westinghouse regarding schedules for review of future LWR projects.

Fiche: $\quad 57917: 279-57917: 334$

acn: $\quad 9106040123$

June 10, 1991

D. Crutchfield, NRC, letter forwarding draft safety evaluation report regarding review of application for certificate of advanced BWR design. Copies of report sent to ACRS for review and placed in PDR.

Fiche: $\quad$ 58158:082-58159:087

acn: $\quad 9106140092$

June 21, 1991

D. Crutchfield, NRC, letter discussing review of Chapter 12 of advanced BWR SSAR. Recommends that viable options to resolve radiation protection issues be discussed as soon as possible.

Fiche: $\quad$ 58217:338-58217:341

acn: $\quad 9106260266$

June 26, 1991 R.C. Mitchell, letter forwarding responses to discussion items regarding flood protection new and spent fuel storage light load handling system ultimate beat sink turbine building cooling water system reactor SVC water and turbine SVC water system per June 3 and 5, 1991, conference calls.

Fiche: $\quad 58336: 318-58336: 344$

acn: $\quad 9107090128$ 
June 28, 1991

June 28, 1991

June 28, 1991

July 22, 1991

July 26, 1991

July 29, 1991

July 31,1991

August 16, 1991

August 19, 1991

August 20, 1991
RSAR reference safety analysis report and Amendments (RSAR) Amendment 17 to advanced BWR SSAR.

Fiche: $\quad$ 58406:003-58407:228

acn: $\quad 9107150349$

J.S. Charnley, letter submitting Amendment 17 to SSAR including update on HVAC in reactor building update on HVAC in control building fire hazard analysis methodology update and selected responses to SER open items and amendments to Chapter 20.

Fiche: 58406:001-58407:228

acn: $\quad 9107150301$

J.S. Charnley, letter forwarding Amendment 17 to proprietary information to GE advanced BWR SSAR. Enclosures withheld.

Fiche: 58408:044-58408:044

acn: $\quad 9107120057$

D. Crutchfield, NRC, letter requesting list of assumptions used to develop schedules for certification of advanced BWR and standard BWR reactor designs by November 4, 1991.

Fiche: $\quad 58590: 159-58590: 161$

acn: $\quad 9107260038$

J.N. Wilson, NRC, summary of February 5, 1991, meeting with GE in San Jose, California to tour testing and training facilities and to discuss design certification review issues for advanced BWR.

Fiche: $\quad$ 58708:227-58708:277

acn: $\quad 9108080110$

P.W. Marriott, GE, letter forwarding response to radiation protection branch request at GE/NRC July 17, 1991, meeting regarding advanced BWR fuel bundle source term information and geometry of drywell.

Fiche: $\quad$ 58612:356-58612:359

acn: $\quad 9107310180$

V.M. McCree, NRC, letter forwarding summary of issues related to staff review of Chapter 7, "Instrumentation and Control System," advanced BWR SSAR. Information should form basis for timely discussions and meetings to resolve issues.

Fiche: $\quad$ 58700:052-58700:064

acn: $\quad 9108080005$

P.W. Marriott, GE, letter forwarding proprietary advanced BWR documents regarding issues identified in reference to August 8, 1991, draft SER summary for Chapter 7.

Fiche: $\quad 58898: 161-58898: 165$

acn: $\quad 9108220045$

A.E. Rogers, letter forwarding GE proposal pertaining to methodology to confirm adequacy of advanced BWR seismic design.

Fiche: $\quad 58890: 263-58890: 267$

acn: $\quad 9108230259$

D. Crutchfield, NRC, letter forwarding draft SER regarding review of application for certificpition of advanced BWR design. Draft SER discusses results of review of GE standard SAR Chapters 3, 9, 10, 11, and 13.

Fiche: $\quad 58982: 316-58983: 151$

acn: $\quad 9109040463$ 
August 21, 1991

August 28, 1991

August 30, 1991

August 30, 1991

September 4, 1991

September 4, 1991

September 5, 1991

September 6, 1991

September 11, 1991
D. Scaletti, NRC, summary of July 16, 1991, meeting with GE in Rockville, Maryland regarding certification review of ABWR design. Meeting notice agenda and list of attendees enclosed.

Ficho: $\quad$ 58893:028-58893:046

acn: $\quad 9108270045$

R.W. Borchardt, NRC, moeting summary of August 22, 1991, moeting with GE and NUMARC regarding inspections test analysis and acceptance criteria. List of attendees and handouts enclosed.

Fiche: $\quad 59040: 044-59040: 108$

acn: $\quad 9109090074$

P.W. Marriott, GE, letter requesting that F.A. Ross (advanced LWR program manager for DOE) be added to service list. Address listed.

Fiche: $\quad$ 59029:244-59029:244

acn: $\quad 9109050199$

D. Scaletti, NRC, letter forwarding summary of issues developed during course of NRC review of Chapter 18 of SSAR for advanced BWR design. Issues should be resolved prior to issuance of FSAR.

Fiche: $\quad$ 59069:262-59069:269

scn: $\quad 9109110058$

D.J. Robare, letter forwarding GE proprietary responses to advance BWR SSAR

Chapter 18 draft SER open items. Enclosures withheld.

Fiche: $\quad$ 59060:001-59060:001

acn: $\quad 9109100169$

D.J. Robare, letter forwarding proprietary responses to advanced BWR SSAR Chapter 8 draft SER open items. Enclosures withheld.

Fiche: $\quad$ 59051:153-59051:154

acn: $\quad 9109100118$

V.M. McCree, NRC, meeting summary of August 6, 1991, meeting with utilities in Rockville, Maryland regarding status and preliminary findings from staff review of Chapter 19 of GE ABWR SSAR-PRA. Copy of meeting agenda attendees list and handouts enclosed.

Fiche: $\quad$ 59121:272-59121:325

acn: $\quad 9109170308$

D. Scaletti, NRC, letter forwarding summary of issues identified as a result of review of GE application for design certification of advanced BWR including Reactor Systems Branch concerns regarding intersystem LOCAs shutdown risk and BWR stability.

Fiche: $\quad$ 59098:338-59098:344

acn: $\quad 9109120242$

C. Poslusny, letter forwarding information not included in previous letter regarding identification of new issues for GE advanced BWR review.

Fiche: $\quad$ 59118:023-59118:030

acn: $\quad 9109170330$ 
Soptember 11, 1991

September 12, 1991

September 13, 1991

September 16, 1991

September 19, 1991

September 20, 1991

September 20, 1991

September 24, 1991

September 27, 1991

September 27, 1991
C.L. Miller, letter providing industry with NRC initial reaction and comments to draft submittals. Draft ITAAC lacked level of detail and specific accoptance criteria appropriate for inclusion in Tier 1 ITAAC. Without enclosures.

Ficho: 59114:287-59114:287

acn: $\quad 9109160343$

C. Poslusay, letter requesting information regarding identification of design differences between advanced BWR and BWR-6 and resulting changes to draft statistical technical requirements.

Fiche: $\quad$ 59139:063-59139:065

ecn: $\quad 9109180190$

C. Posluany, meeting summaries-internal (non-transcript) summary of August 20, 1991, mooting with GE in San Jose, California regarding piping design for advanced BWR. Viewgraphs enclosed.

Fiche: 59191:144-59191:150

acn: $\quad 9109230068$

D. Crutchfield, NRC, letter informing licensee of three items that may affect NRC schedule for advanced BWR design certification review.

Fiche: $\quad$ 59157:267-59157:269

acn: $\quad 9109200082$

C.L. Miller, letter discussing resolution of issues regarding Chapter 19k of standard SAR for advanced BWR design. Scheduled consistent with resolving issues.

Fiche: $\quad$ 59257:123-59257:127

acn: $\quad 9109300225$

General external technical reports, "Tier 1 Design Certification Material Pilot ITAAC Examples for GE Advanced BWR Design."

Fiche: $\quad$ 59245:270-59245:339

acn: $\quad 9109300071$

P.W. Marriott, GE, letter forwarding, "Tier 1 Design Certification Material Pilot ITAAC Examples for GE Advanced BWR Design."

Fiche: 59245:268-59245:339

acn: $\quad 9109300070$

C. Poslusny, NRC, letter forwarding preliminary staff evaluation of shutdown risk assessment for advanced BWR.

Fiche: 59288:001-59288:006

scn: $\quad 9110030143$

A.E. Rogers, letter forwarding proprietary response to discussion item regarding Amendment 17 to advanced BWR SSAR (Table 1.8-21 Page 1.8-58) which deleted NQA-2 from list of industrial codes and standards applicable to advanced BWR. Response withheld.

Fiche: $\quad 59313: 346-59313: 346$

acn: $\quad 9110070137$

A.E. Rogers, letter forwarding proprietary response to discussion regarding Chapter 19 of draft SER concerning QA program prevention of core damage protection from external threats and ultimate heat sink models and reliability. Response withheld.

Fiche: $\quad$ 59313:347-59313:347

acn: $\quad 9110070107$ 
Appendix C

September 27, 1991

September 30, 1991

October 1, 1991

October 1, 1991

October 1, 1991

October 4, 1991

October 4, 1991

October 9, 1991

October 11, 1991
R.W. Strong, letter forwarding advanced BWR SSAR Chapter 8 status report and closure action plan as followup to September 16 through 18 1991, meetings in San Jose, California.

Fiche: $\quad$ 60211:250-60211:349

acn: $\quad 9201060166$

Text-eafety report-draft SER on Chapter 19 of GE application for certification of advanced BWR design.

Fiche: $\quad$ 59942:119-59942:328

ecn: $\quad 9112100195$

P.W. Marriott, GE, letter forwarding support documents regarding resolution of issues related to Chapter 18 of STD SAR for advanced BWR reactor design per request in September 10 and 11, 1991, meeting in San Jose, California. Enclosures withheld (Ref. 10 CFR 2.790).

Fiche: $\quad$ 59323:354-59323:358

acn: $\quad 9110090173$

P.W. Marriott, GE, letter forwarding proprietary responses to Chapter 18 of SSAR issues per September 10 and 11, 1991, meetings. Enclosures withheld.

Fiche: $\quad$ 59317:035-59317:035

acn: $\quad 9110080063$

J.M. Taylor, NRC, letter informing of intent to issue Chapter 19 of draft SER on GE advanced BWR design. Fiche:59444:004-59444:215

Fiche: $\quad$ 59940:165-59940:166

Fiche: 70988:186-70989:037

Fiche: 71031:001-71031:003

acn: $\quad 9110070046$

D. Crutchfield, NRC, letter forwarding draft SER regarding review of Chapter 7 of licensee application for certification of advanced BWR design.

Fiche: 59445:225-59445:320

Fiche: 59444:001-003

acn: $\quad 9110250101$

D. Crutchfield, NRC, letter forwarding DSER regarding review of application for certification of advanced BWR design. Report discusses results of review of licensee SSAR Chapter 19, "Response to Severe Accident Policy Statement."

Fiche: 59444:001-59444:003

Fiche: $\quad 59942: 116-59942: 328$

acn: $\quad 9110250061$

P.W. Marriott, GE, letter forwarding responses to enable resolution of issues regarding advanced BWR SER Chapters 1 through 6 and 17 (SECY-91-152). Issues includes control room habitability reactor building cooling water and TMI Action Item II.k.3.18 regarding ADS logic.

Fiche: 59403:247-59403:260

acn: $\quad 9110170138$

P.W. Marriott, GE, letter forwarding proprietary information to advanced BWR SSAR amendment 18 consisting of sections of Chapters 9, 11, 19, and 20. Information withheld.

Fiche: $\quad$ 59407:339-59407:341

acn: $\quad 9110180212$ 
October 11, 1991

October 11, 1991

October 11, 1991

October 15, 1991

October 16, 1991

October 22, 1991

October 23, 1991

October 24, 1991

October 24, 1991
General external technical reports--Amendment 18 to advanced BWR SSAR Chapters 1 through 7, 9 through 12, and 14 through 20.

Fiche: 59416:007-59417:011

acn: $\quad 9110180201$

P.W. Marriott, GE, letter forwarding nonproprietary information to advanced BWR SSAR amendment 18 consisting of section of Chupters 1 through 7, 9 through 12, and 14 through 20 regarding site characteristics design structures components equipment and systems and RCS and connected systems.

Fiche: $\quad$ 59416:001-59417:011

acn: $\quad 9110180195$

P.W. Marriott, GE, letter forwarding responses inadvortently omitted from October 9 , 1991, transmittal of licensee responses to resolution of issues regarding advanced BWR SER Chapters 1-6 and 7 (SECY-91-152).

Fiche: 59406:353-59406:358

acn: $\quad 9110180135$

J.M. Taylor, NRC, letter informing Commission of staff intent to issue Section 18 of draft SER on GE advanced BWR design.

Fiche: 59680:014-59680:085

acn: $\quad 9110300123$

D. Scaletti, NRC, meeting summaries-internal (non-transcript) summary of September 10 and 11, 1991, meetings with GE in San Jose, California regarding advanced BWR human factors engineering design.

Fiche: $\quad$ 59419:199-59419:224

acn: $\quad 9110210188$

R. Stransky, summary of August 29, 1991, meeting with GE and BWR utilities regarding licensing topical report NEDC-31984p, "Generic Evaluations of GE BWR Power Uprate." List of meeting attendees and proprietary viewgraphs enclosed.

Proprietary viewgraphs withheld.

Fiche: $\quad 59570: 056-59570: 058$

acn: $\quad 9111080104$

D. Crutchfield, NRC, letter providing initial reaction and general comments on proposed preliminary review of pilot inspection test analysis and acceptance criteria (ITAAC) for advanced BWR submittal. Proposal lacks level of detail and acceptance criteria for inclusion in material.

Fiche: $\quad 59511: 168-59511: 171$

acn: $\quad 9111010275$

P.W. Marriott, GE, letter forwarding, "Advanced BWR Control Room Design Implementation Process" per September 1991, meetings in San Jose, California regarding Chapter 18 of advanced BWR STD SAR. Table and figures withheld.

Fiche: 59483:283-59483:287

acn: $\quad 9110300089$

P.W. Marriott, GE, letter forwarding proprietary portion of comprehensive program plan for design development implementation and validation of ABWR man-machine interface. Enclosures withheld (Ref. 10 CFR 2.790).

Fiche: 59461:171-59461:174

acn: $\quad 9110280363$ 
Appendix C

October 25, 1991

J.S. Charnley, letter forwarding report providing update of in-reactor surveillance programs and overall GE BWR fuel experience through December 1990.

Fiche: 59565:001-59565:013

acn: $\quad 9111060207$

October 25, 1991

P.W. Marriott, GE, letter forwarding additional documents in response to NRC August 30, 1991, letter regarding resolution of issues related to Chapter 18 of SSAR for advanced BWR design. Documents withhold.

Fiche: $\quad$ 59502:121-59502:124

acn: $\quad 9110300260$

October 29, 1991

C. Poslusny, NRC, summary of October 8 through 10, 1991, meeting with GE in San Jose, California regarding open issues identified by NRC staff review of licensee SSAR for advanced BWR. List of attendees and moeting agenda enclosed.'

Fiche: 59640:094-59640:182

acn: $\quad 9111130187$

October 30, 1991

D. Crutchfield, NRC, letter forwarding DSE report regarding reviow of licensee applications for certification of advanced BWR design attached to enclosure SECY-91320. Without SECY.

Fiche: $\quad 59680: 012-59680: 085$

acn: $\quad 9111140145$

October 31, 1991

T.H. Boyce, NRC, summary of October 16 and 17, 1991, meetings with utilities in Rockville, Maryland regarding issues concerning inspections, tests, analyses, and acceptance criteria for advanced BWR. List of meeting attendees enclosed.

Fiche: 59546:001-59546:006

acn: $\quad 9111060310$

October 31, 1991 J.M. Taylor, NRC, letter informing Commission of NRC intent to issue selected sections of draft SER on GE advanced BWR design.

Fiche: 59987:118-59988:047

acn: $\quad 9112130022$

November 1, 1991

D.J. Robare, letter forwarding proprietary GE responses to staff position regarding GE BWR power upgrade program dated September 30, 1991. Responses in reference to licensing topical report NEDC-31897p-1, "Generic Evaluations of GE BWR Power Uprate June 1991." Responses withheld.

November 1, 1991

P.W. Marriott, letter forwarding summary of major advanced BWR design differences assessment of how'TS differ from improved TS including summary of new different or inapplicable and example of how TS would be written where TS differ from improved TS.

Fiche: $\quad 59565: 111-59565: 124$

acn: $\quad 9111070083$

November 7, 1991

P.W. Marriott, GE, letter forwarding response to discussion Item 7, September 6, 1991, conference call regarding rod block algorithm and setpoint.

Fiche: $\quad$ 59649:263-59649:266

acn: $\quad 9111120264$ 
November 12, 1991

November 12, 1991

November 13, 1991

November 18, 1991

November 21, 1991

November 25, 1991

November 27, 1991

November 27, 1991

December 2, 1991
P.W. Marriott, GE, letter forwarding draft writeup for fire protection probabilistic risk assessment requested in draft SER on advanced BWR probabilistic risk assessment. GE will amend SSAR to include information when finalized.

Fiche: $\quad$ 59790:263-59790:280

scn: $\quad 9111190373$

P.W. Marriott, GE, letter forwarding proprietary draft writeup for fire protection PRA as requeeted in draft SER on advanced BWR PRA per SECY-91-309 dated October 1, 1991. Enclosure withhold.

Fiche: 59839:012-59839:015

ecn: $\quad 9111250054$

D. Crutchfield, NRC, letter submitting scheduled projection for closure of draft SER isstres. Process involves frequent and effective dialogue and licensee near-term actions. Fiche: $\quad$ 59879:131-59879:135

acn: $\quad 9112030458$

V.M. McCree, NRC, letter forwarding draft of safety evaluation regarding review of GE advanced BWR SSAR Chapter 19, "Response to Severe Accident Policy

Statement." Proprietary version of draft SE transmitted to licensee on October 4, 1991. Fiche: $\quad$ 59912:067-59912:282

acn: $\quad 9112060224$

D. Crutchfield, NRC, requests submittal of design certification of assess severe accident mitigation design alternatives and impact on safety of design.

Fiche: 59918:351-59918:354

acn: $\quad 9112060223$

A.E. Rogers, letter forwarding tables regarding significant new open issues included in final draft SER significant open items included in all draft SERs GE future submittals and proposed issues for discussion at December meeting per NRC November 13, 1991, letter.

Fiche: $\quad 59867: 330-59867: 337$

acn: $\quad 9112020128$

A.E. Rogers, letter forwarding proprietary responses to Open Issues 8.3.3.6 and 8.3.5 for advanced BWR SSAR Chapter 8 per commitment at September 16 through 18, 1991, moeting in San Jose. Enclosures withheld.

Fiche: 59953:102-59953:102

acn: $\quad 9112090242$

A.E. Rogers, letter forwarding responses to open issues in GE advanced BWR SSAR Chapter 8 regarding offsite power and protective systems for reactor internal pumps per September 16 through 18, 1991, meeting with NRC. Proprietary versions of response withheld.

Fiche: 59954:077-59954:217

acn: $\quad 9112090240$

P.W. Marriott, GE, letter describing plan for submitting advanced BWR technical specs to NRC per November 8, 1991, meeting. First submittal of noninstrumentation and control systems will be submitted by December 13, 1991. Third submittal regarding 65 unchanged 1 COS will be submitted by January 31, 1992.

Fiche: 59954:260-59954:262

acn: $\quad 9112090224$ 
V.M. McCree, NRC, letter requesting listed information to complete review of advanced BWR SSAR regarding incorporation of operating information into design. Response requested by January 6, 1992.

Fiche: $\quad$ 59984:335-59984:337

acn: $\quad 9112130052$

December 9, 1991

December 9, 1991

December 12, 1991

December 12, 1991

December 13, 1991

December 13, 1991

December 13, 1991

December 16, 1991
R.L. Nease, NRC, meeting summaries-internal (non-transcript) summary of meeting with GE regarding forthcoming submittal of advanced BWR technical specs for NRC staff review.

Fiche: $\quad 60097: 309-60097: 311$

acn:9112240035

C. Poslusny, NRC, meeting summaries-internal (non-transcript) summary of December 17 through 19, 1991, meeting with GE in San Jose, California regarding open issues concerning Chapter 9 of GE SSAR on electrical systems design.

Fiche: $\quad$ 60097:312-60097:316

acn: $\quad 9112240028$

Text-specifications and test reports--proposed advanced BWR technical specs covering control rod accumulators reactor internal pumps - operating RHR suppression pool cooling ECCS - operating UHS and reactor building cooling water and reactor building SVC water system.

Fiche: $\quad 60088 ; 173-60088: 201$

acn: $\quad 9112190169$

P.W. Marriott, letter forwarding proposed advanced BWR technical specifications per vendor December 2, 1991, letter to NRC. Specifications will be documented via amendment to Chapter 16 of advanced BWR SSAR once specifications are finalized. Fiche: 60088:172-60088:201 acn: $\quad 9112190166$

P.W. Marriott, GE, letter forwarding sections of Chapter 9, "Auxiliary System and Chapter 18 - Human Factors Engineering," of SSAR for advanced BWR Amendment 19 including update of control building fire protection drawings. Enclosures withheld.

Fiche: 60083:043-60083:043

acn: $\quad 9112230044$

Text-safety report--Amendment 19 to advanced BWR SSAR.

Fiche: $\quad 60097: 318-60098: 006$

acn: $\quad 9112190171$

P.W. Marriott, GE, letter forwarding Amendment 19 to advanced BWR SSAR.

Fiche: 60097:317-60098:006

acn: $\quad 9112190168$

R.L. Nease, NRC, meetings summaries-internal (non-transcript) summary of December 6, 1991, meeting with GE in Rockville, Maryland regarding ODYNA and REDYA computer codes that GE is using for transient analyses of advanced BWR. Attendees list and GE presentation enclosed.

Fiche: 60109:171-60109:185

acn: $\quad 9112260191$ 
Docomber 16, 1991

December 17, 1991

December 19, 1991

December 19, 1991

December 19, 1991

December 19, 1991

December 19, 1991

December 20, 1991

December 30, 1991

December 30, 1991
R.L. Neaso, NRC, moeting summaries-internal (non-transcript) summary of December 5, 1991, meeting with GE in Rockville, Maryland regarding current design of advanced BWR. List of attendees and GE presentation material enclosed.

Fiche: $\quad 6016 \%: 065-60165: 182$

acn: $\quad 9201020127$

J. Palomar, letter forwarding text-procurement and contracts draft of, "Defense-in-Depth and Diversity Assessment of GE Advanced BWR Protection System."

Fiche: $\quad$ 60341:086-60341:208

acn: $\quad 9201220287$

General external technical reports, "Advanced BWR Design Reliability Assurance Program."

Fiche: 60193:201-60193:228

acn: $\quad 9201030280$

P.W. Marriott, GE, letter forwarding nonproprietary responses to resolution of issues regarding advanced BWR draft SER.

Fiche: 60131:153-60131:181

acn: $\quad 9112260268$

P.W. Marriott, GE, letter forwarding proprietary responses to resolution of issues regarding advanced BWR draft SER.

Fiche: 60131:182-60131:182

acn: $\quad 9112260264$

Text safety report--nonproprietary Revision B to update App 9a, "Reactor Building Fire Hazard Analysis."

Fiche: 60102:287-60102:301

acn: $\quad 9112260100$

P.W. Marriott, GE, letter forwarding proprietary and nonproprietary versions of Revision B to update of Appendix 9a, "Reactor Building Fire Hazard Analysis."

Fiche: $\quad$ 60102:286-60102:301

acn: $\quad 9112260094$

P.W. Marriott, GE, letter confirming that licensee advanced BWR application should be processed as application for Part 52 Final Design Approval and Subsequent Design

Certification per 10 CFR 52.45 .

Fiche: 60224:094-60224:094

acn: $\quad 9201070246$

R.C. Pierson, NRC, letter forwarding Generic Letter 82-39, "Problems with Submittals of 10 CFR 73.21 Safeguards Information for Licensing Review."

Fiche: $\quad$ 60237:180-60237:184

acn: $\quad 9201070307$

V.M. McCree, NRC, letter forwarding draft NUREG-CR-567P BNL-NUREG-52276p, "Review of Advanced BWR Probabilistic Risk Assessment Vol. 1: Internal and External Events Core Damage and Frequency," and proprietary Vol. 2 of subject report. Volume withheld.

Fiche: $\quad 60281: 016-60281: 320$

acn: $\quad 9201080121$ 
Appendix C

December 31, 1991

A.J. James, letter forwarding general extornal technical reports, "Advanced BWR Deaign Certification Guidelines for Preparation of Inspection Teats Analyais and Acceptunce Criteria (ITAAC)."

Ficho: 60006:084-60006:140

scn: $\quad 9112160050$

January 2, 1992

January 3, 1992

V.M. McCreo, NRC, letter providing supply list of shutdown risk iswes applicable to GB advanced BWR.

Fiche: $\quad$ 60226:354-60226:360

ecn: $\quad 9201080230$

January 3, 1992

C. Poslusny, lotter forwarding mooting summary of Docember 9 and 10, 1991, with utilities in San Joee, California regarding open isenes based on NRC staff roview of licenseo SSAR for advanced BWR. List of attendees and meoting agenda enclosed.

Fiche: 60302:114-60302:313

scn: $\quad 9201130174$

P.W. Marriott, GE, letter forwarding proprietary NEDE-30822, "User Teating of REDYA01 Computer Program," and NEDE-30690, "REDYA01 Technical Deecription," to support January 1992, ODYNA-REDYA Audit. Reports withhold.

Fiche: $\quad 60334: 178-60334: 181$

acn: $\quad 9201150127$

January 6, 1992

P.W. Marriott, GE, letter forwarding response to NRC request for additional information regarding incorporation of operating experience in advanced BWR.

Ficho: $\quad 60240: 059-60240: 074$

scn: $\quad 9201080099$

January 6, 1992

January 6, 1992

P.W. Marriott, GE, letter forwarding proprietary tables to App $18 \mathrm{f}$ to Chapter 18 regarding human factors engircering. GE will amend SSAR to includo subject information in future amendments. Enclosure withheld.

Fiche: $\quad 60334: 182-60334: 185$

acn: $\quad 9201150092$

P.W. Marriott, GE, letter forwarding response to issue raised at GE/NRC Decomber 9 and 10, 1991, meetings regarding inservice inspection of requests for reactor pressure vessel bottom head weld and reactor pressure vessel bottom head-to-shell weld.

Fiche: $\quad 60282: 345-60282: 360$

acn: $\quad 9201130255$

January 9, 1992

C. Poslusny, NRC, letter forwarding meeting summaries-internal (non-transcript) summary of November 12, 1991, meeting with UNTIL regarding engineering design issues for advanced BWR. List of attendees enclosed.

Fiche: 60261:350-60261:358

January 10, 1992

C. Poslusny, NRC, letter discussing staff effort to develop final SER Section discussing design aspects of advanced BWR. Additional information requested. Specific questions enclosed. Response requested no later than March 1, 1992, with preliminary conference call on January 22, 1992.

Fiche: 60329:127-60329:142

acn: $\quad 9201170191$ 
January 10, 1992

Jenuary 10, 1992

January 15, 1992

January 16, 1992

January 16, 1992

January 17, 1992

Junuary 17, 1992

January 17, 1992

January 17,1992
P.W. Marriott, GE, letter forwarding responses to Agenda Itom 12 discuseed during November 20 and 21, 1991, meeting with Reactor Syatems Branch of NRC. Reeponses withhold.

Fiche: 60332:103-60332:106

sen: $\quad 9201160227$

P.W. Marriott, GE, letter forwarding reeponse to Agenda Items 1, 5, 9, and 16 diecuseed at OB/NRC Reactor System Branch November 20 and 21, 1991, moetings. Itoms include stability performence in normal operating region loss of AC power and loss of feedwater hearing transient.

Ficho: 60332:065-60332:077

acn: $\quad 9201160018$

C. Poslueny, NRC, lotter forwarding draft document on Dofenso-in-Depth and Diversity Ascesement of GB advanced BWR protection syetem for reviow. Requests comments regarding sccuracy of report treatmeat of Systems Reactions and Design Basis Events by Fobruary 10, 1992.

Fiche: 60341:081-60341:208

acn: $\quad 9201220274$

R.L. Nease, NRC, lotter forwarding, "Component Failure Data Handbook," tochnical evaluation report. Handbook contains genoric component failure data and orror factors. Fiche: 60515:004-60515:171 acn: $\quad 9201230259$

C. Poslueny, NRC, letter forwarding information omitted from January 16, 1992, submittal consisting of enclosure with review guidance and two enclosures with queations to support closure of severe accident issues for advanced BWR.

Fiche: 60356:312-60356:316

acn: $\quad 9201230245$

R.L. Nease, NRC, letter forwarding draft NUREG-1449, "NRC Staff Evaluation of Shutdown and Low Power Operation." Final version of NUREG-1449 scheduled to bo issued to Commission by carly Pobruary 1992.

Fiche: $\quad$ 60341:209-60342:297

acn: $\quad 9201220280$

C. Poslusny, NRC, forwarding summary of Jenuary 14, 1992, moeting with UNTIL regarding draft of advanced BWR design reliability prognm dated December 19, 1991. Draft and list of meeting attendees enclosed.

Fiche: 60402:265-60402:297

acn: $\quad 9201290084$

General external technical reports, "Advanced BWR design certification generic ITAAC for Catogory 1 Structures Position Paper."

Fiche: $\quad$ 60378:324-60378:355

acn: $\quad 9201240141$

General external technical reports, "Tier 1 Design Certification Material Pilot ITAAC Examples for GE Advanced BWR Design."

Fiche: 60378:222-60378:323

acn: $\quad 9201240140$ 
Appendix C

January 17, 1992

P.W. Marriott, GE, letter forwarding, "Tier 1 Design Certification MATL Pilot ITAAC Examples for GE Advanced BWR Design" and "Advanced BWR Design Certification Generic ITAAC for Soismic Category 1 Structuros Position Paper."

Ficho: 60378:220-60378:355

January 17, 1992

C. Poaluany, NRC, letter forwarding NRR Advanced Reactor Division open item tracking system report dated January 8, 1992.

Ficho: 60356:329-60356:353

ecn: $\quad 9201230253$

January 20, 1992

January 22, 1992

R.L. Nease, NRC, letter forwarding plan and agenda for January 28 through 30, 1992, audit of GE ODYNO and REDYA transient analysis codes.

Fiche: $\quad$ 60379:332-60379:335

acn: $\quad 9201280134$

S.S. Dua, letter forwarding response to open issue 3 of SECY-91-153 regarding main steamlino seismic classification including static design procedure to be utilized in evaluation of seismic capability of condenser anchorage and turbine building.

Fiche: 60397:150-60397:161

scn: $\quad 9201270140$

January 22, 1992

D. Crutchfield, NRC, letter discussing responses to NRC open items on advanced BWR SSAR Chapter 14. Requests that until expedite responses to open items identified in November 5, 1991, DSER.

Fiche: $\quad$ 60403:238-60403:240

January 28, 1992

C. Poslusny, NRC, letter providing comments on information included in SSAR regarding control rod design criteria and requests that information be provided to staff.

Fiche: 60481:049-60481:051

acn: $\quad 9202050431$

January 31, 1992

P.W. Marriott, GE, letter forwarding proprietary NEDC-30032, "Joint Study Final Report." Joint study with regard to study (ii) related to advanced BWR thermal margin during rapid coastdown 820401-830331. Report withheld.

Fiche: 60492:050-60492:053

acn: $\quad 9202040413$

Fobruary 3, 1992

R.C. Mitchell, letter forwarding 24 proprietary oversized drawings regarding advanced BWR piping and instrumentation and process flow. With 23 oversize drawings.

Drawings withheld.

Fiche: $\quad$ 60688:293-60688:294

acn: $\quad 9202060278$

February 3, 1992

R.C. Mitchell, letter forwarding letter with updated advanced BWR piping and instrumentation and process flow drawings. W-116 oversized drawings.

Fiche: 60583:001-60583:002

acn: $\quad 9202110336$

February 3, 1992

R.C. Mitchell, letter forwarding letter responding to leak before break issue addressed in December 9 and 10, 1991, GE/NRC meeting. Advises that GE intends to amend SSAR with response in future amendment.

Fiche: $\quad 60574: 178-60574: 262$

acn: $\quad 9202110324$ 
Fobruary 3, 1992

Fobruary 3, 1992

Fobruary 10, 1992

February 11, 1992

February 13, 1992

February 14, 1992

February 14, 1992

February 17, 1992

February 18, 1992
R.C. Mitchell, letter forwarding nonproprietary reeponses to additional items of concern noted in draft SER for Chapter 7. Advises that GE will amend advanced BWR SSAR with responses in future amendments.

Fiche: $\quad$ 60574:133-60574:177

acn: $\quad 9202110316$

R.C. Mitchell, letter forwarding proprietary responses to additional information noted in October 4, 1991, draft SER for Chapter 7. Responses are cross referenced with summary item number corresponding to review meeting in San Jose, California on August 7 and 8, 1991. Responses withheld.

Fiche: 60579:298-60579:298

acn: $\quad 9202110221$

P.W. Marriott, OE, letter forwarding responses to January 10, 1992, 16 requests for additional information on advanced BWR design for severe accidents.

Fiche: 60627:101-60627:124

acn: $\quad 9202190376$

P.W. Marriott, GE, letter forwarding response to performance and quality evaluation branch open items on advanced BWR standard SAR Chapter 14.

Fiche: $\quad 60677: 256-60677: 257$

acn: $\quad 9202190379$

P.W. Marriott, GE, letter forwarding proprietary Appendix 18f, "Emergency Operation Information and Controls, " to Chapter 18, "Human Factors Engineers," of advanced BWR STD SAR covering control room inventory. Appendix $18 \mathrm{f}$ withheld.

Fiche: $\quad$ 60627:070-60627:070

acn: $\quad 9202190366$

P.W. Marriott, GE, letter forwarding nonproprietary portion of GE responses to agenda items discussed during November 20 and 21, 1991, meeting with NRC Reactor Systems Branch regarding standby liquid control system instrumentation and controls.

Fiche: $\quad$ 60627:073-60627:100

acn: $\quad 9202.190343$

P.W. Marriott, GE, letter forwarding proprietary portion of GE response to agenda items discussed during November 20-21, 1991, meeting with NRC Reactor Systems Branch. Response withheld

Fiche: 60627:072-60627:072

acn: $\quad 9202190325$

T.J. O'Neil, letter forwarding proprietary revised Appendix 18e, "Advanced BWR ManMachine Interface System Design and Implementation Process," of advanced BWR

SSAR, App. withbeld.

Fiche: $\quad$ 60854:350-60854:350

acn: $\quad 9203030270$

V.M. McCree, meeting summaries-internal (non-transcript) summary of November 20, 1991, meeting with GE in San Jose, California to discuss open items for staff review of advanced BWR Std SAR.

Fiche: $\quad$ 60710:066-60710:134

acn: $\quad 9202260310$ 
Appendix C

February 19, 1992

Pobruary 19, 1992

February 19, 1992

February 20, 1992

February 20, 1992

February 24, 1992

February 25, 1992

February 25, 1992

February 25, 1992
R.L. Neaso, letter forwarding internal flooding analysis. Metholodology used is combination of qualitative and quantitutive analyese that looks for vulnerabilitios to internal floods that could cause core damage.

Fiche: 60705:305-60706:122

ecn: $\quad 9202260235$

D. Crutchfield, NRC, letter requeating proposed advanced BWR TS significantly different from BWR-6 TS on computer diek in Wordperfect 5.1 format and olectronic mark-up of NUREG-1434 parts which require only minor revisions to be tailored to advenced BWR design.

Ficho: $\quad$ 60705:286-60705:288

ecn: $\quad 9202260214$

G.W. Ehlert, letter forwarding oxtornal tochnical reports on, "Radwasto Building

Seismic Analysis."

Ficho: $\quad 60827: 141-60827: 149$

acn: $\quad 9203050230$

R.L. Nease, NRC, moeting summaries-internal (non-transcript) summary of January l, 1992, meeting with $O E$ in Rockville, Maryland regarding status of PRA sensitivity and uncertainly analyses for advanced BWR. List of attendees and GE handouts enclosed.

Fiche: $\quad 60726: 184-60726: 232$

acn: $\quad 9202280069$

P.W. Marriott, GE, letter forwarding discussion of differences between US advanced BWR and K-6-7 project. Advanced BWR design under review for differences to K-6-7 and additional differences will bo included in future SS $n R$ Amendment.

Fiche: $\quad$ 60752:062-60752:070

ocn: $\quad 9202270241$

P.W. Marriott, GE, letter forwarding draft of Revision 0, "Advanced BWR SSAR Main Steam Feedwater and SRVDL Piping Design Criteria and Analysis Methods," and draft Revision 0 to, "Advanced BWR Feedwater Loop and Piping and Equipment Loads," per GE/NRC February 9 and 10, 1991, meeting.

Fiche: 60782:304-60783:029

acn: $\quad 9203030235$

P.W. Marriott, GE, letter forwarding App 19P to Chapter 19 of "Evaluation of Potential Mods to Advanced BWR Design."

Fiche: $\quad$ 60751:289-60751:315

acn: $\quad 9202260157$

R. Nease, NRC, letter forwarding proprietary Revision R-O to "Advanced BWR Project Common Engineering Work Plan." Plan withheld.

Fiche: $\quad$ 60782:299-60782:299

acn: $\quad 9203020112$

P.W. Marriott, letter requesting addition of listed individual to advanced BWR document distribution list.

Fiche: $\quad 60786: 321-60786: 321$

acn: $\quad 9202280354$ 
February 25, 1992

February 25, 1992

February 25, 1992

February 26, 1992

February 26, 1992

February 29, 1992

February 29, 1992

March 3, 1992

March 3, 1992

March 4, 1992
C. Poslusny, NRC, meeting summaries-internal (non-transcript) summary of October 24, 1991, moeting with GE in Rockville, Maryland regarding open issues in several areas concerning review of advanced BWR SSAR.

Fiche: $\quad$ 60734:284-60734:288

acn: $\quad 9202280344$

R. Nease, NRC, letter forwarding proprietary summary of January 27,1992 , telcon with NRC and Brookhaven Laboratory to clarify aspects of human factors review of advanced BWR, specifically review of design implementation process. Summary withheld.

Fiche: $\quad 60854: 348-60854: 348$

acn: $\quad 9203030287$

R. Nease, NRC, forwarding proprietary revised Appendix 18e, "Advanced BWR ManMachine Interface System Design and Implementation Process," of advanced BWR

SSAR. App withheld.

Fiche: $\quad$ 60854:349-60854:350

acn: $\quad 9203030268$

R.L. Nease, memorandum forwarding proprietary summary of NRC/GE January 7, 1992, meeting on advanced BWR SSAR Chapter 18. Meeting summary withheld.

Fiche: $\quad$ 60778:051-60778:054

acn: $\quad 9202270211$

V.M. McCree, NRC, letter forwarding corrected list of attendees for February 18, 1992, summary of meeting held on November 20 and 21, 1991.

Fiche: $\quad$ 60772:204-60772:206

acn: $\quad 9203030344$

M. Herzog, forwarding report draft Revision 0 to, "Advanced BWR Feedwater Loop a Piping and Equipment Loads."

Fiche: $\quad$ 60782:339-60783:029

acn: $\quad 9203030253$

M. Herzog, forwarding report draft Revision 0 to, "Advanced BWR SSAR Main Steam Feedwater and SRVDL Piping System Design Criteria and Analysis Methods."

Fiche: $\quad$ 60782:305-60782:338

acn: $\quad 9203030246$

A.E. Rogers, forwarding report, "Radwaste Building Seismic Analysis." Informs that GE intends to amend SSAR with subject analysis in future amendments.

Fiche: $\quad 60827: 140-60827: 149$

acn: $\quad 9203050228$

R.C. Pierson, NRC, letter submitting near term actions to facilitate issue resolution regarding advanced BWR probabilistic risk assessment

Fiche: $\quad 60811: 195-60811: 197$

acn: $\quad 9203050165$

R.C. Pierson, letter forwarding summary of NRC February 10 through 12, 1992, audit of advanced BWR RPV internals. Lists two GE commitments.

Fiche: $\quad$ 60839:113-60839:131

acn: $\quad 9203060154$ 
March 5, 1992

March 5, 1992

March 9, 1992

March 10, 1992

March 11, 1992

March 11, 1992

March 11, 1992

March 11, 1992

March 13, 1992
A.E. Rogers, letter forwarding Revision B to 23(a)6100(aq) Section 17.3 regarding responses to request for resolution of issues related to reliability assurance program (RAP). Subject responses will be included as amendment to advanced BWR SSAR in future.

Fiche: $\quad 60898: 283-60898: 304$

acn: $\quad 9203110132$

A.E. Rogers, letter forwarding Revision B to 23a6100aq Section 17.3 regarding responses to request for resolution of issues related to reliability assurance program (RAP). Subject responses will be included as amendment to advanced BWR SSAR in future.

Fiche: $\quad$ 60898:283-60898:304

acn: $\quad 9203110132$

R.C. Mitchell, letter summarizing staff position regarding NRC conference call on DSER comments to advanced BWR SSAR ISI requirements.

Fiche: 60930:048-60930:049

acn: $\quad 9203120371$

Meeting summaries internal (non-transcript) summary of February 28, 1992, meeting with GE in Rockville, Maryland regarding open items in advanced BWR review concerning postulated trip of all reactor internal pumps and postulated command mode failure of pressure regulator to down scale position.

Fiche: 60963:309-60963:321

acn: $\quad 9203170131$

R.C. Mitchell, letter forwarding draft Revision 0 to, "Advanced BWR SRVDL Wetwell Piping Stress Analysis Design Report," and draft Revision 0 to design report, "Main Steamline A \& Safety Relief Valve Discharge Piping Stress Analysis," per December 9 and 10, 1991, GE/NRC meeting.

Fiche: $\quad$ 60992:037-60992:245

acn: $\quad 9203180162$

R.C. Mitchell, letter forwarding responses to resolution of issues related to advanced BWR draft SER Chapters 1, 2, 3, 5, 6, 9, 10, 12, 13, 14 and 15 (SECY-91-355).

Fiche: $\quad 60991: 162-60991: 338$

acn: $\quad 9203180156$

R.C. Mitchell, letter forwarding proprietary responses to issues regarding Sections 9.3, 9.5, and 11.2 of advanced BWR SSAR. Responses reflect corrections and additions to earlier proprietary submitals. Responses withheld.

Fiche: 60991:161-60991:161

acn: $\quad 9203180147$

P.W. Marriott, letter forwarding piping design inspections, tests, analyses, and acceptance criteria (ITAAC). Piping design ITAAC will be included as part of generic ITAAC.

Fiche: $\quad$ 60992:321-60992:327

acn: $\quad 9203180142$

P.W. Marriott, GE, letter forwarding proprietary Amendment 20 to advanced BWR SSAR. Report withheld.

Fiche: $\quad$ 60998:347-60998:347

acn: $\quad 9203200342$ 
March 13, 1992

March 13, 1992

March 13, 1992

March 25, 1992

March 30, 1992

March 31, 1992

March 31, 1992

April 1, 1992

April 1, 1992

April 1, 1992
P.W. Marriott, GE, letter forwarding nonproprietary Amendment 20 to advanced BWR SSAR.

Fiche: 61061:001-61062:128

acn: $\quad 9203200337$

J.N. Wilson, Federal Register notices - notice of receipt of application for design certification.

Fiche: $\quad$ 60982:349-60982:349

acn: $\quad 9203190450$

D. Crutchfield, NRC, letter discussing December 20, 1991, request for application for approval of advanced BWR design be considered as application for Part 52 design approval and subsequent design certification. Notice of receipt of application for design certification enclosed.

Fiche: $\quad$ 60982:346-60982:349

acn: $\quad 9203190446$

P.W. Marriott, GE, letter forwarding revisions to Appendix 18a, 18b, and 18d to Chaptir 18 of advanced BWR SSAR in reference to December 13, 1991, submittal of Amendment 19 to advanced BWR SSAR. Revisions withheld.

Fiche: 61211:072-61211:072

acn: $\quad 9204010120$

General external technical reports--advanced BWR design document Section 3.7, "Radiation Protection," Section 12.3, "Radiation Protection Design Features," and Section 12a.1, "Calculation of Airborne Radionuclides."

Fiche: 61791:097-61791:231

acn: $\quad 9205200194$

Text-safety report--"Tier 1 Design Certification Material for GE Advanced BWR Design - Stage 2 Submittal."

Fiche: 61273:181-61274:223

acn: $\quad 9204080070$

M.L. Scott, letter contract NRC-03-89-027 awarding Task Order 32, "Design Process Inspection - GE Advanced Boiling Water Reactor," to "Nuclear Power Reactor Operations Modifications and Maintenance Inspection Services."

Fiche: 61320:101-61320:106

acn: $\quad 9204130313$

P.W. Marriott, GE, letter forwarding modifications supporting main steamline seismic classification.

Fiche: $\quad 61298: 269-61298: 271$

acn: $\quad 9204080007$

T.H. Boyce, NRC, meeting summary of February 27, 1992, meeting with GE Nuclear Energy in Rockville, Maryland. Topics discussed included interfaces and inspection analyses and acceptance criteria for advanced BWR.

Fiche: $\quad 61287: 105-61287: 124$

acn: $\quad 9204090336$

G. Kelly, letter forwarding clarification of Confirmatory Item C-O1.

Fiche: 61463:069-61463:070

acn: $\quad 92 \dot{u} 4270112$ 
April 2, 1992

April 2, 1992

April 2, 1992

April 3, 1992

April 3, 1992

April 6, 1992

April 6, 1992

April 7, 1992

April 8, 1992
P.W. Marriott, GE, letter forwarding proprietary GE responses to resolution of selected issues regarding advanced BWR DSER Chapter 19 (SECY-91-309). Report withheld.

Fiche: 61271:194-61271:194

acn: $\quad 9204060391$

R.C. Pierson, NRC, letter requesting review of enclosed advanced BWR TS indicating changes necessary to properly reflect advanced BWR \& design and safety analyses.

Fiche: 61293:092-61293:162

acn: $\quad 9204100376$

B.J. DuBose, notification of contract execution awarding Task Order 32, "Design Process Inspection - GE Advanced Boiling Water Reactor," to, "Nuclear Power Reactor Operations Modifications and Maintenance Inspection Services."

Fiche: $\quad 61320: 100-61320: 106$

acn: $\quad 9204130309$

P.W. Marriott, GE, letter forwanding nonproprietary and proprietary responses to resolution of issues related to Chapter 8 of advanced BWR DSER (SECY-91-355).

Proprietary responses withheld.

Fiche: 61364:100-61364:235

acn: $\quad 9204130074$

P.W. Marriott, GE, letter forwarding proprietary responses to resolution of issues related to Chapter 8 of advanced BWR DSER (SECY-91-355). Enclosures withheld.

Fiche: 61330:344-61330:344

acn: $\quad 9204130069$

P.W. Marriott, GE, letter forwarding, "Tier 1 Design Certification for GE Advanced BWR Design - Stage 2 Submittal," including descriptions and proposed inspections, tests, analyses, and acceptance criteria (ITAAC) for $\mathbf{4 0}$ advanced BWR systems. Lists information not covered by report.

Fiche: $\quad$ 61273:179-61274:223

acn: $\quad 9204080069$

P.W. Marriott, GE, letter forwarding GE responses to resolution of issues related to Chapter 15 of advanced BWR Draft SER incorporating responses to NRC staff comments and to outstanding issues 136 and 139.

Fiche: $\quad$ 61329:292-61329:341

acn: $\quad 9204130227$

G. Kelly, letter forwarding instructions on turning fragility curves into HCLPFs and Table of Seismic Boolean equations used by BNL and EQE to develop estimates of HCLPF for advanced BWR.

Fiche: 61463:071-61463:073

acn: $\quad 9204270119$

P.W. Marriott, GE, letter forwarding Section 4 inadvertently omitted from April 6, 1992, letter forwarding, "Tier 1 Design Certification Material for the GE Advanced BWR Design Stage 2 Submittal." Section 4 covers interface Tier 1 material in reference to ultimate heat sink.

Fiche: 61331:057-61331:060

acn: $\quad 9204130208$ 
April 8, 1992

April 8, 1992

April 8, 1992

April 9, 1992

April 9, 1992

April 10, 1992

April 10, 1992

April 11, 1992

April 14, 1992
P.W. Marriott, GE, letter forwarding 34--11 $\times 17$ foldout drawings identified for later delivery in March 13, 1992, submittal of Amendment 20 to advanced BWR SSAR. Updated page change instructions and page status sheets also enclosed. Enclosures withhold.

Ficho: 61506:354-61506:354

acn: $\quad 9204220093$

Text-eafety report--Amendment 20 to advanced BWR SSAR $11 \times 17$ foldout drawings page change instructions and page status shoots.

Ficho: 61396:245-61397:148

acn: $\quad 9204160195$

P.W. Marriott, GE, letter forwarding $11 \times 17$ drawings as part of Amendment 20 to GE advanced BWR SSAR per March 13, 1992, submittal. Page change instructions and page status sheets also enclosed.

Ficho: 61396:244-61398:148

acn: $\quad 9204160184$

J. Fox, GE, letter forwarding comments on selected items from Table 1.8-22 experience information applicable to advanced BWR covering storage of low level radwastes at sites and clarification of surveillance requirements for diesel impurity tests.

Fiche: $\quad 61784: 250-617 @ 4: 257$

acn: $\quad 9205190285$

G. Kelly, letter discussing follow-up on open items from advanced BY PR PRA draft SER and MAR moeting in San Jose, California.

Fiche: 61463:074-61463:075

acn: $\quad 9204270126$

G. Kelly, letter forwarding initial concerns raised by ACRS regarding credit for RWCU and FW system in high pressure sequences in advanced BWR PRA and evaluation of LOCAs outside of containment.

Fiche: $\quad$ 61463:076-61463:129

acn: $\quad 9204270130$

R.L. Palla, letter forwarding listed responses from GE regarding advanced BWR for review under Task Order 2 of FIN 1-2412. Advises that second document contains propriotary information. Without enclosure.

Fiche: $\quad$ 61415:322-61415:322

acn: $\quad 9204220130$

J. Fox, GE, letter forwarding Human Factors Engineering ITAAC-DAC Action Plan Item (4).

Ficho: $\quad 61884: 246-61884: 256$

acn: $\quad 9205280226$

R.C. Mitchell, letter forwarding proprietary GE responses to resolution of selected issues regarding advanced BWR design SER Chapter 19 (SECY-91-309). Responses withheld.

Fiche: $\quad 61364: 273-61364: 273$

acn: $\quad 9204160229$ 


\section{Appendix C}

April 15, 1992

April 20, 1992

R.C. Mitchell, letter forwarding proprietary responses to resolution of SECY-91-309 Confirmatory Item 1 as related to advenced BWR draft SER Chapter 19. Responses withheld.

Fiche: $\quad 61360: 347-61360: 347$

ecn: $\quad 9204160279$

P.W. Marriott, GE, letter forwarding response to SECY-91-309, Confirmatory Item 17, and Outstanding Item 18 (partial) for resolution of selected issues related to advanced BWR draft SER Chapter 19.

Fiche: $\quad$ 61464:228-61464:228

ecn: $\quad 9204240162$

April 22, 1992

P.W. Marriott, GE, letter forwarding responses to discussion items of October-November 1991, GE/NRC performance and quality evaluation branch conference. Responses withheld.

Fiche: 61495:328-61495:328

acn: $\quad 9204280363$

April 24, 1992

R.C. Stim, letter forwarding response to outstanding issues 140 and 144 in references to revision of Appendix 15e - ATWS analysis of ABWR DSER SECY-91-355.

Fiche: $\quad$ 61549:181-61549:305

acn: $\quad 9205010292$

April 24, 1992

P.W. Marriott, GE, letter forwarding proprietary revision to Appendix $19 \mathrm{f}$ and $19 \mathrm{e}$ for containment ultimate strength and 100-percent metal-water reaction. Appendix 9e revised to formally document increased pressure capability resulting from thicker drywell head. Enclosure withheld.

Fiche: $\quad$ 61509:320-61509:320

acn: $\quad 9204300361$

April 24, 1992

P.W. Marriott, GE, letter forwarding Section 2.15.10 Reactor Building of Stage 2 GE advanced BWR Tier 1 design certification material. Submittal supplement Tier 1 advanced BWR design certification material transmitted earlier by April 6, 1992, letter. Fiche: $\quad$ 61505:145-61505:188

acn: $\quad 9204290217$

April 27, 1992

P.D. Knecht, letter forwarding April 27, 1992, memorandum to BNL regarding LOCA outside containment in advanced BWRS.

Fiche: $\quad$ 61784:224-61784:229

acn: $\quad 9205200162$

April 28, 1992

C. Poslusny, NRC, meeting summary of March 25 and 26, 1992, with GE in San Jose, California regarding status of open issues design interfaces and ITAAC in reference to NRC review of SSAR for ABWR. Draft interim human factors criteria and GE proprietary information enclosed. GE proprietary information withheld.

Fiche: 61713:001-61713:161

acn: $\quad 9205140241$

April 28, 1992

J. Fox, GE, letter forwarding proposed draft advanced BWR TS Section 3.3.1.1-2 tegarding RPS instrukentation-logic.

Fiche: $\quad 61784: 258-61784: 275$

acn: $\quad 9205200188$ 
April 29, 1992

April 29, 1992

April 30, 1992

April 30, 1992

April 30, 1992

May 1, 1992

May 1, 1992

May 1, 1992

May 1, 1992

May 1, 1992
J. Fox, GE, letter forwarding nonproprietary and proprietary information on Section 3.11 and appendix of advanced BWR SSAR regarding environmental qualification of safety-related mechanical and electrical equipment. Enclosure withheld.

Fiche: 61815:001-61875:005

acn: $\quad 9205100241$

J. Fox, GE, letter forwarding information regarding reactor water makeup system, makeup water preparation system components, and HECWS system component description as beckground information for advanced BWR review.

Fiche: $\quad 61784: 171-61784: 205$

acn: $\quad 9205200192$

R.C. Stim, letter forwarding response to Agenda Itom 11 discussed during GE/NRC Reactor Systems Branch November 20 and 21, 1991, meeting regarding credit for nonsafety-grade equipment.

Fiche: $\quad 61589: 346-61589: 348$

acn: $\quad 9205050247$

Record of telecon with GE on April 30, 1992, regarding development of Advanced BWR Inventory SSAR Appendix 18f.

Fiche: $\quad$ 61878:337-61878:339

acn: $\quad 9205280186$

R.C. Stirn, letter forwarding Section 3.7, "Radiation Protection of Stage 2 GE Advanced BWR Tier I Design Certification Material," containing figures designating radiation zones for reactor building, control building, and radwaste building.

Fiche: $\quad$ 61605:232-61605:267

acn: $\quad 9205050240$

J. Fox, GE, letter forwarding proprietary information regarding advanced BWR fuel design. Enclosure withheld.

Fiche: 61815:007-61815:008

acn: $\quad 9105100218$

J. Fox, GE, letter forwarding proprietary information regarding intersystem LOCA.

Enclosure withheld.

Fiche: $\quad$ 61875:006-61815:006

acn: $\quad 9105100111$

G.E. Miller, letter forwarding draft of flooding analysis for potential piping leaks in reactor service water system.

Fiche: $\quad$ 61791:079-61791:082

acn: $\quad 9205190287$

G.E. Miller, letter forwarding information regarding advanced BWR HECW system to replace information sent on April 29, 1992.

Fiche: $\quad$ 61784:168-61784:170

acn: $\quad 9205200182$

J. Fox, GE, letter forwarding information regarding BWR containment steam bypass leakage capability. Sensitivity study results demonstrate that currently specified bypass leakage capability of $0.05 \mathrm{ft}^{2}$ is not at high point of cliff.

Fiche: 61784:206-61784:215

acn: $\quad 9205200150$ 
May 3, 1992

May 4, 1992

May 5, 1992

May 10, 1992

May 11, 1992

May 11, 1992

May 13, 1992

May 14, 1992

May 15, 1992

May 15, 1992

May 18, 1992
J. Fox, GE, letter forwarding comments on human factors engineering ITAAC-DAC. Ficho: $\quad$ 61814:294-61814:362

acn: $\quad 9205280188$

C. Poslusny, NRC, letter requesting that licensoe address enclosed questions regarding review of advanced BWR inservice testing.

Fiche: 61741:341-61741:352

acn: $\quad 9205200060$

J. Duncon, letter forwarding advanced BWR PRA punchout list.

Fiche: 61911:089-61911:111

acn: $\quad 9205290049$

C. Poslusny, NRC, summary of February 10 through 12, 1992, audit at GE San Jose, California office to review documentation and bases for establishment of ITAAC for ABWR RPV internals.

Fiche: $\quad$ 61785:034-61785:050

acn: $\quad 9205260196$

U. Saxena, letter forwarding viewgraphs of blowdown mass energy data used in advanced BWR subcompartment pressurization analyses.

Fiche: 61784:230-61784:249

acn: $\quad 9205190281$

D. Maxwell, letter forwarding response to NRC questions on Generic Letter 80-35 regarding de power supplies.

Fiche: 61791:075-61791:078

acn: $\quad 9205190280$

J. Fox, GE, letter forwarding table of Chapter 14 open items including test procedures, pre-fuel load checks, preoperational test procedures and interfaces.

Fiche: 61791:041-61791:069

acn: $\quad 9205190282$

J. Fox, GE, letter forwarding writeup of loose parts monitoring system which will appear in SSAR via upcoming amendment.

Fiche: $\quad 61784: 216-61784: 223$

acn: $\quad 9205200161$

R.C. Pierson, NRC, letter forwarding summary of advanced BWR Structural Design audit at $\mathbf{G E}$.

Fiche: $\quad 61794: 241-61794: 263$

acn: $\quad 9205280255$

R.C. Pierson, NRC, letter forwarding information and summarizes GE advanced BWR design process assessment.

Fiche: $\quad 61794: 229-61794: 240$

acn: $\quad 9205280244$

C.B. Brinkman, letter responding to issue of diversity for digital instrumentation and control system for System 80 delineated in NRC April 30, 1992, letter. Best estimate analysis underway in order to make realistic assessment of plant performance given computer failure.

Fiche: $\quad 61884: 189-61884: 193$

acn: $\quad 9205280060$ 
May 20, 1992

May 26, 1992.

May 28, 1992

May 28, 1992

May 28, 1992

May 29, 1992

May 29, 1992

May 29, 1992

May 29, 1992

May 30, 1992
R.C. Pienson, NRC, letter forwarding March 23 through 26, 1992, audit report of GB advanced BWR piping design and ITAAC. Audit agenda and list of attendees enclosed. Ficho: $\quad$ 61822:154-61822:212

scn: $\quad 9206010261$

D. Crutchfield, NRC, letter requeeting that vendor reconsider submittal on USIs and GSIs. Revised aubmittal should bo provided by June 30, 1992, to moet listed criteria. Ficho: 61822:050-61822:056 acn: $\quad 9206010145$

Text-enfety report, "Request for Additional Information Performance of Containment Structures Advanced BWR."

Fiche: $\quad$ 61822:284-61822:286

acn: $\quad 9205280183$

C. Poslusny, NRC, letter notification of June 8, 1992, meeting with GE in San Jose, California to discuss isoues regarding staff reviow of ABWR.

Ficho: 61883:331-61883:335

acn: $\quad 9206030321$

J.M. Taylor, NRC, text-safety report informs Commission of status of development of design acceptance criteria (DAC) for ABWR.

Fiche: $\quad$ 61979:005-61980:186

acn: $\quad 9206040228$

D. Crutchfield, NRC, letter forwarding announcement and invitation for Fourth Annual NRC Regulatory Information Conference on July 21 and 22, 1992, with GE to discuss status of ABWR and SBWR licensing effort since November 1991, ALWR conference. Fiche: $\quad$ 61883:266-61883:270 acn: $\quad 9206030340$

R.C. Pierson, NRC, letter advising that vendor must meet or exceed commitment dates for submittals required to complete evaluation of SSAR for GE advanced BWR.

Requests firm submittal date for necessary changes by June 3, 1992.

Fiche: $\quad 61920: 318-61920: 320$

acn: $\quad 9206020311$

J. Duncon, letter forwarding updated advanced BWR PRA punch-list reflecting results of March 23, 25, and 25, 1992, discussions.

Fiche: 61912:206-61912:227

acn: $\quad 9205290002$

D. Crutchfield, NRC, letter forwarding announcement and invitation for Fourth Annual NRC Regulatory Information Conference to discuss status of CE System 80 licensing effort since November 1991, ALWR conference.

Fiche: $\quad$ 61882:197-61882:201

acn: $\quad 9206030360$

P.W. Marriott, GE, letter forwarding, "Tier I Design Certification Material for GE ABWR Design," Stage 3 including design descriptions and proposed ITAAC for all ABWR systems for which design certification being sought.

Fiche: 61925:001-61926:308

acn: $\quad 9206020300$ 
Appendix C

June 1, 1992

General external technical reports, "Tier I Design Certification Material for GE ABWR Design."

Fiche: $\quad 61925: 003-61926: 308$

acn: $\quad 9206020303$

June 1, 1992

H.A. Careway, GE, letter forwarding modification to uppder drywell shielding and figure showing radiation field prior to additional shielding.

Fiche: $\quad$ 62152:009-52152:012

acn: $\quad 9206260036$

June 1, 1992

J. Fox, GE, letter forwarding additional changes to Chapter 14 of ABWR SSAR, in response to various telecons regarding closeout of open items from staff draft SER. Changes necessary to close Chapter 14 draft SER open items complete, except for Items 118,120 , and 121 .

Fiche: $\quad$ 62158:329-62158:356

acn: $\quad 9206260178$

June 1, 1992

June 1, 1992

J. Duncan, GE, letter forwarding sensitivity analysis of human error probabilities in advanced BWR PRA.

Fiche: $\quad$ 62199:301-62199:311

acn: $\quad 9206260275$

J. Fox, GE, letter forwarding nonproprietary and proprietary information regarding equipment qualification, in response to June 1, 1992, telecon and May 5 and 6, 1992, meeting. Proprietary information withheld.

Fiche: $\quad$ 62163:209-62163:210

acn: $\quad 9206290019$

June 1, 1992

June 1, 1992

J. Fox, GE, letter forwarding resonse to Questions 8 and 9 regarding ABWR drywell head buckling capability. Responses to other 11 questions will be provided soon.

Fiche: $\quad$ 62192:288-62912:294

acn: $\quad 9206290278$

J. Fox, GE, letter forwarding nonproprietary and proprietary information regarding containment hydrodynamic loads. Proprietary information withheld.

Fiche: $\quad$ 62230:249-62230:257

acn: $\quad 9207010268$

June 3, 1992

S.Q. Ninh, NRC, meeting summary of May 20, 1992, public meeting between NRC and ABB-CE in Rockville, Maryland to discuss staff comments on applicant pilot ITAAC submittal. Comments and list of attendees enclosed.

Fiche: $\quad$ 62036:001-62036:019

acn: $\quad 9206160251$

June 3, 1992

Legal transcripts and orders and pleadings; transcript of June 3, 1992, public meeting in Rockville, Maryland regarding status of GE advanced BWR application for design certification. With scheduling notes and viewgraphs.

Fiche: 61971:047-61971:133

acn: $\quad 9206100205$

June 3, 1992

L.G. Frederick, GE, letter forwarding Table 2, "Human Actions Below Top 300 Cutsets" and Teble 4, "Human Action Acronyms Deleted from Model," in response to NRC request for sensitivity analysis on human errors.

Fiche: 62153:358-62153:360

acn: 9206250301 
June 3, 1992

June 4, 1992

June 4, 1992

June 4, 1992

June 4, 1992

June 4, 1992

June 5, 1992

June 5, 1992

June 5, 1992

June 5, 1992
J. Fox, OE, letter forwarding information regarding HVAC exhaust monitoring.

Fiche: 62145:011-62145:013

acn: $\quad 9206260033$

R.C. Berglund, letter responding to NRC May 29, 1992, letter raising concerns that Stage 2 ITAAC submittal contained several inconsistencies reflected in lack of internal QA. Urges continuation of faco-to-face staff and management interactions.

Ficho: 61958:354-61958:356

acn: $\quad 9206080103$

C. Poslusny, NRC, meeting summaries-internal (non-transcript) summary of May 7, 1992, moeting with GE in Bethesda, Maryland regarding staff review of SSAR for advanced BWR.

Fiche: $\quad$ 62020:201-62020:315

acn: $\quad 9206120218$

J. Fox, GE, letter forwarding fax regarding response to Question 3 of ACRS letter and exemption requests from GDC 56.

Fiche: $\quad$ 62159:056-62159:085

acn: $\quad 9207060200$

J. Fox, GE, letter forwarding proprietary fax regarding response to PRA portion of Question 10 of April 13, 1992, letter pertaining to RWCU. Response withheld.

Fiche: 62251:060-62251:060

acn: $\quad 9207060110$

J. Fox, GE, letter forwarding material discussed on June 3, 1992, regarding ABWR suppression pool bypass. Material withheld.

Fiche: $\quad 62249: 360-62249: 360$

acn: $\quad 9207060159$

J.N. Fox, letter notifying that licensee now designated as, 'GE Nuclear Energy,' and abbreviated, 'GE.'

Fiche: 61995:357-61995:358

acn: $\quad 9206110279$

S.J. Stark letter responding to May 29, 1992, letter expressing concern regarding impact of $A B W R$ review by five day delay in providing information concerning tornado design features and submittal date for changes. Suggest issue be discussed at GE management meeting on June 8, 1992.

Fiche: 61997:260-61997:261

acn: $\quad 9206110168$

J. Fox, GE, letter forwarding intersystem LOCA evaluation.

'Fiche: 62160:280-62160:310

acn: $\quad 9206250344$

J. Fox, GE, letter forwarding intersystem LOCA evaluation, including proprietary pages 19B.2-44 and 19B.2-45 to ABWR SSAR. Proprietary pages withheld.

Fiche: 62273:001-62273:029

acn: $\quad 9206250344$ 
June 5, 1992

Juno 5, 1992

Juno 7, 1992

June 8, 1992

June 9, 1992

June 9, 1992

June 10, 1992

June 11, 1992

June 15, 1992

June 16, 1992
J. Duncan, GE, letter forwarding corrections to June 1, 1992, fax regarding human factorn, consiating of Table 2 regarding human actions below top 300 cutsets and Table 4 regarding humen sction acronyms deloted from model.

Ficho: 62250:097-62250:099

acn: $\quad 9207060143$

J. Duncan, GE, letter forwarding viewgraphs regarding status of koy PRA activities and backend analyees and severo accident cloeure, in preparation for June 8, 1992, meoting.

Fiche: 62250:087-62250:096

acn: $\quad 9207060154$

C. Buchholz, GE, lottor forwarding proprietary fax rogarding advanced BWR sensitivity and scoping atudies. Enclosuro withhold.

Fiche: 62251:059-62251:059

scn: $\quad 9207060120$

S.Q. Ninh, NRC, meeting summaries-internal (nontranscript) summary of March 6, 1992, moeting with GE in Rockville, Maryland regarding advanced BWR Open Issues regarding Human Factors Engineoring inspections, tests, analyses, and acceptance criteria and design acceptance criteria. Fiche: 62020:178-62020:184 acn: $\quad 9206120199$

J. Fox, GE, letter forwarding fax message regarding T\&C TS for primary containment isolation instrumentation.

Fiche: $\quad 62160: 007-62160: 030$

acn: $\quad 9206260206$

J. Fox, GE, letter forwarding responses to NRC audit of GE on ABWR piping design criteria and sample analysis on March 23 through 27, 1992, and Revision 2 to Design Bases Spec 386HA931, "Event Combinations \& Acceptance Criteria."

Fiche: $\quad 62190: 182-62190: 300$

acn: $\quad 9206260247$

U. Saxena, GE, letter forwarding information regarding wetwell-to-reactor building negative differential pressure.

Fiche: $\quad 62157: 341-62157: 345$

acn: $\quad 9206260280$

H.A. Careway, GE, letter forwarding proprietary drawing of Kashiwazaki Kariwa Nuclear Power Generation Station Units 5 and 7 shield wall penetrations, in reference to upper drywell access hatches. Drawing withheld.

Fiche: 62157:253-62157:253

acn: $\quad 9206260212$

J. Chambers, GE, letter forwarding discussion of major issues in advanced BWR TS that need resolution quickly in order to keep review on schedule.

Fiche: $\quad 62157: 338-62157: 340$

acn: $\quad 9206260278$

S.J. Stark, GE, letter forwarding information regarding GE overall design process to complete and control US advanced BWR final design.

Fiche: $\quad$ 62110:282-62110:285

acn: $\quad 9206240021$ 
June 16, 1992

June 17, 1992

June 17, 1992

June 22, 1992

June 25, 1992

June 26, 1992

June 26, 1992

June 26, 1992

June 27, 1992
J. Fox, GE, letter forwarding summary description of computer codes used in safety analyais, including ODYNA/REDYA modols for advanced BWR transient analysis.

Fiche: $\quad$ 62154:328-62154:333

acn: $\quad 9206250342$

S.J. Stark, OE, lotter forwarding additional Stage 3 Tier 1 design cortification matorial for OB ABWR design to aupplement and replece material transmitted by May 30, 1992, lettor.

Ficho: $\quad 62161: 001-62161: 112$

acn: $\quad 9206250321$

S.Q. Ninh, NRC, lettor providing summary of 18 confirmatory itoms identified in final SER for Chapter 18, Human Factors Engineering, where staff and GE have reached tentative agreoment.

Fiche: $\quad 62120: 202-62120: 214$

acn: $\quad 9206250409$

S.J. Stark, GE, letter forwarding advanced BWR SSAR, Section 18E.2, "Man-Machine Interface System" to support Design Acceptance Criteria 36. BNL will be providing information as dosignated in Tablo 18E.1.1.

Fiche: $\quad$ 62144:330-62144:357

acn: $\quad 9206290060$

J. Duncan, GE, letter forwarding new PRA Section 19.7 regarding PRA as design tool, updating April 7, 1992, fax.

Fiche: 62567:203-62567:212

acn: $\quad 9207290092$

J.N. Fox, GE, letter forwarding markup of NBS P\&ID, markup of Table 3.2-1, pages 3.2-12.4 and 3.2-9 and Section 3 of NN Newmark paper regarding earthquake-resistant design G. Ehlert discussed. W/one oversize drawing.

Fiche: 62199:312-62199:345

acn: $\quad 9206260207$

S,J. Stark, GE, letter discussing impact of changes in errors in ECCS evaluation methodology used by GE. Peak cladding temperature variations resulting from plantspecific system or fuel changes not addressed.

Fiche: $\quad 62227: 213-62227: 214$

acn: $\quad 9206300260$

T. Boyce, NRC, letter forwarding recommended addition to GE advanced BWR Tier 1 design descriptions and ITAAC and input to advanced BWR Tier 1 design documentation to incorporate radiation protection design acceptance criteria.

Fiche: $\quad$ 62152:028-62152:036

acn: $\quad 9206260054$

J. Fox, GE, letter forwarding proprietary fax regarding containment ultimate strength evaluation. Enclosure withheld.

Fichs: 62611:342-62611:344

ac's: $\quad 9207300174$ 
June 27, 1992

June 29, 1992

June 29, 1992

June 29, 1992

June 30, 1992

June 30, 1992

June 30, 1992

June 30, 1992

July 2, 1992

July 2, 1992
J. Duncan, GE, letter forwarding discussion of draft SER Open Itom 21 regarding design and reliability asoumptions and insights related to systom outside advanced BWR design cortification.

Fiche: 62567:173-62567:179

acn: $\quad 9207290083$

J. Duncan, GE, letter forwarding now Sections 19.11 through 19.13 of advanced BWR PRA regarding human action overview, PRA input to reliability assurance problem and summary of insights gained from PRA.

Fiche: 62567:165-62567:172

acn: $\quad 9207290080$

J. Duncan, GE, letter forwarding information on modification to advanced BWR

Paragraph 2.2.2 regarding consequence analysis/sito acceptability.

Fiche: 62567:213-62567:214

acn: $\quad 9207290095$

S.Q. Ninh, NRC, letter forwarding summary of confirmatory and open items identified in final SER for Chapter 12, "Radiation Protection," and Chapter 14, "Initial Plant Test Programs," for information.

Fiche: 62204:182-62204:195

scn: $\quad 9207060060$

J. Duncan, GE, letter forwarding PRA input to ITAAC Section 19.8 regarding Tier 1 treatment of design features identified as important by PRA.

Fiche: 62567:180-62567:191

acn: $\quad 9207290085$

J. Duncan, GE, letter forwarding information on Section 19.9 regarding COL license information, including specific procedure for unisolated RWCU line break, confirmation of RWCU operation beyond design basis and event-specific procedures for severe external flooding.

Fiche: $\quad 62567: 192-62567: 202$

acn: $\quad 9207290089$

J. Duncan, GE, letter forwarding updated advanced BWR PRA consequence analysis, covering consequence analysis results and additional results.

Fiche: 62567:215-62567:222

acn: $\quad 9207290098$

R.C. Pierson, NRC, letter discussing GE Nuclear schedule for submittal of FSSAR for advanced BWR.

Fiche: $\quad$ 62241:347-62241:349

acn: $\quad 9207070258$

D.J. Robare, GE, letter forwarding proprietary responses to generic power uprate ACRS open items noted in NRC June 3, 1992, letter. Responses withheld.

Fiche: $\quad$ 62262:272-62262:276

acn: $\quad 9207070257$

J. Fox, GE, letter forwarding proprietary fax regarding advanced BWR SSAR information reassessment. Enclosure withheld.

Fiche: 62638:225-62638:225

acn: $\quad 9207300161$ 
July 6, 1992

July 6, 1992

July 8, 1992

July 9, 1992

July 10,1992

July 13,1992

July 13, 1992

July 14, 1992

July 15, 1992

July 15,1992
S.J. Stark, GE, letter forwarding proprietary details of information submitting corrections or additions to submittal of Amendment 21 to GE's ABWR SSAR.

Fiche: $\quad$ 63139:224-63139:229

acn: $\quad 9209160126$

S.J. Stark, GE, letter forwarding Amendment 21 to advanced BWR SSAR.

Fiche: $\quad$ 62332:001-62334:026

acn: $\quad 9207100137$

J. Fox, GE, letter forwarding proprietary fax regarding minimum effort on responding to May 26, 1992, letter of GSI and USI guide for NRC advanced LWR review. Enclosure withheld.

Fiche: 62638:221-62638:224

acn: $\quad 9207300151$

H.A. Careway, GE, letter forwarding tables containing bin sorting used to produce Table 1-1 in June 30, 1992, fax sent to NRC as part of PRA consequence analysis, backup evaluations. Latest evaluation corrects weather input data error noted in original calculations.

Fiche: $\quad 62567: 102-62567: 105$

acn: $\quad 9207290013$

J. Duncan, GE, letter forwarding updated advanced BWR punch list regarding tasks to wrapup PRA. Review requested.

Fiche: $\quad 62567: 317-62567: 348$

acn: $\quad 9207290035$

R.C. Mitchell, GE, letter forwarding proprietary Amendment 21 drawings to ABWR SSAR. Drawings withheld.

Fiche: $\quad$ 62416:355-62416:356

acn: $\quad 9207160123$

R.C. Mitchell, GE, letter forwarding nonproprietary drawings to GE ABWR SSAR, Amendment 21.

Fiche: $\quad 62464: 136-62464: 304$

acn: $\quad 9207200077$

J. Fox, GE, letter forwarding Item B to inservice test schedule, consisting of draft amendment to Table 3.9-8, "Inservice Testing, Safety-Related Pumps \& Valves."

Fiche: 62568:001-62568:033

acn: $\quad 9207290010$

J. Fox, GE, letter forwarding update to Direct Containment Heating Report. Updated report withheld.

Fiche: $\quad$ 63945:021-63945:022

acn: $\quad 9211180251$

C. Poslusny, NRC, letter forwarding summary of interim evaluation concerning licensee May 21, 1992, submittal regarding justification for turbine building static seismic analysis.

Fiche: $\quad 62445: 318-62445: 322$

acn: $\quad 9207220369$ 
July 15, 1992

July 16, 1992

July 16, 1992

July 20, 1992

July 22, 1992

July 23, 1992

July 24, 1992

July 27, 1992

July 29, 1992

July 30,1992
C. Poslusny, NRC, letter forwarding listed documents regarding final SER review of advanced BWR SSAR and design certification material, consisting of agenda for July 27, 1992, management meeting, preliminary list of final SER open and confirmatory items and evaluation of structural ITAAC.

Fiche: 62568:034-62568:109

acn: $\quad 9207290012$

S.Q. Ninh, NRC, letter forwarding summary of confirmatory and open items identified in final SER for Chapters 2, 4, 5, 11, and 15 of advanced BWR.

Fiche: $\quad$ 62442:347-62442:354

acn: $\quad 9207220401$

S.Q. Ninh, NRC, letter forwarding summary of confirmatory and open items identified in final SER for Chapter 19, probabilistic risk assessment of advanced BWR.

Fiche: $\quad$ 62479:077-62479:088

acn: $\quad 9207240187$

J.F. Klapproth, GE, letter forwarding proprietary material presented at June 26, 1992, meeting regarding rotated bundle evaluation. Enclosure withheld.

Fiche: 62636:356-62636:360

acn: $\quad 9207310136$

J. Fox, GE, letter forwarding information regarding July 22 deferred response letter to P.W. Marriott from C. Poslusny dated May 4, 1992, for advanced BWR IST review.

Fiche: $\quad$ 63037:295-63037:332

acn: $\quad 9209090254$

J.N. Fox, GE, letter forwarding proprietary Toshiba test data of 10 reactor internal pump (RIP) and 9 RIP operations. Data withheld.

Fiche: $\quad 63164: 189-63164: 190$

acn: $\quad 9209160281$

NRC, letter submitting comments regarding PGA of OBE issue in Chapters 2 and 3 of SSAR.

Fiche: $\quad 63005: 358-63005: 359$

acn: $\quad 9209040145$

S.Q. Ninh, letter discussing identification of two preliminary confirmatory items and eight confirmatory open items identified in final SER for Chapter 10 regarding steam power conversion.

Fiche: 62609:332-62609:343

acn: $\quad 9208040214$

C. Poslusny, letter forwarding two sets of preliminary staff comments on GE's ABWR Phase III design certification material.

Fiche: 63003:097-63003:203

acn: $\quad 9209040085$

J. Fox, GE, letter forwarding information regarding additonal P\&ID test connections for IST code pump and valve tests and current changes (marked) to IST Table 3.9-8 of July 22, 1992.

Fiche: $\quad 63040: 311-63041: 003$

acn: $\quad 9209090248$ 
July 31, 1992

August 3, 1992

August 6, 1992

August 7, 1992

August 7, 1992

August 7, 1992

August 10, 1992

August 10, 1992

August 12, 1992
W.T. Russell, NRC, letter forwarding SE regarding generic bouding analyses and equipment evaluations contained in topical report NEDC-31984P. GE commitment to establish standardized program fundamental to success of generic BWR power uprate program.

Fiche: 62748:191-62748:203

acn: $\quad 9208120007$

C. Czajkowski, BNL, letter forwarding TER input for Chapters 5, 6, and 9 of ABWR SSAR regarding RCS ESF and auxiliary systems, respectively. Concludes that information in subject chapters acceptable. Report sent in fulfillment of Task Assignment 7 of FIN L-1892.

Fiche: 71418:307-71418:334

acn: $\quad 92078130010$

J. Fox, GE, letter forwarding information on advanced BWR fuel storage and handling. Advises that proposed revision to Section 9.1 and that significant changes regarding Sections 9.1.2.1.3 and 9.1.2.1.4, recognizing fuel storage racks are purchase equipment. Fiche: $\quad 63035: 349-63035: 361$

acn: $\quad 9209090238$

P.W. Marriott, GE, letter forwarding Invoices XT0477-92 and XT0553-92 for review charges inadvertently sent to licensee. GE has not yet filed formal application for NRC review of simplified BWR.

Fiche: $\quad$ 62792:039-62792:049

acn: $\quad 9208130172$

J. Fox, GE, letter forwarding information regarding RPV surveillance - advanced BWR. Fiche: $\quad$ 63037:339-63037:342

acn: $\quad 920909036$

C.E. Buchholz, GE, letter forwarding details of conceptual design for corium shield. Sheild design to prevent flow of molten core debris into lower drywell sumps. Information also being provided to ACRS in preparation for August 19, 1992, meeting. Fiche: 63948:004-63948:015 acn: $\quad 9211180277$

G. Kelly, NRC, forwarding additional questions regarding GE ABWR PRA submittals made during June 1992.

Fiche: $\quad 71549: 259-71549: 262$

acn: $\quad 9211180446$

J.F. Quirk, GE, letter providing responses to technical issues identified in April 13, 1992, letter regarding review of draft SER on GE advanced BWR design.

Fiche: 63947:021-63947:190

acn: $\quad 9211180239$

R.C. Pierson, NRC, letter forwarding detailed comments on Tier 1 design certification material submittal for ABWR. Additional detail consistent with SSAR to enable final evaluation for FDA requested.

Fiche: $\quad 62840: 147-62841: 018$

acn: $\quad 9208200151$ 
Appendix C

August 13, 1992

August 13, 1992

August 17, 1992

August 18, 1992

August 19, 1992

August 26, 1992

August 31, 1992

September 2, 1992

September 4, 1992

G. DeGrassi, BNL, letter forwarding trip report of July 28 through 31, 1992, visit to San Jose, California, to complete review of GE proposed piping design criteria and sample analyses for ABWR.

Fiche: $\quad$ 71464:302-71464:348

acn: $\quad 9208280216$

R.C. Pierson, NRC, letter requesting review of enclosure, "ABWR Reactor Water Cleanup System Review," for proprietary information. Advises ACRS intent to discuss report at subcommittee meeting on August 19, 1992. Report withheld.

Fiche: $\quad 71420: 185-71420: 187$

acn: $\quad 9208190232$

R.C. Pierson, NRC, letter forwarding confirmatory and open items identified in FSER for Chapter 7 regarding instrumentation and control system of ABWR.

Fiche: $\quad 62864: 350-62864: 358$

acn: $\quad 9208240353$

R.C. Mitchell, GE, letter forwarding proprietary pages to SSAR for ABWR.

Fiche: $\quad$ 62922:279-62922:282

acn: $\quad 9208240159$

R.C. Pierson, NRC, letter forwarding August 18, 1992, memo from W.T. Russell to D.M. Crutchfield regarding proposed changes to 10 CFR Part 100, Appendix A, and draft evaluation concerning use of single earthquake design for advanced BWR.

Fiche: 62896:126-62896:138

acn: $\quad 9208260207$

J.F. Quirk, GE, letter forwarding GE evaluation of common mode failure of ditigal instrumentation and control, dated June 8, 1992. Evaluation identifies set of safetygrade control room displays and controls, independent of computer system to satisfy staff position.

Fiche: $\quad 63051: 291-63051: 337$

acn: $\quad 9209090221$

J. Fox, GE, letter forwarding page 5.3-4 of ABWR SSAR, Amendment 15 regarding RPV surveillance, reflecting weld specimen definition change, per B. Elliot suggestion.

Fiche: $\quad$ 63947:350-63947:353

acn: $\quad 9211180281$

R.C. Pierson, NRC, letter requesting that schedule be provided consistent with resolving identified concerns regarding SSAR Appendix 19P. "Evaluation of Potential Design Mods to ABWR," by middle of October 1992.

Fiche: $\quad$ 63129:065-63129:069

acn: $\quad 9209140221$

J.F. Klapproth, GE, letter submitting agenda items for GE fuel technology update meeting on September 22, 1992, in Rockville, Maryland. Items include GE 11 audit findings closure, stability update, new product development overview of GE 12 and 13 and upcoming license submittals.

Fiche: $\quad 63214: 332-63214: 332$

acn: $\quad 9209210040$ 
September 9, 1992

September 11, 1992

September 11, 1992

September 11, 1992

September 11, 1992

September 16, 1992

September 16, 1992

September 16, 1992

September 18, 1992

September 21, 1992
P.D. Knecht, GE, letter providing preliminary draft responses to NRC request for information regarding pool bypass, per August 18, 1992, fax.

Fiche: 63929:106-63929:114

acn: $\quad 9211180322$

J.N. Fox, GE, letter forwarding responses to Piping Design Audit Open Items A-10, A17 , and A-28.

Fiche: $\quad 63396: 217-63396: 232$

acn: $\quad 9210050222$

M. Ross, GE, letter forwarding update of HFE Tier 2 design acceptance criteria.

Fiche: $\quad$ 63960:023-63960:047

acn: $\quad 9211190025$

R.C. Pierson, NRC, letter requesting that GE provide staff with prioritized list of ABWR TS to be based on risk and reliability considerations, per July 27, 1992, ABWR open issues meeting.

Fiche: $\quad$ 63283:350-63283:354

acn: $\quad 9209240258$

R.C. Pierson, NRC, letter discussing guidance for use of single-earthquake design for systems, structures, and components in ABWR. Safety evaluation regarding use of single-earthquake design enclosed.

Fiche: $\quad$ 63283:271-63283:282

acn: $\quad 9209240282$

J. Fox, GE, letter forwarding presentation material from "Advanced Reactor Programs Advanced BWR Control Room Design," presented by M.A. Ross in Tokyo, Japan, on April 3 and 4, 1992.

Fiche: $\quad 63948: 074-63948: 143$

acn: $\quad 9211180320$

C. Poslusny, NRC, letter forwarding summary of open items resulting from NRC review of SSAR Sections 3.7 and 3.8 and NRC audits conducted at San Jose office. Two followup audits will be conducted at Bechtel office in San Francisco in October and November.

Fiche: $\quad 63200: 324-63200: 332$

acn: $\quad 9209180067$

R.C. Pierson, NRC, provides enclosed staff comments on Section 3.5, "Software Development," of Tier 1 design certification material for GE ABWR for review.

Requests set of revised ITAAC for section in timely manner. ITAAC will be discussed at next management meeting.

Fiche: 63321:011-63321:129

acn: $\quad 9209290248$

P.W. Marriott, GE! letter forwarding Amendment 22 to "ABWR SSAR."

Fiche: 63349:001-63354:237

acn: $\quad 9210010116$

' P.W. Marriott, GE, letter forwarding foldoout drawings of selected sections of Chapters $8,9,12,15$, and 18 of Amendment 22 to ABWR SSAR.

Fiche: $\quad 63380: 187-63380: 307$

acn: $\quad 9210010066$ 


\section{Appendix C}

September 22, 1992

September 24, 1992

September 30, 1992

September 30, 1992

October 1, 1992

October 2, 1992

October 5, 1992

October 6, 1992

October 8, 1992

October 8, 1992
C. Poslusny, NRC, letter forwarding draft staff preliminary evluation of ABWR design performance under severe conditions to be used as basis for discussions in September 29 through October 1, 1992, public meeting in Rockville.

Fiche: $\quad$ 71492:127-71492:194

acn: $\quad 9209280237$

C.E. Buchholz, GE, letter submitting clarification/additional information needed for closure of Lovel 2 PKA issues.

Fiche: $\quad 63948: 208-63948: 244$

acn: $\quad 9211180101$

J.F. Klapproth, GE, letter forwarding GE-NE-770-24-0892, "Generic Model for Probability of Operation w/Mis-Oriented Fuel Bundle, " per June 26, 1992, meeting with NRC regarding rotated bundle event licensing basis change.

Fiche: $\quad 63466: 220-63466: 235$

acn: $\quad 9210090175$

R.C. Pierson, NRC, letter providing clarification to September 2, 1992, request for additionui information regarding advanced BWR SSAR Appendix 19P.

Fiche: $\quad 63452: 350-63452: 351$

acn: $\quad 9210080267$

J. Duncan, GE, letter forwarding updated ABWR punch list for PRA, as discussed in September 22., 1992, meeting with NRC.

Fiche: $\quad 63942: 099-63942: 136$

acn: $\quad 9211180246$

J. Fox, GE, letter forwarding proposed modification to Subsection 3.5.1.1.1.4 regarding internal missiles - fans.

Fiche: $\quad$ 63948:280-63948:282

acn: $\quad 9211180086$

G. Kelly, NRC, letter forwarding list of questions regarding reliability assurance program, ABWR seismic margins analysis, RWCU and requantification of ABWR PRA. NRC working on better description of staff expectations regarding seismic margins analysis for ABWR PRA.

Fiche: $\quad$ 71550:016-71550:022

acn: $\quad 9211180457$

J. Fox, GE, letter forwarding information regarding ablation of inner steel plate and fill concrete.

Fiche: 63956:303-63956:307

acn: $\quad 9211180102$

G.W. Ehlert, GE, letter forwarding detailed pedestal structural drawing of ABWR.

Fiche: $\quad$ 63952:355-63952:360

acn: $\quad 9211180108$

J. Fox, GE, letter forwarding IST responses to telecon questions on October 6, 1992, for discussion on October 9, 1992.

Fiche: 63956:283-63956:292

acn: $\quad 9211180113$ 
October 8, 1992

October 9, 1992

October 9, 1992

October 12, 1992

October 14, 1992

October 16, 1992

October 20, 1992

October 27, 1992

October 29, 1992
J. Fox, GE, letter forwarding proposed resolution of ISLUCA for ABWR, including modified P\&ID for affected system. GE will prepare corresponding modification to Subsection 19B.2.15 regarding high/low pressure interface design following NRC review and approval of proposed ISLOCA.

Ficho: 63943:338-63943:350

acn: $\quad 9211180288$

A. McSherry, GE, letter forwarding proprietary Revision 1 to 23A1317, "Safety System Logic \& Control System Design Spec."

Fiche: 63939:326-63939:327

acn: $\quad 9211180128$

R.L. Nease, letter forwarding summary of each confirmatory and open item identified in draft FSER for GE ABWR, in support of upcoming meetings between GE and NRC to discuss closure of issues.

Fiche: 63519:001-63519:131

acn: $\quad 9210160301$

J. Fox, GE, letter forwarding changes to Table 3.9-8 regarding IST safety-related pumps and valves.

Fiche: 63948:325-63948:328

acn: $\quad 9211180119$

J.N. Fox, GE, letter forwarding modified responses to piping design audit Open Items A-6 and A-26, and calculational summary for SRV-quencher and pedestal weld stress analysis corresponding to Open Item A-4.

Fiche: $\quad 63942: 289-63942: 319$

acn: $\quad 9211180238$

J.N. Fox, GE, letter forwarding response to piping design audit Open Items A-12 and A-25 regarding combination of inertia and relative support motion effects and acceleration level for calculation of missing mass contributions, respectively. Calculation enclosed.

Fiche: 63942:190-63942:209

acn: $\quad 9211180230$

D.M. Crutchfield, NRC, letter forwarding draft final safety evaluation report on ABWR. Report contained significant number of open and confirmatory items which must be resolved prior to completion of final report.

Fiche: $\quad$ 63670:001-63672:185

acn: $\quad 9210270334$

J.Duncan, GE, letter forwarding reponse to questions regarding advanced BWR PRA.

Fiche: 71549:002-71549:009

acn: $\quad 9211180304$

R.C. Pierson, NRC, letter forwarding list of questions regarding NRC reliability study and evaluation of internal floods and fires during modes other than full power. Questions not to be regarded as request for new information.

Fiche: $\quad 63780: 250-63780: 255$

acn: $\quad 9211050341$ 


\section{Appendix C}

November 3, 1992

November 13, 1992

November 16, 1992

November 17, 1992

November 20, 1992

November 20, 1992

November 20, 1992

November 20, 1992

December 1, 1992

December 2, 1992
C.E. Buchholz, GE, letter submitting response to questions from September 29, 1992, meeting regarding type of concrete used in pedestal, mass of material used in core concrete interaction calculations, and time of $\mathrm{Zr}$ depletion for bounding sequence for core concrete interaction sequence.

Fiche: 63947:002-63947:020

acn: $\quad 9211180294$

J. Fox, GE, letter forwarding chart reflecting remaining ABWR certification process and ABWR FDA schedule.

Fiche: $\quad 63947: 249-63947: 252$

acn: $\quad 9211180299$

J.N. Fox, GE, letter forwarding preliminary, "Sample Analysis for Effect of Postulated Pipe Break - ABWR Main Steam Piping." Report provides sample pipe break analysis and addresses remaining SSAR issues raised during audit regarding postulated pipe ruptures.

Fiche: $\quad 63948: 144-63948: 207$

acn: $\quad 9211180338$

C. Poslusny, NRC, letter forwarding comments and questions from preliminary review of pilot TS for advanced BWR I\&C system.

Fiche: $\quad$ 63950:270-63950:273

acn: $\quad 9211200016$

' R.C. Mitchell, GE, letter forwarding modifications to Amendment 23 to ABWR SSAR. Mods includes partial resolution of COL license information, codes, and standards update, piping audit responses, expansion of inservice testing, 60-year vessel surveillance plan, and update of dose assessment.

Fiche: 64035:001 $164038: 126$

acn: $\quad 9211300015$

R.C. Mitchell, GE, letter forwarding proprietary modifications to Amendment 23 to ABWR SSAR.

Fiche: $\quad 64044: 176-64044: 176$

acn: $\quad 9211300021$

R.C. Mitch:oll, GE, letter forwarding changes to proprietary $11 \times 17$ foldout drawings from Chapter 7 of ABWR SSAR, Amendment 23.

Fiche: $\quad 64015: 316-64015: 316$

acn: $\quad 9211300034$

R.C. Mitchell, GE, letter forwarding changes to nonproprietary $11 \times 17$ foldout drawings from Chapter 8 of ABWR SSAR, Amendment 23.

Fiche: $\quad$ 64059:183-64059:206

acn: $\quad 9211300041$

G. Galletti, NRC, letter forwarding items identified as result of staff review of GE advanced BWR shutdown panel instrumentation inventory w/o enclosure.

Fiche: $\quad$ 63950:270-63950:273

acn: $\quad 9301150099$

C. Poslusny, NRC, letter forwarding SE accepting GE proposal for implementing ISLOCA issue resolution for advanced BWR.

Fiche: $\quad$ 64157:099-64157:107

acn: $\quad 9212070153$ 
December 8, 1992

December 8, 1992

December 10, 1992

December 15, 1992

December 21, 1992

December 21, 1992

December 22, 1992

December 23, 1992

December 28, 1992
R. Louison, GE, letter forwarding marked-up advanced BWR design document, Section 2.10.1, "Turbine Main Steam System," Section 2.10.2, "Condensate Feedwater \& Condensate Air Extraction System" and Section 2.10.4, "Condensate Purification System."

Fiche: $\quad 64270: 253-64270: 284$

acn: $\quad 9212170035$

R. Louison, GE, letter forwarding listed ABWR ITAAC sections and response to NRC questions and comments on system.

Fiche: $\quad$ 64281:001-64281:107

acn: $\quad 9212210192$

C.E. Buchholz, GE, letter responding to remaining currently open items raised regarding ABWR SSAR.

Fiche: $\quad 64807: 247-64807: 251$

acn: $\quad 9302100083$

C. Poslusny, NRC, letter forwarding preliminary evaluation of ABWR design for instrumentation \& control diversity per open item noted in NRC draft final SER. Most of items satisfactorily resolved. Expects discussion of diversity issue at January 21, 1993, management meeting.

Fiche: $\quad$ 64261:080-64261:093

acn: $\quad 9212180127$

C. Poslusny, NRC, letter forwarding preliminary safety evaluation for information provided by GE regarding capacity of reinforced concrete containment vessel in Appendix 19F of SSAR. Advises that additional information necessary.

Fiche: $\quad 64440: 328-64440: 339$

acn: $\quad 9301040056$

C. Poslusny, NRC, letter forwarding proposed scope of operating experience review regarding resolution of open item in draft final SER for human factors engineering design for advanced BWRs.

Fiche: $\quad$ 64602:197-64602:200

acn: $\quad 9301150311$

G. Kelly, NRC, letter forwarding list of clarifications needed to complete NRC review of LOCA outside containment for advanced BWR PRA.

Fiche: $\quad 64600: 349-64600: 350$

acn: $\quad 9301150320$

C. Poslusny, NRC, letter discussing status of GE advanced BWR shutdown risk draft FSER.

Fiche: $\quad 64432: 303-64432: 305$

acn: $\quad 9212310122$

G. Kelly, NRC, letter forwarding requested clarification that deals with areas of GE Chapter 19, Appendix K submittal (PRA input to reliability assurance program).

Fiche: $\quad$ 64572:027-64572:028

acn: $\quad 9301150086$ 
Appendix C

January 7, 1993

D.J. Robare, GE, letter forwarding selected section of Chapter 6, "BSF" of SSAR for advanced BWR, consisting of nonproprietary $11 \times 17$ foldout drawings of standby gas treatment system.

Fiche: $\quad 64554: 336-64554: 343$

acn: $\quad 9201130182$

January 7, 1993

D.J. Robare, GE, letter forwarding proprietary selected sections of Chapter 7, "Instrumentation and Control System of SSAR for Advanced BWR," consisting of Amendment $2411 \times 17$ foldout drawings to $\mathrm{OE}$.

Fiche: 64554:333-64554:333

acn: $\quad 9301130194$

January 7, 1993

January 12, 1993

D.J. Robare, GE, letter forwarding selected sections of Chapter 1, "Introduction and General Description of Plant," Chapter 3, "Design of Structures, Components and System," consisting of Amendment 24 to GE advanced BWR SSAR.

Fiche: $\quad$ 64555:001-64555:296

acn: $\quad 9301130218$

I. Fox, GE, letter forwarding list of recent submittals related to resolution of open items identified in draft final SER for ABWR.

Fiche: $\quad$ 64710:001-64712:035

acn: $\quad 9301270253$

January 12, 1993

January 13, 1993

G. Kelly, NRC, letter forwarding updated punch list for ABWR PRA issues. Overlap of issues assocaited with CA-1, CA-2 and CA-3, in that issues also covered in "belonging to other branches" eliminated.

Fiche: $\quad$ 74348:231-74348:241

acn: $\quad 9303220102$

J.N. Fox, GE, letter forwarding responses to questions transmitted via NRC December 23, 1992, letter on ABWR shutdown risk study (App 19Q).

Fiche: $\quad$ 64681:350-64681:354

acn: $\quad 9301260237$

January 14, 1993

P.P. Stancavage, GE, letter responding to NRC December 21, 1992, request for additional information regarding preliminary input to final SER on containment performance. Analysis of axisymmetric structures, taking into account nonlinear behavior, will be submitted by January 20, 1993.

Fiche: $\quad 64600: 360-64600: 361$

acn: $\quad 9301150233$

January 14, 1993

J. Fox, GE, letter forwarding resubmittal of responses to four NRC questions on most recent draft PRA input to RAP, Appendix 19K, and draft SSAR, Appendix 19K, with respect to ABWR review schedule. Responses originally submitted via facsimile on January 8, 1993.

Fiche: $\quad 64681: 355-64681: 358$

acn: $\quad 9301260230$

January 14, 1992

G. Kelly, NRC, letter forwarding further updated punch list for ABWR issues. Informs that NRC has not received submittal from GE on internal flooding (from hot high pressure fluids) subcompartment analysis.

Fiche: $\quad 74348: 189-74348: 200$

acn: $\quad 9303220069$ 
January 15,1993

January 18, 1993

January 19, 1993

January 20, 1993

January 22, 1993

January 25, 1993

January 25, 1993

January 25, 1993

January 25, 1993
J. Fox, GE, letter forwarding resubmittal of GE comments on NRC ABWR PRA issue status punch list, dated January 14, 1993. Comments originally submitted via facsimilo on January 14, 1993, with respect to accelerated ABWR review schedule.

Fiche: $\quad$ 64688:327-64688:339

acn: $\quad 9301260264$

J. Fox, GE, letter forwarding responses to December 22, 1992, memo regarding clarification on LOCAs outside of containment, with respect to accelerated ABWR reviow schedule.

Fiche: $\quad 64685: 272-64685: 303$

den: $\quad 9301260268$

J. Fox, GE, letter forwarding revised proposed closure of ABWR DFSER Open Item 17.3.5-1 in support of accelerated ABWR reviow schedule.

Fiche: $\quad$ 64699:263-64699:282

acn: $\quad 9301280210$

J. Fox, GE, letter forwarding Bechtel Rept RPRT-STRU-008, Revision O, "Containment Structrural Evaluation for Preasure Capacity Summary Report," in reference to GE plan for resolving Appendix 19F open items, dated January 14, 1993.

Fiche: $\quad$ 64699:283-64699:295

acn: $\quad 9301280204$

J. Fox, GE, letter forwarding ABWR SSAR markups addressing Open Items 6.2.1.6-1, 6.2 1.6-2, 6.2.4.1-1, 6.2.4.1-2, 6.2.4.1-3, and 6.5.1-2, and Confirmatory Items 6.5.1-2, including additional change in Subsection 6.2.1.2-2.

Fiche: $\quad 64700: 334-64700: 347$

acn: $\quad 9301280197$

J. Fox, GE, letter forwarding drafts of ABWR design document, MOV design description, and modified Subsection 3.9.6, IST of pumps and valves, in support of acelerated ABWR review schedule.

Fiche: $\quad$ 64761:347-64761:354

acn: $\quad 9302030256$

J. Fox, GE, letter forwarding ABWR SSAR markups of proprietary pages addressing Confirmatory Items 4.2-2 and 5.1-1, reflecting corrections or additions to earlier submittals and proprietary affidavits under which pages originally issued.

Fiche: 71618:087-71618:087

acn: $\quad 9302030264$

S.Q. Ninh, NRC, letter discussing preliminary staff evaluation of ABWR severe accident performance.

Fiche: $\quad 64697: 319-64697: 321$

acn: $\quad 9301280269$

S.Q. Ninh, NRC, letter advising of summary of open items listed in Section 1.6 of ABWR draft final SER. Changes listed.

Fiche: 71611:145-71611:154

acn: $\quad 9301280273$ 
Appendix C

January 26, 1993

January 28, 1993

January 28, 1993

January 28, 1993

January 29, 1993

January 29, 1993

January 29, 1993

January 29, 1993

January 29, 1993

January 29, 1993

S.Q. Ninh, NRC, letter discussing audit of ABWR structural design to be held February 22 through 25, 1993, regarding review of design calculations to close out open items identified in draft final safety ovaluation report.

Fiche: 64724:355-64724:357

acn: $\quad 9302010293$

J. Fox, GE, letter forwarding responses to NRC questions on RHR alarms and modification to SSAR Subsection 9.3.2.3.2 regarding feedwater corrosion product monitor per accelerated advanced BWR review schedule.

Fiche: $\quad 64760: 285-64760: 288$

acn: $\quad 9302030027$

J. Fox, GE, letter forwarding markups of advanced BWR SSAR Sections 3.6 and 3.9 for OBE elimination and elimination of AP \& SSE load combination to support accelerated advanced BWR review schedule.

Fiche: $\quad 64760: 257-64760: 270$

acn: $\quad 9302030040$

G. Kelly, NRC, letter forwarding questions previously sent (by fax or letter) regarding ABWR PRA, as discussed in San Jose, January 1993, management meeting. Thoughts on PRA-based ITAAC also enclosed.

Fiche: 74348:207-74348:229

acn: $\quad 9303220092$

P.W. Marriott, GE, letter forwarding Amendment 25 to GE advanced BWR SSAR, Chapter 13, conduct of operations.

Fiche: $\quad$ 64706:281-64706:281

acn: $\quad 9301290129$

P.W. Marriott, GE, letter forwarding Amendment 25 to "ABWR SSAR."

Fiche: $\quad$ 64764:117-64764:234

acn: $\quad 9302030035$

J. Fox, GE, letter forwarding draft of Section 19E.2, deterministic analyses of plant performance for "ABWR SSAR," Chapter 19, in support of accelerated ABWR review schedule.

Fiche: 64770:092-64771:071

acn: $\quad 9302030293$

J. Fox, GE, letter forwarding draft responses to advanced BWR SSAR Chapter 8 nonITAAC draft FSER items. Listed items will be addressed by February 8, 1993.

Fiche: $\quad$ 64771:181-64771:268

acn: $\quad 9302030307$

P.W. Marriott, GE, letter forwarding nonproprietary $11 \times 17$ foldout drawings to Amendment 25 to "ABWR SSAR."

Fiche: $\quad$ 64762:317-64762:347

acn: $\quad 9302030355$

P.W. Marriott, GE, letter forwarding proprietary pages $4 C-1$ and $4 C-1.1$ to Amendment 25 to "ABWR SSAR."

. Fiche: 64760:236-64760:236

acn: $\quad 9302030380$ 
January 29, 1993

January 29, 1993

January 30, 1993

February 1, 1993

February 2, 1993

February 2, 1993

February 2, 1993

February 3, 1993

February 4, 1993

February 9, 1993
J. Fox, GE, tetter forwarding proposal to characterize man-made site design parameters regarding missiles and gases, in support of accelerated ABWR review schedule.

Fiche: 64809:186-(14809:189

acn: $\quad 9302100150$

J. Fox, GE, letter forwarding response to request for additional information on ABWR podestal anchorage.

Fiche: $\quad 64808: 351-64808: 352$

acn: $\quad 9302100225$

J. Fox, GE, letter forwarding markups of proposed changes to Chapters 2 and 3 open issue resolution and Appendix 3H, supporting accelerated advanced BWR review schedule.

Fiche: $\quad 64765: 001-64766: 040$

acn: $\quad 9302030262$

J. Fox, GE, letter forwarding markup of ABWR SSAR Chapter 16 in accordance with STS (NUREG-1433 and NUREG-1434).

Fiche: 64803:066-64804:297

acn: $\quad 9302100456$

J. Fox, GE, letter forwarding "Submittal Supporting Accelerated ABWR Review Schedule."

Fiche: $\quad 64777: 296-64777: 303$

acn: $\quad 9302040095$

J. Fox, GE, letter forwarding first five pages of C. Buchholz December 10, 1992, fax containing response to currently open items, in support of accelerated ABWR review schedule. Last 19 pages successfully transmitted on December 10, 1992.

Fiche: $\quad 64807: 246-64807: 251$

acn: $\quad 9302100076$

C. Poslusny, NRC, letter forwarding preliminary revision of DFSER pages 4-2 through 4-4 for information and to facilitate further discussions of resolution of outstanding items for Chapter 4.

Fiche: $\quad 64788: 317-64788: 324$

acn: $\quad 9302110345$

J. Fox, GE, letter forwarding markup of Section 2.3 regarding COL information, addressing all draft FSER Chapter 2 COL action items to support accelerated ABWR schedule.

Fiche: $\quad 64828: 314-64828: 322$

acn: $\quad 9302110362$

J. Fox, GE, letter forwarding comparison of SSAR and industry initiatives on piping design and analyses to support accelerated ABWR review schedule.

Fiche: $\quad 64851: 271-64851: 275$

acn: $\quad 9302110358$

J. Fox, GE, letter forwarding submittal supporting accelerated advanced BWR review schedule. Submittal for resolution of open and confirmatory piping DFSER items listed in Attachment 1, including previously closed items for information.

Fiche: $\quad$ 64834:077-64834:170

acn: $\quad 9302160193$ 
Appendix C

February 9, 1993

February 9, 1993

February 10, 1993

February 11, 1993

February 12, 1993

February 12, 1993

February 12, 1993

February 12, 1993

February 16, 1993

J. Fox, GE, letter forwarding complete set of draft responses to advanced BWR SSAR, Chapter 8 non-ITAAC draft FSER open itoms, including Open Item 8.3.5-1 regarding roadmap. Transmittal replaces January 29, 1993, transmittal, and incorporatee information diecussed in telecons.

Fiche: $\quad$ 64854:194-64854:302

acn: $\quad 9302170004$

J. Fox, GE, letter forwarding responses to open issues documented in Sections 2.1 and 2.3 of Enclosure 2 to NRC November 13, 1992, summary of October 12 through 15, 1993, meeting, to support accelerated advanced BWR review schedule.

Fiche: $\quad 64854: 001-64854: 125$

acn: $\quad 9302170007$

J. Fox, GE, letter forwarding proposed replacement of ABWR Appendix 3A, "Seismic Soil-Structure Interaction Analysis Report," as followup to January 30, 1993, transmittal supporting accelerated ABWR review schedule.

Fiche: 64845:001-64845:348

acn: $\quad 9302170090$

T.H. Boyce, NRC, letter forwarding summary of January 11 through 27, 1993, meeting with licenseo regarding ITAAC.

Fiche: $\quad$ 64915:147-64915:302

a in: $\quad 9302230271$

J. Fox, GE, letter forwarding proposed changes to Section 3.2 of Revision $A$ to

23A6100AE, addressing issue of main steam line leakage path and seismic classification.

Fiche: 64957:269-64957:282

acn: $\quad 9302220094$

J. Fox, GE, letter forwarding proprietary markups of Sections 11.2, 11.3, and 11.4 addressing Open Items 20.2-2 and COL Action Items 9.3.8-2, 11.0-1, 11.2.1-1, 11.2.1.2, 11.2.2-1, 11.2.2-3, 11.3.2-1, 11.4.1-1, 11.4.1-2, 11.4.1-3 and 11.4.2-1. Withheld.

Fiche: $\quad$ 98472:013-98472:025

acn: $\quad 9302240247$

J. Fox, GE, letter forwarding markup of advanced BWR SSAR Section 14.2 regarding preoperational testing, addressing Open Items 14.2.12.3-1 and 14.2.12.3-2, to support accelerated advanced BWR review.

Fiche: 74133:002-74133:214

acn: $\quad 9303040061$

C. Poslusny, NRC, letter forwarding guidance documents regarding Tier 2 information considered in preparation of SSAR revisions to complement ITAAC items discussed in recent meetings with MEM staff.

Fiche: $\quad 64846: 357-64846: 361$

acn: $\quad 9302160142$

J. Fox, GE, letter forwarding proposed draft as severe accident input into Tier 2. Only few items suitable for inclusion in ITAAC. Cross-tie for firewater system and containment overpressure protection system should be identified in ITAAC.

Fiche: $64966: 355-64966: 361$

acn: $\quad 9302190359$ 

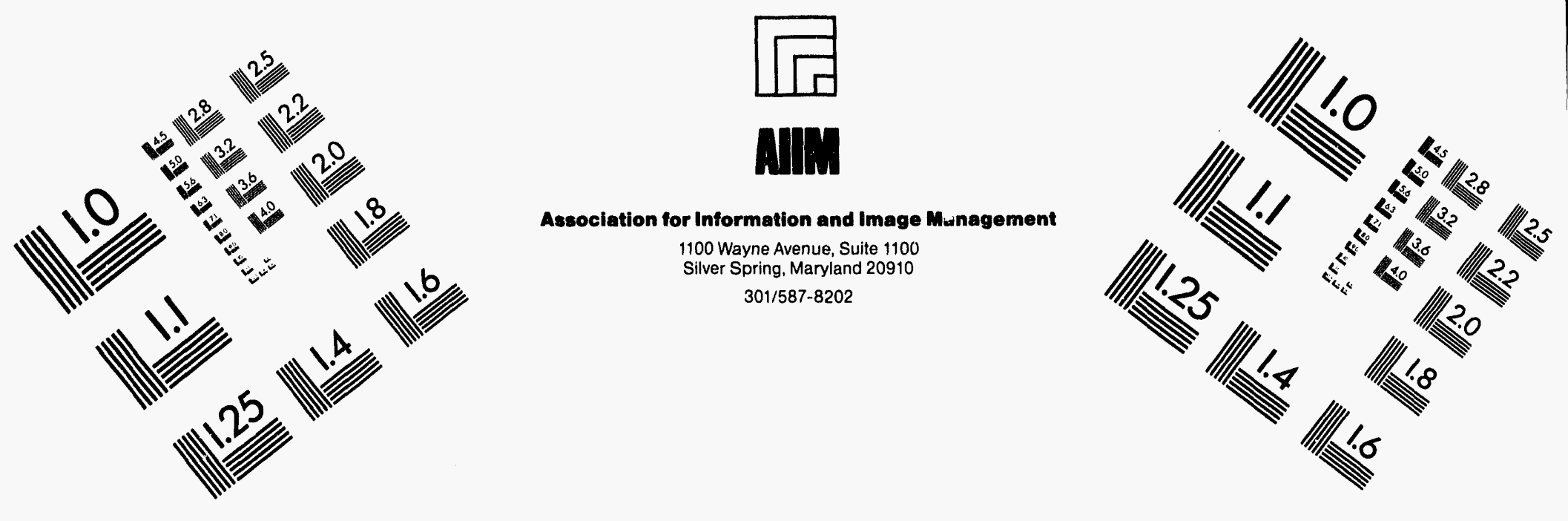

\section{Centimeter}

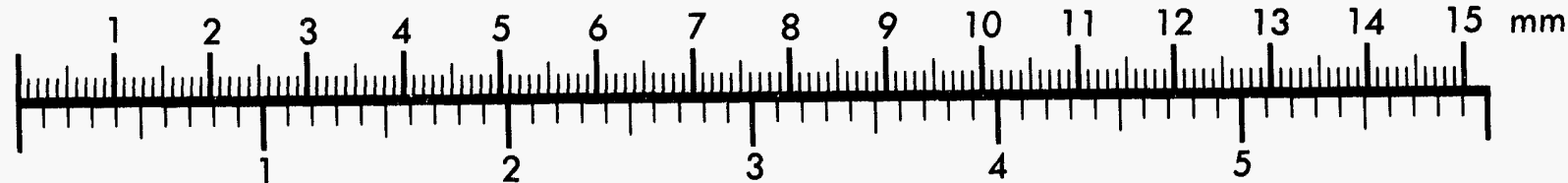
Inches
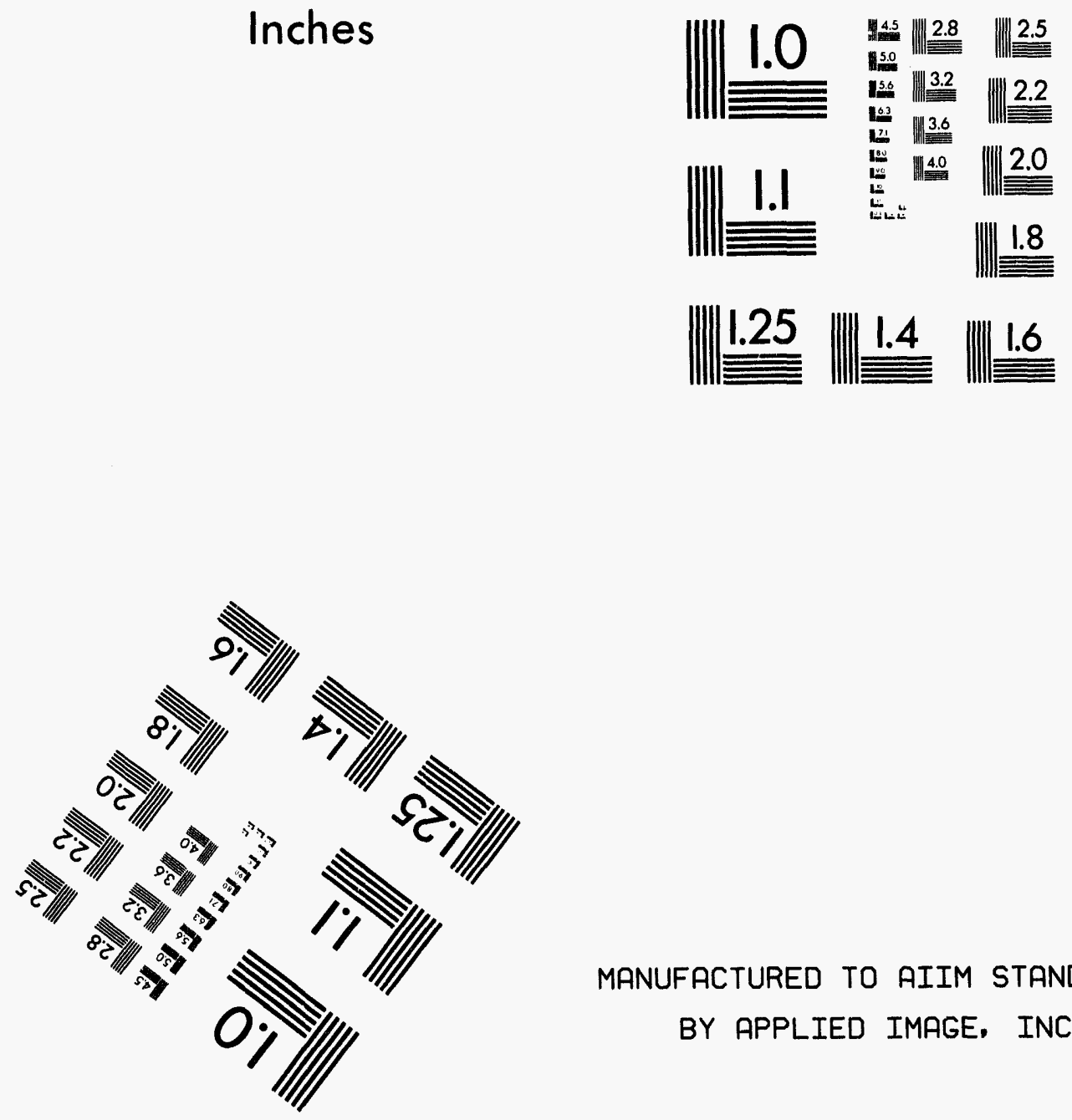

MANUFACTURED TO AIIM STANDARDS

BY APPLIED IMAGE, INC.

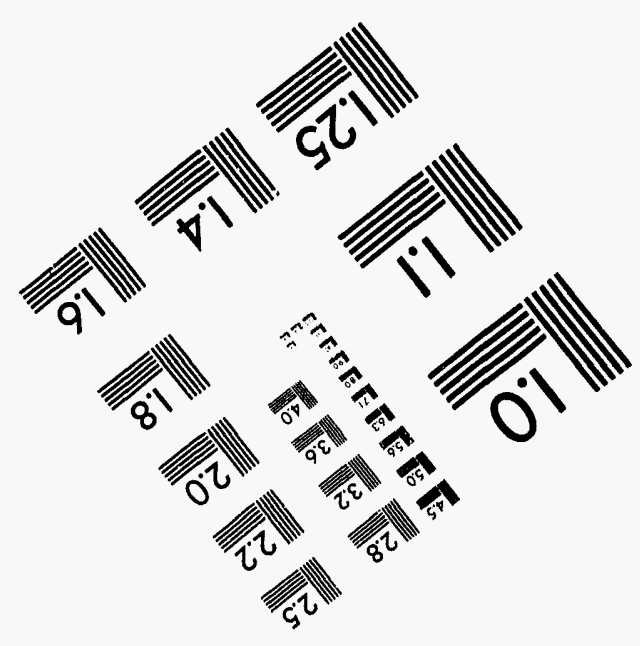



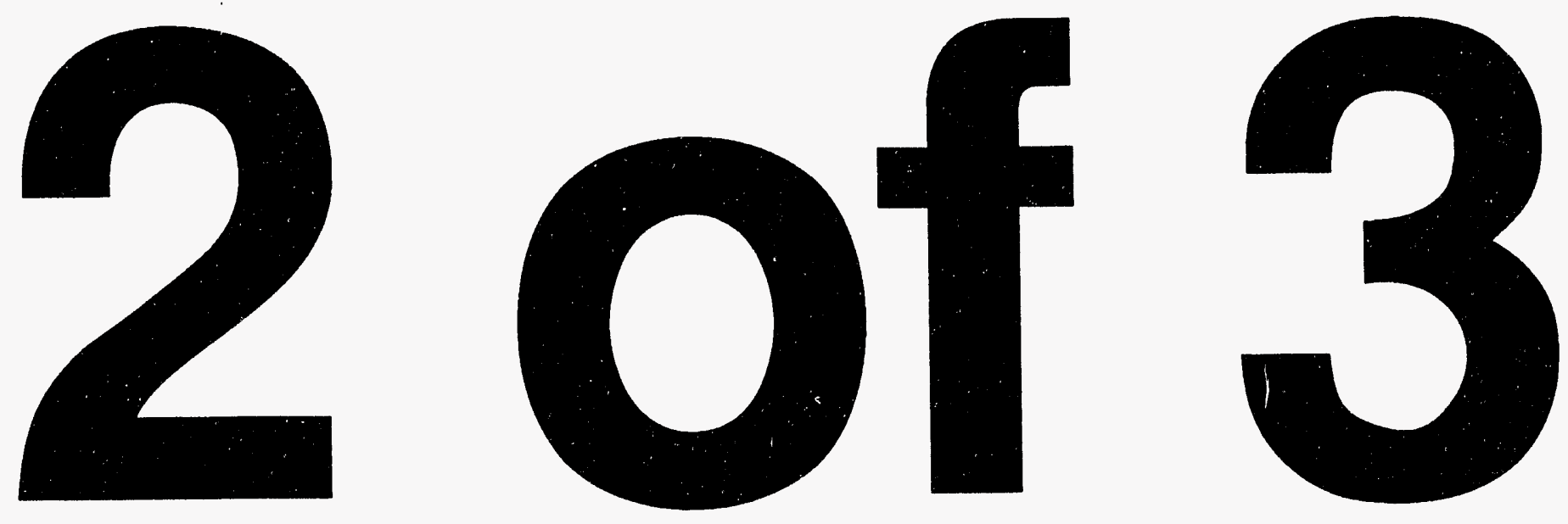
February 16, 1993

February 16, 1993

February 16, 1993

February 16, 1993

February 17, 1993

February 18, 1993

February 22, 1993

February 23, 1993

February 23, 1993
J. Fox, GE, letter forwarding vendor followup action to February 11, 1993, telecon with NRC regarding SSAR Chapter 14, "Initial Test Program," to support accelerated advanced BWR review schedule.

Fiche: 74122:327-74122:333

acn: $\quad 9303040051$

J. Fox, GE, letter forwarding SSAR markups addressing Open Items 5.3.2-1 and 15.3-1, and Confirmatory Items 4.2-3 and 4.4-1 regarding Reactor Systems and Mechanical Engineering Branches outstanding items to support accelerated advanced BWR review schedule.

Fiche: 74136:290-74136:310

acn: $\quad 9303040057$

J. Fox, GE, letter forwarding draft of Chapter 8 that incorporates markup provided under February 9, 1993, letter and more recent markups resulting from telecons since February 9, 1993, to submittal supporting accelerated advanced BWR review schedule. Fiche: 74137:217-74137:303 acn: $\quad 9303040100$

S. Ninh, NRC, letter forwarding proposed agenda for February 22 through 26 audit. Suggests that licensee provide copy of enclosure to NRC and Bechtel to facilitate understanding of scope of audit.

Fiche: 64968:324-64968:325

acn: $\quad 9302190352$

J. Fox, GE, letter forwarding SSAR markups addressing COL Action Items 17.1.1-1, 17.2, 17.3.1-1, 17.3.5-1, and 17.3.9-1. Advises that change reflected in markups in addition to changes proposed in January 19, 1993, letter addressing Open Item 17.3.5-1. Fiche: $\quad 74025: 260-74025: 265$

acn: $\quad 9302250197$

M. Janus, NRC, letter forwarding changes to DFSER Chapter 9 Section 9.3 .5 regarding reliability of suction valves for SLCS, per February 17, 1993, discussion.

Fiche: 64969:139-64969:140

acn: $\quad 9302190355$

J. Fox, GE, letter forwarding report entitled, "Advanced BWR ATWS Stability Study," to address Open Item 4.4-1 and Confirmatory Item 15.5.2-1 to support accelerated advanced BWR review schedule.

Fiche: 74260:265-74260:303

acn: $\quad 9303150200$

J. Fox, GE, letter forwarding SSAR markups revising responses to Open Item 15.3-1 and COL Action Items 17.1.1-1 and 17.2-1 originally transmitted in letters dated February 16 and 17, 1993, supporting accelerated advanced BWR review schedule.

Fiche: 74258:293-74258:297

acn: $\quad 9303150316$

M. Janus, NRC, letter forwarding draft statement of NRC and GE discussions involving valve ITAACs discussed during February 22, 1993, telecon.

Fiche: 71631:331-71631:332

acn: $\quad 9302250116$ 
February 24, 1993

February 24, 1993

February 24, 1993

February 25, 1993

February 25, 1993

February 26, 1993

February 26, 1993

February 26, 1993

March 1, 1993
J. Fox, GE, letter forwarding proposed SSAR markup of Subsection 3.9.6, "Testing of Pumps \& Valves," and Subsection 3.9.7, "COL License Information."

Fiche: 74029:278-74029:288

acn: $\quad 9303010116$

J. Fox, GE, letter forwarding SSAR markup responding to COL Action Item 6.3.4.2-1 and revised Nuclear Boiler System IBD Drawing 137C9464 (SSAR Figure 7.3-2) showing revised $A D S$ logic responding to Confirmatory Item 6.3.3-1 with 38 drawings.

Drawings withheld.

Fiche: 74069:045-74069:048

acn: $\quad 9303010362$

T.H. Boyce, NRC, letter forwarding summary of February 3 and 4, 1993, meeting with GE to discuss lessons learned from January 11 through 21, 1993, meeting on ABWR

ITAAC.

Fiche: $\quad$ 74067:001-74067:143

acn: $\quad 9303030256$

J. Fox, GE, letter forwarding draft of new Appendix 3L, "Procedure for Evaluation of Postulated Ruptures in High Energy Lines," and SSAR markups for Subsections 3.6-1 and 3.6-2, to support accelerated advanced BWR review schedule.

Fiche: 74119:341-74119:357

acn: $\quad 9303040018$

J. Fox, GE, letter forwarding SSAR markups of selected portions of Section 3.11 regarding environ qualification of mechanical and electrical equipment and radiation dose for gamma and beta data, to support advanced BWR accelerated review schedule.

Fiche: $\quad$ 74133:334-74133:348

acn: $\quad 9303040028$

J. Fox, GE, letter forwarding SSAR markups addressing advanced BWR draft FSER COL Action Items 3.3.2-1, 3.5.1.2-1, 3.4.3-1, 3.10-1, and 9.3.5-1, to support accelerated advanced BWR review schedule.

Fiche: 74099:351-74099:360

acn: $\quad 9303040020$ ,

J. Fox, GE, letter forwarding amplification of January 25, 1993, response to Confirmatory Item 15.1-1 regarding verification of ODYNA and REDYA code changes, to support accelerated advanced BWR review schedule

Fiche: $\quad$ 74136:311-74136:312

acn: $\quad 9303040024$

J. Fox, GE, letter forwarding results of analyses of defined set of Chapter 15 events that would bound consequences of postulated common mode failure of microprocessor-based instrumentation and control safety system. Results of six events listed.

Fiche: $\quad$ 74133:215-74133:245

acn: $\quad 9303040065$

J. Fox, GE, letter forwarding responses to G. Kelly December 22, 1992, memo to J. Duncan requesting clarification of information contained in SSAR Subsection 19E.2.3.3 regarding suppression pool bypass paths, to support accelerated advanced BWR review schedule.

Fiche: $\quad$ 74113:320-74113:351

acn: $\quad 9303040054$ 
March 2, 1993

March 3, 1993

March 4, 1993

March 4, 1993

March 4, 1993

March 5, 1993

March 5, 1993

March 5, 1993

March 5, 1993
J. Fox, GE, letter forwarding SSAR markups for Subsections 3.6-2, 3.6-3, 3.6-4, and 3.6-5, in support of accelerated ABWR review schedule for SSAR Section 3.6.

Fiche: 74236:316-74236:333

acn: $\quad 9303110053$

J. Fox, GE, letter forwarding SSAR markups for listed sections covering evalution of control building flooding events, evaluation of turbine building flooding events, and protoction of UHS, to support accelerated advanced BWR review schedule.

Fiche: 74228:309-74228:324

acn: $\quad 9303100202$

J. Fox, GE, letter forwarding responses to questions on advanced BWR probabilistic flooding analysis discussed with G. Kelly on February 22, 1993, and documented in NRC February 25, 1993, letter.

Fiche: $\quad$ 74207:075-74207:086

acn: $\quad 9303100254$

B. Huffman, NRC, letter forwarding markups from Human Factors Branch on advanced BWR ITAAC and Chapter 18, Appendix E of SSAR. Vendor should be prepared to discuss items during March 5, 1993, telecon.

Fiche: 74200:246-74200:291

acn: $\quad 9303090111$

M. Janus, NRC, letter forwarding summary of Chapter 3 issues, "Design of SSC."

Fiche: $\quad$ 74145:344-74145:360

acn: $\quad 9303090606$

J. Fox, GE, letter forwarding detailed presentation of justification and benefits for 'eliminating annulus pressurization and SSE as design load combination for advanced BWR, to support accelerated advanced BWR review schedule.

Fiche: 74207:218-74207:222

acn: $\quad 9303100237$

J. Fox, GE, letter forwarding replacement pages for text provided in February 26, 1993, letter regarding feedwater line break inside containment and shutdown cooling line break inside containment, to support accelerated advanced BWR review schedule.

Fiche: 74207:223-74207:235

acn: $\quad 9303100247$

J. Fox, GE, letter forwarding markup of SSAR Chapter 6 addressing Open Items 6.2.53 regarding containment purging and venting and 6.2.6-6 regarding combustible gas control in containment and COL Action Item 6.2.5-1 regarding alternate hydrogen control.

Fiche: $\quad 74207: 062-74207: 066$

acn: $\quad 9303100259$

J. Fox, GE, letter forwarding SSAR markups in support of accelerated ABWR review schedule for resolution of outstanding items of Section 3.11. Markups withheld.

Fiche: 71643:033-71643:033

acn: $\quad 9303110070$ 
R.C. Mitchell, GE, letter providing key schedule dates for completion of all information required for staff to complete review of ABWR, as follow-up to February 25, 1993, meeting. Licensee will submit final SSAR by July 31, 1993.

Fiche: $\quad$ 74313:293-74313:294

acn: $\quad 9303170239$

March 8, 1993

J. Fox, GE, letter discussing Confirmatory Item 6.1.1-1 which directs vendor to commit to follow EPRI NP-3589-SL-LD, "BWR Water Chemistry Guidelines." Vendor committed to follow 1987 revision to guidelines, and confirmatory item should be closed.

Fiche: $\quad 74336: 354-74336: 354$

acn: $\quad 9303220033$

March 8, 1993

J. Fox, GE, letter forwarding J. Duncan March 8, 1993, memo to NRC responding to NRC questions regarding ECCS pumps taking suction from suppression pool, which during Class II sequences, could exceed pump design basis temperature.

Fiche: 74340:185-74340:187

acn: $\quad 9303220039$

March 8, 1993

J. Duncan, GE, letter responding to NRC questions regarding advanced BWR ECCS pumps taking suction from suppression pool, which during Class II sequences, could exceed pump design basis temperature. Listed material will be placed in SSAR.

Fiche: $\quad 74340: 186-74340: 187$

acn: $\quad 93032200040$

March 8, 1993

J. Fox, GE, letter forwarding J. Duncan March 8, 1993, memo to NRC providing partial response to NRC request that advanced BWR PRA be used to identify important feature of seismic margins, flooding and fire.

Fiche: $\quad 74340: 135-74340: 144$

acn: $\quad 9303220044$

March 8, 1993

J.. Duncan, GE, letter forwarding partial response to NRC request that advanced BWR PRA be used to identify important features regarding seismic margins, flooding and fire, including important insights from advaned BWR seismic margins analysis.

Fiche: $\quad$ 74340:136-74340:144

acn: $\quad 9303220050$

March 8, 1993

J. Fox, GE, letter forwarding replacement of proposed SSAR markup of Subsection 3.9.6, "Testing of Pumps \& Valves," and Subsection 3.9.7, "COL License Info," provided in vendor February 24, 1993, letter. Enclosure incorporates GE understanding of GE/NRC March 5, 1993, vlecon.

Fiche: 74336:325-74336:335

acn: $\quad 9303220055$

March 8, 1993

J. Fox, GE, letter forwarding memo responding to NRC question regarding ECCS pumps taking suction from suppression pool.

Fiche: $\quad 71724: 161-71724: 162$

acn: $\quad 9306090491$

March 9, 1993

J.N. Wilson, NRC, letter discussing review of August 18, 1992, request for withholding information in ABWR SSAR from public disclosure. Informs that only material designated in affidavit for listed subjects is appropriately classified as proprietary.

Fiche: $\quad$ 71641:211-71641:215

acn: $\quad 9303120129$ 
March 9, 1993

March 11, 1993

March 12, 1993

March 12, 1993

March 12, 1993

March 16, 1993

March 16, 1993

March 16, 1993

March 17, 1993
G. Kelly, NRC, retransmits additional ABWR PRA questions, previously sent on January 23, 1993.

Ficho: $\quad 74348: 176-74348: 176$

acn: $\quad 9303220042$

J. Fox, GE, letter forwarding draft SSAR Section 19H.5, "COL License Information," to support accolerated advanced BWR review schedule.

Fiche: 74348:334-74348:339

scn: $\quad 9303220062$

R.W. Borchardt, NRC, letter forwarding assessment of ex-vessel fuel-coolant-interaction energetics for ABWR w/o report.

Fiche: $\quad 74319: 197-74319: 197$

acn: $\quad 9303190186$

G. Kelly, NRC, documents conference call on March 11, 1993, with licensees regarding ECCS pump qualifications and Class II sequences.

Fiche: 74418:338-74418:340

acn: $\quad 9303290164$

G. Kelly, NRC, confirms telecon on March 11, 1993, regarding qualification temp for ECCS pumps.

Fiche: $\quad 71724: 163-71724: 266$

acn: $\quad 9306090510$

J. Fox, GE, letter forwarding proposed changes to SSAR Sections 1.8, 3.8, and 3.9 which address Open Item 14.1.3.8-1 pertaining to welding. Changes reviewed by D. Torao during ITAAC review meeting in San Jose, California, from January 11 through 20, 1993.

Fiche: 74376:202-74376:229

ecn: $\quad 9303250085$

J. Fox, GE, letter forwarding correction to Subsection 3.9.6 and mods to RHR valves F0-14, 015, and 016 discussed during March 16, 1993, telecon. Proposed ITAAC for check valves also enclosed. Information submitted to support accelerated ABWR review schedulo.

Fiche: 74376:354-74376:359

acn: $\quad 9303250088$

J. Fox, GE, letter forwarding GE February 26, 1993, internal memo addressing resolution of Chapter 18 draft FSER outstanding items, initially faxed to NRC on March 12, 1993. Items include validation of detailed design, standard features, and prototype evaluation, and operator workload.

Fiche: 74379:228-74379:234

acn: $\quad 9303250119$

J. Fox, GE, letter forwarding SSAR markups addressing listed DFSER outstanding items. GE recommends that first two sentences of fifth paragraph of DFSER Page 14-18 regarding effect of pipe support stiffness on piping response be replaced, as listed.

Fiche: 74377:318-74377:356

acn: $\quad 9303250149$ 


\section{Appendix C}

March 18, 1993

March 23, 1993

March 23, 1993

March 24, 1993

March 24, 1993

March 24, 1993

March 25, 1993

March 25, 1993

March 26, 1993

March 26, 1993

J. Fox, GE, letter forwarding T. O'Neil's responses to G. Galletti note to M. Ross regarding NRC review of GE ABWR remote shutdown panel inventory of displays, controls, and alarms.

Fiche: 74376:192-74376:193

acn: $\quad 9303250060$

J. Fox, GE, letter forwarding SSAR markups addressing DFSER TMI regarding outstanding Open Items 20.3-6 and 20.3-9 and COL Action Items 20.3-1, 20.3.1-2, 20.3.1-3, 20.3.1-4, 20.3.1-5, and 20.3-2.

Fiche: $\quad$ 74448:340-74448:353

acn: $\quad 9304010178$

J. Fox, GE, letter forwarding proposed wording for Chapter 18 issues based on GE/NRC March 22, 1993, conference call.

Fiche: $\quad 74437: 356-74437: 358$

acn: $\quad 9304010187$

P.W. Marriott, GE, letter forwarding Amendment 26 of selected sections of Chapters 1 through 20 of advanced BWR SSAR.

Fiche: 74398:025-74398:237

acn: $\quad 9303250117$

P.W. Marriott, GE, letter forwarding proprietary Amendment 26 to selected sections of Chapters 1 and 11 of SSAR for advanced BWR.

Fiche: 74385:304-74385:304

acn: $\quad 9303260143$

G. Kelly, NRC, letter providing comments on draft "Important Features from PRA Advanced BWR."

Fiche: $\quad$ 74418:330-74418:336

acn: $\quad 9303290174$

J. Fox, GE, letter forwarding SSAR varkups addressing DFSER Open Items 3.2.1-1, 3.2.1-2, 3.7.2-6, 3.7.2-7, and 3.8.4-1.

Fiche: $\quad 74435: 354-74435: 357$

acn: $\quad 9304010196$

G. Kelly, NRC, letter forwarding comments on response to questions on advanced BWR probabilistic flooding analysis faxed on March 4, 1993.

Fiche: 74418:342-74418:344

acn: $\quad 9303290150$

J. Fox, GE, letter forwarding preliminary version of proposed design certification material covering advanced BWR instrumentation and control (I\&C) issues.

Fiche: $\quad$ 74425:260-74425:292

acn: $\quad 9303300234$

J. Fox, GE, letter forwarding information pertaining to advanced BWR SSAR Section $19 \mathrm{E}$ consequence analysis and vent release points.

Fiche: 74435:358-74435:360

acn: $\quad 9304010203$ 
March 26, 1993

March 29, 1993

March 31, 1993

March 31, 1993

March 31, 1993

March 31, 1993

April 1, 1993

April 2, 1993

April 2, 1993
J. Fox, GE, letter forwarding SSAR markups for Subsection 3.4 on flooding, mentioned to NRC staff at Bethesda ITAAC moetings. Changes address utility request to eliminate curbs andf sills where not required.

Fiche: 74453:313-74453:325

acn: $\quad 9304010207$

J. Fox, GE, letter forwarding SSAR markups providing listed information regarding piping design, to support accelerated ABWR review schedule.

Fiche: 74472:303-74472:313

acn: $\quad 9304060108$

J. Fox, GE, letter forwarding final draft of Section 191, responding to several NRC questions regarding advanced BWR seismic margin analysis.

Fiche: $\quad$ 74471:155-74471:233

acn: $\quad 9304050301$

J. Fox, GE, letter forwarding listed information that address DFSER Chapter 8 outstanding items, to support accelerated ABWR review schedule.

Fiche: 74489:001-74489:226

acn: $\quad 9304060310$

J. Fox, GE, letter forwarding markup of advanced BWR SSAR Chapter 16, Section 3.3, "Instrumentation," and Section 38, "Electrical Power System," per STS (NUREG-1433 and NUREG-1434).

Fiche: $\quad 74604: 001-74605: 083$

acn: $\quad 9304140235$

J.N. Wilson, NRC, letter forwarding PRA and severe accident ITAAC insights guidance document that formalizes process for identifying safety significant insights from ABWR PRA and severe accident evaluations.

Fiche: $\quad 71663: 252-71663: 255$

acn: $\quad 9304050192$

J. Fox, GE, letter forwarding proposed SSAR markup addressing currently evolving BWROG turbine inservice test and inspection surveillance program, to support accelerated ABWR review schedule.

Fiche: $\quad$ 74474:355-74474:357

acn: $\quad 9304060111$

J. Fox, GE, letter forwarding SSAR markups addressing DFSER Confirmatory Items 6.2.5-1, 5.2.5-2, and Open Item 20.3-10. Requests that copy of transmittal be provided to G. Gou.

Fiche: $\quad 74489: 269-74489: 274$

acn: $\quad 9304060426$

J. Fox, GE, letter forwarding SSAR markups that address Open Item 7.1.3.1-1, Confirmatory Item 7.5.2-1 and COL Action Items 7.3.1.11-1, 7.7.1.15-1, and 7.8-1. Requests that copy of transmittal be provided to J. Stewart.

Fiche: $\quad 74484: 212-74484: 221$

acn: $\quad 9304060427$ 
April 2, 1993

April 2, 1993

April 2, 1993

April 5, 1993

April 6, 1993

April 6, 1993

April 6, 1993

April 7, 1993

April 7, 1993
J. Fox, GE, letter forwarding SSAR markup addressing DFFSER COL Action Item 14.1.3.3.7.3-1. Requests that copy of transmittal be provided to $S$. Hou and J.'Brammer.

Fiche: $\quad 74489: 265-74489: 268$

acn: $\quad 9304060429$

J. Fox, GE, letter forwarding SSAR markups addressing DFFSER Confirmatory Item 9.5.1.2.2-1 and COL Action Items 9.5.1.4.6-1 and 20.3.1-1. Requests that copy of transmittal provided to $B$. Burton.

Fiche: $\quad$ 74486:325-74486:351

2cn: $\quad 9304060431$

J. Fox, GE, letter forwarding information addressing Chapters 3 and 5 DFSER Confirmatory Item 3.9.2.3-2 on Page 3-64 of DFSER regarding May 10, 1992, audit commitments, COL Item 3.9.2.3-1 regarding vibration assessment test report and Item 5.2.4-1 regarding PSI and 89 code.

Fiche: $\quad$ 74504:282-74504:289

acn: $\quad 9304070068$

J. Fox, GE, letter forwarding Revision 15 to Engineering Operating Procedure (EOP) 40-300, "Engineering Computer Programs," to he used in conjunction with resolution of Confirmatory Item 15.1-1, "Verification of ODY iv \& REDY Code Changes."

Fiche: 74568:319-74568:331

acn: $\quad 9304120010$

J. Fox, GE, letter forwarding SSAR markups addressing Section 4.2 COL action items regarding testing and summary of test programs and objectives. COL Action Item 14.2.12.3-1 no longer required since corresponding information now included as design requirement.

Fiche: 74668:254-74668:261

acn: $\quad 9304200163$

J. Fox, GE, letter forwarding proprietary SSAR markups addressing DFSER Confirmatory Items 7.2.1-1 and 7.2.2.1-3.

Fiche: 74621:309-74681:317

acn: $\quad 9304200183$

J. Fox, GE, letter forwarding GE engineering operating procedures (EOPs), referenced in EOP 40.300 and provided in author April 5, 1993, letter in conjunction with resolution of Confirmatory Item 15.1-1.

Fiche: $\quad 74675: 280-74675: 335$

acn: $\quad 9304210050$

J. Fox, GE, letter forwarding markups of HFE Tier 1 information and SSAR Appendix $18 E$, advanced BWR human-machine interface design implementation process.

Fiche: $\quad 75555: 167-74555: 221$

acn: $\quad 9304090313$

J. Fox, GE, letter forwarding marked-up TS 3.3.5.1 regarding ECCS instrumentation, initially provided in March 31, 1993, letter to support accelerated advaned BWR review schedule.

Fiche: $\quad 74559: 350-74559: 358$

acn: $\quad 9304120014$ 
April 8, 1993

April 8, 1993

April 9, 1993

April 9, 1993

April 9, 1993

April 12, 1993

April 13, 1993

April 14, 1993

April 16, 1993
J. Fox, GE, letter forwarding SSAR markup addressing draft FSER Open Item 7.7.1.151 regarding design of plant security system and design basis for sound-powered telephone system, to support accelerated advanced BWR review schedule.

Fiche: 74603:258-74603:262

acn: $\quad 9304140224$

J. Fox, GE, letter forwarding markups addressing draft FSER Chapter 18 outstanding items regarding design goals and design basis planning, development and design, control room standard design features and remote shutdown system.

Fiche: 74606:346-74606:357

acn: $\quad 9304140289$

P.W. Marriott, GE, letter correcting discrepancy in proprietary classification for interlock block diagrams, radwaste bldg arrangements and P\&IDs of advanced BWR SSAR Chapters 1, 11, and 12, and SAFER/GESTAR LOCA analysis results, per NRC March 9, 1993, request.

Fiche: $\quad 74577: 357-74577: 359$

acn: $\quad 9304130329$

J. Fox, GE, letter forwarding SSAR markup addressing draft FSER Open Item 8.3.5-1 regarding dc emergency lighting (Class 1E dc power supply) per April 7, 1993, telecon, to support accelerated advanced BWR review schedule.

Fiche: 74608:346-74608:347

acn: $\quad 9304140227$

J. Fox, GE, letter forwarding SSAR markups addressing draft FSER Open Item 9.4.6-1 w/three oversize figures. Fiche:74620:357-74620:359

acn: $\quad 9304140357$

J. Fox, GE, letter forwarding markup of draft FSER Confirmatory Item 7.2.1-2, consisting of Table 1.8-22, "Experience Applicable to ABWR," to support accelerated ABWR review schedule.

Fiche: $\quad 74677: 330-74677: 331$

acn: $\quad 9304190058$

J. Fox, GE, letter forwarding markup showing proposed mods to February 12, 1993, submittal of Section 14.2 which responded to Open Items 14.2.12.3-1 and 14.2.12.3-2, to support accelerated advanced BWR review schedule.

Fiche: $\quad 74620: 143-74620: 211$

acn: $\quad 9304160033$

J. Fox, GE, letter forwarding SSAR markup addressing draft final SER, Confirmatory Item 7.6.1.3-1 regarding instrumentation and controls for process radiation monitoring system and high pressure/low pressure system interlock protection functions.

Fiche: $\quad 74744: 354-74744: 355$

acn: $\quad 9304260199$

J. Fox, GE, letter forwarding SSAR markup addressing DFSER Open Item 2.6-1, including consideration of issues identified in Section 1.4 of EPRI Evolutionary Plant SER. Enclosure markup Table 2.0-1 submitted in support of accelerated ABWR review schedule.

Fiche: $\quad 74743: 356-74743: 357$

acn: $\quad 9304260135$ 
Appendix C

April 16, 1993

J. Fox, GE, letter forwarding SSAR markups addressing draft FSER Chapter 12 outstanding items regarding radiation sources, radiation protection features, health physics program, and compliance with RG 8.8.

Fiche: $\quad 74746: 262-74746: 277$

acn: $\quad 9304260215$

April 16, 1993

J. Fox, GE, letter forwarding responses to draft final SER TS items, in support of accelerated ABWR review schedule.

Fiche: 74744:358-74744:361

acn: $\quad 9304260232$

April 16, 1993

J. Fox, GE, letter forwarding SSAR markup of Chapter 14 regarding startup testing.

Fiche: 74762:107-74762:259

acn: $\quad 9304270056$

April 19, 1993

J. Fox, GE, letter forwarding information to support accelerated ABWR review schedule for Chapter 3 of draft FSER Open Items 3.9.3.1-2 and 14.1.3.3.5.10-1 regarding thermal striping.

Fiche: 74820:012-74820:022

acn: $\quad 9305030001$

April 19, 1993

G. Kelly, NRC, letter forwarding thoughts put together from comments received from contractor on advanced BWR shutdown analysis.

Fiche: $\quad$ 74707:333-74707:337

acn: $\quad 9304220194$

April 20, 1993

J. Fox, GE, letter forwarding Lovel 2 design review reports from independent design verification packets for ODYNA and REDYA computer codes, per request during April 19, 1993, telecon supporting closure of draft FSER Confirmatory Item 15.1-1.

Fiche: $\quad$ 74820:001-74820:011

acn: $\quad 9305030016$

April 20, 1993

J. Fox, GE, letter forwarding SSAR markup of TS LCO 3.3.2.2 regarding operability of feedwater and main turbine trip instrumentation necessary to close draft final SER TS Item 15.1-1.

Fiche: $\quad$ 71693:294-71693:304

acn: $\quad 9305030132$

April 21, 1993

J. Fox, GE, letter forwarding mods to selected pages from Attachment 3 to March 31, 1993, letter, consisting of Table 1.8-21, "Industrial Codes \& Standards Applicable to Advanced BWR," agreed upon in April 21, 1993, telecon.

Fiche: 74741:201-74741:205

acn: $\quad 9304230042$

April 21, 1993

J. Fox, GE, letter forwarding SSAR Figures 7.2-7, revised Figures 7.2-9 and 7.2-10 in response to DFSER Confirmatory Item 7.2.1-4 regarding incomplete drawing and electrical connections.

Fiche: 98503:001-98503:085

acn: $\quad 9304260124$

April 21, 1993

G. Kelly, NRC, letter forwarding information gathered from comments received from NRC contractor on ABWR internal flooding analysis.

Fiche: $\quad$ 74739:338-74739:341

acn: $\quad 9304260026$ 
April 22, 1993

April 22, 1993

April 22, 1993

April 22, 1993

April 23, 1993

April 23, 1993

April 23, 1993

April 23, 1993

April 23, 1993

April 23, 1993
J. Fox, GE, letter forwarding draft of revised Appendix 18F addressing DFSER Confirmatory Item 18.4.3-1.

Fiche: $\quad$ 74743:292-74743:310

acn: $\quad 9304260137$

J. Fox, GE, letter forwarding information which compares insights examples provided by C. Buchholz (GE) to NRC February 16, 1993, examples sent by B. Palla to GE on March 24, 1993. Information may be useful to NRC in preparation for GE NRC April 26, 1993, meeting.

Fiche: $\quad 74744: 332-74744: 341$

acn: $\quad 9304260142$

J. Fox, GE, letter forwarding justification of three independent ECCS subsistems which addresses DFSER Open Item 16-3.

Fiche: $\quad$ 74744:356-74744:357

acn: $\quad 9304260147$

C. Tang, GE, letter forwarding revised LCO and bases for TS 3.1.5 operability for each control rod scram accumulator.

Fiche: $\quad 74819: 100-74819: 110$

acn: $\quad 9305030291$

J. Fox, GE, letter forwarding SSAR markup addressing draft FSER Open Item 3.10.3-1.

Fiche: 74807:339-74807:347

acn: $\quad 9304300362$

J. Fox, GE, letter forwarding SSAR markup addressing draft Confirmatory Items 7.2.51 and 7.2.5-2.

Fiche: $\quad 74806: 350-74806: 353$

acn: $\quad 9304300363$

J. Fox, GE, letter forwarding updated version of Sections 16.0 and 16.1 addressing COL Action Item 16-1.

Fiche: $\quad 74806: 344-74806: 346$

acn: $\quad 9304300365$

J. Fox, GE, letter fprwarding replacement pages 18F-14 and Table 18F-23 of April 22, 1993, submittal supporting accelerated advanced BWR review schedule on draft SER Confirmatory Item 18.4.3-1.

Fiche: $\quad$ 74806:347-74806:349

acn: $\quad 9304300367$

J. Fox, GE, letter forwarding composite of advanced BWR containment event tree material, replacing information currently contained in Section 19D.5 of SSAR.

Fiche: 74807:258-74807:327

acn: $\quad 9304300373$

R.C. Mitchell, GE, letter forwarding Central Files version of Amendment 27 to GE ABWR SSAR, proprietary information for sections of Chapter 1,6 , and 11 regarding plant description, safety features, and waste management, respectively.

Fiche: 74853:097-74853:097

acn: $\quad 9305060069$ 
April 23, 1993

April 26, 1993

April 26, 1993

April 26, 1993

April 26, 1993

April 26, 1993

April 27, 1993

April 27, 1993

April 28, 1993

April 28, 1993
R.C. Mitchell, GE, letter forwarding public version of Amendment 27 to ABWR SSAR as result of first phase of SSAR verification activity. Charges primarily clarifications, w/o new information.

Fiche: $\quad 74850: 142-74852 L: 217$

ocn: $\quad 9305060184$

J. Fox, GE, letter forwarding revised versions of advanced BWR Tier 1 ITAAC material reviewed during January 11 through 21, and March 8 through 12, 1993, GE/NRC meetings. Written dispositions of punch list items from January and March meetings also enclosed.

Fiche: $\quad 74776: 001-74776: 243$

acn: $\quad 9304300245$

J. Fox, GE, letter forwarding replacement markups to April 23, 1993, letter addressing draft final SER Confirmatory Items 7.2.5-1 and 7.2.5-2.

Fiche: $\quad$ 74774:335-74774:339

ucn: $\quad 9304300259$

J. Fox, GE, letter forwarding modification to page 15 of Attachment 4 to March 31 , 1993, letter regarding draft final SER Chapter 8.

Fiche: $\quad 74774: 340-74774: 341$

acn: $\quad 9304300261$

J. Fox, GE, letter forwarding SSAR markups addressing Open Items 3.8.4-2 and 6.2. $\overline{6}$. and COL Action Item 3.8.4-1 regarding other seismic Category I structures, structural integrity pressure resut and potential bypass leakage paths.

Fiche: $\quad$ 74818:001-74818:123

acn: $\quad 9305030014$

J. Fox, GE, letter forwarding revision to January 18, 1993, markup addressing draft FSER Open Item 9.3.3.2-1 regarding samples of radiation levels, to support accelerated ABWR review.

Fiche: $\quad 74820: 023-74820: 024$

acn: $\quad 9305030018$

J. Fox, GE, letter forwarding SSAR markup addressing draft final SER Confirmatory Item 7.4.1.1-2.

Fiche: $\quad 74774: 351-74774: 352$

acn: $\quad 9304300233$

J. Fox, GE, letter forwarding modified Subsection 6.1.1.1.3.4, reflecting references to RGs 1.36 and 1.82, with regard to ABWR thermal insulation.

Fiche: $\quad 74779: 210-74779: 352$

acn: $\quad 9304300254$

C. Tang, GE, letter forwarding revised TS 3.1.5, "Control Rod Scram Accumulators," reflecting results of NRC discussion with Rose.

Fiche: $\quad$ 74832:272-74832:282

acn: $\quad 9305040323$

J. Fox, GE, letter forwarding SSAR markup addressing draft FSER Open Item 1.2.6-1 regarding standard plant scope and site plan.

Fiche: $\quad$ 74864:316-74864:319

acn: $\quad 9305070354$ 
April 28, 1993

April 28, 1993

April 29, 1993

April 29, 1993

April 29, 1993

April 29, 1993

April 30, 1993

April 30, 1993

April 30, 1993
J. Fox, GE, letter forwarding replacement pages for Attachment 1 to March 31, 1993, letter for draft final SER Confirmatory Item 8.3.2.8-1 and Open Item 8.3.3.5-1. Corresponding SSAR markups also enclosed.

Fiche: $\quad$ 74862:220-74862:228

acn: $\quad 9305100032$

J. Fox, GE, letter forwarding SSAR markup adding Revision 2 to NUREG-0313.

Revision inadvertently removed on Amendment 15.

Fiche: $\quad$ 74862:357-74862:358

acn: $\quad 9305100038$

R.C Mitchell, GE, letter forwarding Amendment 27, page change instruction for Chapter 1, "Introduction \& General Description of Plant," Chapter 5, "Reactor Coolant Systems...," Chapter 6, "Engineered Safety Features," Chapter 8, "Electric Power," and Chapter 9.

Fiche: 74854:001-74854:106

acn: $\quad 9305050169$

R.C. Mitchell, GE, letter forwarding proprietary Amendment 27 to ABWR SSAR, consisting of $11 \times 17$ foldout drawings.

Fiche: 74848246-74848:247

acn: $\quad 9305050177$

J. Fox, GE, letter discusses draft final SER Open Item 1.1-1, with respect to December 15, 1992, SRM regarding SECY-89-334, "Recommended Priorities for Review of Std Plant Designs." GE believes ABWR SSAR satisfies objectives of policy guidance provided by subject SRM.

Fiche: $\quad$ 74862:218-74862:219

acn: $\quad 9305100044$

I. Selin, NRC, letter responding to licensee April 6, 1993, letter commenting on importance of completing reviews of both ABWR and System $80+$ designs as quickly as possible.

Fiche: 74835:084-74835:086

acn: $\quad 9305060342$

C. Tang, GE, letter forwarding SLC system revised TS SR 3.1.7.7 on pages 3.1-23 and 'B 3.1-42.

Fiche: 74835:318-74835:321

acn: $\quad 9305050115$

J. Fox, GE, letter forwarding SSAR marrkups addressing Open Item 7.2.6-1, 7.2.6-2,

7.2.6.4, 7.2-8-1, 7.7.1.15-2, and Confirmatory Items 7.2.1-3, 7.2.2.2-1, 7.2.2.5-1,

7.2.8-2, 7.2.8-3, 7.2.8-5, 7.3.2-1 and 7.4.1.4-1.

Fiche: $\quad 74866: 188-74866: 243$

acn: $\quad 9305070263$

J. Fox, GE, letter forwarding SSAR markups addressing draft FSER Open Item 3.8.3-1 and COL Action Item 9.4.8-1 regarding drywell equipment and pipe support structure and reactor shield wall stabilizer.

Fichs: 74870:096-74870:105

acn: $\quad 9305070344$ 


\section{Appendix C}

April 30, 1993

April 30, 1993

April 30, 1993

April 30, 1993

April 30, 1993

April 30, 1993

April 30, 1993

April 30, 1993

April 30, 1993

April 30, 1993
J. Fox, GE, letter forwarding SSAR markups addressing Confirmatory Items 3.6.1-2, 6.2.1.7-1 and response to Open Item 6.2.1.6-3. Response to question on Subsection 6.2.1.2.2 regarding design features also enclosed.

Fiche: 74870:046-74870:094

acn: $\quad 9305070351$

J. Fox, GE, letter forwarding SSAR markups addressing draft FSER Action Item 1.1.2.1-1, Open Items 1.2.2-1 and 1.2.2-2 regarding common engineering design control process.

Fiche: $\quad 74870: 043-74870: 045$

acn: $\quad 9305070353$

J. Fox, GE, letter forwarding SSAR markup and Appendix 1C, "Advanced BWR Station Blackout Considerations," addressing draft FSER Confirmatory Item 9.2.13-1.

Fiche: 74865:001-74865:021

acn: $\quad 9305070355$

J. Fox, GE, letter forwarding draft replacement for Appendix 19B, "Assessment of Applicable USIs \& GSIs," addressing Open Items 20.1-1 and 20.2-1.

Fiche: $\quad 74870: 158-74870: 243$

acn: $\quad 9305100002$

J. Fox, GE, letter forwarding updated Table 1.9-1, "Summary of ABWR Std Plant COL License Info," addressing draft final SER Open Item 1.9-1.

Fiche: $\quad$ 74862:205-74862:217

acn: $\quad 9305100004$

J.N. Fox, GE, letter forwarding SSAR markups for minor revisions to January 28, 1993, OBE elimination submittal, consisting of draft final SER Open Items 3.1-1 and 14.1.3.3.5.15-1, and SSAR markup to expand definition of pipe supports identified as ' "Limit Stops."

Fiche: $\quad 74866: 311-74866: 316$

acn: $\quad 9305100015$

J. Fox, GE, letter forwarding SSAR markup and replacements for Tables 31.3-9 through 3I.3-13 and Tables 31.3-19 through 3I.3-22 addressing draft final SER Open Item 3.11.3-1.

Fiche: $\quad 74862: 193-74862: 204$

acn: $\quad 9305100019$

J. Fox, GE, letter submits summary of results of GE review of issues identified in GE HFE Program Review Model, addressing Open Item 18.9.2.2.1-1, provided to NRC in transmittal dated August 13, 1992.

Fiche: $\quad 74862: 191-74862: 192$

acn: $\quad 9305100021$

J. Fox, GE, letter forwarding SSAR markup and new Appendix 1B, "Comparison of US ABWR \& K-6/7 Difference," addressing draft final SER Confirmatory Item 1.2-1.

Fiche: $\quad 74862: 178-74862: 190$

acn: $\quad 9305100022$

J. Fox, GE, letter forwarding "Resolution ISLOCA for ABWR," addressing DFSER Open Items 5.4.7-2 and 20.2-3.

Fiche: $\quad 74902: 083-74902: 146$

acn: $\quad 9305130045$ 
May 3, 1993

May 3, 1993

May 3, 1993

May 4, 1993

May 5, 1993

May 5, 1993

May 5, 1993

May 7, 1993

May 7, 1993

May 7, 1993
J. Fox, GE, letter forwarding replacement page for Table 6.2-4, originally included in April 30, 1993, transmittal addressing draft final SER Confirmatory Item 6.2.1.7-1.

Fiche: 74870:041-74870:042

acn: $\quad 9305070254$

J. Fox, GE, letter forwarding drawings regarding containment overpressure protection.

Fiche: $\quad$ 74875:338-74875:343

acn: $\quad 9305110095$

J. Fox, GE, ietter forwarding correction to April 27, 1993, letter, correcting marked up Subsection 6.1.1.1.3.4 regarding ABWR thermal insutation to reflect "not" in third sentence.

Fiche: $\quad 74954: 236-74954: 237$

scn: $\quad 9305170216$

J. Fox, GE, letter forwarding omitted issues from April 30, 1993, transmittal, including second page of GSI 142 in support of accelerated ABWR review schedule regarding USIs and GSIs.

Fiche: $\quad$ 74875:324-74875:337

acn: $\quad 9305110105$

J. Fox, GE, letter forwarding GE understanding of April 26, 1993, telecon between GE and NRC on SSAR Chapter 4 and Tier 1 for review regarding acceptability.

Fiche: 74898:323-74898:324

acn: $\quad 9305130022$

J. Fox, GE, letter forwarding SSAR markup for draft final SER Open Item 19.1.6.4-1, supplementing April 16, 1993, telecon.

Fiche: $\quad 74898: 353-74898: 354$

acn: $\quad 9305130029$

R.W. Borchardt, NRC, letter discussing review of April 9, 1993, letter providing response to preliminary evaluation of information in advanced BWR SSAR classified as proprietary information by GE Nuclear Energy.

Fiche: $\quad 74870: 268-74870: 269$

acn: $\quad 9305110274$

J. Fox, GE, letter forwarding SSAR markup addressing draft final SER Open Items 3.7.2-8 and 3.7.2-9, per markup dated January 30, 1993.

Fiche: 74901:069-74901:075

acn: $\quad 9305130008$

J. Fox, GE, letter forwarding SSAR markups addressing draft final SSAR Section 14.2 outstanding items to clarify role of start-up administrative manual and scoping documents, per April 6, 1993, letter.

Fiche: 74901:080-74901:091

acn: $\quad 9305130014$

J. Fox, GE, letter forwarding SSAR markup showing alternate path to discharge excess water to main condenser rather than to suppressing pool, per discussions w/ B. Burton and J. Lyons at April 13 through 15, 1993, meeting with NRC in San Jose, California. Fiche: $\quad 74900: 348-74900: 355$

acn: $\quad 9305130016$ 
Appendix C

May 7, 1993

May 7, 1993

May 7, 1993

May 7, 1993

May 11, 1993

May 11, 1993

May 11, 1993

May 11, 1993

May 11, 1993

May 11, 1993

Item 6.2.5-3, supplementing March 3, 1993, letter.

Fiche: 74898:355-74898:359

acn: $\quad 9305130017$

J. Fox, GE, letter forwarding SSAR markups proposed for overpressure protection system.

Fiche: 74901:044-74901:057

acn: $\quad 9305130020$

J. Fox, GE, letter forwarding responses to Audit Items 3 and 11 of February 22, 1993 and November 13, 1993, audit reports, respectively.

Fiche: $\quad 74898: 325-74898: 352$

acn: $\quad 9305130032$

- J. Fox, GE, letter forwarding SSAR markup addressing Section 3.7 issues of February 22, 1993, audit report. Markup includes Audit Items 3 and 11 responses, November 11, 1993, and Fobruary 22, audit reports, respoctively.

Fiche: 74930:334-74931:078

acn: $\quad 9305130132$

J. Fox, GE, letter forwarding SSAR markups regarding valve operability assurance, reflecting reflecting resolution obtained in May 3, 1993, telecon.

Fiche: 74951:333-74951:340

acn: $\quad 9305180188$

J. Fox, GE, letter forwarding SSAR markups to improve/clarify Section 3.10, "Seismic Qualification of Seismic Category I Instrumentation \& Electrical Equipment (Including Other Dynamic Loads)."

Fiche: 74951:061-74951:065

scn: $\quad 9305180193$

J. Fox, GE, letter forwarding SSAR markups to Chapter 8 material that resulted from GE/NRC May 7, 1993, telecon.

Fiche: $\quad$ 74957:141-74957:160

acn: $\quad 9305180296$

J. Fox, GE, letter forwarding replacement page (page 3 of 13) for overpressure protection system SSAR markup of May 7, 1993, letter.

Fiche: 74957:081-74957:082

acn: $\quad 9305180300$

J. Fox, GE, letter forwarding drafts of TS 3.3.8.1, "Loss of Power Instrumentation," and 3..3.8.2, "Vital AC Electric Power Monitoring."

Fiche: 74952:001-74952:023

acn: $\quad 9305180306$

J. Fox, GE, letter forwarding report entitled, "Condensation-Induces Water Hammer Evaluation for ABWR ECCS Piping," which will be referenced in GE resolution of USI A-1, "Water Hammer."

Fiche: $\quad 74950: 001-74950: 035$

acn: $\quad 9305180314$ 
May 11, 1993

May 12, 1993

May 12, 1993

May 13, 1993

May 13, 1993

May 13, 1993

May 13, 1993

May 14, 1993

May 14, 1993
J. Fox, GE, letter forwarding SSAR markups for draft FSER outstanding issues in Chapter 7 regarding main steamline high flow monitoring (for leaks downstream of flow elements and fuel zone water level range).

Fiche: 74951:341-74951:361

acn: $\quad 9305180365$

J. Fox, GE letter forwarding SSAR markups addressing Open Issues 3.7.2-2 and 3.8.4-3 and COL Action Item 3.8.3-1, previously addressed as part of GE April 26, 1993, letter.

Fiche: $\quad 74951: 066-74951: 071$

acn: $\quad 9305180187$

J. Fox, GE, letter forwanding SSAR markup addressing COL Action Item 9.5.1.5-1 regarding fire-related administrative controls.

Fiche: 74963:349-74963:352

acn: $\quad 9305190272$

J. Fox, GE, letter forwarding responses to NRC questions on flooding PRA transmitted by GE by letters dated March 25 and April 12, 1993.

Fiche: 74970:182-74970:197

acn: $\quad 9305190275$

GE, letter forwarding SSAR markup modifying response given in April 16, 1993, letter regarding draft FSER COL Action Item 12.5.1-1 regarding operational considerations.

Fiche: 74982:236-74982:237

acn: $\quad 9305190279$

J. Fox, GE, letter forwarding marked-up SSAR Section 14.2, per NRC comments made during April 20, 1993, telecon. Comments cover feedwater control system preoperational test, standby gas treatment system preoperational test and containment isolation valve leakage rate tests.

Fiche: $\quad 74987: 329-74989: 358$

acn: $\quad 9305200121$

D. Crutchfield, NRC, letter discussing results of work between NRC and GE to establish an acceptable minimum inventory of fixed-position controls, displays and alarms over two-year period.

Fiche: 75021:268-75021:271

acn: $\quad 9305250238$

P.W. Marriott, GE, letter forwarding documents regarding radiation protection. Documents provided by GE March 9, 1992, letter in support of ABWR SSAR Chapter 12 at NRC request. Documents originally considered proprietary. Documents being reissued as Class 1.

Fiche: 74940:001-74942:005

acn: $\quad 9305180107$

J. Fox, GE, letter forwarding SSAR markups addressing questions raised at May 11, 1993, GE/NRC conference call regarding Subsection 3..5.1.1, "Internally Generated Missiles (Outside Containment)."

Fiche: 74970:163-74970:167

acn: $\quad 9305200028$ 
May 14, 1993

May 14, 1993

May 14, 1993

May 14, 1993

May 17, 1993

May 18, 1993

May 18, 1993

May 19, 1993

May 19, 1993

May 19, 1993
J. Fox, GE, letter forwarding modification to GE response to draft FSER Open Item 3.7.2-2 regarding support of deadweight of equipment and piping transmitted via author May 12, 1993, letter.

Fiche: $\quad 74970: 170-74970: 171$

scn: $\quad 9305200029$

J. Fox, GE, letter forwarding SSAR markup regarding qualification by experience, per May 14, 1993, telecon with D. Terao.

Fiche: $\quad 74987: 317-74987: 320$

acn: $\quad 9305200113$

P.W. Marriott, GE, letter forwarding proprietary Appendix 19F, Sections 19F.1 through 19FA.2 of SSAR for ABWR. Proprietary enclosure withheld.

Fiche: 74987:189-74987:190

acn: $\quad 9305200136$

P.W. Marriott, GE, letter forwarding Amendment 28 to nonpropra tary sections o. Chapter 19, "Response to Severe Accident Policy Statement," of ABWR SSAR.

Fiche: 74968:001-74970:119

acn: $\quad 9305200149$

C. Tang, GE, letter forwarding revised Section 19.1.9.1, CUW line break procedure, per May 10, 1993, telecon.

Fiche: 74976:301-74976:304

acn: $\quad 9305200122$

J. Fox, GE, letter forwarding listed information to support accelerated advanced BWR review schedule for USIs and GSIs, including GI A-1, A-10, and A-17, based on May 6, 1993, telecon.

Fiche: 74988:038-74988:059

acn: $\quad 9305200211$

J. Fox, GE, letter forwarding SSAR markups of new Appendix 3L and Report GE-NE123-E070-0493, "Sample Analysis for Effect of Postulated Pipe Break ABWR Main Steam Piping," App 3L markups address NRC comments.

Fiche: $\quad$ 74999:056-74999:116

acn: $\quad 9305210053$

J. Fox, GE, letter forwarding submittal supporting accelerated ABWR review schedule regarding effect of changing concrete tensile strength from 100 psi to 10 psi.

Fiche: 75011:311-75011:312

acn: $\quad 9305250156$

J. Fox, GE, letter forwarding submittal supporting accelerated ABWR review schedule regarding audit item 2 associated with wind loading.

Fiche: 75011:327-75011:331

acn: $\quad 9305250168$

J. Fox, GE, letter forwarding SSAR markup of revised LCO 3.7.5, "Main Bypass

System," supporting accelerated ABWR review schedule.

Fiche: 75011:313-75011:322

acn: $\quad 9305250177$ 
May 19, 1993

May 19, 1993

May 20, 1993

May 21, 1993

Míay 21, 1993

May 21, 1993

May 21, 1993

May 21, 1993

May 21, 1993

May 21, 1993

J. Fox, GE, letter forwarding draft composite of Revision B to 23A6100AE, "Advanced BWR Standard Plant SSAR."

Fiche: 75011:280-75011:291

acn: $\quad 9305250182$

J. Fox, GE, letter forwarding revised pages to App 3A, "Seismic Soil Structure

Interaction Analysis."

Fiche: $\quad 75015: 206-75015: 238$

acn: $\quad 9305250204$

J. Fox, GE, letter forwarding Sections 1, 2, 4, and 5 and pages B3.3-75 and B3.3-91 to advanced BWR TS previously omitted.

Fiche: 75063:243-75063:309

acn: $\quad 9305280187$

R.C. Mitchell, GE, letter forwarding revised versions of selected advanced BWR Tier 1/TTAAC material for advanced BIVR system and proposed Tier 1 entries for design reliability assurance program and initial test program.

Fiche: 75034:001-75034:210

acn: $\quad 9305260197$

J. Fox, GE, letter forwarding SSAR markups providing clarifications requested in May 19, 1993, telecon regarding feedwater piping classification and use of special engineered pipe supports, to support accelerated ABWR review schedule for Chapter 3.

Fiche: 75077:267-75077:272

acn: $\quad 9306010134$

J. Fox, GE, letter forwarding info regarding COL Open Item 7.2.6-3 on shared use of EMS and provision of operator info and time to manually mitigate accident, inadvertently omitted from April 30, 1993, letter.

Fiche: $\quad$ 75077:273-75077:274

acn: $\quad 9306010141$

J. Fox, GE, letter forwarding draft version of SSAR addressing COL Action Items 9.3.3-1 and 9.3.8-1 regarding safety design bases and sate design bases (interface requirements), respectively.

Fiche: 75083:190-75083:193

acn: $\quad 9306020223$

J. Fox, GE, letter forwarding SSAR markups providing Chapter 14 clarifications regarding initial test program, per May 21, 1993, discussions with NRC.

Fiche: 75083:201-75083:204

acn: $\quad 9306020232$

J. Fox, GE, letter forwarding SSAR markups for May 17, 1993, conference call regarding clarification of Chapter 1 and 9, consisting of Table 3.4-1, "Structures, Penetrations \& Access Openings Designed for Flood Protection."

Fiche: $\quad$ 75083:214-75083:224

acn: $\quad 9306020278$

J. Fox, GE, letter forwarding response to inquiries regarding Amend 27 covering suppression pool cooling.

Fiche: $\quad$ 75082:333-75082:336

acn: $\quad 9306020279$ 
May 24, 1993

Muy 24, 1993

May 25, 1993

May 26, 1993

May 26, 1993

May 26, 1993

May 26, 1993

May 26, 1993

May 26, 1993

May 27, 1993
J. Fox, GE, letter forwarding submittal supporting accelerated advanced BWR review schedule - LCO 3.10.11.

Fiche: 75077:341-75077:348

acn: $\quad 9306010207$

J. Fox, OE, letter forwarding SSAR markup of TS Section B3.0 regarding LCOs.

Fiche: 75091:211-75091:225

acn: $\quad 9306020344$

J. Fox, GE, letter forwarding C.E. Buchholz May 21, 1993, memo closing all issues discussed at April 25, 1993, meeting except insights/Tier 2/Tier 1.

Fiche: $\quad 75122: 310-75122 \mathrm{~L}: 332$

acn: $\quad 9306030196$

J. Fox, GE, letter forwarding replacements to SSAR markups of Appendix 3L and to report GE-NE-123-E070-0493, "Sample Analysis for Effect of Postulated Pipe Break Advanced BWR Main Steam Piping," provided in May 18, 1993, letter.

Fiche: 75091:001-75091:062

acn: $\quad 9306020259$

J. Fox, GE, letter forwarding markup of composite changes to Table 3.9-8 regarding inservice testing, safety-related pumps and valves. No changes made to table since Amendment 27.

Fiche: $\quad 75117: 318-75117: 324$

acn: $\quad 9306030076$

J. Fox, GE, letter forwarding SSAR markup addressing Item 9.4.1(1) of May 25, 1993, telocon regarding control building HVAC.

Fiche: 75117:045-75117:056

acn: $\quad 9306030079$

K. Gregoire, GE, letter lists documents used as representative set of inputs for characterizing lessons learned from operating experience in previous nuclear plant designs.

Fiche: $\quad 75117: 356-75117: 356$

acn: $\quad 9306030208$

G.E. Miller, GE, letter forwarding answers to queries in telecons on May 25 and 26, 1993, regarding ABWR SSAR.

Fiche: $\quad$ 75952:248-74952:249

acn: $\quad 9307220098$

D. Crutchfield, NRC, letter discussing GE March 5, 1993, request for deviation regarding ABWR design basis loading combinations. NRC has not endorsed use of probabilistic approach as basis for decoupling SSE \& LOCA loading combination. Response requested.

Fiche: $\quad 75143: 278-75143: 280$

acn: $\quad 9306070141$

J. Fox, GE, letter forwarding SSAR markups to Chapter 8 material, resulting from GE/NRC May 24, 1993, telecon covering motor control centers, 120-v/240-v distribution system, 120-v ac Class 1E instrument power system and operating configuration.

Fiche: $\quad$ 75147:313-75147:328

acn: $\quad 9306040271$ 
May 28, 1993

May 28, 1993

May 28, 1993

May 28, 1993

May 28, 1993

May 28, 1993

May 28, 1993

May 28, 1993

June 1, 1993

June 1, 1993
J. Fox, OB, letter forwarding markups to Chapter 8 material resulting from May 27, 1993, GE/NRC tolecon.

Ficho: 75137:330-75137:336

acn: $\quad 9306040231$

B. Simon, GE, letter forwarding proposed identification scheme regarding channel definitions for TS.

Fiche: 75278:342-75278:346

ecn: $\quad 9306080004$

D.J. Robare, GE, lotter forwarding Amendment 29 to ABWR SSAR. Changes in listed chapten primarily rosolution of draft final SER outstanding items.

Ficho: 75282:001-75285:083

acn: $\quad 9306080396$

C. Tang, GE, letter forwarding revised TS for LLO 3.10.11 regarding low power physics teet.

Fiche: 75300:304-75300:307

scn: $\quad 9306090177$

C. Tang, GE, letter forwarding revised TS page 3.10-32 clarifying what low power physics test LCO is intended to address. Phrase "partial SDM test required by RO 1.68," added per telecon.

Fiche: 75300:305-75300:305

ecn: $\quad 9306090204$

D.J. Robare, GE, letter forwarding proprietary sections of Chapters 3, 4, and 6 of ABWR SSAR, Amendment 29. Proprietary sections withheld.

Ficho: $\quad$ 75427:345-75427:347

ecn: $\quad 9306180143$

D.J. Robare, GE, letter forwarding proprietary drawings of Amendment 29 to ABWR SSAR. Drawings withheld.

Fiche: 75450:024-75450:025

acn: $\quad 9306180156$

D. Crutchfield, NRC, letter forwarding staff comments and questions regerding ABWR TS issues.

Fiche: $\quad 75261: 336-75261: 340$

acn: $\quad 9306070374$

C. Tang, GE, letter forwarding revised $18 \mathrm{~F}$ introduction for discussion.

Fiche: 75148:141-75148:142

acn: $\quad 9306040237$

J. Fox, GB, letter forwarding markups for Chapters 2 and 3 of ABWR SSAR regarding envelope of ABWR standard plant site design parameters and wind and tornado loadings. Fiche: 75139:014-75139:090

acn: $\quad 9306040240$ 
Appendix C

June 1, 1993

J. Fox, GE, letter forwarding SSAR markups to Chapter 8 material, resulting from May 28, 1993, GE/NRC telecon covering description of offsite power system, periodic testing of electrical system and equipment and Class $1 \mathrm{E}$ battery installation and maintenanace requirements.

Fiche: $\quad$ 75137:317-75137:329

acn: $\quad 9306040265$

June 1, 1993

June 1, 1993

J. Fox, GE, letter forwarding information for Appendix F of ABWR SSAR regarding containment liner plate evaluation for severe accident conditions. Supplement 1 to Bechtel Report RPT STRI-008, "Containment Structural Evaluation for Ultimate Pressure Capacity Rept," also enclosed.

Fiche: 75139:161-75139:257

acn: $\quad 9306040275$

C. Oza, GE, letter requesting response on acceptability of attached resolution for Open Item 19.1.6.4-3, with regard to personnel access and egress routes for fire suppression activities.

Fiche: $\quad$ 75794:346-75794:347

acn: $\quad 9307230173$

June 2, 1993

J. Fox, GE, letter forwarding information regarding important features identified by ABWR PRA, covering RCIC, combustion turbine generator, high pressure core flooder logic and control, ac independent water addition system and reactor building cooling water/reactor service water system.

Fiche: $\quad$ 75147:275-75147:312

acn: $\quad 9306040236$

June 2, $1993 \quad$ J. Fox, GE, letter forwarding markup of Chapter 9 of ABWR SSAR, per telecons with NRC. Subjects covered include tests and inspections (interface requirements), SE of equipment, and Table 9.2-41 regarding reactor building cooling water Division $A$.

Fiche: $\quad$ 75278:351-75278:361

acn: $\quad 9306080230$

June 2, 1993

J. Fox, GE, letter forwarding proprietary markup of Chapter 11 of ABWR SSAR, as result of telecons with NRC. Enclosure withheld.

Fiche: $\quad$ 75281:353-75281:353

acn: $\quad 9306080231$

June 2, 1993

J. Fox, GE, letter forwarding draft composite of Subsection 3.9.6 regarding design and qualification requirement for addition to page 3.9-22.

Fiche: $\quad$ 75304:294-75304:299

acn: $\quad 9306090264$

June 3, 1993

J. Baechler, GE, letter forwarding responses to questions raised by S. Ninit regarding radioactive drain transfer, DG combustion air intake and exhaust system and condensate and feedwater.

Fiche: $\quad 75279: 333-75279: 346$

acn: 9306090135

June 4, 1993

D.J. Robare, GE, letter forwarding revised versions of third phase of ABWR Tier 1/ITAAC material supporting accelerated ABWR design certification review.

Fiche: 75288:204-75288:324

acn: $\quad 9306090135$ 
June 4, 1993

June 4, 1993

June 7, 1993

June 9, 1993

June 10, 1993

June 11, 1993

June 11, 1993

June 11, 1993

June 14, 1993

June 14, 1993
J. Fox, GE, letter forwarding Attachments A, B, and C. Attechment A represents important insights from $A B W R$ severo accident analysis. Information will be used to develop Tier 2 documentation.

Fiche: 75305:242-75305:258

acn: $\quad 9306100160$

R.W. Borchardt, NRC, letter discussing resolution of two Open Items 4.4-1 and 20.3-8. GE should provide schedule for inputs for issues by June 9, 1993. Prompt response would allow staff opportunity to resolve open items in expeditious manner.

Fiche: 75315:346-75315:355

acn: $\quad 9306090142$

J. Fox, GB, letter forwarding draft amendment of ABWR SSAR Chapter 14, covering summary of test programs and objectives, const test objectives, preoperational test objectives and startup test objectives.

Fiche: 75324:001-75324:203

acn: $\quad 9306110073$

J. Fox, GE, letter forwarding draft, revised Appendix 18F consisting of results of analysis of information and control needs of main CR operators, to address draft FSER Confirmatory Item 18.4.3-1.

Fiche: 75384:003-75385:005

acn: $\quad 9306160050$

J. Fox, GE, letter forwarding set of draft I\&C TS, incorporating latest SSLC definitions into LCO 23.3.1.1. New LCO 3.3.1.4 regarding ECCS actuation will be developed by June 21, 1993, meeting.

Fiche: $\quad 75383: 012-75383: 012$

acn: $\quad 9306160060$

D.J. Robare, GE, letter providing licensee closure plan and status for resolution of questions on proprietary nature of certain portions of ABWR.

Fiche: 75368:298-75368:301

acn: $\quad 9306150425$

J. Fox, GE, letter forwarding revised responses to draft FSER Open Items 1.2.2-1 and 1.2.2-2. Vendor will submit final, verified SSAR, consisting of Tier 1 design description and complementary integrated set of ITAAC by July 31, 1993.

Fiche: 75384:001-75384:002

acn: $\quad 9306160047$

J. Fox, GE, letter forwarding revised TS LCO 3.6.4.3, "Standby Gas Treatment System." TS revised to address inoperability of both divisions of system.

Fiche: 75383:001-75383:260

acn: $\quad 9306160056$

J. Fox, GE, letter forwarding markup of SSAR Section 38 aligning with Appendix $3 \mathrm{H}$. Fiche: 75478:028-75478:035

acn: $\quad 9306240449$

J. Fox, GE, letter forwarding revised SSAR markup for DFSER COL Action Item 1.2.1-1, replacing licensee letter dated April 30, 1993, for item.

Fiche: 765478:036-75478:038

acn: $\quad 9306240453$ 


\section{Appendix $\mathbf{C}$}

June 14, 1993

June 14, 1993

June 14, 1993

June 15, 1993

June 15, 1993

June 16, 1993

June 16, 1993

June 17, 1993

June 18, 1993

June 18, 1993
J. Fox, GB, letter forwarding SSAR markup addressing DFSER Open Item 2.6-1, providing supplemental information to April 16, 1993, letter.

Fiche: 75506:343-75506:345

acn: $\quad 9306240459$

J. Fox, GE, letter forwarding proprietary markups of SSAR Appendix 3C, reflecting FINEL code and Appendix 19F, mainly incorporates liner tearing.

Ficho: 75493:269-75493:274

acn: $\quad 9306280311$

J. Fox, GE, letter forwarding SSAR markup, replacing markup in April 28, 1993, letter addreseing draft FSER Open Item 1.2.6-1.

Fiche: $\quad 75514: 175-75514: 183$

acn: $\quad 9306280311$

J. Fox, GE, letter forwarding SSAR markup of Figure 1.2-1, replecing figure provided in June 14, 1993, letter, addreasing DFSER Open Item 1.2.6-1.

Fiche: $\quad 75512: 350-75512: 351$

acn: $\quad 9306280224$

J. Fox, GE, letter forwarding SSAR markup of Appendix 18E plus attachment to Table 18E.2.1, GE belioves provides satisfactory resolution of DFSER Open Item 18.9.2.2.11.

Fiche: 75514:163-75514:174

scn: $\quad 9306280228$

C.I. Grimes, NRC, letter forwarding preliminary drafts of low power and shutdown TS proposed for BWR current designs.

Fiche: $\quad 76075: 001-76076: 156$

acn: $\quad 9308110177$

C.I. Grimes, NRC, letter forwarding preliminary draft BWR STS for lower power and shutdown conditions.

Fiche: 76063:356-76063:360

acn: $\quad 9308110259$

C.L. Larson, GE, letter forwarding revised sections of 19K.5 anf 19K.11.7 for ABWR SSAR. Sections reflect changes in PRA input to RAP regarding seismic analysis.

Fiche: $\quad$ 75794:348-75794:351

acn: $\quad 9307230190$

J. Fox, GE, letter forwarding markup of draft SSAR Subsection 18.8 on GE/NRC Muy 27, 1993, telecon.

Fiche: $\quad$ 75501:329-75501:331

acn: $\quad 9306240359$

J. Fox, GE, letter forwarding SSAR markup addressing suppression pool strainer Issue 42. Information will be included in Amendment 30 scheduled for transmittal to NRC on July 8, 1993.

Fiche: $\quad 75506: 350-75506: 358$.

acn: $\quad 9306240426$ 
June 18, 1993

June 18, 1993

June 18, 1993

June 21, 1993

June 22, 1993

June 22, 1993

June 23, 1993

June 23, 1993

June 23, 1993
D.J. Robare, GE, letter forwarding revised "ABWR Design Document." Material represents fourth and lest of ABWR Tier 1/ITAAC submittal scheduled. Transmittal, together with transmittals of April 26, May 21, and June 4, 1993, provides material for total of 79 ABWR systems.

Fiche: 75504:242-75504:359

acn: $\quad 9306240454$

J. Fox, GE, letter forwarding responses to NRC comments on startup test material dated June 7, 1993, and pro-operational test material dated June 14, 1993.

Fiche: 75501:338-75501:342

ecn: $\quad 9306240456$

J. Fox, GE, letter forwarding results of analyses assuming postulated common mode failure of SSLC and analyses assuming coincident failure of feedwater control system.

Ficho: 75511:150-75511:202

scn: $\quad 9306280337$

N. Hackford, GE, letter forwarding revision to June 18, 1993, submitta regarding fourth phase of revised ABWR Tier 1/ITAAC material.

Fiche: $\quad$ 75509:339-75509:341

acn: $\quad 9306280197$

J. Fox, GE, letter forwarding SSAR markups to Chapter 8 materials resulting from GB/NRC June 21, 1993, conference addressing listed confirmatory items. With exception of Appendix 1C (station blackout), responses should close out all remaining Chapter 8 outstanding items.

Fiche: $\quad$ 75512:330-75512:344

acn: $\quad 9306280235$

J. Fox, GE, letter forwarding SSAR markup addressing Items 20, 27, and 31 of June 7 through 10, 1993, meeting in San Jose regarding containment overpressure protection system.

Fiche: 75509:178-75509:208

acn: $\quad 9306280244$

J. Fox, GE, letter forwarding modification to paper entitied, "Impertant Features Identified by ABWR PRA," submitted on June 2, 1993.

Fiche: $\quad$ 75521:259-75521:297

acn: $\quad 9306290049$

J. Fox, GE, letter forwarding SSAR markups resulting from GE/NRC June 23, 1993, Plant Systems Branch telecon, including Chapters 6, 9, and 11.

Fiche: 75527:348-75527:360

acn: $\quad 9306290078$

B. Raftery, GE, letter responding to NRC questions regarding generation of minimal cut sets in performing ABWR fire risk analysis and justification for why GE did not use important measures to analyze features from standpoint of fire risk.

Fiche: $\quad$ 75794:345-75794:345

acn: $\quad 9307230135$ 
Appendix C

June 24, 1993

J Fox, GE, letter forwarding markups reflecting minor mods resulting from NRC review and internal verification of SSAR Sections 19.7 through 19.13. Material will be reflected in Amendment 31.

Fiche: $\quad$ 75522:212-75522:243

acn: $\quad 9306300044$

June 24, 1993

June 24, 1993

J. Fox, GE, letter forwarding SSAR markup os Subsection 9.4.6 regarding radwaste building ac system, omitted from June 23, 1993, letter.

Fiche: $\quad$ 75522:343-75522:345

acn: $\quad 9306300046$

J. Fox, GE, letter forwarding markups addressing RPV water level instrumentation, Issue No. 15. Material will be included in Amendment 30 scheduled for transmittal to NRC on July 8, 1993.

Fiche: 75543:230-75543:244

acn: $\quad 9306300163$

June 24, 1993

A. McSherry, GE, letter forwarding final control building flooding event tree, noting that anti-siphon capability part of design of RSW system on both supply and return lines.

Fiche: $\quad 75794: 343-74794: 344$

acn: $\quad 9307230120$

June 25, 1993

D. Crutchfield, NRC, letter forwarding chart of milestones to develop ABWR TS as discussed during managenent meeting on June 10, 1993.

Fiche: $\quad$ 75525:078-755:25:084

acn: $\quad 9306300236$

June 28, 1993

J. Fox, GE, letter forwarding revised response to structural audit Item 11 of May 7, 1993, letter and markups of associated SSAR Sections 3.7 and 3A.

Fiche: 75683:183-75683:233

acn: $\quad 9307150133$

June 28, 1993

J. Fox, GE, letter forwarding SSAR markups responding to NRC request to provide oscillation power range monitor (OPRM) for ABWR. Design is BWROG LPRM based OPRM (Option III applicable to ABWR).

Fiche: $\quad 75684: 281-75684: 316$

acn: $\quad 9307150170$

June 28, 1993

J. Fox, GE, letter forwarding final draft Section 19D.10, data uncertainty analysis for ABWR. Section will be included in Amendment 30 scheduled for issuance on July 8 , 1993.

Fiche: $\quad 75684: 258-75684: 278$

acn: $\quad 9307150173$

June 28, 1993

J. Fox, GE, letter forwarding SSAR markups addressing Suppressing Bypass Issue 24, including Saction 6.2.1, containment functional design, Appendix 18A, emergency procedure guidelines and Appendix 18B, difference between BWROG EPG Revision 4 and ABWR EPG.

Fiche: 74582:088-75682:114 
Jun: 29,1993

June 29, 1993

June 29, 1993

June 29, 1993

June 30, 1993

July 2, 1993

July 2, 1993

July 2, 1993

July 2, 1993
R.C. Mitchell, GE, letter forwarding ABWR Tier 1/ITAAC material that was not included in submittals dated April 26, May 21, June 14 and 18, 1993. Material preliminary in that material has not been fully verified using GE procedures governing compliance with QA requirements.

Fiche: $\quad$ 75596:216-75596:278

acn: $\quad 9307060125$

J. Fox, GE, letter forwarding revisions to Section 5.0 of TS, previously submitted per discussions with NRC regarding main control room staffing.

Fiche: $\quad 75683: 325-75683: 327$

acn: $\quad 9307150114$

D. Crutchfield, NRC, letter forwarding proof and review ABWR TS and bases for sections listed.

Fiche: $\quad 75564: 312-75564: 346$

acn: $\quad 9307020288$

R.W. Borchardt, NRC, letter forwarding comments regarding NRC review of ITAAC and NRC responses to GE June 4 and 22, 1993, letters. GE should revise ITAAC to resolve comments.

Fiche: 75564:347-75564:354

acn: $\quad 9307020326$

J. Fox, GE, letter forwarding proposed TS regarding shutdown, addressing Issue 16 for ABWR.

Fiche: $\quad 75686: 266-75686: 283$

acn: $\quad 9307160082$

J. Fox, GE, letter forwarding writeups for GSI 73, 113, 120, and 151 regarding detached thermal sleeve, dynamic qualification testing of large bore hydraulic snubbers, online testability of protectionsystem and reliability of ATWS recirculation pump trips, respectively.

Fiche: $\quad$ 75683:281-75683:285

acn: $\quad 9307150083$

J. Fox, GE, letter forwarding SSAR markups of emergency procedures guidelines, incorporating ATWS stability strateg (Issue 12), per NRC request during June 10, 1993, meeting.

Fiche: $\quad$ 75683:286-75683:294

acn: $\quad 9307150092$

J. Fox, GE, letter forwarding responses to NRC June 28, 1993, comments on Chapter 14. Responses, where applicable, will be included in Amendment 30 scheduled for transmittal on July 8, 1993.

Fiche: $\quad 75683: 295-75683: 298$

acn: $\quad 9307150167$

J. Fox, GE, letter forwarding final version of Appendix 1C ABWR station blackout considerations, replacing draft version of appendix provided in letter dated April 30, 1993, and addressing DFSER Confirmatory Item 9.2.13-1.

Fiche: $\quad 75700: 155-75700: 226$

acn: $\quad 9307160297$ 
Appendix C

July 2, 1993

July 2, 1993

July 7, 1993

July 7, 1993

July 7, 1993

July 8, 1993

July 8, 1993

July 8, 1993

July 8, 1993

July 8, 1993

D. Crutchfield, NRC, letter forwarding proof and roviow ABWR TS and bases for listed sections.

Fiche: 75650:262-75650:339

acn: $\quad 9307140187$

D. Crutchfield, NRC, letter forwarding proof and review ABWR TS and their bases for Sections 3.1, "Reactivity Control," and 3.2, "Power Distribution."

Fiche: 75674:227-75674:304

acn: $\quad 9307150054$

J. Fox, GE, letter forwarding documentation of special LOCA core cooling analysis, performed to support TS extended AOTs.

'Fiche: 75683:343-75683:354

acn: $\quad 9307150076$

J. Fox, GE, letter forwarding information regarding ABWR reactor water lovel system capabilities and indications of inadequate RPV water level, independent of RPV water level instrumentation.

Fiche: 75685:096-75685:103

acn: $\quad 9307150127$

C. Poslusny, NRC, letter informing that NRC voted to exempt ABB-CE System 80+ design certification from NRC policy on metrication and requests that licensee state whether or not to be relieved of responsibility for performing conversions.

Fiche: 75611:148-75611:149

acn: $\quad 9307090238$

D.J. Robare, GE, letter forwarding Amendment 30 to Revision C to "Advanced BWR SSAR." Changes are resolution DFSER outstanding items.

Fiche: 75663:001-75670:052

acn: $\quad 9307130190$

D.J. Robare, GE, letter forwarding proprietary Amendment 30, Revision B to GE ABWR SSAR.

Fiche: $\quad$ 75661:345-75661:346

acn: $\quad 9307130196$

J. Fox, GE, letter forwarding updated safety issues index incorporating NRC June 24, 1993, comments.

Fiche: $\quad 75795: 342-75795: 347$

acn: $\quad 93072230220$

D.J. Robare, GE, letter forwarding Amendment 30 to proprietary foldout drawings to GE ABWR SSAR Chapter 7, "Instrumentation \& Control Systems," revising Section 7.2, 7.3, and 7.7.

Fiche: $\quad 75985: 343-75985: 343$

acn: $\quad 9307270041$

D.J. Robare, GE, letter forwarding Amendment 30, non-proprietary foldout drawings to GE ABWR SSAR, for Sections 3H, 4.6, 5.1, 5.4, 6.2, 6.7, 9.1, 9.3, 9.5, and 20.3.

Fiche: 75941:001-75941:134

acn: $\quad 9307270096$ 
July 9, 1993

July 9, 1993

July 9, 1993

July 12, 1993

July 12,1993

July 15,1993

July 15, 1993

July 15,1993

July 15, 1993

J. Fox, GE, letter forwarding electrical shutdown TS LCOs 3.8.2, 3.8.Y, 3.8.5, 3.8.8, and 3.8.10. Bases for listed LCOs, accordingly. TS cover ac sources - shutdown and de sources - shutdown and refuoling.

Fiche: 75676:267-75676:283

acn: $\quad 9307140244$

J. Fox, GE, letter forwarding SSAR markup resolving ISLOCA Issue 42 regarding intersystem LOCA for ABWR, replacing text in author April 30, 1993, letter.

Fiche: $\quad$ 75684:169-75684:236

ecn: $\quad 9307150079$

R.W. Borchandt, NRC, letter forwarding staff comments on GE ABWR Tier 1 submittals dated April 26, May 21, June 4, 18, 21, and 29, 1993. Advises that GE should revise Tier 1 design certification material to resolve comments and provide markup immediately.

Fiche: 75680:001-75680:169

acn: $\quad 9307160282$

J. Fox, GE, letter forwarding SSAR markups providing design portion of resolution of I\&C Diversity Issue 46, including Appendices 7C and 7B. Analysis portion of issue provided in June 18, 1993, letter.

Fiche: $\quad 75685: 131-75685: 184$

acn: $\quad 9307160046$

J. Fox, GE, letter fonwarding proprietary data of 10 and 9 RIP operations. Data withheld.

Fiche: $\quad$ 75728:358-75728:358

acn: $\quad 9307200231$

J. Fox, GE, letter forwarding bases for shutdown TS LCOs 3.7.2 regarding reactor building cooling water system, reactor service water system \& UHS - shutdown and 3.73 regarding reactor building cooling water system, reactor service water system \& UHS refueling.

Fiche: 75723:169-75723:194

acn: $\quad 9307200286$

J. Fox, GE, letter forwarding responses to NRC comments on USIs/GSIs, including July 9, 1993, telecon and addition of Issue C-8 to issue group resolved with no new requirements.

Fiche: $\quad 75726: 301-75726: 315$

acn: $\quad 9307210122$

J. Fox, GE, letter forwarding SSAR markup, clarifying in/out scope portion of potable and sanitary water system, requested in ITAAC questions and during July 14, 1993, telocon. Change will be included in Amendment 32, scheduled for submittal on August 31, 1993.

Fiche: $\quad 75726: 334-75726: 340$

acn: $\quad 9307210125$

D. Crutchfield, NRC, letter forwarding proof and review ABWR TS and bases for listed sections.

Fiche: 76038:215-76038:313

acn: $\quad 9308100219$ 
Appendix C

July 16, 1993

July 20,1993

July 21,1993

J. Fox, GE, letter forwarding SSAR markup, clarifying boundaries of nonradioactive drain system, radioactive drain transfer system and liquid radwaste system.

Fiche: $\quad$ 75795:335-75795:341

acn: $\quad 9307230215$

J. Fox, GE, letter forwarding SSAR markups for listed changes made as result of consistency check between PRA and EPGs (Issue 9).

Fiche: 75930:271-75930:296

acn: $\quad 9307290049$

J. Fox, GE, letter informing that operator action histories for three different postulated LOCAS, previously evaluated in GE June 18, 1993, letter, requiring operator action within twenty minutes developed to close out operator time line aspect.

Fiche: 76022:155-76022:159

acn: $\quad 9308050197$

July 21,1993

J. Fox, GE, letter forwarding shutdown electrical TS 3.8.2, 3.8.5, 3.8.8, and 3.8.10 and associated bases.

Fiche: $\quad$ 76022:304-76022:334

acn: $\quad 9308050199$

July 21, 1993

J.N. Wilson, NRC, letter forwarding draft safety issues index, generic issue review assignments, status of ABWR USI-GSI review and staff comments provided during conference calls.

Fiche: $\quad 76075: 164-76075: 184$

acn: $\quad 9308120019$

July 23, 1993

D. Crutchfield, NRC, letter forwarding proof and review ABWR TS and bases for Sections 3.4, RCS, 3.5, ECCS and 5.0 Administrative Controls (No Bases).

Fiche: $\quad$ 76104:057-76104:208

acn: $\quad 9308160300$

July 26, 1993

J. Fox, GE, letter forwarding listed items addressing M. Malloy July 2, 1993, fax regarding USIs and GSIs, with regard to accelerated ABWR review.

Fiche: 75997:027-75997:055

acn: $\quad 9308040120$

July 26,1993

C. Poslusny, NRC, letter forwarding comments identifying items which need to be addressed in August SSAR amendment and documents generated by PRA task force.

Fiche: 75907:310-75907:334

acn: $\quad 9307280196$

July 27, 1993

J. Fox, GE, letter forwarding tabulation documents results of sensitivity analyses performed to determine impace of removal of ESF equipment from service.

Fiche: $\quad$ 75979:355-75979:358

acn: $\quad 9308030191$

July 28, 1993

R.C. Mitchell, GE, letter forwarding Revision 1 to 23A6100, "ABWR SSAR," Chapters 1 through 21. Listed sections contain proprietary information and will be submitted under separate cover.

Fiche: 76040:001-76056:011

acn: $\quad 9308040020$ 
July 28, 1993

July 28, 1993

July 30, 1993

July 30, 1993

August 3, 1993

August 4, 1993

August 4, 1993

August 6, 1993

August 6, 1993

August 6, 1993
R.C. Mitchell, GE, letter forwarding proprietary Revision 1 to 23A6100, "ABWR SSAR," Chapters 19 and 20 w/600 oversize drawings.

Fiche: 75998:001-75998:001

acn: $\quad 9308040057$

J. Fox, GE, letter forwarding revised shutdown TS LCO 3.8.Y and associated bases.

Fiche: 76037:216-76037:228

acn: $\quad 9308090329$

J. Fox, GE, letter responding to July 28,1993 , letter regarding staff review of licensee July 9, 1993, ISLOCA letter.

Fiche: 76011:005-76011:008

acn: $\quad 9308040327$

D. Crutchfield, NRC, letter forwarding proof and review ABWR TS for listed sections. Information in preparation for August 19 and 20, 1993, meeting also enclosed.

Fiche: $\quad$ 76286:001-76286:246

acn: $\quad 9309010196$

J. Fox, GE, letter forwarding SSAR markups addressing Generic Fuel Licensing Item 17 and proprietary Appendix 4D, demonstrating that Chapters 4 and 15 meet proprietary acceptance criteria of Appendix 4B. Vendor plan to include information in Amendment 32 due by August 31, 1993. Appendix 4D withheld.

Fiche: 76080:234-76080:235

acn: $\quad 9308110367$

J. Fox, GE, letter forwarding SSAR markup addressing fuel bundle mis-orientation Item 4. Informs that GE plan to include information in Amendment 32 scheduled to be transmitted to NRC on August 31, 1993.

Fiche: 76075:343-76075:352

acn: $\quad 9308110247$

J. Fox, GE, letter forwarding updated TS sensitivity runs, as result of error discovered in modeling made to assess impact on CDF resulting from removal of ESF equipment from service, per July 27,1993 , transmittal.

Fiche: $\quad 76077: 326-76077: 327$

acn: $\quad 9308110252$

J. Fox, GE, letter forwarding background and GE respones to Equipment/Instrumentation Survivability Iseue 29. Concludes that SSAR adequately addresses issue and no further consideration of issue required.

Fiche: $\quad 76082: 325-76082: 326$

acn: $\quad 9308110376$

J. Fox, GE, letter forwarding new SSAR Section 3H.5, structural analysis reports.

Section will be included in Amendment 32 scheduled for transmittal on August 31, 1993

Fiche: $\quad$ 76077:264-76077:268

acn: $\quad 9308110380$

J. Fox, GE, letter forwarding draft analysis demonstrating that containment pressure can be controlled by venting early in sequence preventing pressure increasing to high drywell pressure containment isolation setpoint.

Fiche: $\quad 76076: 310-76076: 322$

acn: $\quad 9308110388$ 
Appendix C

August 6, 1993

August 6, 1993

August 10, 1993

August 10, 1993

August 12, 1993

August 17, 1993

August 17, 1993

August 18, 1993

August 18, 1993

August 18, 1993
C.K. Tang, GE, lotter forwarding revised TS 3.5.1, ECCS-operating. TS is LCO 3.5.1 for proviously transmittod beses for TS 3.5.1.

Fiche: 76082:316-76082:324

scn: $\quad 9308110394$

C.K. Tang, GE, letter forwarding revised LCO 3.5.1 and bases, based on LOCA analyses requested by $\mathrm{G}$. Thomes and PRA analyses requested by M. Wohl and BNL. Fiche: 76076:287-76076:309

scn: $\quad 9308110397$

D. Crutchfield, NRC, letter forwarding proof and roviow of ABWR TS and bases for Sections 3.6, "Containment Systems," and 3.7, "Plant Systems."

Ficho: 76248:006-76248:189

scn: $\quad 9308270317$

D. Crutchfield, NRC, lottor forwarding proof and roview of ABWR TS and bases for Soctions 3.6, "Containment Systems," and 3.7, "Plant Systems." Informs that soctions as provided acceptable.

Fiche: 76411:001-76411:185

acn: $\quad 9309090466$

R.W. Borchardt, NRC, letter providing staff reviow comments on GIs regarding ABWR design. Advises that GE has not sufficiently addressed, in revised SSAR markups, all comments and concerns proviously provided by staff.

Fiche: 76220:241-76220:255

scn: $\quad 9308270195$

G. Kelly, NRC, letter forwarding comparative markup of insights list showing differences between July 23, 1993, version and August 10, 1993, version.

Fiche: $\quad$ 76247:317-76247:335

acn: $\quad 9308260325$

D. Crutchfield, NRC, letter forwarding proof and review advanced BWR TS for low power and shutdown. Anticipates that formal comments to proof and review advanced BWR TS will be made by September 20, 1993.

Fiche: 76306:144-76305:283

acn: $\quad 9309020176$

J. Fox, GE, letter forwarding drafts of revised Sections 11.2, 11.3, 11.4, and associatod drawings that will be incorporated in Amendment 32 as non-proprietary. Proprietary versions of 11.2, 11.3, and 11.4 will be retained in GE design record files w/16 figures. Fiche: $\quad 76183: 299-76183: 345$

acn: $\quad 9308190180$

J. Fox, GE, letter forwarding final SSAR markup of changes to Appendix 18E. Changes will be included in Amendment 32 to ABWR.

Fiche: $\quad 76236: 273-76236: 288$

acn: $\quad 9308260305$

J. Fox, GE, letter forwarding Subsection 13.5, "Plant Procedures." Section will be included in Amendment 32 to ABWR.

Fiche: $\quad 76258: 355-76258: 360$

acn: $\quad 9308260312$ 
Auguat 18, 1993

Auguat 19, 1993

August 20, 1993

Auguat 23, 1993

August 23, 1993

August 25, 1993

August 26, 1993

August 26, 1993

August 27, 1993
R.W. Borchardt, NRC, letter requeating that corrected pages enclosed be used to replace pages inadvertently included in staff roview comments on generic iesues regarding ABWR.

Ficho: 76285:307-76285:310

acn: $\quad 9309010226$

J. Fox, GE, letter forwarding propoeed SSAR markup adopting NRC position on Appendix B to ACI349.

Fiche: 76237:239-76237:244

acn: $\quad 9308260352$

M.J. La Rue, GE, lettor providing edvance notice of export shipment of SNM of low strategic significance (Category III).

Fiche: $\quad 71837: 289-71827: 290$

ecn: $\quad 9309080103$

J. Fox, GE, lotter forwarding SSAR markup providing resolution of several severe accident issues raised by NRC. Markup will be included in next amendment for corresponding chapters of ABWR.

Fiche: $\quad$ 76236:289-76236:320

acn: $\quad 9308260296$

J. Duncan, GE, letter forwarding ABWR PRA/SA/DBA punch list, per August 12, 1993, telecon.

Fiche: $\quad 76283: 223-76283: 237$

scn: $\quad 9308260341$

J.N. Fox, GE, letter forwarding proposed addition to SSAR Chapter 19 addressing issue of design certification material report contents, reflecting GE understanding of disposition of roed map issues discussed during GE/NRC meetings July 27 through 29, 1993, in San Jose.

Fiche: 76304:209-76304:264

acn: $\quad 9308310085$

J.F. Quirk, GE, letter forwarding GENE-A0003649-01 "Technical Support Document for Amends to 10 CFR 51 Considering Severe Accidents Under NEPA for Plants of ABWR Design," per SRM dated October 25, 1991, regarding SECY-91-229, "Sovere Accident Mitigation Design....".

Fiche: $\quad 76316: 247-76316: 278$

acn: $\quad 9309010088$

D. Crutchfield, NRC, letter responding to several informal inquiries from design certification applicants regarding form and content of design control document.

Forwarding current staff views regarding document.

Fiche: 76396:143-76396:151

acn: $\quad 9309100237$

J.F. Quirk, GE, letter requests that NRC exempt ABWR design certification from compliance with requirements of metrication policy adopted last year by NRC and published in FR (57FR46202), dated October 7, 1992, in reference to NRC July 7, 1993, letter.

Fiche: $\quad 76344: 314-76344: 315$

acn: $\quad 9309020374$ 
Appendix C

Auguat 30, 1993

J. Fox, GB, letter forwarding TS Section 3.3, "Instrumentation," for proof and reviow.

Ficho: 76342:001-76342:293

scn: $\quad 9309020032$

Auguet 30, 1993

R.W. Borchardt, NRC, letter requesting staff support to complete scope of inspection to be conducted at facility in San Jose, California on September 7 through 10, 1993.

Inspection to review QA programs.

Fiche: 76396:140-76396:142

ecn: $\quad 9309100256$

August 31, 1993

J.F. Quirk, GB, letter forwarding Volumes 1 and 2 of "ABWR Certified Design

Material." $\mathrm{GB}$ believes that submittal represents complete set of Tier 1 ABWR material noceseary to support design certification of ABWR, per 10 CFR Part 52.

Fiche: 76343:001-76344:286

acn: $\quad 9309020393$

Auqust 31, 1993

September 1, 1993

September 1, 1993

September 2, 1993

September 2, 1993

September 2, 1993

September 10, 1993
D. Crutchfield, NRC, letter forwarding proof and review ABWR TS and bases for Sections 3.3, "Instrumentations" and 3.8, "Electric Power (includes Low Power \& Shutdown)."

Fiche: 76432:001-76433:121

acn: $\quad 9309140171$

J. Fox, GE, letter,forwarding new SSAR Subsection 3H.5.5, "Structural Analysis Report for Turbine Building."

Ficho: 76369:335-76369:336

acn: $\quad 9309030344$

J. Fox, GE, letter forwarding revised markups for Issues A10, A17, A47, B5, C8, C17, $25,51,82,89,113,143,153$, and revised index (Table 19B.1-1) in response to NRC August 4, 1993, comments for review and resolution.

Fiche: 76372:312-76372:339

ecn: $\quad 9309070196$

J. Fox, GE, letter forwarding August 31, 1993, letter from Bechtel, documenting that civil/structural calculations for licensing support of ABWR project performed, per Bechtel QA project procedures manual.

Fiche: 76409:357-76409:358

scn: $\quad 9309080222$

'J. Fox, GE, letter forwarding missing pages from ABWR TS Section 3.3 proof and reviow version sent on August 30, 1993.

Fiche: 76397:231-76397:245

acn: $\quad 9309080237$

J. Fox, GE, letter forwarding Chandra September 2, 1993, note on Subsection 9.4.

Fiche: $\quad 71850: 146-71850: 147$

acn: $\quad 9309080358$

C.K. Tang, GE, letter forwarding advanced page of Amendment 32 on Revision 1A.2.34. List of system expanded to include system that perform containment atmosphere and reactor coolant sampling functions, per September 9, 1993, telecon request.

Fiche: 76449:351-76449:352

scn: $\quad 9309150192$ 
Septombor 10, 1993

September 13, 1993

Septomber 13, 1993

September 13, 1993

September 13, 1993

September 15, 1993

September 15, 1993

September 17, 1993

September 17, 1993

September 17, 1993
J. Fox, OE, lotter forwarding Bechtel September 10 and Auguat 31, 1993, lettern regarding QA program plan and ABWR licensing aupport, civil/atructural calculationa, respectively.

Fiche: 76449:353-76449:355

ecn: $\quad 9309150199$

J. Fox, OE, letter forwarding markups of P\&R vervion of TS Section 1.1, "Definitions." Fiche: $\quad$ 76512:037-76512:048

acn: $\quad 9309210164$

J. Fox, GE, lotter forwarding P\&R version of TS Sections 2.0, 3.0, and 3.1 aupporting accelernted ABWR roviow schedule.

Ficho: 76511:324-76511:338

acn: $\quad 9309210182$

J. Fox, GE, letter forwarding marked up TS on LCO 3.5.2 regarding BCCS shutdown.

Ficho: $\quad$ 76511:334-76511:352

acn: $\quad 9309210207$

J. Fox, GE, letter forwarding TS supporting accelorated ABWR schedulo regarding containment electrical penetration assemblies.

Fiche: 76511:339-76511:341

acn: $\quad 9309210211$

J. Fox, GE, letter forwarding two letters from Bechtel documenting application of QA project procedures manual to advanced BWR certification program.

Fiche: $\quad 76590: 358-76590: 360$

acn: $\quad 9309280277$

J. Fox, GE, letter forwarding revised P\&R version of TS LCOs 3.5.1 and 3.7.1 and associated beses to replace LCOs 3.5.1 and 3.7.1 issued for P\&R dated July 22, and 30, 1993, respectively.

Fiche: 76511:170-76511:206

acn: $\quad 9309210202$

J.F. Quirk, GE, letter forwarding Amendment 32 to nonproprietary portions of "ABWR SSAR," transmitting final information required for NRC to completo roview of ABWR and information resulting from GE internal SSAR verification process w/nonproprietary oversize drawings Books 1 and 2.

Fiche: 76530:001-76543:152

acn: $\quad 9309210131$

J.F. Quirk, GE, letter forwarding Amendment 32 to proprietary Sections 1.3 and 6.3, Appendices 3B, 4B, 4C, 4D, and 20A of "ABWR SSAR" w/proprietary oversize drawings. Proprietary section, appendices, and drawings withhold.

Fiche: 76515:337-76515:338

acn: $\quad 9309210147$

J. Fox, GE, letter forwarding P\&R markups of TS Section 3., "Containment Syatoms," with exception of LCO 3.6.2.4, "Wetwell Spray," ard associatod bases. Markups of LCO 3.6.2.4 and bases will be provided on Septomber 21, 1993.

Fiche: 76589:001-76589:128

acn: $\quad 9309280003$ 


\section{Appendix C}

September 17, 1993

September 17, 1993

September 17, 1993

Septomber 20, 1993

September 21, 1993

September 21, 1993

Soptember 21, 1993

September 23, 1993

September 27, 1993

September 28, 1993
J. Fox, OB, letter forwarding PQR markupe of TS Section 3.7, "Plant Syatem,," apporting accolernted advanced BWR echedule.

Fiche: 76591:208-76591:311

scn: $\quad 9309280005$

J. Fox, OB, letter forwanding report of September 10, 1993, tolecon regarding acoumption of no superheat in SSAR corium ahiold analyeis.

Ficho: $\quad 76590: 306-76590: 310$

ecn: $\quad 9309280275$

J. Fox, OB, letter forwanding Ameadment 32 to edvanced BWR SSAR Subeections 6.2.5.2.6.1(6) and 19B.2.1.2.3 which close out punch liat Items 31 and 29, reepectivaly.

Ficho: 76591:315-76591:322

scn: $\quad 9309280279$

J. Fox, OB, letter forwarding marked up TS Section 5.0, "Administrative Controls." Submection 5.7.2.13, "Exploaive Ges and Storage Radioactivity Monitoring Program," should be doloted duo to inapplicability to advanced BWRs.

Ficho: 76582:252-76582:261

scn: $\quad 9309280001$

J. Fox, GE, lotter forwarding markups of TS LCO 3.6.2.4, "RHR Wotwell Spray" and hesociated besees.

Fiche: $\quad 76588: 333-76588: 340$

scn: $\quad 9309280009$

J. Fox, GE, lotter forwanding markup of TS Section 1.1, "Definitions," supporting accelerated advanced BWR schedule.

Fiche: $\quad$ 76588:307-76588:312

acn: $\quad 9309280011$

J. Fox, GE, letter forwarding marked up TS Section 3.3, "Instrumentation," in support of accelerated advanced BWR reviow schedule.

Fiche: $\quad$ 76592:001-76592:308

acn: $\quad 9309280282$

J. Fox, GE, letter forwarding markups on TS Section 3.8, "Electrical Systems," supporting accelerated advanced BWR review schedule.

Fiche: 76588:271-76588:306

acn: $\quad 9309280007$

T.H. Boyco, NRC, letter mubmitting initial staff comments on OE ABWR Tier 1 Aurut 31, 1993, submittal regarding ABWR cortified design material. Submittal adoquately reflects agreements reached for Tier 1 material.

Fiche: 76673:202-76673:225

acn: $\quad 9310060058$

W.H. Rasin, NUMARC, letter providing comments on draft guidance on form and content of design control document.

Fiche: $\quad 71886: 002-71886: 026$

scn: $\quad 9310070374$ 
September 29, 1993

September 30, 1993

September 30, 1993

October 1, 1993

October 4, 1993

October 4, 1993

October 5, 1993

October 5, 1993

October 8, 1993
J. Fox, OB, letwer forwarding markups for Table 3.9-8, "IST" of ABWR SSAR.

Ficho: 76709:302-76709:316

sco: $\quad 9310050359$

J. Fox, GE, letter forwarding SSAR markup that removes doviation from Section B.3.a of Appendix A to Section 6.2.1.1.C of SRP reganding povition indicatore and alarme for vecuum breakers and amplifice vacuum valve operability toets, as follow-up to September 28, 1993, selecon.

Fiche: 76726:161-76726:166

sen: $\quad 9310070150$

J.F. Quirk, OB, letter forwarding "ABWR SSAR/Tier 1 Croses Roference Material," consinting of tables which identify rolationship between SSAR anfoty analyeis ancumptions and ITAAC defined in ABWR deaign cortification matorial submittod in Auguet 31, 1993, letter.

Ficho: 76728:271-76728:329

ecn: $\quad 9310080166$

J. Fox, GE, letter forwarding markup on TS LCO 3.5.1, "BCCS-Operating,"

incorporating roviow comments discusced between GE and NRC on September 30, 1993, in San Jose. Condition $H$ also broken into now Conditions $E$ and $F$, as agreed during reference meoting.

Fiche: 76700:311-76700:336

scn: $\quad 9310060289$

J. Fox, OB, lottor forwarding SSAR markup of Section 11.5, providing COL licenso information and extended range offluent monitors for post accident monitoring, por TMI Itom II.F.1.

Fiche: 76725:339-76725:344

ecn: $\quad 9310080066$

J. Fox, OE, letter forwarding TS LCO 3.8.1, "AC Sources-Operating," incorporating roviow comments discuseed between GB and NRC on September 30, 1993, in San Jose and now condition to addrous inoperability of ono unit auxiliary transformer.

Ficho: $\quad$ 76717:210-76717:272

acn: $\quad 9310080072$

J. Fox, GE, letter forwarding SSAR markups covering classification of spent fuel pool line, appropriato figure for crack leak rato and inlet temperature protection for fuel pool cooling system filtor demineralizers.

Fiche: 76765:271-76765:274

ecn: $\quad 9310130279$

J. Fox, GE, letter forwarding TS LCO 3.3.4 ATWS and EOC-RPT Figure 3.3.4-1 for bases to be included in Revision $O$ of TS.

Ficho: 76802:222-75802:223

scn: $\quad 9310150119$

J. Fox, GE, letter forwarding ABWR schedule regarding fuel and core designs.

Fiche: 76802:173-76802:174

ecn: $\quad 9310150283$ 
Appendix C

October 8, 1993

October 13, 1993

October 13, 1993

October 13, 1993

October 13, 1993

October 18, 1993

October 20, 1993

October 20, 1993

October 20, 1993

October 22, 1993
J. Fox, GE, letter forwarding ABWR schedule regarding EPG changes incorporating ATWS atability issues.

Fiche: $\quad 76802: 275-76802: 280$

acn: 9310150285

J. Fox, GE, letter forwarding ABWR SSAR Appendix 19A markups.

Fịche: 76837:299-76837:308

san: $\quad 9310190108$

J. Fox, GE, letter forwarding SSAR markup of selected portions of Section 6.5 which addresess discussion items of GE/NRC Plant Systoms Branch October 13, 1993, telecon. Fiche: 76837:311-76837:319

ecn: 9310190111

J. Fox, GE, letter forwarding deecription of basis for drywell spray initiation limit for $A B W R$, in response to $M$. Snodderly request in connection with review of containment EPGs.

Fiche: 76892:190-76892:196

acn: $\quad 9310210300$

J. Fox, GE, letter forwarding SSAR markup of selected portions of Section 6.5, addressing discussion items of GE/NRC Plant Systems Branch conference call on October 13, 1993.

Fiche: 76892:197-76892:203

scn: $\quad 9310210302$

J. Fox, GE, letter forwarding LCO 3.6.1.6 and associated bases for review and comment.

Fiche: $\quad$ 76917:334-76917:343

acn: $\quad 9310260257$

J. Fox, GE, letter forwarding SSAR markup of GSI 82 that responds to issues raised by Plant Systems Branch during October 8, 1993, telecon.

Fiche: 76914:321-76914:326

acn: $\quad 9310250293$

J. Fox, GE, letter forwarding Section 5.0 of TS incorporating agreements reached between NRC and GE on Paragraph 5.7.2.4, primary coolent sources outside containment and Paragraph 5.7.2.13, explosive gas and storage tank radioactivity monitoring program.

Fiche: $\quad$ 76913:183-76913:188

acn: $\quad 9310260131$

J. Fox, GE, letter forwarding responses to NRC questions on ABWR certified design material Document 25A5447. Changes will be incorporated in next revision of document currently scheduled for mid-November 1993.

Fiche: $\quad$ 76959:155-76959:229

acn: $\quad 9310270056$

J. Fox, GE, letter forwarding justification of number of cycles/events specified in Table 3.9-1 supporting accelerated ABWR review schedule.

Fiche: $\quad$ 76924:322-76924:326

acn: $\quad 9310260352$ 
October 22, 1993

October 22, 1993

October 22, 1993

October 22, 1993

October 25, 1993

October 26, 1993

October 26, 1993

October 27, 1993

October 27, 1993

October 28, 1993
J. Fox, GE, letter forwarding SSAR markups of Section 6.5 and Appendix 6A mupporting sccolerated.ABWR schodule.

Fiche: 76986:354-76986:356

acn: $\quad 9310270008$

J. Fox, GB, letter forwarding SSAR markups reaponding to Open Items 1.2.6-1 and 2.61 regarding accolerated ABWR schedule.

Ficho: 76985:302-76985:305

acn: $\quad 9310270011$

J. Fox, GE, letter forwarding TS LCO 3.5.1, "ECCS Operating," and associatod bases, incorporating P\&R roviow comments and agreements between NRC and GE on use of CTG or ACIWA in LCO.

Fiche: $\quad 76985: 276-76985: 301$

acn: $\quad 9310270040$

J. Fox, GE, letter forwarding LCOs 3.8.1, 3.8.4, and 3.8.7 and associated bases, incorporating agreements recently reached between NRC and GE. Notifies that in LCO 3.8.7, Conditions A \& B from P\&R version dated August 31, 1993, combined into one condition.

Fiche: 76995:126-76995:205

acn: $\quad 9310290032$

J. Fox, GE, letter forwarding LCO 3.6.1.6 regarding wetwell-to-drywell vacuum breakers and associated bases, incorporating agreements reached between NRC and GE. Fiche: $\quad 77016: 255-77016: 263$

acn: $\quad 9310290034$

J. Fox, GE, letter forwarding LCO 3.8.9 and associated bases, incorporating P\&R review comments and recent agreements reached by NRC staff and GE. Requests markup comments as soon as possible.

Fiche: $\quad$ 76981:199-76981:216

acn: $\quad 9310280180$

J. Fox, GE, letter forwarding paper entitled, "ABWR Reactor Water Lovel System Capabilities," provided to D. Tang via fax on July 7, 1993, as basis of July 9, 1993, conference call.

Fiche: 76995:089-76995:095

acn: $\quad 9310280259$

J. Fox, GE, letter forwarding SSAR markup revising structural acceptance criteria of Subsection 3.8.1.5.

Fiche: $\quad 77056: 239-77056: 241$

acn: $\quad 9311030264$

J. Fox, GE, letter forwarding SSAR markups addressing recent GE/NRC discussions pertaining to 8h RCIC capability.

Fiche: 77056:236-77056:238

acn: $\quad 9311030273$

J. Fox, GE, letter forwarding proprietary SSAR murkups of Section 11.0 and Appendix 18F supporting accelerated ABWR schedule. Enclosure withheld.

Fiche: 77203:347-77203:357

acn: $\quad 9311120037$ 
Appendix C

October 29, $199 ' s$

October 29, 1993

November 1, 1993

November 2, 1993

November 2, 1993

November 3, 1993

November 3, 1993

November 3, 1993

November 5, 1993

J. Fox, GE, letter forwurding Figure 5.1-3 sheet 2, reflecting addition of de to SRV solenoids to indicate that solenoids de powered.

Fiche: 77108:238-77108:239

scn: , 9311040376

J. Fox, GE, letter forwanding SSAR markup that indicates de powered SRV solenoids on Figure 5.1-3, "Nuclear Boiler System P\&ID."

Fiche: 77166:224-77166:225

scn: $\quad 9311090202$

C. Poslusny, NRC, lottor forwarding independent quality review group initial comments on GE Nuclear Bnergy ABWR certified design material and SSAR.

Fiche: $\quad$ 77167:284-77167:330

scn: $\quad 9311120026$

J. Fox, GE, letter forwarding sample page of TS format that reflects need for GE document control and NRC staff requirement for maintaining STS format in WordPerfect.

Fiche: 77166:034-77166:035

san: $\quad 9311090157$

C.B. Brinkmen, ABB-CE, letter requests counsel on System $80+$ design certification project be pleced on service list to receive documents regarding GE ABWR design certification application and rulemaking.

Fiche: $\quad$ 77232:001-77232:001

sen: $\quad 9311120204$

J.F. Quirk, GE, letter forwarding draft of ABWR SSAR Tables 19.8-1 through 19.8-7 that heo been annotated with cross references to ITAAC. GE intends to include final version of enclosed draft material in ABWR SSAR amendment currently scheduled for submittal in mid-November 1993.

Fiche: $\quad$ 77101:344-77101:358

scn: $\quad 9311040238$

J. Fox, GE, letter forwarding discussion paper on ABWR schedule regarding primary contrinment pressure control EPG-low pressure venting for NRC/GE conference call scheduled for November 4, 1993.

Fiche: $\quad$ 77148:282-77148:290

acn: $\quad 9311090208$

J. Fox, GE, letter forwarding ABWR schedule regarding TS 3.6.1.6 bases addition, indicated by redlined text.

Fiche: $\quad$ 77145:355-77145:356

acn: $\quad 9311090225$

J.F. Quirk, GE, letter forwanding proprietary ABWR SSAR information. Advises that balance of previously designated proprietary pages reclassified as nonproprietary and will be revised in Amendment 33 with proprietary designation removed. Proprietary information withbeld.

Fiche: 77208:299-77208:304

acn: $\quad 9311150296$ 
November 9, 1993

November 9, 1993

November 9, 1993

November 15, 1993

November 16, 1993

November 22, 1993

November 22, 1993

November 23, 1993

November 30, 1993
J. Fox, GE, letter forwarding ABWR adaptation of new Section 5.0 of standard TS regarding administrative controls.

Fiche: 77264:088-77264:112

acn: $\quad 9311180150$

R.W. Borchandt, NRC, letter discussing GE relief from NRC motrication policy for both ABWR and SBWR dosigns.

Ficho: 77191:248-77191:253

scn: $\quad 9311150329$

T.H. Boyce, NRC, letter forwarding comments on GE ABWR Tier 1 certified design material.

Fiche: 77238:311-77238:336

sen: $\quad 9311180038$

C. Poslueny, NRC, letter forwarding replacement copy of independent quality review group initial comments on GE ABWR certified design material and SSAR, provided during November 10 and 11, 1993, meetings in San Jose, including missing pages due to xerographic error.

Fiche: 77293:001-77293:060

acn: $\quad 9312010388$

B. Strong, GE, letter requesting that John or Dale review rewritten sections, per licensee telecon.

Fiche: $\quad 77282: 340-77282: 346$

ecn: $\quad 9311190192$

R.W. Borchardt, NRC, letter forwarding advance copy of draft Commission paper, "Diversity in Method of Measuring Reactor Pressure Vessel Lovel in ABWR \& Simplified BWR," for distribution to appropriate GE staff.

Fiche: 77355-349-77355:358

scn: $\quad 9312030287$

L. Slegers, Siemens Power Corp., letter responding to inquiry re:arding diverse system for continuous water level measurement in BWR reactors.

Fiche: $\quad$ 77523:208-77523:208

ecn: $\quad 9312160186$

J. Fox, GE, letter forwarding markup changes to tangeatial spear stress regarding stresses in concrete and reinforcing steel.

Fiche: $\quad$ 77374:120-77374:124

scn: $\quad 9312030060$

J.F. Quirk, GE, letter discusses Final Design Approval (FDA) regarding design certification (DC) rulemaking. Informs that industry does not agree with preliminary secondary reference couse proposed by NRC staff and will submit forthcoming position paper.

Fiche: 71991:211-71991:213

acn: $\quad 9401310064$ 
Appendix C .

November 30, 1993

R.W. Borchardt, NRC, letter correcting November 22, 1993, letter transmitting draft Commission paper, by changing date of ACRS meeting and due date for GE comments from December 15 to December 9, 1993. Forwarding Commission paper for distribution to $G E$ staff.

Fiche: 77395:072-77395:081

acn: $\quad 9312100030$

December 2, 1993

J. Fox, GE, letter transmitting draft Amendment 33 to ABWR SSAR, Section 3.8.1.5, "Structural Acceptance Criteria."

Fiche: 77394:355-77394:359

acn: $\quad 9312080140$

December 7, 1993

J.F. Quirk, GE, letter forwarding proprietary portions of Appendix 3B of SSAR for advanced BWR. Report withheld.

Fiche: 77427:359-77427:360

acn: $\quad 9312100021$

December 7, 1993

J.F. Quirk, GE, letter forwarding nonproprietary Amendment 33 to "Advanced BWR SSAR," w/200 oeversize drawings.

Fiche: 77451:001-77464:034

acn: $\quad 9312100053$

December 7, $1993 \quad$ J.F. Quirk, GE, letter forwarding Revision 2 to Volumes 1 and 2 to 25A5447,

"Advanced BWR Certified Design Material."

Fiche: 77483:001-77484:297

acn: $\quad 9312140341$

December 8, 1993

J. Fox, GE, letter forwarding Owners Group changes incorporated in ABWR TS

Chapter 16, Amendment 33, supporting accelerated ABWR schedule.

Fiche: 77529:212-77529:301

acn: $\quad 9312200063$

December 9, 1993 J.F. Quirk, GE, letter requesting that all ABWR certification program correspondence be addressed to the undersigned, effective immediately.

Fiche: 77602:306-77602:306

acn: $\quad 9312170144$

December 13, $1993 \quad$ J.F. Quirk, GE, letter forwarding Amendment 33 to advanced BWR SSAR.

Fiche: 77633:156-77633:341

acn: $\quad 9312270058$

December 14, 1993 C. Poslusny, NRC, letter forwarding documents including information on vessel level instrumentation experience at European reactors.

Fiche: 77523:207-77523:230

acn: $\quad 9312160184$

December 29, 1993

R.W. Borchardt, NRC, letter forwarding detailed discussion of remaining issues and final position for resolution regarding ABWR containment system and severe accident review issues.

Fiche: 77674:325-77674:333

acn: $\quad 9401050084$ 
December 30, 1993

January 13, 1994

January 14, 1994

January 14, 1994

January 20, 1994

January 25, 1994

January 25, 1994

January 26, 1994

January 27, 1994
D. Crutchfield, NRC, letter forwarding advance copy of FSER on ABWR design regarding roviow of application for certification of ABWR design to inform of staff current findings and remaining open and confirmatory issues.

Fiche: 77749:002-77752:326

acn: $\quad 9401110210$

J. Fox, GE, letter responding to low-pressure venting Items 1, 3, 4, and 5 of GE ABWR containment system and severe accident review issues transmittod by December 29, 1993, letter with regard to containment EPGs.

Fiche: $\quad$ 77937:328-77937:332

acn: $\quad 9401260126$

J. Fox, GE, letter forwarding SSAR markups addreasing Open Items F19.3.3.2.1-1 and F19.3.3.2.1-2. Markups justify that RIP impeller and shaft replacement can tako place with fuel in vessel and removal of blade and drive of same assembly can be conducted. Fiche: 77937:333-77937:340

wen: $\quad 9401260123$

J.E. Wilkins, ACRS, summarizing 405th moeting of ACRS on January 6 and 7, 1994, regarding final report on design acceptance criteria process in certification of GE ABWR design.

Fiche: 78101:005-78101:009

acn: $\quad 9402070033$

J. Fox, GE, letter responding to containment emergency procedure guidelines issue on heat capacity temp limit portion of Open Issue F18.1-1, transmitted by December 29, 1993, letter.

Fiche: $\quad$ 77991:349-77991:357

acn: $\quad 9401310392$

J. Fox, GE, letter forwarding SSAR markups addressing Confirmatory Item F14.3.3-1 pertaining to ACRS comments on piping design acceptence criteria.

Fiche: 78086:349-78086:354

acn: $\quad 9402070239$

J. Fox, GE, letter forwarding SSAR markups addressing modeling uncertainty in PRA success criteria.

Fiche: $\quad$ 78086:341-78086:344

acn: $\quad 9402070250$

Transcript of January 26, 1994, briefing by GE in Rockville, Maryland regarding status of ABWR application for design certification.

Fiche: $\quad$ 78025:195-78025:260

acn: $\quad 9402030276$

C. Poslusny, NRC, letter forwarding staff feedback on ABWR Amendment 33 to SSAR and set of SSAR pages with marked up changes proposed by staff.

Fiche: 78091:001-78095:226

acn: $\quad 9402090184$ 
Appendix C

Fobruary 1, 1994

R. Ng, NUMARC, letter forwarding information from design PRA for ABWR appropriato for inclusion as Chapter 19 of design control document. Information besed on Section 19.8 of ABWR SSAR, "Important Features Identified by ABWR PRA" (Amendment 33).

Ficho: 78111:203-78111:240

acn: $\quad 9402080319$

February 1, 1994

T.H. Boyco, NRC, summarizing December 14, 1993, moeting with DOE in Rockville, Maryland to diecues progress of roviows for design certification of next-generation reactor designs. List of meeting attendoes and viowgraphs presented by industry representatives encloeed.

Fiche: 78106:292-78106:326

en: $\quad 9402140161$

February 2, 1994

C. Poslueny, NRC, letter providing round two of staff feedbeck on ABWR Amendment 33 to SSAR, cortified design material and TS.

Ficho: 78137:177-78137:216

acn: $\quad 9402140019$

February 3, 1994

R.W. Borchardt, NRC, letter forwarding comments on GE ABWR certified design material and SSAR. Comments requested within 2 weeks to allow prompt review and resolution by ITAAC review team.

Fiche: $\quad$ 78117:179-78117:308

acn: $\quad 9402140327$

February 4, 1994

J. Fox, GE, letter forwarding SSAR markup addressing response to Open Item F6.2.1.91 , pertaining to suppression pool strainers.

Fiche: $\quad$ 78144:332-78144:334

acn: $\quad 9402140251$

February 4, 1994

J. Fox, GE, letter forwarding SSAR markup addressing response to Open Item F4.2-1, pertaining to fuel burnup limit.

Fiche: 72013:355-72013:356

ecn: $\quad 9402140255$

February 4, 1994

J. Fox, GE, letter forwarding CDM markups addressing response to Open Item F8.3.3.6-1, pertaining to addition of non-Class 1E loads to Class $1 E$ system.

Fiche: $\quad$ 78137:336-78137:340

acn: $\quad 9402140263$

February 7, 1994

J. Fox, GE, letter forwarding SSAR markups addressing Open Item F1.9-1 regarding venting procedures, testing of RCIC bypass, turbine trip reliability, materials selection and increased capability for ACIWA system.

Fiche: 78139:301-78139:333

acn: $\quad 9402140207$

February 7, 1994

J. Fox, GE, letter forwarding SSAR markups addressing Open Item F19.2.3.3.8.3-1 regarding containment sump design.

Fiche: 78139:246-78139:300

acn: $\quad 9402140211$ 
Fobruary 7, 1994

Fobruary 7, 1994

February 7, 1994

Fobruary 7, 1994

February 7, 1994

February 9, 1994

Fobruary 9, 1994

February 10, 1994

Fobruary 10, 1994
J. Fox, GE, letter reeponding to low-pressure venting Item 2 transmitted by NRC December 29, 1993, letter regarding containment system and severe sccident reviow isaves, including containment emergency procedure guidelines iseves.

Ficho: 78137:299-78137:305

ecn: $\quad 9402140212$

J. Fox, GE, letter forwarding proprietary SSAR markup addressing response to Open Item P4.2-1 regarding fuel burnup limit. Enclosure withheld.

Fiche: $\quad 78150: 311-78150: 311$

sen: $\quad 9402140312$

J. Fox, GB, letter forwarding SSAR markup eddressing response to Open Item F19.2.3.2.1-1 regarding ACRS concern with equipment tunnel protection.

Ficho: 78129:354-78129:360

acn: $\quad 9402140316$

J. Fox, GE, letter forwarding SSAR markup addressing responso to Open Item F19.2.3.3.7-1 regarding equipment survivability.

Fiche: $\quad 78129: 310-78129: 342$

scn: $\quad 9402140325$

H.J. Yang, NRC, letter concluding that control rod withdrawal block function of MRBM subsystem should not be included in SSAR Subsection 14.2.12.2.6, per reviow of reference NRC comments on adding MRBM testing information to SSAR Subsection 145.2.12.2.6.

Fiche: $\quad$ 78267:303-78267:304

ecn: $\quad 9402240235$

J. Fox, GE, letter forwarding H.Y. Yang February 7, 1994, letter, concludin: that control rod withdrawal block function of MRBM subsystem should not be incluind in Subsection 14.2.12.2.6 of SSAR.

Fiche: 78267:302-78267:304

acn: $\quad 9402240228$

J. Fox, GE, letter documenting plans to submit additional proprietary information on Chapters 11 and 18 as part of Amendment 34.

Fiche: 78233:324-78233:324

acn: $\quad 9402240240$

C. Tang, GE, letter forwarding markup of LCO 3.6.2.4 and bases to support 14-day AOT, with regard to ABWR SSAR Amendment 33, Item 9.6.5.2 concerning containment spray system for review.

Fiche: 72020:309-72020:320

scn: $\quad 9402240218$

J. Fox, GE, letter forwarding proposed modification to Subsection 1A.2.16 regarding identification of and recovery from conditions leading to inadequate core cooling (TMI II.F.2).

Fichi: $\quad$ 78267:310-78267:312

scn: $\quad 9402240365$ 
Appendix C

February 10, 1994

February 11, 1994

February 14, 1994

February 14, 1994

February 14, 1994

February 16, 1994

February 24, 1994

February 25, 1994

March 3, 1994

March 4, 1994
C. Poslusny, NRC, letter providing third round of staff comments regarding GE SSAR Amendment 33, including additional Plant Systems Branch, Standardization Project Branch, and markup of one TS page generated by staff audit.

Fiche: $\quad$ 78143:347-78143:359

acn: $\quad 9402160159$

A.A. Jamos, GE, letter forwarding CDM and SSAR markups addressing Open Item F14.3.2-1 regarding ACRS concerns on fires and floods, including Michelson tunnelrelated issues.

Fiche: $\quad$ 78267:067-78267:116

acn: $\quad 9402240369$

J. Fox, GE, letter forwarding revised SSAR markup addressing Open Item F6.2.1.9-1 regarding suppression pool strainers.

Fiche: $\quad 78316: 189-78316: 191$

acn: $\quad 9402280121$

J. Fox, GE, letter forwarding write-up on consequences of simultaneous withdrawal of control rod and CR FMCRD requested.

Fiche: 78316:234-78316:235

acn: $\quad 9402280122$

C. Poslusay, NRC, letter providing fourth round of staff feedback on ABWR Amendment 33 to SSAR and TS. Markup of two TS pages generated by staff audit included.

Fiche: $\quad$ 78278:344-78278:347

acn: $\quad 9402250024$

C. Poslusny, NRC, letter providing fifth round of feedback on ABWR regarding Amendment 33 to standard safety analysis and TS.

Fiche: $\quad 78300: 349-78300: 353$

acn: $\quad 9403010218$

J. Fox, GE, letter forwarding revised write-up on consequences of simultaneous withdrawal of control rod and FMCRD.

Fiche: $\quad$ 78367:355-78367:357

acn: $\quad 9403070334$

J. Fox, GE, letter responding to DBA suppression pool bypass open item of February 29,1993 , letter regarding containment systems and severe accident issues.

Fiche: $\quad$ 78446:346-78446:347

acn: $\quad 9403100272$

J. Fox, GE, letter updating J.F. Quirk November 5, 1993, letter regarding final reclassification of ABWR SSAR proprietary information on Chapters 11 and 18.

Fiche: $\quad 78500: 277-78500: 278$

acn: $\quad 9403110288$

C. Tang, Westinghouse, letter forwarding markups for LCO 3.3.1.4, incorporating Amendment 34 of SSAR.

Fiche: $\quad$ 78423:338-78423:345

acn: $\quad 9403090337$ 
March 4, 1994

March 8, 1994

March 8, 1994

March 10, 1994

March 18, 1994

March 18, 1994

March 23, 1994

March 24, 1994

March 30, 1994

March 30, 1994

March 31, 1994
J. Fox, GE, letter forwarding SSAR markup addressing EPG issue on HTCL.

Ficho: $\quad$ 78513:316-78513:324

acn: $\quad 9403140277$

A. Beand, GE, letter forwarding SSAR markups regarding manual fire fighting in control building for J. Holmes.

Fiche: 78503:268-78503:272

acn: $\quad 9403150235$

J. Fox, GE, letter forwarding CRD/RIP information.

Ficho: 78531:358-78531:359

acn: $\quad 9403150470$

J. Fox, GE, letter forwarding revised response to materials selection portion of Open Itom F1.9-1.

Fiche: 78538:325-78538:329

acn: $\quad 9403160151$

J. Fox, GE, letter forwarding revised response to DSER (SECY-91-235) Outstanding Issue 31.

Fiche: $\quad$ 78612:334-78612:340

acn: $\quad 9403220179$

C. Poslusny, NRC, letter documenting recent discussions held between NRC and GE staff regarding effort to resolve remaining open item identified in staff advance SE for ABWR.

Fiche: 78680:272-78680:273

acn: $\quad 9403290129$

M.A. Rowden, Fried, Frank, Harris, Shriver \& Jacobson, letter forwarding draft proposed rulemaking and draft rule form and content for ABWR design certification proceeding for review and conderation.

Fiche: 78738:298-78738:352

acn: $\quad 9403300122$

R.W. Borchardt, NRC, letter discussing development of certified design material for evolutionary reactor designs.

Fiche: $\quad$ 78710:001-78710:048

acn: $\quad 9403310223$

D.A. Dreyfus, DOE, letter forwarding draft, "Advanced Reactor Research \& Development Programs 5-Year Plan for Advanced Reactor Activities Under Energy Policy Act of 1992."

Fiche: 79015:001-79015:053

acn: $\quad 9404250187$

R.W. Borchardt, NRC, letter responding to March 9, 1994, letter regarding remaining issues on ABWR on Open Item F6.2.1.9-1.

Fiche: $\quad$ 78755:239-78755:241

acn: $\quad 9404050284$

J.F. Quirk, GE, letter forwarding revised "ABWR SSAR/Certified Design Material Cross Reference Material" for GE ABWR.

Fiche: 78751:250-78751:309

acn: $\quad 9404040096$ 
March 31, 1994

March 31, 1994

April 5, 1994

April 11, 1994

April 11, 1994

April 11, 1994

April 11, 1994

April 13, 1994

April 14, 1994

April 14, 1994
J.F. Quirk, GB, letter forwarding nonproprietary Amendment 34 to "Advanced BWR SSAR," for final design approval and dosign certification.

Ficho: $\quad$ 78880:001-78899:183

acn: $\quad 404110226$

J.F. Quirk, GB, letter forwarding proprietary portion of Amendment 34 to "ABWR SSAR." Propriotary portion withhold.

Fiche: 78861:232-78861:264

acn: $\quad 9404130156$

R.W. Borchardt, NRC, letter discussing preliminary findings from Vendor Inspection Branch inspection rogarding ABWR design.

Ficho: 78926:175-78926:177

scn: $\quad 9404190118$

S.L. Kirberg, GE, letter forwarding Chapter 21 engineering drawing indexes to be inserted into Amendment 34 to SSAR.

Fiche: 78879:259-78879:260

acn: $\quad 9404130367$

J. Fox, GE, letter informing of submittal of supporting accelerated ABWR schedule regarding suppression pool strainers, which will incorporate agreed upon requirements and includng sample calculation.

Fiche: $\quad$ 78873:358-78873:359

scn: $\quad 9404150141$

J.N. Fox, GE, letter forwarding proprietary modification pages of SSAR, Amendment 34 to replace pager mailed in March 31, 1994, submittal. Notifies that four additional Figures 6.3-76 through 6.3-79 in modification package withheld.

Fiche: $\quad 98695: 111-98695: 111$

acn: $\quad 9404180312$

J.N. Fox, GE, letter forwarding nonproprietary and proprietary modification pages to SSAR Amendment 34 and certified design material, Revision 3 to replace March 31, 1994, submittal.

Fiche: $\quad$ 78953:201-78953:276

acn: $\quad 9404180294$

J.F. Quirk, GE, letter forwarding "Advanced BWR Certified Design Material/ITAAC Review Guidance."

Fiche: 78878:002-78878:187

acn: $\quad 9404150146$

J. Fox, GE, letter forwarding submittal supporting accelerated ABWR schedule regarding suppression pool strainers.

Fiche: 78928:328-78928:334

acn: $\quad 9404180385$

D.A. Dreyfus, DOE, letter informing that deadline for stakeholder comments on "Draft 5-Year Plan for Advanced Reactor Activities Under Energy Policy Act of 1992," extended until May 2, 1994.

Fiche: $\quad 79004: 345-79004: 346$

acn: $\quad 9404250174$ 
April 19, 1994

April 19, 1994

April 25, 1994

April 26, 1994

April 28, 1994

April 28, 1994

April 28, 1994

April 29, 1994

May 3, 1994

May 11, 1994
J. Fox, OB, letter forwarding SSAR and CDM markups modifying selected pages of SSAR Chapter 12 and CDM Section 3.2.

Ficho: 78965:242-78965:256

ecn: $\quad 9404210179$

C. Poalueny, NRC, letter forwarding final SNL report on Melcor analysis for ABWR.

Ficho: 78983:028-78983:292

ecn: $\quad 9404250060$

J. Fox, OE, lecter forwanding SSAR markups resulting from April 20, 1994, telecon. Changes will be incorporated into next ameadment.

Fiche: 79044:24479044:248

ecn: $\quad 9404280237$

J.M. Taylor, NRC, letter aubmitting comments rogarding draft report, "5-year Plan for Advanced Reactor Activitien Under Bnergy Policy Act of 1992."

Ficho: 79078:237-79078:287

ecn: $\quad 9405030173$

J. Fox, GE, letter forwarding revised SSAR markups addressing suppression pool strinen issue.

Ficho: 79181:056-79181:068

scn: $\quad 9405050322$

J. Pox, GE, letter fonwanding PMCRD scrum tij ces for nominal charge pressure of 2134 paig and for minimum allowable charge presaure of 1850 paig.

Fiche: 79181:053-79181:055

scn: $\quad 9405050327$

M.A. Rowden, Fried, Frank, Harris, Shriver \& Jecobson, letter forwanding draft environ asecesment for proposed rulemaking on advanced boiling water reactor design certification application and draft notico of ieaunce of environ asseasment and draft finding of no significent impect.

Fiche: 79181:281-79181:304

scn: $\quad 9405060057$

J. Fox, GE, letter forwarding revised SSAR markups responding to commitments made at April 15, 1994, meoting in Rockvillo, MD, including additional information reflecting locking mechanisms of aubaseomblies and European experience and finalized TS for CRD removal - refueling.

Ficho: 79181:025-79181:036

scn: $\quad 9405050360$

R.W. Borchardt, NRC, letter identifying remaining actions by GE needed to complete ABWR reviow.

Fiche: 79274:071-79274:107

ecn: $\quad 9405110082$

J. Fox, GE, letter submitting supporting socelerated ABWR schedule, proposed technical epecification changes for LCO 3.7.1, 3.7.2, and 3.7.3.

Fiche: 80225:328-80225:354

acn: $\quad 9407140146$ 
May 13, 1994

May 20, 1994

May 25, 1994

May 25, 1994

May 25, 1994

May 25, 1994

May 26, 1994

May 31, 1994

June 7, 1994

June 8, 1994

June 8, 1994
R.W. Borchant, NRC, letter providing GB with additional staff comments on Amodenan 34 to ABWR SSAR.

Ficho: 79511:001-79511:047

cen: $\quad 9405250139$

J.F. Quirt, OB, lewer forwanding proprietury SSAR Section 11A.2 and 11A.4 to pecified NRR recipients listed on Attechment 1. Baclosure withhold.

Ficho: 79518:229-79518:241

cen: 9405260145

J.P. Quirt, $O B$, leter rembenitting affidavit for OB ABWR, propriotary information Section 18H, "Supporting Analyais for Emergency Control Operation Information."

Ficho: 79539:333-79539:336

cen: $\quad 9405270098$

J.F. Quirt, OB, leuter mbemitting Ameadmeat 35, propriatary information to GE's ABWR SSAR.

Ficho: 79806:177-79806:196

sen: $\quad 9406100224$

J.F. Quirk, OE, letter mubmitting Ameadment 35, nonpropriotary information to GE's ABWR SSAR and certified dosign material, Revision 4.

Ficho: 79769:001-79769:169

cen: $\quad 9406130022$

J. Fox, OE, letter aubmittal supporting sccelernted ABWR schodule - responso to staff comments on Ameodment 34 markups.

Ficho: 80241:309-80241:325

cen: $\quad 9407140169$

J. Fox, OE, letter providing information on ABWR containment sprays.

Ficho: 80222:316-80222:326

sen: $\quad$ 9407130176

R.W. Borchandt, NRC, letter rovising FSER for the ABWR to discuss the concern releted to the polential for fuel pool boiling.

Fiche: 79709:141-79709:144

sca: $\quad 9406070275$

R.W. Borchandt, NRC, letter approving requeat for withholding ABWR SSAR information from public dieclosuro.

Ficho: 79757:047-79768:353

sca: $\quad 9406140019$

J. Fox, GE, letter submittal aupporting accelentod ABWR schedule - TMI Item III.D.1.1(1).

Fiche: 80243:310-80243:311

sca: $\quad 9407140165$

J. Fox, OE, letter wubmittal supporting accelerated ABWR schedule - codes and ctendards.

Fiche: 80243:321-80243:325

sca: $\quad 9407140168$ 
June 9, 1994

Juno 16, 1994

Juno 23, 1994

July 8, 1994

July 12, 1994

July 13, 1994

July 13, 1994

R.W. Borchandt, NRC, letter providing reulits of Inepection Report No. 99900403/94-01 to OB.

Fiche: 79827:825-79827-302

sca: $\quad 9406170317$

R.W. Borchandt, NRC, lettor providing revised Inepection Report.

Ficho: $\quad$ 79853:004-79853:020

scn: 9406210355

J. Fox, OB, letter aubmitting Revision 6 to the ABWR SSAR Ameadment 5 and Revision 5 to the CDM.

Ficho: $\quad$ 800247:001-80024:243

ecn: $\quad 9406270333$

D.M. Crutchfield, NRC, letter providing reliability senunance program requirements to GE.

Ficho: 80188:333-80188:334

acn: $\quad 9407120142$

J. Fox, OB, letter submitting proposed modifications to the ABWR SSAR Amendmeat 35 and the CDM.

Ficho: $\quad$ 80222:247-80222:292

acn: $\quad 9407130180$

T.H. Boyce, NRC, lotter providing resolutions of DSER and DFSER isaves relating to PRA.

Fiche: $\quad$ *

scn: $\quad 9407250150$

W.T. Ruesell, NRC, letter providing final design approval (PDA) for the ABWR design to GE.

Fiche: 80268:037-80268:043

ecn: $\quad 9407180203$

* Not available at time of publication 


\section{FSER CONTRIBUTORS}

\section{NAME}

S. Adam

F. Alleaspach

A. Androde

H. Asher

T. Boyce

H. Brammer

W. Burton

C. Carpenter

J. Carter

M. Caseo

T. Chendrasekaran

T. Cheng

M. Chiramal

M. Clark

T. Collins

R. Correia

R. Denning

A. DiAngelo

D. Diec

R. Dube

R. Eckenrode

A. El-Bassioni

E. Fox

G. Galletti

G. Georgiov

C. Goodmen

R. Gramm

S. Groen

J. Guo

P. Harich

R. Hesselberg

J. Holmes

P. Hearn

T. Hiltz

C. Hinson

s. Hoffman

S. Hou

A. Howe

W. Huffman

M. Hum

G. Kelly

S. Koenick

J. Knox

J. Kudrick

P. J. Lengston

E. Lo

J. Leo

S. Lo
RRGPONSTRITLTY

Secrotary

Quality Acourance

Secretary

Structural Bngineering

ITAAC and Project

Management

Mechanical Engineering

Plant Systeme

Reactor Systems

Operations Eveats Analysis

Project Management

Plant Systems

Structural Engineering

Instrumentation \& Control

Secrotary

Reactor Systems

Reliability Assurance

Operations Events Analysis

Plant Systems

Reactor Systems

Safeguands

Human Factors

PRA

Emorgency Preparedness

Plant Procedures \& Training

Materials Engineering

Human Factors

Reliability Assurance

Secretary

Plant Systems

Secretary

Project Management

Plant Systems, (Fire

Protection)

Technical Specifications

Project Management

Radiation Protection

Project Management

Mechenical Engineering

Project Management

Project Management

Materials Engineering (ISI)

PRA

Project Management

Electrical Engineering

Plant Systems (Severe

Accidents)

Secretary

Instrumentation \& Control

Radiation Protection

Structural Engineering
NAMB

Y. Li

J. Lyoms

P. Magnanolli

M. Malloy

V. MeCreo

B. Mendeleohn

A. Mendiola

J. Monninger

W. K. Mortensen

J. Moulton

R. Nease

D. Nelson

S. Ninh

P. Noonan

D. Notley

R. Palla

K. Parczowskj

R. Pedersen

L. Phillipe

T. Polich

C. Poslusany

R. Ramirez

J. Raval

M. Reardon

H. Richings

R. Rothman

M. Rubin

D. Scaletti

J. Sharkoy

P. Shea

M. Snodderly

P. Sobel

J. Spraul

J. Stewart

B. Sweeney

F. Talbot

C. Tan

D. Tang

D. Terao

D. Thatcher

G. Thomes

J. Thompeon

E. Throm

H. Walker

J. Watt

J. Wigginton

J. H. Wilson

J. N. Wilson
RBSPONSIBILITY

Mechanical Engineoring

Plant Systems

Socretary

Project Management

Project Management

Safoguards

Initial Teat Program and QA

Containment Systems ans

Severe Accidents

Instrumentation \& Control

Project Management

Project Management

Project Management

Project Managoment

Licensing Assistant

Plant Systems (Fire Protection)

PRA

Chemical Engineering

Radiation Protection

Core Performance

Reliability Assurance

Project Management

Initial Test Program

Plant Systems

Project Management

Reactor Systems

Geoscience

Reactor Systems \& Core

Performance

Project Management

Reliability Assurance

Licensing Assistant

Severe Accidents

Geoscience

Quality Assurance

Instrumentation \& Control

Secretary

Initial Test Programs

Structural Engineering

Project Management

Structural, Mechanical \&

Materials Engineering

Electrical Engineering

Reactor Systems

Project Management

Project Management

Plant Systems

Plant Systems

Radiation Protection

Project Management

Section Chief for Project

Management 
Appendix D

Battelle Pacific $\quad$ Startup Teating
$\begin{gathered}\text { Brookhaven National } \\ \text { Laboratories }\end{gathered}$
Neactor Systems
Northwest Laboratories
$\begin{gathered}\text { Energy Tochnology } \\ \text { Engineering Center }\end{gathered}$

Idaho National USIs, GSIs

Engineering Laboratory

- Lawrence Livermore National Laboratory

Geotochnical \& Structural Engineering

SAIC

Plant Systoms 


\section{STAFF POSITION ON SHELL BUCKLING DUE TO INTERNAL PRESSURE}

\section{INTRODUCTION}

Generally, when people speak of shell buckling, they refer to the buckling of the shell uader external preesure. Therefore, the first reaction of moet people to the suggestion that internal pressure in a shell container can cause buckling is skepticism. This is quite understandable, because from experience with the design of spheres and cylinders closed by hemispheres, for instence, contrinment vessels in nuclear power plants, the membrane stresses in these shells are tensile when subjected to internal pressure. Containment vessels with the above-mentioned configurations are assessed for buckling due to potential external pressure. In addition, considerations are given to compressive and shear membrane stress fields, which can occur in containment shells during earthquakes or as a result of an internal asymmetric pressure due to a loss-ofcoolant accident (LOCA) or a variant distribution of pressure around the sircumference. This results in axial compression in some portions of the containment shell and shear across the shell section. Compressive hoop stress can also occur at the point of support of a containment vessel under internal pressure where the movement of the shell is restrained.

Because of their geometrical configurations, torispherical and ellipsoidal shells under internal preseure have a stress field in which membrane tension in the meridian direction and compression in the hoop direction exist with the potential for buckling if not properly designed. This can be shown theoretically and has been demonstrated experimentally. Most of the steel containments for pressurized water reactor (PWR) plants in the United States are of spherical or cylindrical with hemispherical dome configurations. For boiling water reactor (BWR) plants, steel containment configurations vary from an inverted bulb surrounded by a torus cylinder topped by a conical frustum, to a cylinder with an ellipsoidal shallow dome. It appears that all the drywell heads in BWR plants are torispherical. The steel containments and their appended steel components are designed in accordance with the requirements of the ASME Codes acceptable to the NRC at the time of the licensing application.

To determine the viability of the containment during a reactor severe accident including a core melt, it becomes necessary to know the ultimate capacity of the containment more precisely and with a margin of safety. This can be observed from Item D, "Containment Performence," contained in the enclosure to SECY-90-016, "Evolutionary Light Water Reactor Certification Isests and Their Relationship to Current Regulatory Requirements, " which states:
The containment should maintain its role as a reliable leaktight barrier by essuring that contrinment streseces do not exceed ASME service level C limits for a minimum period of 24 hours following the onset of core damage and that following this 24-hour period the containment should continue to provide a barrier against the uncontrolled release of fission products.

This requirement appears to be applicable only to the steel containment and its appended components, which are under internal pressure, and does not mention how buckling is to be considered because buckling is generally perceived to be a problem mainly for thin shells under extermal pressure as ovidenced by the requirements in ASME Code, Section III, Subsection NE. In view of these facts, it is escential that a rational criterion be established for evaluating buckling of shells under internal pressure. In the following, the criteria for buckling as contained in ASME Code, Section III, Subsection NE, and in Code Case N-284 are first examined to discern the relationship between the two and the basic philosophy behind them. On the basis of this understanding supported by the extensive theoretical and experimental studies available in the literature, it is believed that a determination can be made as to whether the stipulations in the NE subsections or Code Case N-284 on buckling can be applied to the buckling of the shell under internal pressure or separate new criteria need to be established.

\section{REVIEW OF ASME CODE BUCKLING CRITERIA}

\section{Subsection NE}

The design of the steel containment against buckling is besed on requirements contained in NE-3133 and in NE-3222. NE-3133 gives formulae to determine the allowable external pressure for different shell configurations. The external pressure thus determined is assumed to include factors of safety and capacity reduction factors. NE-3222.1 specifies the allowable values for the basic compressive stress that may arise from mechanical, thermal, and pressure loads. The basic maximum buckling stress values to be used for the evaluation of stability are to be either (1) one-third of the value of the critical buckling stress determined by one of the following methods: (a) rigorous analysis considering all effects that can influence buckling, (b) classical analysis reduced by margins (knockdown factors), and (c) model testing or (2) the value obtained from NE-3133. NE-3222.2 stipulates stability stress limits in percentages of the value given in NE-3222.1 as follows: (1) for design conditions 
and Level A and B service limits use 100 percent, (2) for Lovel C service limits use 120 percent, and (3) for Lovel D service limits use 150 percent, which can be translated into factors of safety of 3,2.5, and 2, respectively, for NE-3222.1(a). NE-3324.4 and NE-3322.6 give the formulae for determining the thicknesses of ellipsoidal and torispherical heads, respectively, for internal pressure with limitations on radii to avoid compressive stresses. The thicknesses are determined on the basis of Level A and B service limits.

\section{Code Case N-284}

The purpose of this case is to provide stability criteria for determining the structural adequacy against buckling of containment shells with more complex shell geometries and loading conditions than those covered by NE-3133. Even though the case lists a number of complex conditions, a careful reading of the case will lead one to conclude that the case applies basically to local buckling of stiffened and unstiffened shells under external or internal pressure, stringer buckling and general instability of the stiffened shell under external pressure. The basic compressive allowable stress values referred to by NE-3222.1 will correspond to a factor of 2 in this case. The stability stress limits referred to by NE-3222.2 in this case will correspond to the following factors of safety: $2,1.67$ and 1.34, respectively, for the three conditions of service limits as indicated under NE-3222.1(a). These factors of safety are the minimum values required for local buckling. The respective factors of safety for stringer buckling and general stability failures are required to be 20 percent higher than those for critical local buckling; that is, the factors of safety to be applied are 2.4, 2.0, and 1.6 for the three conditions of service limits. It is to be noted that in addition to the factors of safety, capacity reduction factors that account for the effects of imperfections and nonlinearity in geometry and boundary conditions and plasticity reduction factors that account for nonlinearity in material properties are to be applied in accordance with the guidance given in the Code Case. Further, it should be mentioned that Code Case N-284 has been endorsed in RG 1.84, Revision 27, with a condition that the effect of the presence of a large opening on the shell be considered.

From the above it can be stated that Code Case N-284 is 2 supplement to NE-3133 and NE-3222 and takes into consideration local buckling of the shell, whether stiffened or unstiffened, stringer buckling and general instability of the stiffened shell as a whole. Such consideration is lacking in either NE-3133 or NE-3222. As observed from above, the factors of safety for local buckling of the shell, whether stiffened or unstiffened, for stringer buckling, and for general stability failure of the stiffened shell are smaller than thoee for general buckling of unstiffened shells because, with stiffeners, the shell is less sensitive to imperfections and the stiffened shell has a higher resistance against buckling. Furthermore, local buckling of the shell, whether stiffened or unstiffened, has no effect on the stability of the shell as a whole. Therefore, it would be unnecessarily conservative to use the factors of safety as specified in NE-3222 for general stability of the shell for local buckling. Code Case N-284 states that the basic factor of safety of 2 is applied to buckling stress values that are determined by classic (linear) analysis that has been reduced by capacity reduction factors determined from lower bound values of test data. It should be noted that when Code Case N-284 is applied to shells under internal pressure, the influence of the internal pressure may reduce the initial imperfections and, therefore, higher values of capacity reduction factors may be used.

\section{CRITERIA FOR SHELL BUCKLING DUE TO INTERNAL PRESSURE}

From the above review and observation, the staff concludes that shell buckling due to internal pressure, as in the case of ellipsoidal and torispherical shells, should be evaluated on the basis of ASME Code Case N-284 as local buckling because the buckling of such shells under internal pressure is of the stable kind. After the first one or two buckles have formed, it is possible to keep on increesing the internal pressure with additional buckles appearing periodically, but there is no effect on the stability of the overall shell. However, it should be noted, that the formation of these circumferential buckling waves on the shell can fracture the joints with any components appended to this portion of the shell and damage such components as bellows, closure of openings, and other attachments. There is also the possibility that the shell wall itself will fracture during the formation of the buckles, if the shell steel material is brittle. With the continuous increase in the internal pressure, and after the cessation of the formation of buckles without any fracture, the shell will most likely fail by axisymmetric yielding.

\section{CONCLUSION}

On the basis of a careful review and evaluation of the NE subsections and Code Case N-284 on buckling, the staff recommends that the buckling of ellipsoidal and torispherical shell due to internal pressure be considered as local buckling and ovaluated on the basis of the criteria contained in Code Case N-284. 


\section{STAFF POSITION ON STEEL EMIBEDMENTS}

\section{INTRODUCTION}

GE used American Concrete Institute (ACD) 349 for the design of seismic Catogory I structures for the ABWR. The ataff has reviewed Appendix B to ACI 349 (up to the 1985 Edition), "Code Requirements for Nuclear Safety Related Concrete Structures," and teet data for anchor bolts from both the United States and foreign countries. The staff's primary concerns rogarding Appendix B to ACI 349 are discussed below and exceptions to Appendix B are noted.

The staff's primary concern about Appendix B to ACI 349 is the use of a basic assumption regarding the 45-degree concrete failure cone. This assumption might have been chosen for the sake of convenience. However, tests have not confirmed this assumption oven for single anchors. The problem becomes greater (less conservative) when an anchor is located near the free edge of the concrete or a group of anchors are closely spaced.

Appendix B to ACI 349 is deficient in that it has no provisions for anchor strength reduction when the anchor is located in cracked concrete, such as in the tension zono of a concrete slab. The 1988 Edition of the Uniform Building Code (UBC) has provisions for anchor strength reduction when an anchor is located in the tension zone.

\section{EXCEPTIONS TO APPENDIX B TO ACI 349}

(1) Section B.4.2, Tension, and Figures B.4.1 and B.4.2

This section and the figures specify that the tensile strength of concrete for any anchorage can be calculated using a 45-degree failure cone theory. The staff has disseminated the German test data questioning the validity of the 45-degree failure cone theory to licensees, architect/engineer, bolt manufacturers, and members of the ACI 349 Code Committee. The data indicated that the more appropriate failure cone was about 35 dogrees and the use of the 45-degree cone theory could be unconservative for anchorages of deep embedment and for the anchorage of groups of bolts. The ACI 349 Code Committee, having dore some research of its own, recently agreed with the staff's position. The Code Committee is making changes to this section. In the meantime, the staff position on issues related to this section is to ensure adoption of design approaches consistent with the test data through case-by-case review.
(2)

\section{Section B.S.1.1, Tension}

This section presents the following criterion for ductile anchors: the design pullout strength (force) of the concrete, as determined in Section B.4.2, shall exceed the minimum specified tensile strength (force) of the ateel anchor. Any anchor that meets this critorion is qualifiod as a ductile anchor; thus, a low safety factor cen be used. The staff believes that the criterion is deficient in two areas. One is that the design pullout strength of the concrete so calculated could bo higher than the actual strength, which is stated in Section B.4.2 above. The other is that anchor stool characteristics are not taken into consideration. For example, Drillco Maxi-Bolt Devices, Ltd., claims that its anchors are ductile anchors, thus allowing the use of a low safety factor. The strength of the Maxi-Bolt is based on the yield strength of the anchor steel, which is 724 mogapeacal MPa (105 ksi). The embedment length of the anchor, which is used to determine the pullout strength of the concrete, is based on the minimum specified tensile strength of the anchor steel of $862 \mathrm{MPa}(125 \mathrm{ksi})$. The staff believes that the 19-percent margin $(125 / 105)$ for the embedment length calculation is insufficient considering the variability of parameters affecting the concrete cone strength. The staff also questions the energy absorption capability (deformation capability after yield) of such a high-strength anchor steel. Therefore, in addition to the position taken with regard to Section B.4.2 above, the staff will review vendor- or manufacturer- specific anchor bolt behaviors to determine the acceptable design margins between anchor bolt strengths and their corresponding pullout strengths based on a concrete cone.

Section B.5.1.1(a) - Lateral Bursting Concrete Strength

This soction states that the lateral bursting concrete strength can be determined by the 45-degree concrete failure cone assumption. Since this assumption is wrong and is likely to be replaced as stated before, the staff believes that the lateral bursting concrete strength determination is also inappropriate and needs to be replaced. The staff will review the lateral bursting concrete strength provided by the concrete cover around anchor bolts and the lateral bursting force created by the pulling of anchor bolts against test data to determine if reinforcement against lateral bursting force needs to be provided on a case-by-case basis. 


\section{(3) Section B.5.1.2.1, Anchor, Studh, or Bare}

This section states that the concrete reaistance for shear can be determined by a 45-dogree half-cone to the concrete free surface from the centerline of the anchor at the shearing surface. Since the 45degree concrete failure cone for tension has been found to be incorrect, the etaff believes that the use of the 45-degree half-cone for thear should aleo be reexamined. Thus, the staff will reviow the adequacy of the shear capecity calculation of concrete cones on a case-by-cace basis with emphasis on the verification of methodology through vendor-specific toet data.

\section{(4) Section B.5.1.2.2(c), Shear Lurs}

This section states that the concrete resistance for each shear lug in the direction of a free edge shall be determined on the basis of the 45-degree halfcone assumption by considering the concrete free surface from the bearing odge of the shear lug. This is the same assumption as that ueed in Section B.5.1.2.1, and the staff has the same comment es stated in that section. Therefore, the staff's position rolated to the design of shear luge is to perform caso-by-case reviews. The staff review will emphasize verification of methodology through vendor-specific test data.

(5) Section B.7.2, Alternative Design Requirements for Expansion Anchors

This section states that the design strength of expansion anchors shall be 0.33 times the average tension and shear test failure loads, which provides a safety factor of 3 against anchor failure. The staff position is that the safety factor for design against anchor failure is 4 for wedge anchors and 5 for shell anchors, unless a lower safety factor can be supported by vendor-specific test data.

(0) Anchors in Tension Zone of Supporting Concrete

When anchors are located in a tensile zone of supporting concrete, the reduction in anchor capacity due to concrete cracking should be sccounted for in the anchor design. 


\section{STAFF POSITIONS AND TECHNICAL BASES ON THE USE OF AMERICAN NATIONAL STANDARDS INSTITUTE (ANSI)/AMERICAN INSTITUTE OF STEEL CONSTRUCTION (AISC) N690, "NUCLEAR FACIITTIES - STEEL SAFETY-RELATED STRUCTURES"}

The use of ANSI/AISC N690 (1984 Edition) for the design, fabrication, and erection of safety-related structures in the ABWR is acceptable when supplemented by the following provisions:

\section{STAFF POSITIONS}

(1) In Section Q1 . 0.2, the definition of secondary streses should apply to stresses developed by temperature loading only.

(2) The following notes should be added to Section Q1.3.6:

- When any load reduces the effects of other loads, the corresponding coefficient for that load should be taken as 0.9 , if it can bo demonstrated that the loed is always present or occurs simultaneously with other loads. Otherwise, the coefficient for that load should be taken as zero.

- Where the structural effects of differential settlement are present, they should be included with the dead loed D.

- For structures or structural components subjected to hydrodynamic loads resulting from a loss-of-coolant accident (LOCA) and/or safety/relief valve (SRV) actuation, the consideration of such loads should be as indicated in the appendix to Standard Review Plan (SRP) Section 3.8.1. Any fluid structure interaction associated with these hydrodynamic loads and those from tho postulated earthquake(s) should be taken into account.

(3) The stress limit coefficients (SLC) for compression in Table Q1.5.7.1 should be as follows:

- 1.6 instead of 1.7 in load combination 11.

- 1.4 instead of 1.6 in load combinations 7,8 , and 9.

- 1.3 instead of 1.5 (stated in footnoto (c)) for load combinations 2,5 , and 6 .
(4) The following note should bo added

For constrained (rotation and/or displacement) members aupporting safety-related structures, syctems, and components (SSCs), the stresses under load combinations 9,10, and 11 should be limited to those allowed in Table Q1.5.7.1 as modified by Provision 3 above. The ductility factors of Table Q1.5.8.1 (or Provision 5 below) should not be used in these cases.

(5) For ductility factors $\mu$ in Sections Q1.5.7.2 and Q1.5.8, the provisions of Item II.2 of Appendix A to SRP Soction 3.5.3 should be substituted for the ductility factors in Table Q1.5.8.1.

(6) In load combination 9 of Section Q2.1, the load

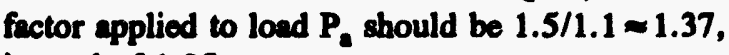
instead of 1.25 .

Sections Q1.24 and Q1.25.10 should be aupplemented with the following requirements rogarding the painting of structural steel:

- Shop painting is to be in accordance with Section M3 of load and resistance factor design (LRFD) specifications (American Institute of Steel Construction, "Load and Resistance Factor Design for Structural Steel Buildings and Its Commentary," Chicago, IL, 1986).

- All exposed areas after installation are to be field painted (or coated) in accordance with the applicable portion of Section M3 of the LRFD specification.

- The quality essurance requirements for the painting (or coating) of structural steel are to be in accordance with ANSI N101.4 (American Institute for Chemical Engineers, "Quality Assurance for Protective Coatings Applied to Nuclear Facilities," Now York, 1972) as endorsed by Regulatory Guide 1.54, "Quality Asourance Requirements for Prolective Contings Applied to Water Cooled Nuclear Power Plants," Revision 0. 


\section{TECHNICAL BASES}

(1) The standard defines "eccondary stress" as "any normal atress or shear etreses doveloped by the constraint of adjecent material or by selfconstraint of the etructure. The besic chanacterietic of a eccondary etrees is that it is solf limiting due to doformation-limited offects." This definition has been interproted by some to be applicable to the streases generated by mechenical (i.e., non-thermal) laeds at the structural discontinuities. The position clarifies the staff' interpretation.

(2) These notes provide guidance to the ueers regarding consideration of additional load effects in designing stoel structures. The notes are parts of SRP Sections 3.8.3 and 3.8.4.

(3) The research done in the last 12 years on the strength and stability of compreasion members indicates that the base curve (Structure Stability Research Council (SSRC) curvo in Figure G-1 of this appendix) ueed in arriving at the SLCs in SRP Sections 3.8.3 and 3.8.4 and in the atandard does not reflect available teat data. In doveloping the American Institute of Stoal Construction (AISC) building eppocification based on the loed and resistance factor doaign (LRPD) concept, the AISC changed the formula for compresaion members to reflect the data. The LRFD curve (with $\phi=1.0$ ) is also shown in Figure G-1. On the basis of the teet data, this curve has a minimum reliability index, $B^{1}$ of 2.6 (American Institute of Steol Construction, "Load and Resistance Fector Dexign Specification for Structural Steol Buildings and Its Commentary," Chicago, Illinois, September 1, 1986). The LRFD specification requires $\phi=0.85$ in establishing the resistance of compression members.

Figure G-1 shows the curves reflecting the SLCs of $1.0,1.4,1.5,1.6$ and 1.7 as applied to the streseses specified for the allowable stress design (ASD) of AISC. On the basis of the compariwon with the LRFD curve $(\phi=1.0)$, the following SLCs are recommended:

\footnotetext{
- $B$ is defined as a ratio of $\ln \left(R_{m} / Q_{\omega}\right)$ to $\left(V_{R}^{2}+V_{Q}^{2}\right)^{h}$ where: $\quad \mathbf{R}_{\mathbf{m}}=$ median value of reaistance

$\mathbf{Q}_{\mathrm{m}}=$ modian value of load

$V_{R}$ and $V_{Q}$ are the correeponding coefficients of variation.
}

- SLC of $1.6(\phi \approx 0.95)$ for load combination 11. This is rensonable for load combinations containing the offects of the two low probability ovents, that is, safe shut down carthquake (SSE) + LOCA.

- SLC of $1.4(\phi \approx 0.84)$ for load combinations 7,8 , and 9. This is appropriate for combinations containing the effects of the single low-probability events, that is, SSE, tornado, or LOCA.

- SLC of $1.3(\phi \approx 0.80)$ for loed combinations 2,5 , and 6 is recommended when the secondary atresees due to $\mathrm{T}_{0}$ aro included in the load combinations. This is consistent with the current position of allowing higher streseses under the effects of operating temperature.

(4) Neither the SRP nor the standard provide any guidance regarding the tolerable deformation of the constrained stoel members subjected to temperature growth under sustained $T_{n}$ or other LOCA loads. Statistically moaningful tost data simulating the inelastic behavior of such conatrained members under representative load combinations (including $T_{n}$ and $E_{\mathcal{J}}$ ) are not available. This provision precludes the instability condition arising from the effects of $T_{4}$ or other LOCA loads under load combinations 9, 10, and 11.

(5) The ductility factors in Table Q1.5.8.1 are either more liberal than those in SRP Appendix A to Section 3.5.3 (e.8., $\mu$ for compression members) or involve some inconsistencies in the definitions and interprotation of the formulas (0.g., formulas in Item 2.D of the table) given in the table. Therefore, until sufficient test-based justification for ductility factors listed in Table Q1.5.8.1 is provided, the staff position as stated in the appendix is recommended for use.

(6) This provision makes the load combination consistent with that in the SRP.

(7) An additional provision regarding the painting of structural stoel is provided. 


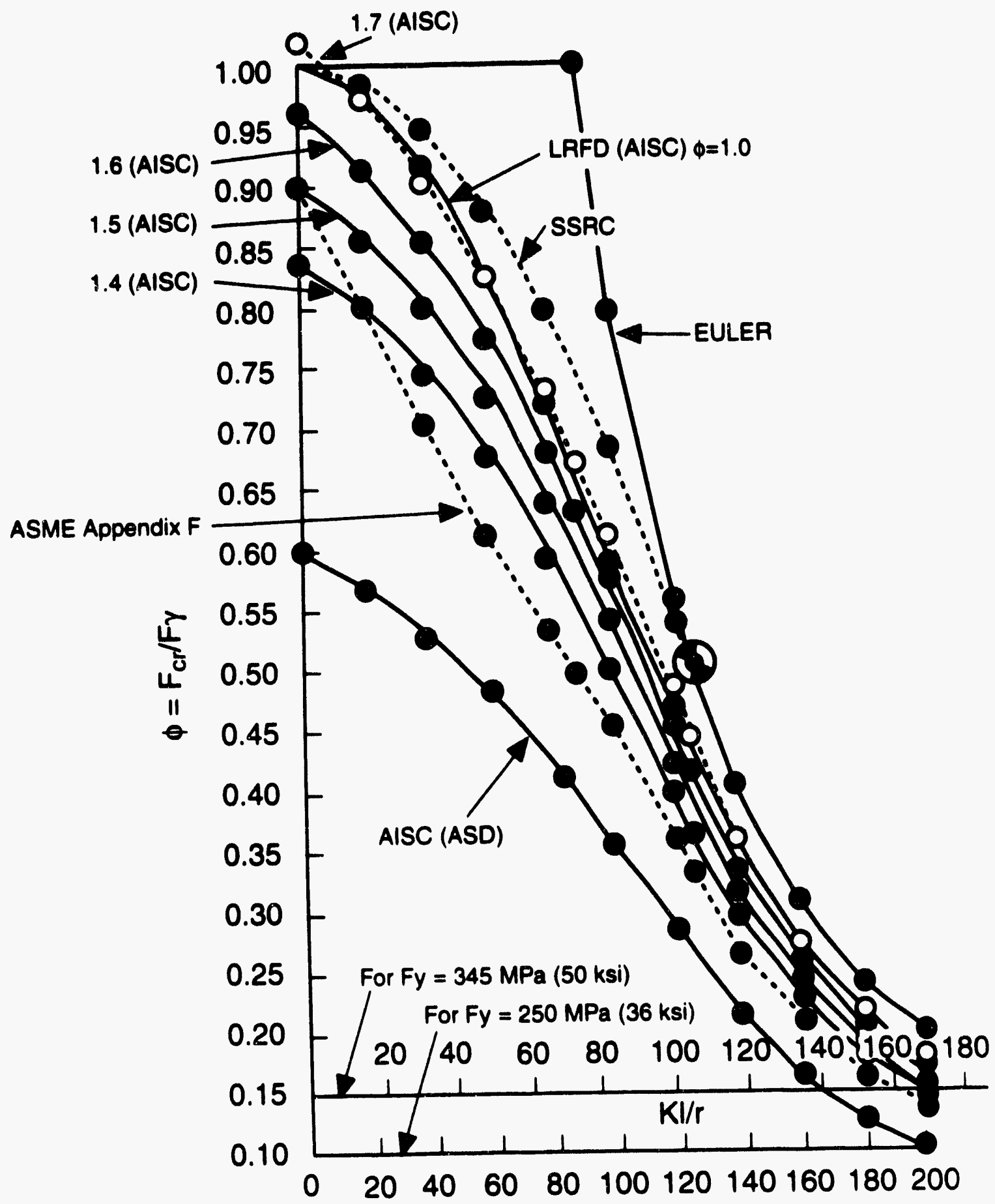

Figure G-1 Stability curves for axially loaded compression members, $E=200 \mathrm{GPa}(29,000 \mathrm{ksi})$ 


\section{DYNAMIC LATERAL SOIL PRESSURES ON EARTH RETAINING WALLS AND EMBEDDED WALLS OF NUCLEAR POWER PLANT STRUCTURES}

\section{INTRODUCTION}

In the design of earth retnining walls and ombedded exterior walls of nuclear power plant structures, it is importent to include the loads due to seismically induced lateral soil presoures. Standard Review Plan (SRP) Section 2.5.4, which deals with the stability of eubearfece materials und foundations, does not provide apecific roview criteria regarding acceptable procedures to determine the dynamic lateral soil pressures. However, it makes a generic statement that the applicant should satisfy the requirements of applicable codes and standards in designing the structures, systems, and components (SSCs) (in accordance with 10 CFR 50.55a). In addition, this SRP section states that state-of-the-art methods are to be used to design the structures. Section 3.5.3 of American Society of Civil Engineers (ASCE) 4-86 ("Seismic Analysis of Safety Related Nuclear Structures and Commentary ca Seismic Anlysis of Safety Related Nuclear Structures," Now York, NY, 1986), which is currently buing revised by ASCE, identifies cortain analytical methods to be used to establish dynamic lateral soil pressures, for the design of rethining walls or structures founded below grade surface (J.H. Wood, "EarthyiakeInduced Soil Pressures on Structures," Report No. ERRL 73-05, Earthquake Engineering Research Laboratory, California Institute of Technology, Pasadena, CA, August 1973, and H.B. Seed and R.V. Whitmen, "Design of Earth Retaining Structures for Dynnmic Loads," Proceedings of the ASCE Specialty Conference on Lateral Stresses in the Ground and Design of Earth Retaining Structures, Comell University, Ithaca, NY, 1970). These methods are based on the original analysis of this problem by Mononobe and Okabe (M-O) in the 1920s (ASCE 4-86).

Seed and Whitman (1970) presented a classical state-of-theart report at the ASCE Specialty Conference on Lateral Stresses in the Ground and Design of Earth-Retaining Structures held in 1970 . They presented data to show that seismic lateral pressure coefficients for cohesionless backfills computed by the $\mathrm{M}-\mathrm{O}$ method agreed reasonably well with the values developed in small-scale (model) tests. Subsequently, several researchers made significant contributions to this important subject area: (1) R.V. Whitman, "Seismic Design and Behavior of Gravity Retaining Walls," Proceedings of the ASCE Conference on Design and Performance of Earth Retaining Structures, Comell University, Ithaca, NY, 1990; (2) R. Richards, Jr. and D.G. Elms, "Seismic Behavior of Gravity Retaining Walls," ASCE Joumal, GT Division, Vol. 105, April 1979; (3) R.V. Whitman, "Seismic Design of Earth
Retuining Structures," Proceedings of the Second Intermational Conference on Recent Advances in Geotechnical Earthquake Engineering and Soll Dynamics, St. Louis, MO, March 11 through 15, 1991; (4) C.Y. Chang et al., "Analysis of Dynamic Lateral Soil Pressures Recorded on Lotung Reactor Containment Model Structure," Proceedings of the 4th U.S. National Conference on Earthquake Engineering, Palm Springs, CA, May 20 through 24, 1990; and (5) C. Soydemir, "Soismic Deaign of Rigid Underground Walls in Now England," Proceedings of the 2nd International Conference on Recent Advances in Ceotechnical Earthquake Engineering and Soil Dynamics, St. Louis, MO, March 11 through 15, 1991. In November 1992, the U.S. Army Corps of Engineers, acting as a consultant for the U.S. Naval Civil Engineering Laboratory, published a comprehensive technical report (with about 30 sample problems and solutions) on the seismic design of waterfront retaining structures (U.S. Army Corps of Engineers Technical Report ITL-92-11, "The Seismic Design of Waterfront Retaining Structures," Vicksburg, MS, November 1992). This report (prepared with input from a team of experts in the United States and Canada) summarizes the procedures recommended for computing dynamic lateral soil pressures and grouping them sccording to the expected displacement of the backfill and wall during seismic events. The Department of Energy is currently engaged in research and development work related to the area of dynamic lateral soil pressures. This brief summary of work done in the area of lateral pressures is not, by any means, complete; however, it gives a good indication of the apparently large uncertainties that appear to be unresolved in this area.

Bechtel Power Corporation, a consultant for General Electric for the ABWR standardized design of seismic Category I structures, has calculated the dynamic lateral soil pressures on retaining walls and embedded exterior walls of structures, using the $\mathrm{M}-\mathrm{O}$ method mentioned previously. In a section of Bechtel's proprietary report (Bechtel Power Corporation Proprietary Design Guide, C-2.44, Revision 0, August 1980 (version of Bechtel Topical Report, BC-TOP-4A, Revision 3, "Seismic Analysis of Structures and Equipment for Nuclear Power Plants," San Francisco, CA, November 1974)), it is stated that the M-O method was modified, where necessary, by procedures suggested by Wood in 1973 (EERL 73-05), and by some other researchers. Judging from the large amount of work reported in this area after 1979 (Whitman 1990, Richards and Elms 1979, Whitman 1991, C.Y. Chang et el. 1990, and Soydemir 1991, it appears that the procedures recommended in Bechtel's design guide mentioned above may not fully reflect the advances made 
in the state of the art in this aren aince 1979. The objoctive of this paper is to roviow as many aignificant rewearch papers available in the literature as poevible, and comment on tho appropriatences of Bechtel's procedures for calculating dynamic lateral coil preecures, for the ataff guidance in the reviow of the advanced light water reactor (ALWR), including ABWR, standard design.

\section{REVIEW OF CURRENT ANALYTICAL PROCEDURES}

Mononobe and Okabe (ASCE 4-86) propoeed a somewhat complicated equation to calculate the dynamic lateral soil pressures due to both horizontal and vertical earthquake accolerations. Their method, developed for dry cohesionlese backfill materials, was cesentially based on tho classical Coulomb's theory of earth pressures with the following assumptions: ·

The wall yields sufficiently to produce minimum active carth pressures.

A soil wodge behind the wall is at the point of incipient failure and the maximum soil shear strength is mobilized along the potential sliding surface, which passes through the toe of the wall.

(3) The soil wodge behind the wall acts as a rigid body so that seismic sccelerations may be considered uniform throughout the mass.

Seed and Whitman (1970) stated that Mononobe and Okabe apparently assumed that the total pressure computed by their analytical approach would act on the wall at the same position as the initial static pressure, that is, at one-third the height of the wall above the base. Other researchers, however, subsequently found that this assumption was not correet and that the dynamic lateral force increment acted at about the middle height of the wall (EERL 73-05 and Whitman 1970). In viow of the complex nature of the M-O equation that gives the total dynamic lateral pressure, Seed and Whitman also proposed a simplification of the M-O method to calculate the dynamic active lateral force increment. Seed and Whitman (1970) cited the work by Kapila, in 1962, on the determination of both active and passive lateral pressures by the M-O method, utilizing graphical construction.

While the M-O method was developed for yielding retaining walls, Wood (EERL 73-05) and Seed and Whitman (1970) found a solution for nonyielding walls, using elastic theory and assuming that material properties are constant with depth. Wood's solution predicted that the dynamic lateral forco incroment would act at about
0.63 times the height of the wall, which correeponded approximately to a parabolic distribution of carth prouaure unlike M-O's inverted triangular distribution. Wood's theoretical work was corroborated by experimental ahake table tests conducted by others who found that the mensured lateral pressures on nonyielding walls exceeded those predicted by the M-O method by a factor of 2 to 3 (Whitmen 1990). Finite element analyses in which the coil modulus increased with depth resulted in 5 percent to 15 percent smaller dynamic lateral presesures, with the resultant acting closer to 0.5 times the boight of the wall (Whitman 1990).

According to Whitman (1990), Richards and Elms mado a major advance in the area of dynamic lateral pressures by formulating a displacement-oriented solution that used the concept of allowable permanent movement of the gravity retaining walls (Soydemir 1991). Their approach, called the displacement-controlled method, differs from that of the M-O method which is strength controlled. Whereas some traditional designers using the M-O method are reported to have assumed less than the maximum design earthquake, the displacement-controlled approach of Richards and Elms permits the selection of a proper design acceleration coefficient (Whitman 1990). Further, their method, based on Newmark's sliding block analogy and retaining the $\mathrm{M}-\mathrm{O}$ equation, permits an evaluation of permanent displacement of retaining walls following an earthquake (Whitman 1991).

On the basis of a review of several researchers in this area, Whitman concluded that model test results have given continuing support for the use of the M-O equation for the design of relatively simple walls, $9.14 \mathrm{~m}$ (30 ft) or less in height; however, for higher walls and nonyielding walls, he recommends more careful analysis (Whitman 1990). Regarding basoment walls, Whitman, in his second statoof-the-art paper (Whitman 1991), stated that the use of Wood's theory (EERL 73-05) for nonyielding walls may seem logical, if the besement rests directly on hard rock and if the outside walls of the basement are well braced by floors. He further states that actual peak acceleration should bo used if any yielding or cracking of the walls is to be avoided. These requirements, according to Whitman (1991), can lead to quite large lateral soil pressures.

Chang of al. (1990) described a study that evaluated the uncertainties of several analytical solutions by comparing the computed and recorded dynamic lateral soil pressures on the embedded wall of the Lotung, Taiwan 1/4-scale model structure during several moderate earthquakes. In this study, a 1/4-scale reactor containment model structure was embedded at a depth of $4.57 \mathrm{~m}$ (15 ft) below the ground surface. The analysis of recorded data showed that the magnitude of dynamic lateral soil pressures was 
significantly lower then that predicted by published olantic solutions (ASCB 4-86 and BERL 73-05). The recorded dynamic lateral preseure increments were similar $1_{0}$, or lower than, those calculated by the M-O method. On the basis of the recults of this ctudy, Whitmen concluded that it may muffice to use the M-O equation logether with the sctual expected peak sccelerntion Whitmen 1991.

Nlthough the above conclunion may be generally true, it appears that Whitman's conclunion did not cover certain additional fiold data and discusesions provided by Chang of al. (1990). These relate to (1) the effect of variation of the backfill shoar modulus with dopth and (2) the offect of the rocking motion on the dynamic laternl prenaure distribution, which were mensured at the Lotung site. The coil shear modulus is generally smaller at the ground surface because of low confining preseure and gradually increasee with depth, contrary to the conetent modulus aseumption in elastic solutions. Probably because of this factor, the recorded dynamic earth presecures were mubetentially smaller then those given by the olastic solutions (Chang ot el. 1990). On the basis of a detailed study of the Lotung sito data, Chang of al. (1990) have concluded that the dynamic earth pressures acting on an embedded symmetrical structure are related primarily to soil-structure interaction (SSI) and that this phenomenon is differeat from that of a yielding retaining wall boing acted upon by on sctive earth pressure. Thus, the concept of limiting equilibrium used in the M-O method is not strictly applicable to the dynamic carth preasures on embedded structures.

Soydemir (1991) hes also recommended caution in using the M-O mothod indiscriminately. He points out that the M-O method is being used without checking whether the retaining structures yield or not, and whether the conditions assumed in the $\mathrm{M}-\mathrm{O}$ analysis are satisfied. Soydemir states that, oven though the M-O equation for active earth pressure conditions is quite appropriato for yielding walls, it may underestimate the dynamic lateral pressures acting on rigid, nonyielding earth retaining walls or structures.

Section 4.5 of Bechtel Design Guide C-2.44 (1980) states that the M-O method is used to evaluato the seismically induced lateral soil pressures in the carthquake-resistant design of both the retaining walls and the embedded portions of exterior walls of nuclear power plant structures. The Design Guide further states that, when the wall does not experience sliding or rotation, the elastic solution (EERL 73-05) becomes more appropriate. In auch cases, in addition to the "at reat" static preseures, all the reeulting dynamic forces are to be ixcreased by a factor of 2 for consideration of such nonyielding conditions (0.8., the embedded walls of massive structures.) The report atates that the value of 2 is based on the findinge of Wood (BERL 73-05) and aleo on the fect that "at reat" presenures are about twice the ective preenures. Since the factor 2 is for an infinitely long backfill, the Deaign Guide says that the sppropriate dactio solution can be uned for shorter leagthe of backfills. Section 4.5 of the Dexign Ouide is sileat about the seismic lateral preacures due to mubmerged backfill, for which procedures are available in the literature (H. Mateumwa of al., "Dynamic Soil and Water Prenaures on Submerged Soils," ASCE Journal of Ceotechnical Bngineering, Vol. 111, No. 10, October 1985).

\section{CONCLUSIONANDRECOMMENDATIONS}

On the basis of o roviow of the papers and reports cited above and aleo convernations with experienced engineers worting in this aren at univensitien, industry, and Government agencies, the etaff belioves that the calculation procedures auggeted in Bechtel Design Guide C-2.44 (1980) are generally adequate for walls with shallow embedment. However, the Design Guide does not specifically address soveral factors, such as the offect of depth of embedment of exterior walls of nuclear power plant atructures which have ombedments ranging from $12.2 \mathrm{~m}(40 \mathrm{ft})$ to $25.9 \mathrm{~m}(85 \mathrm{ft})$, in the case of ABWR.

The recults of roviewing thoee papers and reports can be cummarized as follows:

In determining the dynamic lateral coil preasures, it is noceseary to distinguish throe differeat types of atructures, each of which may require a diatinct analysis and evaluation. They are (a) gravity retaining walls and shoetpile walls, etc., with level or sloping beckfill starting at the same olevation as the top of the rotaining wall; (b) basomont walls in buildings with the superstructure above the ground (0.8., embedded walls of nuclear power plant atructures); and (c) completely buried underground structures (e.g., tunnels, undorground tanks).

(2) For rigid walls with shallow embedment, it coems appropriate to use the $\mathrm{M}-\mathrm{O}$ method using the peak ground acceleration coefficient.

(3) For deeply embedded besement walls with a masaive superatructure above ground, which may experience rocking components of motion, and for rigid gravity walls, which may undergo rotational displacements about the vertical axis, the wee of the M-O method does not seem appropriate. For such cases, the procedures 
recommendad in Bechtal Devign Ouide C-2.44 (1980) send to bo modified, in viow of the extracive amounh of mors receat wort dose in this are. Proper concidention chould be given to the setual obuditions (0.8., variations of roil properties and seismic socolerations with depth, flaxibility and expectad doformations of embedded walls) whillo determining the eppropriate method to calculate the lateral coil prescuires, as the U.S. Army report (ITL-92-11) hes attempled to do. In auch complex cences, the laterd coll preseures derived from the recults of on SSI analysis may be uned in conjunction with the preseures predicted by the M-O method to determine a rage of dynamic lateral premeures that could be expected to ect on the embedded walls. Thees revalte may aleo be compened, as a check, with the leteral will premoures that could be cetimated by uning the Uniform Building Codo provisions for tho ben stear. In case an applicant wishes to une the destic colution proponed by Wood (BERL 73-05), a caep-by-cane juatification for the fector 2 for nonyielding walls montioned in Bechtel Deaign Ouido C-2.44 (1980) mut be provided by the applicant. 


\section{APPENDIX I}

\section{EVALUATION OF ABWR PUMP AND VALVE INSERVICE TESTING PLAN (SSAR TABLSS 3.9-8 AND 3.9-9)}

\section{INTRODUCTION}

The etaff evaluated the ABWR pump and valve inservice teating (IST) plan, principally Section 3.9 .6 and Tables 3.9-8 and 3.9-9 of the SSAR, in eccordance with SRP Section 3.9.6, "Inecrvice Teeting of Pumpe and Valve." This SRP section provides review guidelinee for tho IST plan to comply with 10 CFR Part SO, Appeadix A, ODC 37, 40, 43, 46, 54, and 10 CFR Part 50, 50.55a(1). OB atated that the ABWR pump and valve IST plen would med the requirements of the 1989 Bdition of the Amoricen Society of Mechnical Engincen (ASMB) Boiler and Preanure Veceal Code, Section XI, which reforences the ASMB Opentione and Maintensuce (OM)-6 and -10, 1988 Addeada, for rules for IST of pumpes and valves. Therefore, this roviow focued on en ovaluation of compliance of the ABWR IST plen with the ASME OM-6 and OM-10, 1988 Addeada.

\section{EVALUATION}

The OB ABWR pump and valve IST plan is documented in Section 3.9.6 of the SSAR. Specific pump and valve IST parumoters and frequencios for mfory- related pumpo and valves are dolinented in Table 3.9-8 of the SSAR. Table 3.9-9 of the SSAR lists the presure icolation valves. Table 3.9-8 refers 10 epecific SSAR figures that are piping and instrumentation diagram (P\&ID\&) of the syatems included in tho IST plan. In addition, some performance characteriatices of pumps and valves are presented in system descriptions locatod in other rections of the SSAR.

The ABWR IST plan includes 27 systems in which certain valves and pumpe have been epecified for teating requirements in eccordance with the ASME Code. The ctaff reviowed in dotail the following eight ABWR systoms: control rod drive, contrinment isolation, main steam (nuclear boiler), service water, instrument air, atendby liquid control, reaidual beat removal (RHR), and reactor core isolation cooling (RCIC). These systems were selected becauve they were the rubject of BWR ASMB Code reliof aubmittals. The ataff aleo performed a limited reviow for the remaining 19 aystems.

Evaluation of the ABWR pump and valve IST plan conaisted of a dotailed roviow of Trable 3.9-8 of the SSAR and its supporting P\&IDa, which are preecented as figures in the SSAR. Table 3.9-8 gives the following information for each pump or valve in the IST plan: identification number, quantity, deacription, safety class, tost parameters, teat frequeacy, and SSAR figure number. In addition, it provides code catogory and function for the valves. All the pumps are grouped into a cinglo listing in Table 3.9-8; the valves are grouped by their ascociated syctom.

The detailed reviow of the IST plan included an independent confirmation of each of the parameters delineaced in Table 3.9-8 by andyais of the PAID SSAR figures and comparicon with the requirements in ASMB Code, Section XI. Provious experieace from BWR IST reliof aubmittals to the NRC was aleo frotored into this evaluation. In addition, guidance from NRC Generic Letter (OL) 89-04, "Ouideace on Developing Acceptable Inservice Teating Prognems," was included in this roviow. The IST plan was examined to ensure internal consistency between pumpe end valves that serve the sume function and have the samo anfety clascification and deaign.

As a revult of the detailed roviow, the NRC eat a lettor to OB on May 4, 1992, with an encloeed list of 57 general and epecific quections rogarding the ABWR pump and valve IST plan. Significent findings included are following: pumpa, valves, and aystoms misaing from the IST plan; inadequate decign to allow for IST; doviations from the requirements in ASME Code, Section XI, and imprectical or unrealietic teat frequencies for como pumps and valves. $O E$ responded to all the queetions in five exparate letters aubmitted on June 19, July 10, July 22 , July 30, and Auguat 14, 1992. In theec letters, GE aubmitted draft revisions of Table 3.9-8, certain P\&IDs, and rections of the ABWR SSAR. Whenever the staff discuesed an apparent conflict between two GE submittals, it conaidered the moat recent 000 to be applicable. As a recult of a celephone converation with the staff on October 6, 1992, to discues unresolved iseves after the reviow of the five rubmittals, $O B$ submitted a telefax revision on October 8, 1992, which responded to the iseves. This respones was discuesed with $G E$ in a tolephone call on October 9, 1992. After that call, OE documeated additional IST plan changes by a tolofax datod October 12, 1992.

As a recult of the review process, $\mathrm{GE}$ significantly rovised tho ABWR pump and valvo IST plan. Numorous P\&ID changes were made, which incorporated teat lines between check valves in serien and around other valves to allow for the capebility to perform the IST of each valve. The diesel generator fuel oil etorage end transfer system was added to the IST plan. The most significant changes were (1) the inclusion of exceptions to the Section XI base teating frequency requirement of once every 3 months and (2) a proposed alternative to the code testing requirement for the RHR system fill pumpa. 
OB included numbrous ASMB Cods exceptions for valves in Table 3.9-8 of the SSAR. The exceptions to the Section XI bese teating frequency requirement of once overy 3 months fall into one of the following evea catogorien:

(1) inecceaibility during power operation because of inerted containmeat and/or rediation in the main steam tunnel

avoidance of valve damage and impacts to power operation

Need for temporary croectio to carry ongoing cooling loada; a permanent crosetio would violate divisional separation

avoidance of cold/hot water injection into the reactor preseure vesed during power operation

mainteannce of pressure isolation during power operation

availability of inveatory only during rofueling outage

preseurization of the secondary containmeat above its operating limit, thus affecting power operations caused by a teat connoction of auficient aize for full-flow teating

Of these valve teating exceptions identified in SSAR Table 3.9-8, the most predominant bases for an exception were Categories 1 and 2. The next most frequent was Category 5.

In reviewing the Code exception catogories, guidance regarding the exception categories is given in the Code itself. Sections 4.2.1.2 and 4.3.2.2 of ASME OM-10 specifically permit extension of the valve test interval if testing "during power operation is not practicable." This criterion is also applied to quarterly and cold shutdown testing to allow for teating during refueling outages.

The staff ovaluated each valve in the ABWR IST plan in Category 1 or 2 and found them to be correctly characterized. In each cese, either the location of the valve or its function precluded its testing during power operation or cold shutdown. Thus, relaxation of the teet frequency for these valves is based on practicability. For these valves, the IST plan is in conformance with the ASME Codo.

Category 3 is used only for the three tostable check valves (F083) in the cooling water return line from noncesential coolene that are part of the reactor building cooling water eystem. This exception is based on requiring a tomporary crocetio to carry the ongoing cooling loads during a refueling outage. The underlying reason for this exception is that a permanent cronstio for this systom would result in - violation of the required separation between divisions during power operation. Since this is generally prohibited by ataff criteria in the SRP, this exception is another form of the Category 2 exception because it affects power operation. Therefore, the proposed valve teating frequency for this category is in conformance with Section XI of the ASME Code since leating overy 3 months is not practicable.

Categories 4, 5, and 6 all pertain to different aspects of power operation. Category 4 applies only to the standby liquid control system injection line outboand check valve FO07. Stroke teating this valve during power operation would introduce cold borated water into the coolant and thereby affect power operation. Thus, this categnry is actually analogous to Category 2 and is acceptable in sccordance with Section XI of the ASME Codo. The six Category 5 exceptions involve valves in the RHR, RCIC, and HPCF (high pressure core flooder) systems, which cerve as the pressure isolation valves delineated in SSAR Table 3.9-9 and are subject to plant tochnical specifications (TSs) for teating. Maintaining the reactor coolant system (RCS) preseure isolation boundary during power operation is an ecceptable reason for an exception to the Section XI base lesting frequency requirement of once every 3 months. The two Category 6 check valves (F023 and F094) are in the fuel pool cooling and cleanup system. The description of the function of these valves in the system substantiates the explanation that fluid inventory would not be available for testing excopt during a refueling outage. The justification for this exception is acceptable.

Category 7 applies to check valves F005A and F005B in the flammability control system. These two valves are both located in the secondary containment in a $15.2-\mathrm{cm}$ (6-in.) diameter pipe that is connected to the hydrogen recombiners. To full-flow test these valves during power operation, a high air flow would have to be introduced through this piping and exhaust into the socondary containment. This air would pressurize the secondary containment beyond its operational limit and thus affect power operation. Because it would be impracticable to perform this testing at power, this exception is acceptable.

In Table 3.9-8 of the SSAR, GE proposed not to meet the ASME Code, Section XI requirement to measure flow rate for the throe RHR system fill pumps (denoted E11-C002 in the P\&IDs). To justify its proposed alternative, GE 
stated that the piping will bo maintained full by a small fraction of the pump's flow capacity. OE also statod that the pumpe will be designed so that they will normally operate in the flat region of the pump proesure-flow performance curve. The pumpe will bo designed and analyzed to continuously operate in this low-flow regimo without any significent pump degradation. In addition, $G B$ atated that the ABWR TSs require the physical confir-. mation of a water solid RHR pipeline by opening a high point vent to confirm solid water flow of a 30-day frequency.

The primary function of the RHR system fill pumps is to maintain a water solid condition in the RHR pump diecharge piping. The RHR fill pumps are expected to run continuously providing a small makeup flow to compensate for any backleakage through the RHR system. These pumps will provide a low flow rate that is dependent on the piping system leakage characteristics at any given time. Without a constant, explicit, and definable piping system leak rate and path, the system resistance and makeup requirements cannot be set. Therefore, the pump flow rate may vary considerably around a small value and these variations likely would exceed the Section XI allowable limits, but actually be due to variations in backleakage rather than the pump's hydraulic performance. Since the pump will normally be operating on the flat region of the pump performance curve, the pump differential pressure is the hydraulic parameter of interest in monitoring pump performance. The ABWR IST plan requirement for meanuring pump inlet and outlet preseure as well as peak vibration velocity will allow detection of any significant dogradation in the pumpa' hydraulic or mechanical performance. In liew of measuring flow rato, the commitment to use pumps that are designed and analyzed to ensure both that the expected flow rate stays well within the flat portion of the preasure-flow curve and that no significant degradation occurs with the expected continuous lowflow operation combined with the proposed teating will provide an acceptable level of quality and safety. Therefore, this alternatives to the ASME Code, Section $\mathrm{XI}$, requirement is acceptable, pursuant to $10 \mathrm{CFR}$ $50.55 a(a)(3)(i)$.

\section{SUMMARY AND CONCLUSIONS}

The staff reviowed the GE ABWR pump and valve IST plan in accordance with requirements in ASME Code, Section XI, and applicable staff guidance. The IST plan is documented in Section 3.9.6 of the SSAR. The staff's evaluation was based on a detailed review of some selected systems in the IST plan and a partial assessment of the remaining systems.

The staff concludes that the ABWR pump and valve IST plan is in compliance with the 1989 Edition of ASMB Cod Section XI, except for the testing of the RHR system fill pumps. The staff reviewed proposed testing of the RHR fill pumps and determined that it will ensure an acceptable level of quality and safety. 


\section{HUMAN FACTORS ENGINEERING PROGRAM REVIEW MODEL AND ACCEPTANCE CRITERIA FOR EVOLUTIONARY REACTORS}

\section{MODEL DEVELOPMENT}

\subsection{Objectives}

One isewe to emerge from the review procese of evolutionary reactor control room designs was that complete detailed HSI design information would not be available for review prior to design certification and that certification would be based partially on the approval of a design and implementation process plan. The proceses must contain: (1) descriptions of all required HFE program eloments for the design, development and implementation of the evolutionary reactor human-system interfaces, (2) identification of predetermined NRC conformance review points, and (3) design acceptance criteria (DAC) and inspection, test, analysis and acceptance criteria (ITAAC) for the conformance reviews.

To review the designers process, it is necessary to: (1) assess whether all the appropriate HFE elements are included, (2) identify what materials are to be reviewed for each element, and (3) evaluate the proposed DAC/ITAAC to verify each of the elements. Since a process review has not been conducted previously by the NRC as part of reactor licensing and is not addressed in the presently available guidance, i.e., NUREG-0800, a firm technical basis for such a review is not available. To conduct the review, it is important to identify which aspects of the process are required to assure that HFE design goals in support of safe plant operation are achieved and to identify the review criteria by which each element can be assessed. Review criteria independent of that provided by the designer is required to assure that the design plan reflects currently acceptable human factors engineering practices and that it is a thorough, complete, and workable plan. Thus, technical basis for review of the process was developed and is described in this section. The specific objectives of this effort are:

1. To develop an HFE program review model to serve as a technical basis for the review of the process proposed for certification. The model requirements are that it be: (1) based upon currently accepted practices, (2) well-defined, and (3) validated through experience with the development of complex, high-reliability systems.

2. To identify the HFE elements in a system development, design, and evaluation process that are necessary and sufficient requisites to successful integration of the human component in complex systems.
3. To identify which aspects of each HFE element are key to a safety review and are required to monitor the process.

4. To specify the specific acceptance criteria by which HFE elements can be evaluated.

\subsection{Scope}

The scope of the HFE program review model was rostricted by two factors. First, those elements of a complete HFE program that are already adequately addressed by existing NRC requirements for license applicants were excluded from the scope of the model. Included in this category were training program development and the details of procedure development. The second category of exclusion were those elements that are the responsibility of other NRC review teams. This category includes human reliability analysis which, while important to HFE program development, is the responsibility of the SSAR Chapter 19 reviewers. Therefore, the scope of the model development described below was restricted to those aspects of HFE design review remaining after the above elements are excluded.

\subsection{Development Method}

A technical review of current HFE guidance and practices was conducted to identify important human factors program plan elements relevant to a design process review. Sources reviewed included a wide range of nuclear industry and non-nuclear industry documents, including those currently under development as part of the Department of Defense (DOD) MANPRINT program (Booher, 1990, DOD, 1989; DOD, 1990a). From this review a generic system development, design, and evaluation process was defined. Once specified, key HFE elements were identified and criteria by which they are assessed (based upon a review of current literature and accepted practices in the field of human factors engineering) were developed.

The generic HFE program review model was developed based largely on applied general systems theory (Bailey, 1982; DeGreen, 1970; Gagne, et al., 1988; VanCott et al., 1972; Woodson, 1981) and the DOD system development process which is rooted in systems theory (DOD, 1979a; DOD, 1990b; Kockler et al., 1990). Other DOD documents were utilized as well (see References section).

Applied general systems theory provides a broad approach to system design and development, based on a series of 
clearly defined dovelopmental steps, each with clearly defined and goals, and with specific management processes to attain them. System engineering has been defined as "...the management function which controls the total system development effort for the purpose of achieving an optimum balance of all system elements. It is a process which transforms an operational need into a description of system parameters and integrates those parameters to optimize the overall system effectiveness (Kockler et al., 1990).

Utilization of the DOD system development as an input to the development of the Generic HFE Program Model was based on several factors. DOD policy identifies the human as a specific element of the total system (DOD, 1990a). A systems approach implies that all system components (hardware, software, personnel, support, procedures, and training) are given adequate consideration in the developmental process. A basic assumption is that the personnel element receives serious consideration from the very beginning of the design process. In addition, the military has applied HFE for the longest period of time (as compared with industrial/commercial system developers), thus the process is highly evolved and formalized and represents the most highly developed model available. Finally, since military system development and acquisition is tightly regulated by federal, DOD, and military branch laws, regulations, requirements, and standards, the model provides the most finely grained, specifically defined HFE process available.

Within the DOD system, the development of a complex system begins with the mission or purpose of the system, and the capability requirements needed to satisfy mission objectives. Systems engineering is essential in the earliest planning period to develop the system concept and to define the system requirements. During the detailed design of the system, systems engineering assures:

- balanced influence of all required design specialties;

- resolution of interface problems;

- the effective conduct of trade-off analyses;

- the effective conduct of design reviews; and

- the verification of system performance.

The effective integration of HFE considerations into the design is accomplished by: (1) providing a structured topdown approach to system development which is iterative, integrative, interdisciplinary and requirements driven and (2) providing a management structure which details the HFE considerations in each step of the overall process. A structured top-down approach to NPP HFE is consistent with the approach to new control room design as described in Appendix B of NUREG-0700 (NRC, 1981) and the more recent internationally accepted standard, IEC 964
(1989) for advanced control room design. The approach is also consistent with the recognition that human factors issuces and problems emerge throughout the NPP design and evaluation process and therefore, human factors issues are best addressed with a comprehensive top-down program.

The systems engineering approach was expanded to develop an HFE Program Review Model to be used for the evolutionary reactor design and implementation process review by the incorporation of NRC HFE requirements.

\section{GENERAL MODEL DESCRIPTION}

In this section an overview of the model is presented to generally describe the HFE elements, products reviewed for each element, and the acceptance criteria used to evaluate the element.

The model is intended as the programmatic approach to achieving a design commitment to HFE. The overall commitment and scope of the HFE effort can be stated as follows: Human-system interfaces (HSI) shall be provided for the operation, maintenance, test, and inspection of the NPP that reflect "state-of-the-art human factors principles" (10 CFR 50.34(f)(2)(iii)) as required by 10 CFR 52.47(a)(1)(ii). For the purposes of model development "state of the art" human factors principles are defined as those principles currently accepted by human factors practitioners. "Current" is defined with reference to the time at which this model was developed. "Accepted" is defined as a practice, method, or guide which is (1) documented in the human factors literature within a standard or guidance document that has undergone a peerreview process, and/or (2) justified through scientific/industry research practices.

All aspects of HSI should be developed, designed, and evaluated based upon a structured top-down system analysis using accepted HFE principles based upon current HFE practices. HSI is used here in the very broad sense and shall include all operations, maintenance, test, and inspection interfaces, procedures, and training materials.

The model developed to achieve this commitment contains eight elements:

- Element 1 - Human Factors Engineering Program Management

- Element 2 - Operating Experience Review

- Element 3 - System Functional Requirements Analysis

- Element 4 - Allocation of Function

- Element 5 - Task Analysis

- Element 6 - Human-System Interface Design 
Element 7 - Plant and Emergency Operating Procedure Development

- Element 8 - Humen Factors Verification and Validation.

Tho elements and their interrelationships aro illustrated in Figure J.1. Also illustrated are the minimal set of items submitted to the NRC for review of the COL's HFE efforts. All NRC reviow items aro identified as falling into one of the five roview stages:

- HF Management Planning Roview

- Implementation Plan Reviow

- Analysis Results Roviow

- HSI Results Review

- Human Factors Verification and Validation

The materials reviewed at each stage are shown in Figure J.2.

A brief description of the purpose of each element follows:

Element 1. Human Fectors Engineering Program Mansarement

To assure the integration of HFE into system dovelopment and the achievement of the goals of the HFE effort, an HSI design team and an HFE Program Plan shall be established to assure the proper development, execution, oversight, and documentation of the human factors engineering program. As part of the program plan an HFE issues tracking system (to document and track HFE related problems/concerns/issues and their solutions throughout the HFE program) will be established.

\section{Element 2 - Operating Experience Review}

The accident at Three Mile Island in 1979 and other reactor incidents have illustrated significant problems in the actual design and the design philosophy of NPP HSIs. There have been many atudies as a result of these accidents/incidents. Utilities have implemented both NRC mandated changes and additional improvements on their own initiative. However, the changes were formed based on the constraints associated with beckfits to existing control rooms (CRs) using early 1980s technology which limited the scope of corrective actions that might have been considered, i.e., more effective fixes could be used in the case of a designing a new CR with the modern technology typical of advanced CRs. Problems and issues encountered in similar systems of previous designs shall be identified and analyzed so that they are avoided in the development of the current system or, in the case of positive features, to ensure their retention.
Blement 3 - System Runctional Requirements Analysis

System requirements shall be analyzed to identify those functions which must be performed to satisfy the objectives of each functional area. System function analysis shall: (1) dotermine the objective, performance requirements, and constraints of the design; and (2) establish the functions which must be accomplished to meat the objectives and required performence.

\section{Element 4 - Allocation of Functions}

The allocation of functions shall take advantage of human atrengths and avoids allocating functions which would be impacted by human limitations. To assure that the allocation of functions is conducted according to accepted HFE principles, a structured and well-documented mothodology of allocating functions to porsonnel, system elements, and personnel-system combinations shall be developed.

\section{Element 5 - Task Anglysis}

Task analysis shall provide the systematic study of the behavioral requirements of the tasks the personnel subsystem is required to perform in order to achieve the functions allocated to them. The task analysis shall:

- provide one of the bases for making design decisions; e.g., determining before hardware fabrication, to the extent practicable, whether system performance requirements can be met by combinations of anticipated equipment, software, and personnel,

- assure that human performance requirements do not exceed human capabilities,

- be used as basic information for developing procedures,

- be used as basic information for developing manning, skill, training, and communication requirements of the system, and

- form the basis for specifying the requirements for the displays, data processing and controls needed to carry out tasks.

\section{Element 6 - Human-System Interface Design}

Human engineering principles and criteria shall be applied along with all other design requirements to identify, select, and design the particular equipment to be operated/maintained/controlled by plant personnel. 


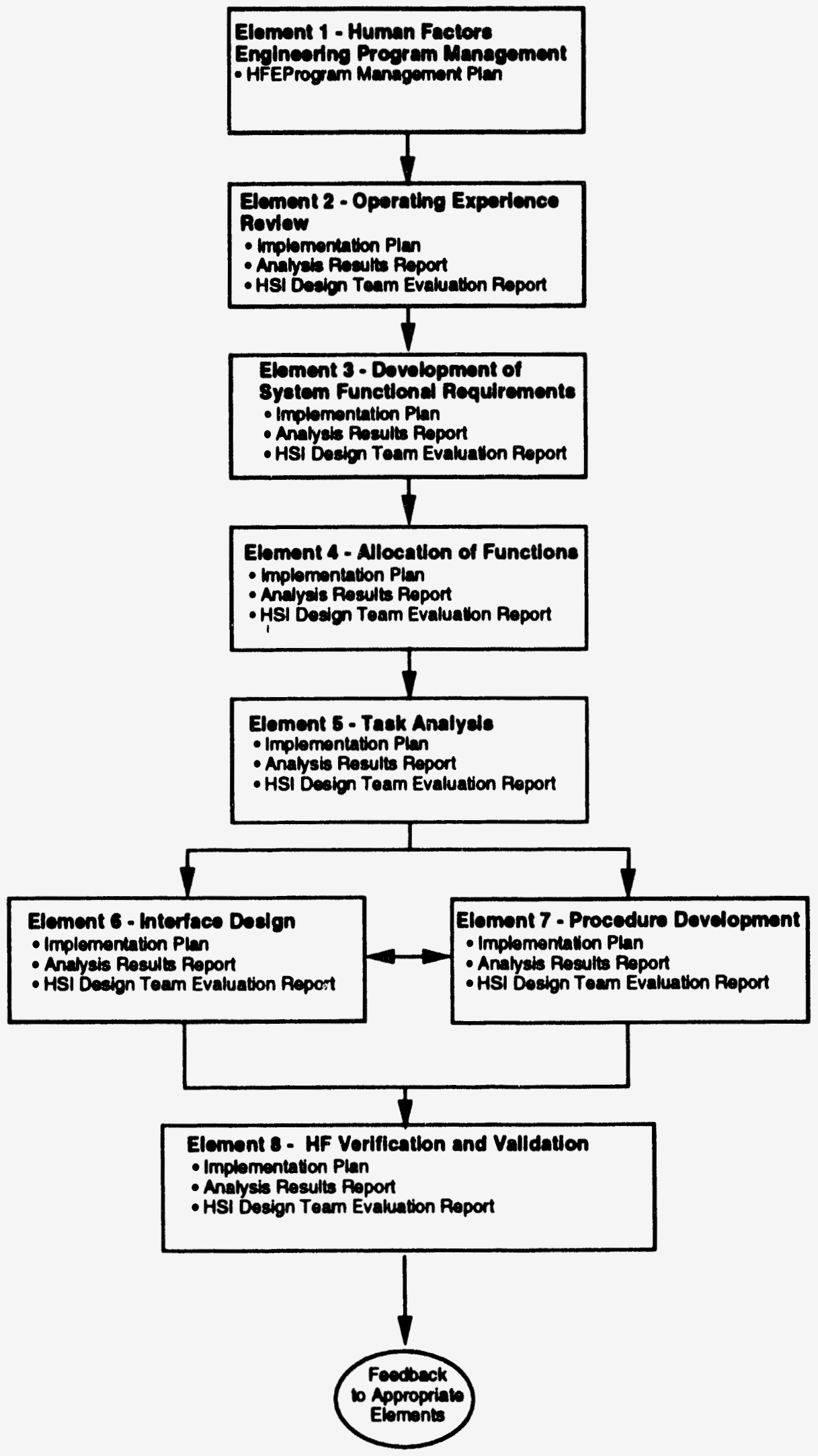

Figure J-1 Human factors engineering program review model elements 


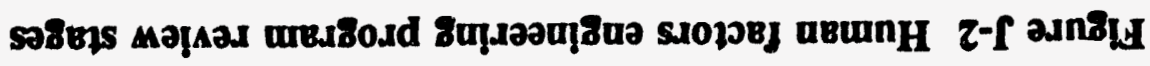

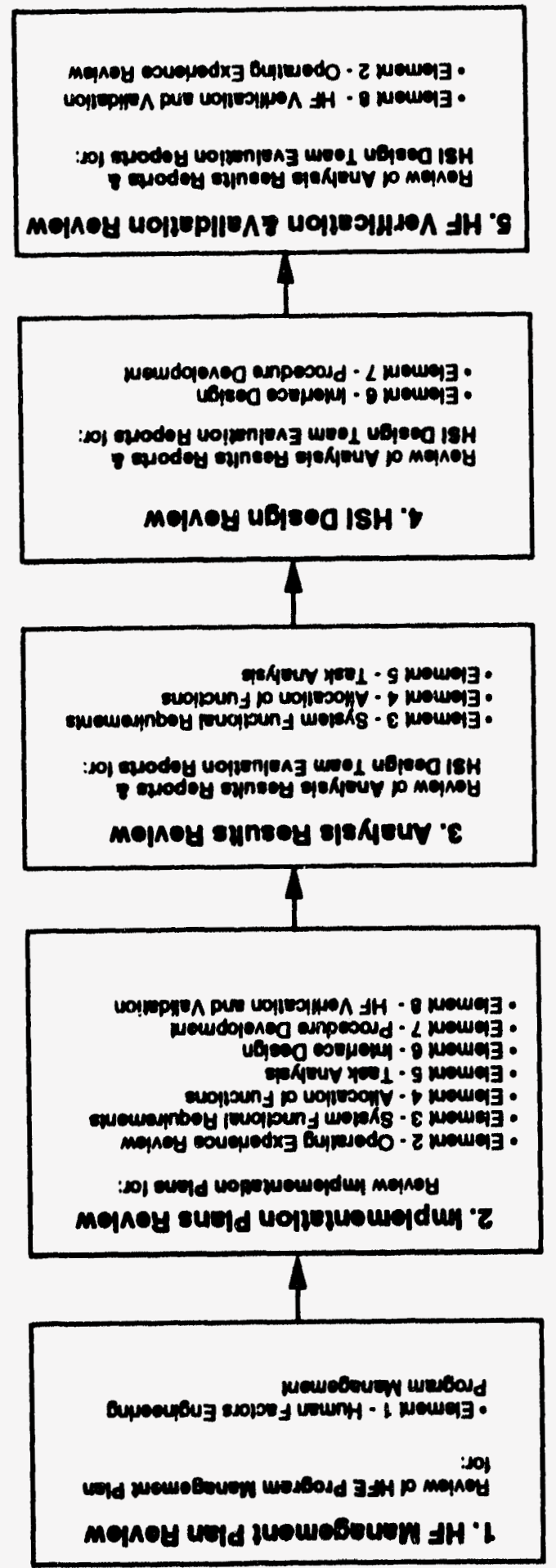


Element 7 - Plont and Emerrency Opentine Procedur: Development

Plant and Emergency Operating Procedures shall bo developed to support and guide humen interaction with plant systems and to control plant-related events and activities. Human engineering principles and criteria shall be applied along with all other design requirements to develop procedures that aro technically accurate, comprehensive, explicit, easy to utilize, and validated. The types of procedures covered in the element are:

- plant and system operations (including start-up, power, and shutdown operations),

- abnormal and emergency operations,

- preoperational, start-up, and surveillance tests, and

- alarm response.

Element 8 - Human Factors Verification and Validation

The successful incorporation of human factors engineering into the final HSI design and the acceptability of the resulting HSI shall be thoroughly evaluated as an intograted system using HFE evaluation procodures, guidelines, standards, and principles.

The specification for the NRC review materials and the acceptance criteria to be used for their evaluation are identified in the next section. Generically, each element is divided into three sections: Design Commitment, Inspection/Test/Analysis, and Decign Acceptance Criteria.

\section{Desien Commitment}

A concise and general statement as to the HFE objective of the Element.

\section{Inspection/Test/Analysis}

A specification of the inspections, tests, analysis, or other actions (i.e., some action that is required but which is not a specific inspection, test, or analysis, such as development of a program plan) to assure the achievement of the objective. Generally these are divided into three activities: planning, "analysis," and review. The set of materials to be provided to the NRC for review of the element is specified.

\section{Dexim Acceptunce Criteris}

Acceptance criteria are typically divided into four sections: General Critoria, Implementation Plan, Analysis Report, and HSI Design Team Reviow Report. The General Criteria represent the major statement of design acceptance criteria. These are the criteria the element is required to moot and which should govern the Implementation Plan, Analysis Report, and HSI Design Team Review Report dovelopment. The general criteria are derived from accepted HFE practices. These aro the criteria derived from the HFE model development and HFE literature and current practices roview.

The HFE Program Roviow Model requires that HFE elements bo governed by accepted HFE practices as specified in applicable codes, standards, and guidelines. Each element requires an identification of the codes, standards, and guidelines which are to be applied. Applicable codes, standards, and guidelines for the HFE Program Review Model Elements are provided below. With respect to Element 2 - Operating Experience Reviow, the documents listed also provide further issue description. While thees documents contain generally recognized accoptable approaches to the conduct of the HFE activity described by the element, several caveats should be identified:

- There may be inconsistencies or contradictions within and between documents. Such conflicts should be resolved on a caso-by-case basis depending upon the specific application under review.

- Not each document listed under a given element necessarily address all aspects of the element. In the conduct of a reviow of each element a combination of the applicable section of several of the identified document may be appropriate.

- It should not be inferred that the listed documents provide complete guidance for each and every activity encompassed by the element. HFE is not at a state of maturity to be confident that all HFE activities are adequately covered in codes, standards, and guidelines.

- The listed documents represent currently accepted documents in the buman factors community. Alternative approached can be found acceptable if judged by the reviewer to be based in firm rationale. Proposed alternative approaches should be evaluated on a case-by-case basis. 


\section{ELEMENT DESCRIPTIONS ACCEPTANCE CRITERIA}

AND

\subsection{Element 1 - Human Factors Engineering Program Management}

\section{DESIGN COMMITMENT:}

Human-system interfaces (HSI) shall be provided for the operation, maintenance, test, and inspection of the NPP that reflect "state-of-the-art human factors principles" (10 CFR 50.34(f)(2)(iii)) ' as required by 10 CFR 52.47(a)(1)(ii). All aspects of HSI shall be doveloped, designed, and ovaluated based upon a structured top-down system analysis using acceptod human factors engineering (HFE) principles based upon current HFE practices. HSI is used here in the broad sense and shall include all operations, maintenance, test, and inspection interfaces, procedures, and training needs. The tier 1 commitment addresses main control room and remote shutdown system functions and equipment. Local control stations should be included in the overall program.

State of the art human factors principles is defined as those principles currently accepted by human factors practitioners. "Current" is defined with reference to the time at which a program management or implementation plan is propared. "Accepted" is defined as a practice, method, or guide which is (1) documented in the humen factors literature within a standard or guidance document that has undergone a peer-review process and/or (2) can be justified through scientific/industry research/practices.

\section{INSPECTION/TEST/ANALYSIS:}

To assure the integration of HFE into system development: a HSI Design Team shall be established and a HFE Program Plan shall be established to assure the proper development, execution, oversight, and documentation of the human factors engineering program.

\section{DESIGN ACCEPTANCE CRITERIA:}

\section{General Criteria}

1. The primary goal of the HFE program shall be to developing an HSI which makes possible safe, efficient, and reliable operator performance and which satisfy all regulatory requirements as stated in 10 CFR. The general objectives of this program shall be stated in "buman-centered" terms which, as the HFE program develops, shall be objectively defined and shall serve as criteria for test and evaluation activities. Generic "human-centered" HFE design goals include:
- The operating team can accomplish all assigned takes within system dofinod timo and performance criteria.

- The system and allocation of functions will provide acceptable workload lovels to assure vigilance and to assure no operator overload.

- The system will support a high dogree of operating crew "situation awareness."

- Signal detection and ovent recognition requirements will be kept within the operators' information processing limits and will minimize the need for operators to mentally transform data in order to be usable.

- The system will minimize operator memory load.

- The operator interfaces will minimize operator error and will provide for error detection and recovery capability.

2. The program shall be developed using the following documents as guidance:

MIL-H-46855B: Human engineering requirements for military systems, equipment and facilities, 1979, (Department of Defense).

AR 602-1: Human factors engineering program, 1983, (Department of Defense).

DI-HFAC-80740: Human engineering program plan, 1989, (Department of Defense).

AR 602-2: Manpower and personnel integration (MANPRINT) in the material acquisition process, 1990, (Department of Defense).

DOD-HDBK-763: Human engineering procedures guide, 1991, (Department of Defense).

IEEE Std 1023-1988: IEEE guide to the application of human factors engineering to systems, equipment, and facilities of nuclear power generating stations, 1988, (IEEE).

\section{HSI Desian Team}

1. An HSI design team shall have the responsibility, authority and placement within the organization (as defined below) to ensure that the design commitment is achieved. 


\section{Appendix J}

2. The team shall be reeponsible for (1) the development of all HFE plans and procedures; (2) the overaight and reviow of all HFE design, dovelopment, tect, and ovaluation activities; (3) the initiation, recommendation, and provision of solutions through designated channels for problems identified in the implementation of the HFE sctivities; (4) verification of implementation of team recommendations, (5) assurance that all HFE activities comply to the HFE plans and procedures, and (7) scheduling of activities and milestones.

3. The scope of the team's responsibility shall include:

- Control and instrumentation equipment

- all operations, maintenance, test, and inspection of interfaces and facilities both within and outside the control room,

- procedures

- training requirements development.

4. The team shall have the authority and organizational freedom to ensure that all its areas of responsibility are accomplished and to identify problems in the implementation of the HSI design. The team shall have the authority to determine where its input is required, access work areas, design documentation. The team shall have the authority to control further processing, delivery, installation or use of HFE/HSI products until the disposition of a non-conformance, deficiency or unsatisfactory condition has been achieved.

5. The HSI design team shall be placed at the level in the COL organization required to execute its responsibilities and authorities. The team shall report to a level of management such that required authority and organizational freedom are provided, including sufficient independence from cost and schedule considerations.

6. The HSI Design Team shall include the following expertise:

\section{Technical Project Management}

- Bachelor's degree,

- five years' experience in nuclear power plant design or rperations, and

- three years' management experience.

\section{Syetem Enginearing}

- Bachelor's of Science dogree, and

- four years' cumulative experience in at least three of the following areas of systems engineering; design, development, integration, operation, and test and evaluation.

\section{Nuclear Engineering}

- Bachelor's of Science degree, and

- four years' nuclear design, development, test or operations experience

\section{Control and Instrumentation Engineering}

- Bachelor's of Science degree,

- four years' experience in design of process control systems, and

- experience in at least one of the following areas of C\&I engineering; development, power plant operations, and tost and evaluation.

\section{Architect Engineering}

- Bachelor's of Science degree, and

- four years' experience in design of power plant control rooms

Human Factors

- Bachelor's degree in human factors engineering, engineering psychology or related science,

- four years' cumulative experience related to the human factors aspects of human-computer interfaces. Qualifying experience shall include experience in at lease two of the following human factors related activities; design, development, and test and evaluation, and

- four years' cumulative experience related to the human factors field of ergonomics. Again, qualifying experience shall include experience in at least two of the following areas of human factors activities; design, development, and test and evaluation. 


\section{Plent Opentions}

- Have or have beld a eenior reactor operatior license, and

- two years' experience in relovant nuclear power plant operations.

\section{Computer System Engineerins}

- Bachelor's degree in Eloctrical Engincering or Computer Science, or graduate degree in other engineering dieciplino (0.8., Mechanical Engineering or Chemical Engineoring), and

- four years' experience in the design of digital computer systems and real timo systems applications.

\section{Plant Procodure Dovelopment}

- Bachelor's dogree, and

- four years' experience in developing nuclear power plant operating procedures.

\section{Personnel Training}

- Bachelor's degreo,

- four years' experience in the development of personnel training programs for power plants, and

- experience in the application of systematic training development methods.

\section{Systems Safety Engineering}

- Bachelor's degree in Science,

- certification by the Board of Certified Safety Professionals in System Safety, and

- four years' experience in System Safety Engineering.

Reliability/Availability/Maintainability/Inspectability (RAMI) Engineering

\section{Maintainability/lnspectability Engineering}

- Bachelor's of Science degree,

- four years' cumulative experience in at least two of the following areas of power plant maintainability and inspectability engineering activity; design, development, integration and test and evaluation, and
- experience in analyzing and resolving plant system and/or equipment related maintenance problems.

\section{Relinbility/Avnilability Bngineering}

- Bechelor's degree,

- four years' cumulative experience in at least two of the following areas of power plant reliability engineering activity; design, dovelopment, integration, and test and ovaluation, and

- knowledge of computer-based, human-interface systems.

7. The education and related professional experience of the HSI Design Team personnel shall satisfy the minimum personal qualification requirements specified in (6) above, for each of the areas of required skills. In those skill areas where related professional experience is specified, qualifying experience of the individual HFE design team personnel shall include experience in the technologies and techniques, of the particular skill area, utilized in the HSI design and implementation activities. The required professional experience presented in those personal qualifications are to be satisfied by the HSI design team as a collective whole. Therefore, satisfaction of the professional experience requirements associated with a particular skill area may be realized through the combination of the professional experience of two or more members of the HSI design team who each, individually, satisfy the other defined credentials of the particular skill area but who do not possess all of the specified professional experience. Similarly, an individual member of the HSI design team may possess all of the credentials sufficient to satisfy the qualification requirements for two or more of the defined skill areas.

8. Alternative personal credentials may be accepted as the basis for satisfying the minimum personal qualification requirements specified in 6 above. Acceptance of such alternative personal credentials shall be evaluated on a case-by-case basis and approved, documented and retained in auditable plant construction files by the COL Applicant. The following factors are examples of alternative credentials which are considered acceptable:

- A professional engineer's license in the required skill area may be substituted for the required Bechelor's degree.

- Successful completion of all technical portions of an engineering, technology or related science 
beccalaureate program may be subetituted for the Bachelor's degree. The nucceesful completion will be determined by a tranecript or other certification by en eccredited institution. For example, completion of 80 somester credit hours may be substituted for the beccalaureate requirement. The courses shall be in appropriate technical subjects relovant to the required skill areas of the HFB MMIS design team for which the individual will be responsible.

- Related experience may substitute for education at the rate of six semester credit hours for each year of experience up to a maximum of 60 hours credit.

- Where course work is related to job assignments, post secondary education may be subetituted for experience at the rate of two years of education for one year experience. Total credit for post secondary education shall not exceed two years experience credit.

\section{HIJE Issue Tracking System}

1. The tracking system shall address human factors issues that are (1) known to the industry (defined in the operating experience roviow, 800 Eloment 2) and (2) those identified throughout the life cycle of the ABWR system design, dovelopment and ovaluation.

2. The method shall document and track buman factors engineering issues and concerns, from identification until elimination or reduction to a level acceptable to the Team.

3. Each issue/concern that meets or exceeds the threshold effects established by the Team shall be entered on the log when first identified, and each action taken to eliminate or reduce the issue/concem should be thoroughly documented. The final resolution of the issue/concern, as accepted by the Team, shall be documented in detail, along with information regarding Team acceptance (e.8., person accepting, date, etc.).

4. The tracking procedures shall carefully spell out individual responsibilities when an issue/concem is identified, identify who should $\log$ it, who is responsible for tracking the resolution efforts, who is responsible for acceptance of a resolution, and who should enter closeout data.

\section{HTSE Proarm and Mnnarement Plon}

1. An HFE program munagement plan shall be doveloped to describe how the bumen fectors program shall bo cocomplished, i.e., the plan shall deecribe the HSI Deaign Toam's organization and composition and which lays out the offort to be undertaken and provides a technical approach, schedule, and management control atructure and tochnical interfaces to achiove the HFE program objectives. The plan is the single document which describes the designer's entire HFE program, identifies its elements, and oxplains how the elements will be managed. Generally, it shall address:

- The scope of the HSI design team's authority within the broader scope of the organization reeponsible for plant construction. Included within this scope shall be the authority to suspend from delivery, installation, or operation any equipment which is determined by the team to be deficient in regard to cetablishod human factors dosign practices and ovaluation criteria.

- The process through which the team will executo its responsibilities.

- The processes through which findings of the team are resolved and how equipment design changes that may be necessary for resolution are incorporated into the actual equipment ultimately used in the plant.

- The members and qualification of the team members.

- The process through which the team activities will bo assigned to individual team members, the responsibilities of each team member and the procedures that will govern the internal management of the Team.

- The procedures and documentation requirements of the HFE Issues Tracking System.

2. The HFE Program Management Plan shall provide the following information:

1. Purpose and organization of the plan

2. Literature and current practices review

3. Overall HFE program goals and objectives 
4. The relationship between the HFE program and the overall plant dexign program (organization and cobodulo).

\section{HSI Deaign Toam}

- Organization within the HFE program

- Ideatify and describe the primary HFB organization or function withia the organization of the lotal program, including charts to show organizational and functional relationshipa, reporting relationshipe, and lines of communication.

- Functions and intornal structure of the HFB Organization

- Describe the reeponsibility, authority and eccounatability of the HFE organization.

- Identify the organizational unit remponsible for each HFE tark.

- Describe the proceses through which management docisions will be medo regarding HFE.

- Describe the proceses through which deaign decisions will bo mado rogarding HFE.

- Deacribo all tools and tochniques (0.8., review forms, documentation) to be utilized by the Team to ensure they fulfill their responsibilities.

- Stafiing

- Describe the staffing of the HSI design team.

- Provide job descriptions of personnel of the HSI design toam.

- Indicate the assignment of koy personnel and provide their qualifications with regand to the areas of expertise indicated above.

6. HFE Issue Tracking System

- Literature and current practices review

- Responsibilities

- Responsibilities on issue identification

- Responsibilities for issue logging
- Remponaibilities for icano resolution

- Responsibilities for iseve cloceout

- Procedures

- Inovo ideatification

Description

Bffecto

Criticality and likelibood

- Isane resolution

Proposed eolutions

Implemented colution

Reaidual effects

Reaultant criticality and likelihood

- Documentation

- Audit of tho imero identification and tracking aystem

\section{HFB Requirements}

- Ideatify and deacribo the HFE requirements imposed on the design process

- List the andards and epecifications which are sources of HFE requirements

\section{HFB progrum}

Ideatify and deacribe the dovelopment of implementation plans, analyses, and ovaluation/verification of:

- Operating experience reviow

- Syetem functional requirements development

- Allocation of function

- Task analysis

- Intorface dosign

- Plant and emergency operating procedure dovelopment

- HF verification and validation

\section{HFE program milestones}

- Identify HFE milestones, so that evaluations of the effectiveness of the HFE effort can be mado at critical chock points and show the relationship to the integrated plant sequence of events.

- Provide a program schedule of HFE tasks showing:

- relationships between HFE elements and activities.

- reports

- reviows 
- Ideatify integnated doaign ectivities applicable to tho HFB program but epecified in other areas.

10. HFE documentation

- Identify and briofly describe each required HFB documented item.

- Identify procedures for accesedbility and reteation.

- Deacribe tho aupporting documentation and its audit trail maintainod for NRC audits.

\section{HFE in aubcontrector offorts}

- Provide a copy of the HFB requirements proposed for incluaion in each subcontract.

- Describe the manner in which the designer propoecs to monitor the subcontractor's compliance with HPE requirements.

\subsection{Element 2 - Operating Experience Review}

\section{DESIGN COMMITMENT:}

The accident at Three Mile Island in 1979 and other reactor incidents have illustrated aignificant problems in the actual design and the design philosophy of NPP HSIs. There have been many sudies a recult of these sccidenta/incidents. Utilities have implemented both NRC mandated changes and additional improvements on their own initiative. However, the changes were formed based on the constrints aseociated with backfits to exiating CR. using carly 1980s tochnology which limited tho scopo of corrective actions that might have been considered, i.e., more effective fixes could be used in the case of a designing a now CR with the modern technology typical of advanced CRs. Problems and issues encountered in similar systems of provious designs shall be identified and analyzed 80 that thoy are avoided in the development of the current system or, in the case of positive features, to ensure their retention.

\section{INSPECTION/TEST/ANALYSIS:}

- An operating experience review implementation plan shall be developed.

- An analysis of operating experience shall be conducted in accordance with the plan and the findings will be documented in an Analysis Results Report.

- The analyses shall be roviewed by the HSI design team and shall be documented in an ovaluation report.

\section{DESION ACCEPTANCE CRITERIA:}

\section{Geneml Criteris}

1. The following induetry operating experience iseves shall be reviowed:

- See the list of iseres ideatified in the "Operating Bxperience Roviow Inaves" attechment at the end of this documeat

2. The inaves ahall be roviowed and analyzed for:

- Human performance isaves, problems and sources of human error shall be identified.

- Deaign elemeats which support and enhance human performance shall be identified.

3. The following topics should bo included in interviows a a minimum:

- Display factors

- Control factors

- Information proseesing factors

- Communication factors

- Procedures

- Training factors

- Stafing and Job Dosign

4. The reviow shall include both a reviow of literature pertaining the humen factore issues related to similar syeteme and operator interviows.

5. The following sources both industry wide and plant or aubeyetem relevant should be included in review of the identified iesues:

- Government and industry studies of similar systoms

- Licenseo event reports

- Outago analysis reports

- Final safoty analysis reports and safoty ovaluation reports

- Humne engineering deficiencies identified in DCRDRs

- Modifications of the technical specifications for operation

- Internal memoranda/reports as available

6. Each operating experience issue shall be documented in the HFE tracking system.

7. The program shall be developed using the following documents as guidance and issue definition: 
NUREO-0737: Clarticarion of TMI action plan reguinements (Supplement 1, Itom I.C.5 "Fendback of Operating Experience to Plent Staff"), 1983, (U.S. Nuclear Regulatory Commiction).

NURBG-0933: A prioritization of generic safery lesues (Main Report and Supplemeats 1-12), 1991, (U.S. Nuclear Regulatory Commiecioa).

Draft NURBO-1449: Shuedown and low-power operailon at commencial nuclear power plants in the United States, 1992, (U.S. Nuclear Rogulatory Commiscioa).

BCO-HFRU-9446: The onsite analyais of the buman fuctors of operating eveats, 1991, (U.S. Nuclear Regulatory Commiacion - Moyer).

\section{Implementution Phn}

The plen shall deacribe the designer's approsech to operating experieace reviow. The plan ahall addreas the following:

- Documentation reviow and analyeis

- User murvey methodology (for conducting interviown) and analycis plans

- Method of documenting leweons learned

- Intogration of leceons learned into tho dosiga proceses

\section{Analysis Reaulis Renot}

The report shall addrees the following:

- Objectives

- Description of the methode

- Identification of any deviations from tho implementation plan

- Recults and diecuseion

- Conclusions

- Recommendationa/implications for HSI design

\section{HSI Desion Team Eysluntion Report}

The report shall addreas the following:

- The reviow methodology and procedures

- Compliance with implementation plan procedures

- Review findings

\subsection{Element 3 - Syetem Functiond Requirements Analyals}

\section{DESION COMMITMENT:}

Syctem requiremeates shall be analyzed to ideatify those functions which must bo performed to satisfy the objectives of ach functional aren. Syatem function analysis chall: (1) determine the objective, performance requirements, and constraints of the design; and (2) extablish the functions which muet be sccomplished to meer the objectives and required performance.

\section{INSPECTION/TEST/ANALYSIS:}

- A systom functional requirements analysis implementation plan shall be doveloped.

- An analysis of aystem functional requirements shall bo conducted in accordance with the plan and the findings will be documented in an analysis results report.

- The analysea shall be roviowed by the HSI design team and shall be documented in an evaluation report.

\section{DESION ACCEPTANCE CRITERIA:}

\section{GenenLLriteris}

1. System requirements shall determine system functions and the function shall determine the performance neceasery to carry out the function.

2. Critical functions shall be defined (i.e., those functions required to achiove major system performance requirements; or those functions which, if failed, could degrade system or equipment performance or pose a safety hazard to plant personnel or to the general public),

3. Safoty functions shall be identified and any functional interrelationship with non-safety systems shall be identified.

4. Functions shall be defined as the most general, yet differentiable means whereby the system requirements are met, discharged, or satisfied. Functions shall be arranged in a logical sequence so that any specified operational usage of the system can be traced in an end-to-end path. 


\section{Appendix J}

5. Functions shall be deacribed initially in graphic form. Function diagramming shall bo dons at soveral lovels, starting at a "top lovel" where a very groes picturs of major functions is described, and continuing to decompose major functions to soveral lower lovels until a epecific critical end-item requiremeat will emerge, 0.g., a piece of equipment, coftware, or en operator.

6. Detailed narrative descriptions shall be doveloped for each of the ideatified functions and for the overall systom configuration daxign iteolf. Bach function shall bo identified and dencribed in term of inputs (obeervable parnmoters which will indicate systom status), functional procesaing (control process and performance measures required to echieve the function), outputs, feedback (how to determine correct discharge of function), and interface requirements from the top down so that subfunctions are recognized as part of larger functional areas.

7. Functional operations or sctivities shall include:

- detocting signals

- measuring information

- comparing one measurement with another

- processing information

- acting upon decisions to produce a desired condition or result on the system or environment (e.8., system and component operation, actuation, and trips)

8. The function analysis shall be kept current over the life cycle of design development.

9. Verification

- All the functions necessary for the achievement of safe operation are identified.

- All requirements of each function are identified.

10. The effort shall be performed using the following documents as guidance:

IEC 964: Design for control rooms of nuclear power plants, 1989, (Bureau Central do la Commission Electrotechnique Internationale).

MIL-H-46855B: Human engineering requirements for military systems, equipment and facilities, 1979, (Department of Defense).
AD/A223 168: Systems engineering management gulde, 1990, (Departmeat of Defenee - Defense Syatems Managoment Colloge - Kockler, F. ot al.).

\section{Implementation Plen}

The plan shall deacribe the designer's approech to syatem functional requirements analysis.

The system functional requirements analysis implementation plen shall address:

- Literature and current practices reviow

- Describe the technical basis for the plan.

- List required system level functions

- Based on system performanco requirements.

- Graphic function descriptions

- o.g., functional flow block diagrams and timo line diagrams

- Detailed function narrative descriptions addressing:

- Observable parameters which will indicate system status

- Control procese and measure/data required to achiove the function

- How to determine proper discharge of function

- Analysis

- Define an integration of subfunctions that are closely related so that they can be treated as a unit

- Divide identified subfunctions into two groups

- Common achievoment is an essential condition for the accomplishment of a higher level function

- Alternative supporting functions to a higher level function or whose accomplishment is not necessarily a requisite for higher level function

- Identify for each integrated subfunction:

- Logical requirements for accomplishment (Why accomplishment is required)

- Control actions necessary for accomplishment 
- Parameters necessary for control action

* Criteria for evaluating the result of control actions

* Parameters necessary for the evaluation

- Evaluation criteria

* Criteria for choosing alternatives

- Identify characteristic measurement and define for each measurement important factors such as Load, Accuracy, Time factors, Complexity of action logic, Types and complexities of decision making, Impacts resulting from the loss of function and associated time factors.

- Verification

- Describe system function verification methodology.

\section{Analysis Results Report}

The report shall address the following:

- Objectives

- Description of the Methods

- Identification of any deviations from the implementation plan

- Results and Discussion

- Conclusions

- Recommendations/Implications for HSI Design

\section{HSI Desion Team Evaluation Report}

The report shall address the following:

- The review methodology and procedures

- Compliance with implementation plan procedures

- Review findings

\subsection{Element 4-Allocation of Function}

\section{DESIGN COMMITMENT:}

The allocation of functions shall take advantage of human strengths and avoids allocating functions which would be impacted by human limitations. To assure that the allocation of function is conducted according to accepted HFE principles, a structured and well-documented methodology of allocating functions to personnel, system elements, and personnel-system combinations shall be developed.

\section{INSPECTION/TEST/ANALYSIS:}

- An allocation of function implementation plan shall be developed.

- An analysis of allocation of function shall be conducted in accordance with the plan and the findings will be documented in an analysis results report.

- The analyses shall be reviewed by the HSI design team and shall be documented in an evaluation report.

\section{DESIGN ACCEPTANCE CRITERIA:}

\section{General Criteria}

1. All aspects of system and functions definition must be analyzed in terms of resulting human performance requirements based on the expected user population.

2. The allocation of functions to personnel, system elements, and personnel-system combinations shall be made to reflect (1) sensitivity, precision, time, and safety requirements, (2) required reliability of system performance, and (3) the number and level of skills of personnel required to operate and maintain the system.

3. The allocation criteria, rational, analyses, and procedures shall be documented.

4. As alternative allocation concepts are developed, analyses and trade-off studies shall be conducted to determine adequate configurations of personnel- and system- performed functions. Analyses shall confirm that the personnel elements can properly perform tasks allocated to them while maintaining operator situation awareness, workload, and vigilance. Proposed function assignment shall take the maximum advantage of the capabilities of human and machine without imposing unfavorable requirements on either.

5. Functions shall be re-allocated in an iterative manner, in response to developing design specifics and the outcomes of on-going analyses and trade studies.

6. Function assignment shall be evaluated.

7. The effort shall be perfcrmed using the following documents as guidance:

NUREG/CR-2623: The allocation of functions in manmachine systems: A perspective and literature review, 1982, (U.S. Nuclear Regulatory Commission - Price, H., et al.). 
NUREG/CR-3331: A methodology for allocation nuclear power plant control functions to human and automated control, 1983, (U.S. Nuclear Regulatory Commission Pulliam, R., et al.).

IEC 964: Design for control rooms of nuclear power plants, 1989, (Bureau Central de la Commission Electrotrotechnique Internationale).

AD/A223 168: Systems engineering management guide, 1990, (Department of Defense - Defense Systems Management College - Kockler, F. et al.).

\section{Implementation Plan}

The plan shall describe the designer's approach to Allocation of Function. The Allocation of Function Implementation Plan shall address:

- Establishment of a structured basis for function allocation

- Alternative systems analyses

- Specification of criteria for selection

- Trado studies

- Define objectives and requirements

- Identify alternatives

- Formulate selection criteria

- Weight criteria

- Prepare utility functions

- Evaluate alternatives

- Perform sensitivity check

- Select preferred alternatives

- Evaluation of function assignment

- The plan shall describe the tests and analyses that will be performed to evaluate the function allocation

\section{Analysis Results Report}

The report shall address the following:

- Objectives

- Description of the methods

- Identification of any deviations from the implementation plan
- Results and discussion

- Conclusions

- Recommendations/implications for HSI design

\section{HSI Desian Team Evaluation Report}

The report shall address the following:

- The review methodology and procedures

- Compliance with implementation plan procedures

- Review findings

\subsection{Element 5 - Task Analysis}

\section{DESIGN COMMITMENT:}

Task analysis shall identify the behavioral requirements of the tasks the personnel subsystem is required to perform in order to achieve the functions allocated to them. A task shall be a group of activities that have a common purpose, often occurring in temporal proximity, and which utilize the same displays and controls. The task analysis shall:

- provide one of the bases for making design decisions; e.g., determining before hardware fabrication, to the extent practicable, whether system performance requirements can be met by combinations of anticipated equipment, software, and personnel,

- assure that human performance requirements do not exceed human capabilities,

- be used as basic information for developing manning, skill, training, and communication reguirements of the system, and

- form the basis for specifying the requirements for the displays, data processing and controls needed to carry out tasks.

\section{INSPECTION/TEST/ANALYSIS:}

- A task analysis implementation plan shall be developed.

- An analysis of tasks shall be conducted in accordance with the plan and the findings will be documented in an analysis results report.

- The analyses shall be reviewed by the HSI design team and shall be documented in an evaluation report. 


\section{DESIGN ACCEPTANCE CRITERIA:}

\section{General Criteris}

1. The scope of the task analysis shall include all operations, maintenance, test and inspection tasks. The analyses shall be directed to the full range of plant operating modes, including start-up, normal operations, abnormal operations, transient conditions, low power and shutdown conditions. The analyses shall include tasks performed in the control room as well as outside of the control room.

2. The analysis shall link the identified and described tasks in operational sequence diagrams. A review of the descriptions and operational sequence diagrams shall identify which tasks can be considered "critical" in terms of importance for function achievement, potential for human error, and impact of task failure. Human actions which are found to affect plant risk in PRA sensitivity analyses shall also be considered "critical." Where critical functions are automated, the analyses shall consider all human tasks including monitoring of an automated safety system and back-up actions if it fails.

3. Task analysis shall begin on a gross level and involve the development of detailed narrative descriptions of what personnel must do. Task analyses shall define the nature of the input, process, and output required by and of personnel. Detailed task descriptions shall address (as appropriate):

- Information Requirements

- Information required, including cues for task initiation

- Information available

- Decision-Making Requirements

- Description of the decisions to be made (relative, absolute, probabilistic)

- Evaluations to be performed

- Decisions that are probable based on the evaluation (opportunities for cognitive errors, such as capture error, will be identified and carefully analyzed)

- Response Requirements

- Action to be taken
- Overlap of task requirements (serial vs. parallel task elements)

- Frequency

- Speed/Time line requirements

- Tolerance/accuracy

- Operational limits of personnel performance

- Operational limits of machine and software

- Body movements required by action taken

- Feedback Requirements

- Feedback required to indicate adequacy of actions taken

- Workload

- Cognitive

- Physical

- Estimation of difficulty level

- Task Support Requirements

- Special/protective clothing

- Job aids or reference materials required

- Tools and equipment required

- Computer processing support aids

- Workplace Factors

- Workspace envelope required by action taken

- Workspace conditions

- Location and condition of the work

- Environment

- Staffing and Communication Requirements

- number of personnel, their technical specialty, and specific skills

- Communications required, including type

- Personnel interaction when more than one person is involved

- Hazard Identification

- Identification of hazards involved

4. The task analysis shall be iterative and become progressively more detailed over the design cycle. The 
task analysis shall be detailed enough to identify information and control requirements to earble specification of detailed requirements for alarms, displays, data processing, and controls for humnn task accomplishment.

5. The task analysis results shall provide input to the personnel training programs.

6. The effort shall be performed using the following documents as guidance:

NUREG/CR-3371: Task analysis of nuclear power plant control room crews, 1983, (U.S. Nuclear Regulatory Commission - Burgy, D. et al.).

IEC 964: Design for control rooms of nuclear power plants, 1989, (Bureau Central do la Commission Electrotrotechnique Internationale).

DI-H-7055: Critical task analysis report, 1979, (Department of Defense).

MIL-STD-1478: Task performance analysis, 1991, (Department of Defense).

Implementation Plan

The plan shall describe the designer's approach to task analysis. The task analysis implementation plan shall address:

- General methods and data sources

- Gross task analysis

- Convert functions to tasiks

- Develop narrative task descriptions

- General statement of task functions

- Detailed task descriptions

- Breakdown of tasks to individual activities

- Develop operational sequence diagrams

- Critical task analysis

- Identification of critical tasks

- Detailed task descriptions

- Information and control requirements

- Initial alarm, display, processing, and control requirements analysis

- Develop a task-based I\&C inventory

- Application of task analysis results to training development
- Evaluation of task analysis

- The plan shall describe the methods that will be used to evaluate the results of the task analysis.

\section{Analysis Regults Report}

The report shall address the following:

- Objectives

- Deecription of the methods

- Identification of any deviations from the implementation plan

- Results and discussion

- Conclusions

- Recommendations/implications for HSI design

\section{HSI Desian Team Evaluation Report}

The report shall address the following:

- The review methodology and procedures

- Compliance with implementation plan procedures

- Review findings

\subsection{Element 6 - Human-System Interface Design}

\section{DESIGN COMMITMENT:}

Human engineering principles and criteria shall be applied along with all other design requirements to identify, select, and design the particular equipment to be operated/maintained/controlled by plant personnel.

\section{INSPECTION/TEST/ANALYSIS:}

- A Human-System interface design implementation plan shall be developed.

- An analysis of Human-System interface design shall be conducted in accordance with the plan and the findings will be documenteci in an analysis results report.

- The analyses shall be reviewed by the HSI design team and shall be documented in an evaluation report.

\section{DESIGN ACCEPTANCE CRITERIA:}

\section{General Criteris}

1. The design configuration shall satisfy the functional and technical design requirements and insure that the HSI will meet the appropriate HFE guidance and criteria. 
2. The HFE offort shall be applied to HSI both inside and outside of the control room (local HSI).

3. HSI design shall utilize the recults of the task analysis and the I\&C inveatory to assure the adequacy of the HSI.

4. The HSI and working environment shall be adequate for the human performance requirements it supports. The HSI shall be capable of supporting critical operations under the worst credible environmental conditions.

5. The HSI shall be free of elements which are not required for the accomplishment of any task.

6. The selection and design of HSI hardware and software approaches shall be based upon demonstrated criteria that support the achievement of human task performance requirements. Criteria can be based upon test results, demonstrated experience, and trade studies of identified options.

7. HFE standards shall be employed in HSI selection and design. Human engineering guidance regarding the design particulars shall be developed by the HSI designer to (1) insure that the human-8ystem interfaces are designed to currently accepted HFE guidelines and (2) insure proper consideration of human capabilities and limitations in the developing system. This guidance shall be derived from sources such as expert judgement, design guidelines and standards, and quantitative (e.8., anthropometric) and qualitative (e.g., relative effectiveness of differing types of displays for different conditions) data. Procedures shall be employed to ensure HSI adherence with standards.

8. HFE/HSI problems shall be resolved using studies, experiments, and laboratory tests, $0 . g$.

- Mockups and models may be used to resolve access, workspace and related HFE problems and incorporating these solutions into system design

- Dynamic simulation and HSI prototypes shall be evaluated for use to evaluate design details of equipment requiring critical human performance

- The rationale for selection of design/evaluation tools shall be documented

9. Human factors engineering shall be applied to the design of equipment and software for maintainability, testing and inspection.
10. HSI design elements shall be evaluated to assure their accoptability for task performance and HFE, criteria, standards, and guidelines.

11. The offort shall be performed using the following documents as guidance:

NUREG-0696: Functional criteria for emergency response facilities, 1980, (U.S. Nuclear Regulatory Commission).

NUREG-0700: Guidelines for control room design reviews, 1981, (U.S. Nuclear Regulatory Commission).

NUREG-0800: Standard review plan (Rev 1), 1984, (U.S. Nuclear Regulatory Commission).

NUREG/CR-5908: Advanced human-system interface design review guideline, 1992, (U.S. Nuclear Regulatory Commission - O'Hara, et al.).

EPRI NP-4350: Human engineering design guidelines for maintainability, 1985, (Electric Power Research Institute Pack R., et al.).

EPRI NP-3659: Human factors guide for nuclear power plant control room development, 1984, (Electric Power Research Institute - Kinkade, R.G., and Anderson, J.).

EPRI NP-3701: Computer-generated display system guidelines (Vols 1\&2), 1984, (Electric Power Research Institute - Frey, R. et al.).

IEC 964: Design for control rooms of nuclear power plants, 1989, (Bureau Central de la Commission Electrotrotechnique Internationale).

ANSI HFS-100: American national standard for human factors engineering of visual display terminal workstations, 1988, (American National Standards Institute).

Human-computer interface style guide (Version 1), 1992, (Department of Defense - Defense Information Systems Agency).

MIL-HDBK-759A: Human factors engineering design for army materiel, 1981, (Department of Defense).

MIL-STD-1472D: Human engineering design criteria for military systems, equipment and facilities, 1989, (Department of Defense).

DOD-HDBK-761A: Human engineering guidelines for management information systems, 1990, (Department of Defense). 
ESD-TR-86-278: Guidelines for designing wser interface software, 1986, (Department of Defenco).

\section{Implementation Plan}

The plan shall doscribe the devigner's approach to HumanSystem interface design. The Human-Systom interface design implementation plan shall addres:

- I\&C requirements analysis and dosign

- compare task requirements to I\&C availability

- Modifications to I\&C Inventory

- General HSI appronch selection

- Trade Studies

- Analyses

- The criteria to be used to meet General Criterion (selection and design of HSI hardware and software approaches), described above

- HFE design guidance dovelopment and documentation

- HSI detailed design and evaluations

- Use of design/evaluation tools such as prototypes shall be specifically identified and rationale for selection

\section{Analysis Results Renort}

The report shall address the following:

- Objectives

- Description of the methods

- Identification of any deviations from the implementation plan

- Results and discussion

- Conclusions

- Recommendations/implications for HSI design

\section{HSI Desion Team Fraluation Report}

The report shall addrees the following:

- The review methodology and procedures

- Compliance with implementation plan procedures

- Review findings

\subsection{Element 7 - Plant and Emergency Operating Procedure Development}

\section{DESIGN COMMITMENT:}

Plant and emergency operating procedures shall be doveloped to support and guide human interaction with plant systems and to control plant-related events and activities. Human engineering principles and criteria shall be applied along with all other design requirements to dovelop procedures that are tochnically accurate, comprehensive, explicit, easy to utilize, and validated. The types of procedures covered in the element are:

- plant \& system operations (including start-up, power, and shutdown operations)

- abnormal \& emergency operations

- preoperational, start-up, and surveillance tests

- alarm response

\section{INSPECTION/TEST/ANALV'SIS:}

- A plant and emergency operating procedure development implementation plan shall be developed.

- The procedures shall be developed in accordance with the plan and the results will be documented in a procedure development report.

- The procedure development shall be reviewed by the HSI design team and shall be documented in an evaluation report.

\section{DESIGN ACCEPTANCE CRITERIA:}

\section{General Criteria}

1. The task analysis shall be used to specify the procedures for operations (normal, abnormal, and emergency), test, maintenance and inspection.

2. The basis for procedure development shall include:

- Plant design bases

- system-based technical requirements and specifications

- the task analyses for operations (normal, abnormal, and emergency) 
- significent buman actions identified in the HRA/PRA

- initiating events to be considered in the EOPs chall include those events present in the design bases.

3. A Writer's Guide shall be developed to establish the process for doveloping technical procedures that aro complete, accurate, consistent, and casy to undenetand and follow. The Guide shall contain sufficiently objective criteria so that procedures developed in accordance with the Guide shall bo consistent in organization, style, and content. The Guide shall be used for all procedures within the scope of this Element. The Writer's Guide shall provide instructions for procedure content and format (including the writing of action steps and the specification of acceptable acronym lists and acceptable terms to be used).

4. The content of the procedures shall incorporate the following elements:

- Title

- Statement of applicability

- References

- Prerequisites

- Precautions (including warnings, cautions, and notes)

- Limitations and actions

- Required human actions

- Acceptance criteria

- Checkoff lists

5. All procedures shall be verified and validated. A review shall be conducted to assure procedures are correct and can be performed. Final validation of operating procedures shall be performed in a simulation of the integrated system as part of V\&V activities described in Element 8.

6. An analysis shall be conducted to determine the impact of providing computer-based procedures and to specify where such an appronch would improve procedure utilization and reduce operating crew errors related to procedure use.

7. The effort shall be performed using the following documents as guidance:

NUREG-0899: Guidelines for the preparation of emergency operating procedures, 1982, (U.S. Nuclear Regulatory Commission).

NUREG-1358: Lessons learned from the special inspertion program for emergency operating procedures, 1989, (U.S. Nuclear Regulatory Commission).
NUREG/CR-5228: Techniques for preparing flowchart format emergency operating procedures (Vols. 1\&2), 1989, (U.S. Nuclear Rogulatory Commission - Barnes, V. et al.).

NRC Regulatory Guide 1.33 (Rev. 2): Quality assurance program requirements, 1978, (U.S. Nuclear Regulatory Commicaion).

ANSI-N18. 7-1976: Administrative controls and quality assurance for the operational phase of nuclear power plants, 1976, (American National Standards Institute).

\section{Imolementution Plnn}

The plant end emergency operating procedure development implementation plan shall address:

- Identification of source data/information to be used as a besis for procedure dovelopment

- Methodology for the evaluation of procedures (plan shall describe tests and analyses that will be used to evaluate procedures)

- Requirements for the effective development and use of a Procedural Writer's Guide

- Procedures for training program - procedure integration

- Verification and validation procedures

- Procedure development documentation requirements

\section{Procedure Development Report}

The report shall address the following:

- Objectives

- Description of the methods Used

- Identification of any deviations from the implementation plan

- Recults, including a list of procedures developed, and a discuscion of the resulting procedures including ample procedures

- Conclusions

- Recommendations/implications for HSI design 


\section{Appendix J}

\section{HSI Desian Team Evaluation Report}

The report shall address the following:

- The review methodology and procedures

- Compliance with implementation plan procedures

- Review findings

\subsection{Element 8 - Human Factors Verification and Validation}

\section{DESIGN COMMITMENT:}

The successful incorporation of human factors engineoring into the final HSI design and the acceptability of the resulting HSI shall be thoroughly evaluated as an integrated system using HFE evaluation procedures, guidelines, standards, and principles.

\section{INSPECTION/TEST/ANALYSIS:}

- A human factors verification and validation implementation plan shall be developed.

- An analysis of human factors verification and validation shall be conducted in accordance with the plan and the findings will be documented in an analysis results report.

- The analyses shall be reviewed by the HSI design team and shall be documented in an evaluation report.

\section{DESIGN ACCEPTANCE CRITERIA:}

\section{General Criteria}

1. The evaluation shall verify that the performance of the HSI, when all elements are fully integrated into a system, meets (1) all HFE design goals as ('stablished in the program plan; and (2) all system functional requirements and support human operations, maintenance, test, and inspection task accomplishment.

2. The evaluation shall address:

- Human-Hardware interfaces

- Human-software interfaces

- Procedures

- Workstation and console configurations

- Control room design

- Remote shutdown system

- Design of the overall work environment
3. Individual HSI olements shall be evaluated in a static and/or "part-task" mode to assure that all controls, displays, and data processing that are required are available and that they are designed according to accepted HFE guidelines, standards, and principles.

4. The integration of HSI elements with each other and with personnel ahall be evaluated and validated through dynamic task performance ovaluation using ovaluation tools which are appropriate to the accomplishment of this objective. A fully functional HSI prototype and plant simulator shall be used as part of these evaluations. If an alternative to a HSI prototype is proposed its acceptability shall bo documented in the implementation plan. The evaluations shall have as their objectives:

- Adequacy of entiro HSI configuration for achievement of HFE design goals

- Confirm allocation of function and the structure of tasks assigned to personnel

- Adequacy of staffing and the HSI to support staff to accomplish their tasks

- Adequacy of Procedures

- Confirm the adequacy of the dynamic aspects of all interfaces for task accomplishment

- Evaluation and demonstration of error tolerance to human and system failures

5. Dynamic evaluations shall evaluate HSI under a range of operational conditions and upsets, and shall include:

- Normal plant evolutions (e.g., start-up, full power, and shutdown operations)

- Instrument Failures (e.g., Safety System Logic \& Control (SSLC) Unit, Fault Tolerant Controller (NSSS), Local "Field Unit" for MUX system, MUX Controller (BOP), Break in MUX line)

- HSI equipment and processing failure (e.g., loss of VDUs, loss of data processing, loss of large overview display)

- Transients (e.g., Turbine Trip, Loss of Offsite Power, Station Blackout, Loss of all FW, Loss of Service Water, Loss of power to selected buses/CR power supplies, and SRV transients) 
- Accidents (e.8., Main steamline break, Positive Reactivity Addition, Control Rod Ineertion at power, Control Rod Ejection, ATWS, and varioussized LOCAs)

6. Performance measures for dynamic ovaluations shall be adequate to test the achievement off all objectives, design goals, and performance requirements and shall include at a minimum:

- System performance measures relovant to safety

- Crow Primary Task Performance (e.8., tack times, proceduro violations)

- Crow Errors

- Situation Awareness

- Workload

- Crew communications and coordination

- Anthropometry evaluations

- Physical positioning and interactions

7. A verification shall be made that all issues documented in the human factors issue tracking system have been addressed.

8. A verification shall be made that all critical human actions as defined by the task analysis and PRA/HRA have be adequately supported in the design. The design of tests and evaluations to be performed as part of HFE V\&V activities shall specifically examine these actions.

9. The effort shall be performed using the following documents as guidance:

NUREG-0700: Guidelines for control room design reviews, 1981, (U.S. Nuclear Regulatory Commission).

NUREG-0800: Standard Review Plan (Rev 1), 1984, (U.S. Nuclear Regulatory Commission).

NUREG/CR-5908: Advanced human-system interface design review guideline (Draft), 1992, (U.S. Nuclear Regulatory Commission - O'Hara, et al.).

EPRI NP-3701: Computer-generated display system guidelines Nols 1\&2), 1984, (Electric Power Research Institute - Frey, R. et al.).

IEEE Std 845-1988: IEEE gulde to evaluation of manmachine performance in nuclear power generating station control rooms and other peripheries, 1988, (IEEE).

IEC 964: Design for control rooms of nuclear power plants, 1989, (Bureau Central de la Commission Electrotrotechnique Internationale).
AR 602-1: Human factors engineering program, 1983, (Department of Dofense).

TOP 1-2-610: Test operating procedure - Parts 1 \& 2, 1990, (Department of Defense).

DODI 50n0.2: Defense acquisition management policies and procedures, 1991, (Department of Defense).

\section{Implementution Plen}

The plan shall describe the designer's approach to human factore verification and validation. The human factors verification and validation implementation plan shall addreas:

- HSI element evaluation

- Control, Data Processing, Display audit

- Comparison of HSI element design to HFE guidelines, standards, and principles

- Dynamic performance evaluation of fully integrated HSI

- General objectives

- Test methodology and procedures

- Test participants (operators to participate in the test program)

- Test Conditions

- HSI description

- Performance measures

- Data analysis

- Criteria for evaluation of results

- Utilization of evaluations

- Documentation requirements

- Test \& evaluation plans and procedures

- Test Reports

\section{Analysis Results Report}

The report shall address the following:

- Objectives

- Description of the methods

- Identification of any deviations from the implementation plan

- Results and Discussion

- Conclusions

- Recommendations/implications for HSI design 


\section{Appendix J}

\section{HSL Desian Team Ey Juation Report}

The report shall addrees the following:

- The review methodology and procedures

- Compliance with implementation plan procedures

- Roviow findings

\section{REFERENCES}

ANSI (1976). Administrative controls and quality assurance for the operational phase of nuclear power plants (ANSI-N18. 7-1976), American National Standards Institute.

ANSI (1988). American national standard for human factors engineering of visual display terminal workstations (ANSI HFS-100), American National Standards Institute.

Bailey, R.W. (1982). Human performance engineering: A guide for system designers. Englewood Cliffs, NJ: Prentice-Hall, Inc.

Barnes, V. et al. (1989). Tectuniques for preparing flowchart format emergency operating procedures, Vols. 1 \& 2 (NUREG/CR-5228). U.S. Nuclear Regulatory Commission: Washington, D.C.

Booher, H.R. (Ed.) (1990). MANPRINT: An approach to systems integration. New York: Van Nostrand Reinhold.

Burgy, D. et al. (1983). Task analysis of nuclear power plant control room crews, Vols 1 \& 2 (NUREG/CR-3371). U.S. Nuclear Regulatory Commission: Washington, D.C.

DeGreene, K.B. (1970). Systems psychology. New York: McGraw-Hiil Book Company.

Department of Defense (1979a). Human engineering requirements for military systems, equipment and facilities (MIL-H-46855B). Washington, D.C.: Office of Management and Budget.

Department of Defense (1979b). Critical task analysis report (DI-H-7055). Washington, D.C.: Office of Management and Budget.

Department of Defense (1981). Human factors engineering design for army material ML-HDBK-759A (MI). Washington, D.C.: Department of the Army

Department of Defense (1983). Human factors engineering program (AR 602-1). Washington, D.C.: Department of the Army.
Departmeat of Defense (1985). Technical reviews and audits for systems, equipments, and computer software (ML-STD-1521B). Washington, D.C.: Department of the Air Force.

Department of Defense (1986). System safety program plan (DI-SAFT-80100). Washington, D.C.: Office of Management and Budget.

Department of Defense (1989a). Human engineering program plan (DI-HFAC-80740). Washington, D.C.: Office of Management and Budget.

Department of Defense (1989b). Human engineering design criteria for military systems, equipment and facilities (MIL-STD-1472D). Washington, D.C.: Office of Management and Budget.

Department of Defense (1989c). Manufacturer's MANPRINT management plan (OT-11920). Washington, D.C.: Office of Management and Budget.

Department of Defense (1990a). Manpower and personnel integration (MANPRINT) in the material acquisition process (AR 602-2). Washington, D.C.: Department of the Army.

Department of Defense (1990b). System engineering management plan (DI-MGMT-81024). Washington, D.C.: Office of Management and Budget.

Department of Defense (1990c). Test operating procedure - Parts 1 \& 2 (TOP 1-2-610). Washington, D.C.: Office of Management and Budget.

Department of Defense (1990d). Human engineering guidelines for management information systems (DODHDBK-761A). Washington, D.C.: Office of Management and Budget.

Department of Defense (1991a). Defense acquisition (DOD 5000.1). Washington, D.C.: Office of Management and Budget.

Department of Defense (1991b). Defense acquisition management policies and procedures (DODI 5000.2). Washington, D.C.: Office of Management and Budget.

Department of Defense (1991c). Human engineering procedures guide (DOD-HDBK-763). Washington, D.C.: Office of Management and Budget.

Department of Defense (1991d). Task performance analysis (MIL-STD-1478). Washington, D.C.: Office of Management and Budget. 
Departmeat of Dofence (1992). Human-computer interface style guide Nersion 1). Washington, D.C.: Office of Management and Budget.

Frey, R. ot al. (1984).: Computer-generased display system guidelines (Vols 1 \& 2) (EPRI NP-3701). Electric Power Research Institute.

Gagne, R. M., and Molton, A. W. (Bds.), Psychological principles in system development. Now York: Holt, Rinchart and Winston.

Hennesey, R. T. (1990). Practical humen performance testing and ovaluation. In Booher, H.R. (Ed.) MANPRINT: An approach to systems integration. Now York: Van Nostrand Reinhold.

International Eloctrotochnical Commission (1989). International standard: Design for control rooms of nuclear power plants (IEC 964). Genova, Switzerland: Bureau Central de la Commission Electrotechnique Internationale.

IEEE (1988). IEEE guide to the application of human factors engineering to systems, equipment, and facilities of nuclear power generating stations, Std 1023-1988.

IEEE (1988). IEEE guide to evaluation of man-machine performance in nuclear power generating station control rooms and other peripheries, Std 845-1988.

Kinkade, R. G., and Andereon, J. (1984). Human factors guide for nuclear power plant control room development (EPRI NP-3659). Electric Power Reseanch Institute.

Kockler, F., Withers, T., Podiack, J., and Giermen, M. (1990). Systems engineering management guide (Department of Defense AD/A223 168). Fort Belvoir, VA: Defense Systems Management College.

Meyer, O. (1991). The onsite analysis of the human factors of operating events (EGG-HFRU-9446), U.S. Nuclear Regulatory Commission.

Miller, R. B. (1953). A method for man-machine task analysis (Technical Report 53-137, June (AD 15921). Wright-Patterson AFB, Ohio: Wright Air Development Center.

O'Hara, J., and Higgins, J. (1992a). Preliminary review of the ABWR Design Implementation Process Plan (BNL Technical Report L2314-1-2/92P). Upton, New York: Brookhaven National Laboratory.
O'Hara, J., and Higgins, J. (1992b). Preliminary review of GE's responses 10 the ABWR Draft Safety Analysis Report human factors isswes (BNL Technical Report L2314-2-2/92P). Upton, New York: Brookhaven National Laboratory.

O'Harn, J. ot al. (1992). Advanced human-system Interface design review guideline (Draft NUREG/CR-5908). U.S. Nuclear Regulatory Commission: Washington, D.C.

Peck R., a al. (1985). Human engineering design guidelines for maintainability (EPRI NP-4350). Electric Power Research Institute.

Price, H., et al. (1982). The allocation of functions in man-machine systems: A perspective and literature review (NUREG/CR-2623). U.S. Nuclear Regulatory Commission: Washington, D.C.

Pulliam, R., ot al. (1983). A methodology for allocation nuclear power plant control functions to human and automated control (NUREG/CR-3331). U.S. Nuclear Regulatory Commission: Washington, D.C.

Smith, S. and Mosier, J. (1986).: Guidelines for designing user interface software (Department of Defense ESDTR-86-278). Washington, D.C.: Office of Management and Budget.

U.S. Nuclear Regulatory Commission (1978). Quality assurance program requirements (NRC Regulatory Guide 1.33 - Rev. 2). Washington, D.C.: U.S. Government Printing Office.

U.S. Nuclear Regulatory Commission (1980a). TMI-2 action plan (NUREG-0660). Washington, DC.

U.S. Nuclear Regulatory Commission (1980b). Clarification of TMI action plan requirements (NUREG-C737 and Supplements). Washington, D.C.

U.S. Nuclear Regulatory Commission (1980c). Functional criteria for emergency response facilities (NUREG-0696). Washington, D.C.

U.S. Nuclear Regulatory Commission (1981): Guidelines for control room design reviews (NUREG 0700). Washington, D.C.: U.S. Government Printing Office.

U.S. Nuclear Regulatory Commission (1982).: Guidelines for the preparation of emergency operating procedures ( NUREG-0899). Washington, D.C.: U.S. Government Printing Office. 


\section{Appendix J}

U.S. Nuclear Regulatory Commission (1984). Standand Review Plan, Rev. 1 (NUREG-0800). Washington, D.C.

U.S. Nuclear Regulatory Commission (1989). Lessons learned from the special inspection program for amergency operating procedures (NUREG-1358). Washington, D.C.: U.S. Government Printing Office.

U.S. Nuclear Regulatory Commission (1991). A prioritization of generic safety issues Main Report and Supplements 1-12) (NUREG-0933). Washington, D.C.: U.S. Government Printing Office.
U.S. Nuclear Regulatory Commission (1992). Shutdown and low-power operation at commercial nuclear power plants in the United States (Draft NUREG-1449). Washington, D.C.: U.S. Government Printing Office.

Van Cott, H. P., and Kinkade, R.G. (1972), Human engineering guide to equipment design (pp. 1-16). Washington, D.C.: U.S. Government Printing Office.

Woodson, W. E. (1981). Human factors design handbook. New York: McGraw-Hill Book Company. 


\section{Attachment \\ Operating Experience Review Inoves}

The accident at Thros Mile Island in 1979 and other reactor incidents have illustrated significant problems in the actual design and the design philosophy of NPP HSIs. There have been many atudies as a recult of these accidents/incidents. Utilities have implemented both NRC mandated changes and additional improvements on their own initiative. However, the changes we. of formed based on the constraints aseociated with backfits to existing control rooms (CRs) using early 1980s tochnology which limited the scope of corrective sctions that might have been considered, i.e., more effective fixes could be used in the case of a designing a now CR with the modom tochnology typical of advanced CRs. Problems and issues encountered in similar systems of previous designs should be identified and analyzed so that they are avoided in the development of the current system or, in the case of positive features, to ensure their retention.

Many of the issues identified below are broad and involve system design considerations that are broader than human factors alone. However, each has a humen fuctors component which should not be overlooked by the COL during the design and implementation procese. Thus for each issue identified below, a brief explanation of the HFE aspects of the issue are provided. These explanations are provided as examples only and are not intended to bo a complete specification of the HFE components of the issue (which should be addressed by the COL in the design specific treatment of the issue). Each of the issues listed below should be included in the operating experience review as part of the COL's design and implementation process.

The issues are organized into the following categories, based on the issues source:

- USI Issues

- TMI Issues

- NRC Generic Letters

- AEOD Studies

- Low Power and Shutdown Issues

\section{USI ISSUES}

1. A-44, Station blackout: This is a large and significant issue with many human factors related aspects, including controls, displays, training, and procedures.

2. A-47, Safety implications of control systems: This issue relates to the implications of failures of non-safety related control aystems and their interaction with control room operatorn.

3. B-17, Criteria for safety relatod operator action: This ienve involves the dovelopment of a time criterion for safety-rolated operator actions including a determination of whether automatic actuation is required.

4. B-32, Ice offects on safety related water supplies: The build-up of ice on service water intalies can occur gradually and can require improved instrumentation to allow operators to detect its occurrence before it causes syatem inoperability.

5. GI-2, Failure of protective devices on essential equipment: A large number of LERs bave noted the incapacitation of safety-related equipment due to the failure of protective devices such as fuses and circuit breakers. Operators are not always aware of the failure of the equipment due to the design of the instrumentation.

6. GI-23, Reactor coolant pump seal failures: This is a multi-faceted issue, which includes a number of propoesd resolutions. One sub-issue is the provision of adequate seal instrumentation to allow the operators to take corrective actions to prevent catastrophic failure of seals.

7. OI-51, Improving the reliability of open cycle service water systems: The build-up of clams, mussels, and corrosion products can cause the degradation of open cycle SW systems. Added instrumentation is one means of providing operators with the capability to monitor this build-up and take corrective action prior to loss of system functionality.

8. GI-57, Effects of fire protection system actuation on safety-related equipment: This issue resulted from spurious and inadvertent actuations of fire protection systems, often resulting from operator errors during testing or maintenance. Design of systems should prevent such errors to the extent possible.

9. GI-75, Generic implications of ATWS events at the Salem NPP: This GI has many sub-issues, several of which are related to human factors, for example, scrum data for post-scram analysis, capability for post-maintenance testing of RPS, and a specific sub-issue titled "roview of human factors issues."

10. GI-76, Instrumentation \& control power interactions: This issue raises several concerns, including control \& instrumentation faults the could 
blind or partially blind the operators to the etatus of the plant.

11. GI-96, RHR suction valve teeting: The design of the RHR suction valves with respect to valve position indication and instrumentation to dotoct potential leakage from high to low pressure arpes is important to the prevention of ISLOCAs. This is important for normal operations and for teating.

12. GI-101, Break plus single failure in BWR water lovel instrumentation: This issue attempts to ensure that robust information is availablo to the operators for both repctor water lovel and for plant atatus during the progression of an accident.

13. GI-105, Interfacing system LOCA at BWRs: This issue relates to pressure isolation valves for BWRs. Many failures in this area were due to personnel errors. The design should address human factors considerations to correct these potential orrors. (The NRC work in the ISLOCA area has generally determined that human factors is an area needing considerable attention apd which has contributed to a number of the ISLOCA precursor events.)

14. GI-110, Equipment protective devices of engineered safety features: There have been failures and incapacitation of ESF equipment due to the failure or intentional bypass by protective devices. Both the design of these protective devices and the appropriate indication to control room operators is important.

15. GI-116, Accident management: This issue relates to improved operator training and procedures for managing accidents beyond the design basis of the plant.

16. GI-117, Allowable equipment outage times for diverse, simultaneous equipment outages: A key aspect of this item is providing operators with needed assistance in identifying risk significant combinations of equipment outages. The information needed would include valve alignments, switch settings, as well as components declared inoperable.

17. GI-120, Online testability of protection systems: The designs for online testability should be careful to include appropriate human factors to ensure safe testing.

18. GI-128, Electrical power reliability: This issue includes power to vital instrument buses, DC power aupplies, and electrical interlocks. All of these ievies are atrongly dependent on proper indication and operator action for high roliability.

19. OI-130, Essential service water pump failures at multi-plant sites: This issue relates to the arrangoment of SW pumps and piping, including cross-ties at multi-unit sites. Both the arrangement and the operators' ability to monitor the status of croses ties is important. This itom mentions potential applicability to singlo unit sites also.

\section{TMI ISTUES}

1. 1v, HPCI and RCIC separation: the design should consider control room alarm and indication of the initiation levels and low:level restart values.

2. Ivi, Reduction oi challenges to SRVs: the design should consider control room alarm and indication of SRV status and important parameters.

3. Ivii, ADS study: determination of the "optimum" ADS for elimination of manual activation should consider the operator's need to monitor the system and should include an analysis of the time required for operators to perform manual backup if required.

4. Iviii, Automatic restart of Core Spray and LPCI: this issue involves allocation of function considerations in terms of automatic restart of a system following manual stoppage by the operators. Considerations of whether automatic restart should be available, how it should be implemented, and what alarm and indications are needed in the control room are required.

5. 1xi, Depressurization by means other than ADS: consideration of depressurization will involve the provision of alarms and indication in the control room. Some methods may also require operator actions which should be subject to the full design and implemestation process.

6. 1xii, Alternate hydrogen control systems: the evaluation of design alternatives for hydrogen control systems should include the information needs of the operators to assess the conditions which would require system initiation and the degree of automation of the systems.

7. 2iv, SPDS: the selection and display of important safety parameters and their integration into the overall design of the control room is a primary HFE issue. 

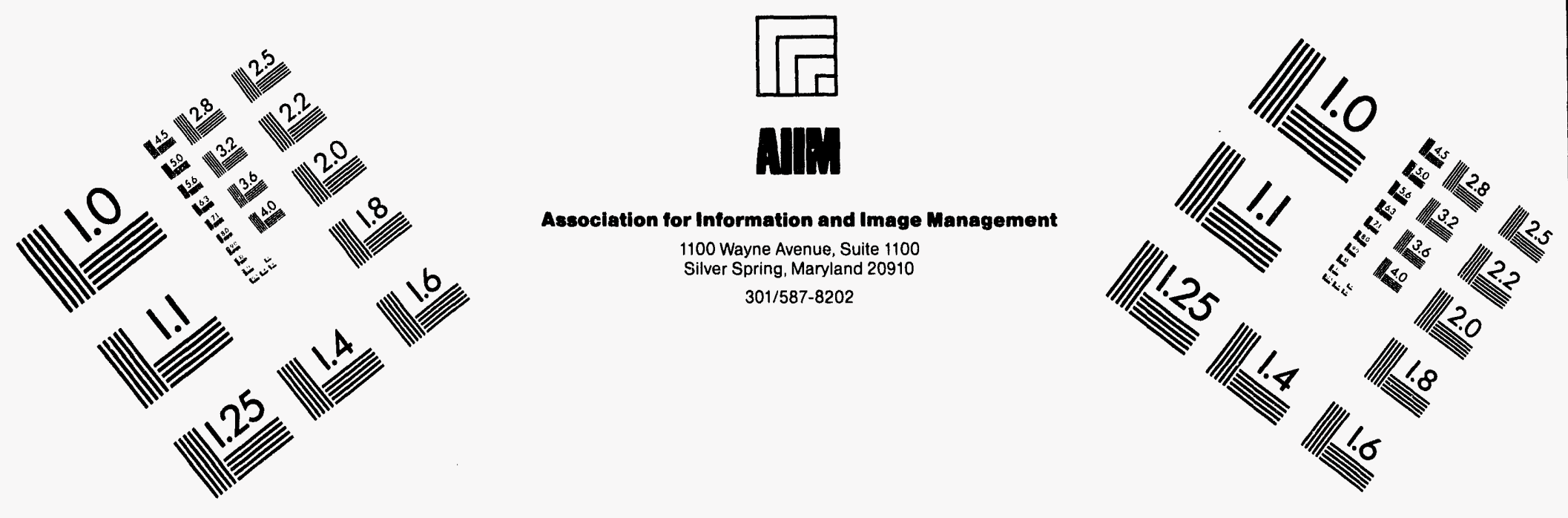

\section{Centimeter}

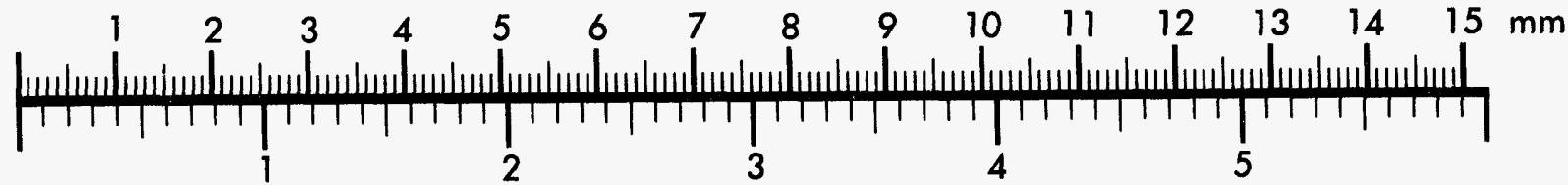
Inches

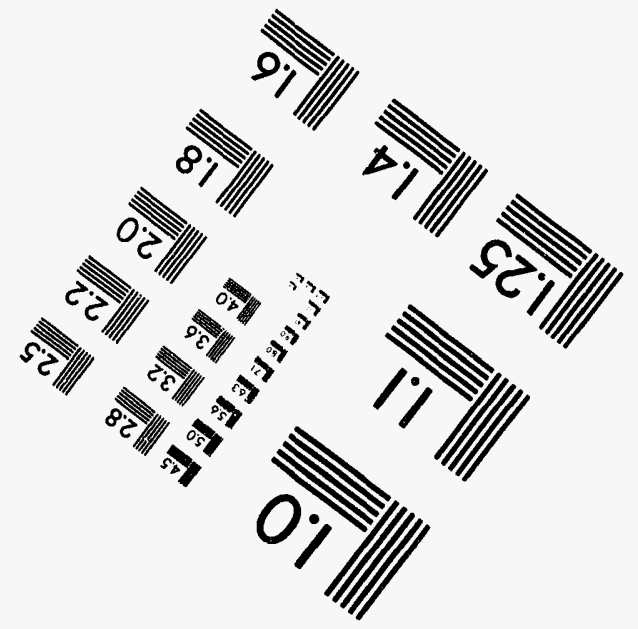

MANUFACTURED TO AIIM STANDARDS

BY APPLIED IMAGE, INC.

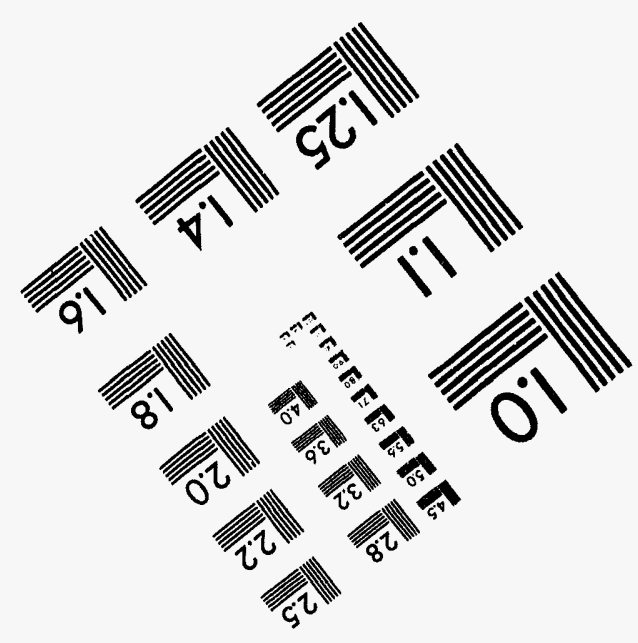



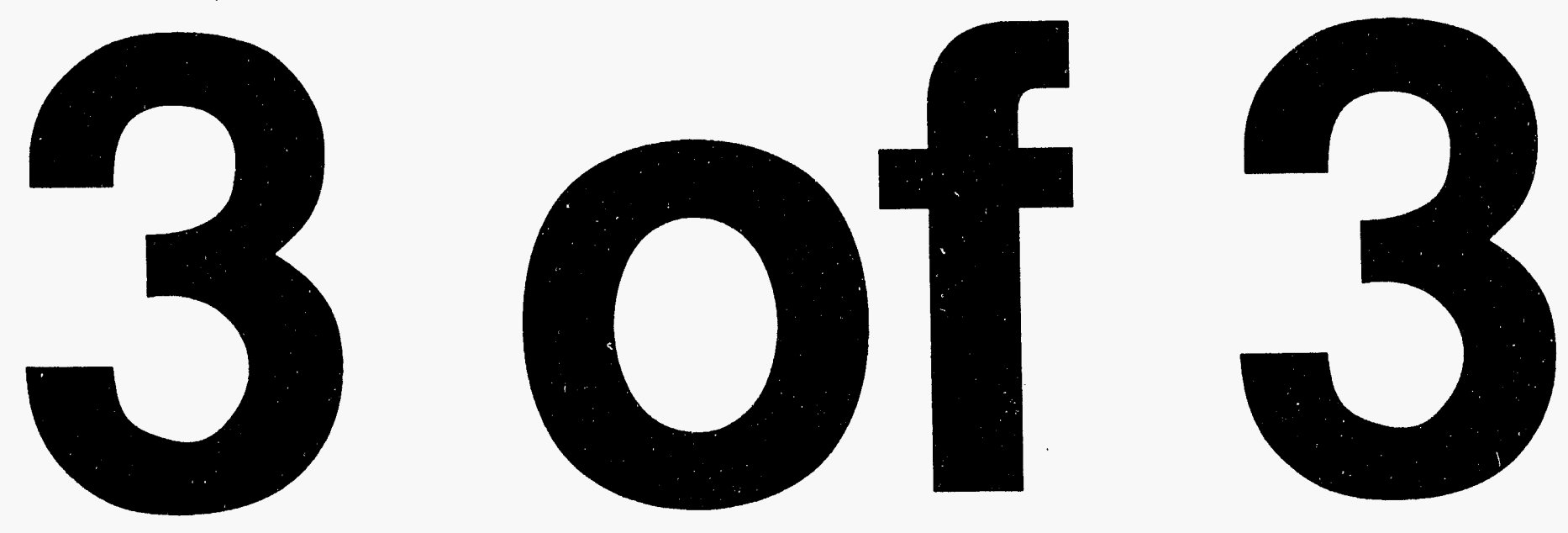
8. $2 v$, Automatic indication of bypassed and inoperable systems: providing operators with the capability to monitor the status of automatic systems is an important function of the control room information display system and an important component to the maintenance of the operators' situation awareness.

9. 2vi, Venting of noncondensible gases: operator monitoring of the status of noncondensible gases in the reactor coolant system and having clear, unambiguous indication of the conditions under which gas release must be initiated should be evaluated for HFE design implications.

10. 2xi, Direct indication of SRVs in control room: the alarming and indication of SRV status should be clear and unambiguous and should be evaluated for HFE design implications.

11. 2xvi, Number of actuation cycles for ECCS and RPS: as part of the specification allowable actuation cycles, the method that cycles will be defined, recorded, and tracked by the operating crew should be evaluated for HFE design implications.

12. 2xvii, Control room instrumentation for various parameters: the selection and display of important parameters and their integration into the overall design of the control room is a primary HFE issue.

13. 2xviii, Control room instrumentation for inadequate core cooling: the selection and display of important parameters and their integration into the overall design of the control room is a primary HFE issue.

14. 2xix, Instrumentation for post accident monitoring: the selection and display of important parameters and their integration into the overall design of the control room is a primary HFE issue.

15. 2xxi, Auxiliary heat removal systems design to facilitate manual/auto actions: the specification and evaluation of manual and automatic actions should be subject to the function allocation analyses performed as part of the design and implementation process.

16. 2xxiv, Recording of reactor vessel level: the selection and display of important parameters and their integration into the overall design of the control room is a primary HFE issue.

17. 2xxv, TSC, OSC and EOF: the design of the TSC, OSC and EOF should include HFE considerations to assure that the personnel located in these facilities can most effectively perform their safety:related functions. Poor HFE design of these facilities may interfere with the performance of operators in a well:designed control room.

18. 2xxvii, Monitoring of in:plant and airborne radiation: the selection and display of important parameters and their integration into the overall design of the control room is a primary HFE issue.

19. 2xxviii, Control room habitability: while potential pathways for radioactivity to impact control room habitability may be identified and design solutions developed to preclude such problems may be developed, the control room operating crew should be aware of potential pathways. If warranted, evaluations of methods to monitor in the control room the integrity of the design solutions and the presence of radiation in the pathways should be considered.

\section{NRC GENERIC LETTERS}

1. 91-06, Resolution of Generic Issue A-30, "Adequacy of Safety-Related DC Power Supplies," Pursuant to 10 CFR 50.54(f). In this generic letter, NRC proposes certain monitoring, surveillance, and maintenance provisions for safety-related DC systems.

2. 91-07 GI-23, "Reactor Coolant Pump Seal Failures" and its possible effect on Station Blackout.

This generic letter discusses the interaction between GI-23 and A-44, both of which have human factors aspects.

3. 91-11 Resolution of Generic Issues 48, "LCOs for Class 1E Vital Instrument Buses," and 49, "Interlocks and LCOs for Class 1E Tie Breakers" Pursuant to 10 CFR 50.54(f). This generic letter addresses several issues related to electrical systems including the reduction of human errors, control of equipment status, and testing.

\section{AEOD STUDIES}

The NRC's Office for Analysis and Evaluation of Operational Data (AEOD) conducted a program to identify human factors and human performance issues associated with operating events at nuclear power plants (e.g., Meyer, 1991). These reports should be reviewed by the COL in order to determine human factors issues that may impact the development, design, and evaluation of the ABWR. 


\section{Appendix J}

\section{LOW POWER AND SHUTDOWN ISSUES}

A current area of active NRC work is that of the risk associated with operation during low power and shutdown. The NRC has identified the operator-centered and human factors issues as particularly important in this area. The COL applicant should address those human factors finally developed by the NRC as a resolution to this issue. The most current status of these issues is contained in Draft NUREG-1449, "Shutdown and Low-Power Operation at Commercial Nuclear Power Plants in the United States." 


\section{APPENDIX K}

\section{IMPORTANT SAFETY INSIGHTS}

\section{Plant-Wide Insights}

(1) The COL applicant is to perform a seismic walkdown following the procedures of EPRI NP-6041 to confirm that the as-built plant matches the assumptions in the advanced boiling water reactor (ABWR) probablistic risk assessment (PRA)-based seismic margins analysis and to confirm that spatial systems interactions do not exist.

(2) The integrity of divisions is a very important assumption in the ABWR PRA. The PRA assumes that no high pressure of high temperature piping lines penetrate walls or floors separating two different safety divisions. Piping penetrations are qualified to the same differential pressure requirements as the walls or floors they penetrate.

(3) To prevent inadvertent spray or dripping from failing equipment, electric motors are all of drip proof design and motor control centers have NEMA Type 4 enclosures.

(4) The fire analysis assumes that the routing of piping or cable trays during the detailed design phase will conform with the fire area divisional assignments documented in the fire hazard analysis.

(5) Subsection 9A.5.5 under "Special Cases - Fire Separation for Divisional Electrical Systems" lists the only areas of the plant where there is equipment from more than one safety division in a fire area. These should be the only areas where multiple divisions share the same fire area.

\section{Combustion Turbine Generator}

The combustion turbine generator (CTG), in conjunction with the ac-independent water addition (ACIWA) system, have significantly reduced the estimated frequency of core damage from station blackouts (SBO) (the dominant contributor to core damage in most boiling water reactor (BWR) PRAs). In the ABWR standard safety analysis report (SSAR), GE indicated that each of the emergency dievel generators (EDGs) and the CTG can be used to power any of the loads identified in the PRA success criteria by manually closing selected breakers (note: EDGs cunnot power foedwater pumps). Even if offsite power is lost, the four onsite power sources can be used to power any safety or non-safety bus. This provides significant flexibility which helps reduce the risk from SBO and selected bus power losses. Procedures must be prepared by the COL applicant to direct this manual transfer of an EDG to a non-safety bus. GE has determined that the CTG has the highest fussell-vesely importance percentage (69.6 percent) of any plant SSC. This insight implies that the CTG should receive heightened attention in the COL applicant's DRAP and ORAP.

An important assumption about the CTG is that no plant support systems are needed to start or run the CTG. The CTO starts automatically and safety grade loads are to be added manually.

\section{AC-Independent Water Addition System}

This system is one of the single most important systems in the ABWR from the point of view of prevention and mitigation of severe accidents, since the accidents that have traditionally been identified in BWR PRAs as being the most challenging are SBO and transients with failure of various ECCS or cooling systems. This system also provides benefits for fires, internal floods, shutdown events, seismic events, and events where containment cooling is lost. It can provide water (as vessel makeup or drywell spray) from a diesel-driven pump or a fire truck.

The use of the system as a backup source of water to the drywell sprays is perhaps the single-most important feature for reducing the consequences of severe accidents in the ABWR. In this role the system serves to: (1) reduce containment overpressure and delay the time to actuation of containment overpressurization systems (COPS), (2) eliminate the potential for drywell overtemperature failure in those events in which debris may be dispersed to the upper drywell, and (3) mitigate the consequences of suppression pool bypass by condensing steam produced in the drywell.

The following are important aspects of the system, as represented in the PRA:

(1) a fire protection pump - will survive a design bases earthquake, diesel-driven pump (i.e., acindependent)

(2) connection provided outside of reactor building, which allows a fire truck to be used as a backup to the fire protection pumps

(3) system piping and valves configured to allow fire protection water to be used for either vessel makeup or drywell spray, but not both simultaneously

(4) all valves (including valves F017, F018, and F005 in the RHR system) and controls needed for system 
operation can be accessed and manually operated in a stmight-forward manner and can be operated successfully (including the environment the operator will be in, such as the radiation field following a vessel melt-through) following an earthquake, internal flood, fire, or internal ovent

(5) check valves provided to prevent backflow from the reactor coolant system

(6) orifices installed in the associated piping to restrict the injection rates to the vessel and drywell sprays

(7) water supply independent of the suppression pool and the condensate storage tank

\section{RCIC}

Reactor core isolation cooling (RCIC) is ac-independent and provides reliable high pressure injection. This makes RCIC particularly important in preventing SBO from leading to core damage. In addition RCIC is very important for mitigation of control room fires or other emergencies that require the evacuation of the control room. The following capabilities are important for RCIC:

1. RCIC needs to be able to operate for 8 hours following a SBO (using steam and dc power) and the batteries at the end of 8 hours need to have sufficient power in them to allow for RCS depressurization by the ADS. RCIC pump and turbine are assumed in the PRA to be able to operate for at least eight hours without room coolers.

2. For control room fires, the capability for local operation of RCIC outside the control room is very important.

3. Sensitivity studies that increased structures, systems and components (SSC) unavailabilities showed that an increase in RCIC unavailability would cause the greatest increase in estimated core damage frequency of any SSC. RCIC also was found to be the most sensitive system to increased outage time assumptions.

4. The suppression pool temperature up to which RCIC can operate is important for Class II sequences. The ABWR PRA assumes that RCIC can operate up to a suppression pool temperature of $76.7^{\circ} \mathrm{C}\left(170^{\circ} \mathrm{F}\right)$.
Beactor Buildine Cooline Water (RCW/Reactor Service Water (RSW)

The RCW and RSW systems are each designed with two parallel loops in each division. Each loop is capable of removing all component heat loads associated with the operation of the emergency core cooling system (ECCS) pumps. The parallel loops within each division substantially reduce the estimated core damage frequency.

\section{Automatic Standby Liquid Control System (SLCS) and Recirculation Pump Trip}

The ABWR has a reliable and diverse scram system with both hydraulic and electric run-in capabilities to reduce the probability of an ATWS. SLCS and recirculation pump trip provide backup reactor shutdown capability. Automatic initiation of SLCS avoids the potential for operator error associated with manual SLCS initiation.

\section{Reactor Internal Pump (RIP) Desien and Maintenance}

Every shutdown, a selected number of RIPs must be maintained. Maintenance on the secondary RIP seals requires removal of the motor, impeller and shaft, and the temporary bottom cover. The plug on the impeller shaft nozzle is the only protection against a major leak. If the operator were to remove the plug when the bottom cover was removed, the RPV would drain and recovery is improbable. GE has proposed that a new design of the plug be identified that will not allow plug removal with the bottom cover off. A design that solves this problem already exists overseas.

\section{Beactor Building}

A flood in the reactor building could fail ECCS equipment and other important equipment. The following are assumptions in the ABWR internal flooding analysis that limit the chances and increase the mitigation capabilities of the ABWR design:

1. The volume of the reactor building corridor on level B3F that surrounds the three ECCS divisions is sufficiently large to handle the biggest break that can occur (water from the suppression pool).

2. Suppression pool flooding in an ECCS room will reach equilibrium level below the ceiling of the ECCS room in which the flood occurred. 
3. Floor drains direct potential flood waters to rooms where sumps and sump pumps are located. The drain system is sized to withstand the maximum flood rate from a break in the fire water system. Sizing of the drain system is to include provisions for plugging of some drains by dobris.

4. Non-divisional drains will drain to the nondivisional sumps on appropriate floors.

5. Floor B1F of the reactor building has overfill lines on the non-divisional sumps outside secondary containment. If the sump pumps fail or the flow rate exceods the sump pump capacity, the lines will direct water to the non-divisional corridor of the first floor (B3F) inside secondary containment.

6. A water seal in the overfill line is provided to maintain secondary containment integrity.

7. The ABWR PRA flooding analysis assumes that on the B3F level, all wall and ceiling penetrations are above the maximum water level of all potential floods. Doors communicating from the ECCS pump rooms to the corridor on the B3F level are water tight doors.

8. If a flood were to occur during shutdown, some of the ECCS rooms may be open for maintenance. ABWR procodures specify that one safety division will bo maintained intact at all times during shutdown.

Similarly, a fire in the reactor building could damage important equipment. The smoke control system in secondary containment is important in helping to prevent the migration of smoke and hot gas layers from a faulted division to another. This is accomplished by pressurizing the surrounding areas so that the smoke will be contained. This capability and its adequacy should be confirmed.

\section{Control Building}

Flooding in the control room can lead to core damage. The following design features are important in preventing flooding in the control building:

1. The ABWR internal flooding analysis assumes that flooding of the control building from the UHS cannot be maintained by gravity alone. To limit the consequences of a RSW line break, the RSW system will be designed so that the UHS cannot drain into the Control Building by gravity.
2. To limit the consequences of a RSW line break, there is a maximum of $\mathbf{4 0 0 0}$ meters of pipe (2000 each for supply and return) betwsen the UHS and the RCW/RSW room, which can be discharged to the RCW/RSW room following RSW pump trip.

3. Floor drains direct potential flood waters to rooms where sumps and sump pumps are located. The drain system is sized to withstand the maximum flood rate from a break in the fire water system. Sizing of the drain system is to include provisions for plugging of some drains by debris.

\section{Service Water Pump House}

Previous PRAs and reliability studies have shown that loss of service water can be an important contributor to core damage. The service water pump house, which is outside the ABWR certification scope, is a building that must be designed to remove the following concerns:

1. Prevent fires or internal floods from impairing multiple safety trains.

2. Prevent common cause failures such as intake blockage from debris from affecting multiple trains.

\section{Circulating Water System}

Flooding from the circulating water system (an unlimited water supply) can lead to flooding of other buildings that do contain safety related equipment. The following design features help reduce the chances that a circulating water system break will cause core damage:

1. The circulating water system (CWS) has three pumps and each pump has an associated motor operated isolation valve. To limit the consequences of a CWS break in the turbine building, for cases where the heat sink is at an elevation higher than grade level of the turbine building, an additional isolation valve is installed in each line.

2. Internal floods are prevented/mitigated in part by automatic actions and operator actions. To prevent flooding of areas surrounding the condenser pit, there are to be water level sensors (two-out-of-fourlogic) to alarm to the control room if the water level gets too high in the pit and trip the circulating water and turbine service water pumps and close isolation valves in both systems. 


\section{Turbine Service Water System}

Flooding from the turbine service water system (TSW) (an unlimited water supply) can lead to flooding of other buildings that do contain safety related equipment. The following design features help reduce the chances that a TSW break will cause core damage:

1. The TSW has two pumps and each pump has an associated motor operated isolation valve. To limit the consequences of a TSW break in the turbino building, for cases where the heat sink is at an elevation higher than grade lovel of the turbine building, an additional isolation valve is installed in each line.

2. Internal floods are prevented/mitigated in part by automatic actions and operator actions. To prevent flooding of areas surrounding the condenser pit, there are to be water level sensors (two-out-of-fourlogic) to alarm to the control room if the water level gets too high in the pit and trip the turbine service water and circulating water pumps and close isolation valves in both systems.

\section{Reactor Service Water System}

Flooding from the reactor service water (RSW) system (an unlimited water supply) can lead to core damage. The following design features help reduce the chances that a RSW system break will cause core damage:

1. A break in the RSW system can cause a flood in the control building that could lead to core damage. For this reason, an anti-siphon capability is installed in the RSW lines to prevent uncontrolled flooding of the Control Building should the RSW isolation valves fail to close on a RSW pipe break.

2. Water level sensors will be installed in the reactor building cooling water (RCW)/RSW rooms in the control building. These sensors are used to alert the operators to flooding in the rooms and send signals to trip RSW pumps and close isolation valves in the affected system. The high and low level sensors are diverse from one another and each set is arranged in a two-out-of-four logic.

\section{Reactor Water Cleanup System}

The reactor water cleanup (CUW) system provides some benefit in the ABWR PRA by removing decay heat at high pressure. It would only be used in this mode if the containment cooling mode of the RHR system was disabled.
The isolation valves in the RWCU system must be capable of isolating against a differential pressure equal to the operating pressure of the reactor coolant system in the event that there is a LOCA in the RWCU.

The reliability of these isolation valves should match the reliability assumed in the ABWR PRA [COL action item to include in RAP]. Temperature sensitive equipment in the reactor water cleanup system should be able to remain functional or should be isolated when the CUW system is ueed as a decay heat removal path at high temperatures. Temperature sensitive equipment such as the resin beds is to be isolated automatically on high water temperature or manually by operator action. The entire CUW system is not to isolate on high temperature of the incoming water.

\section{Ultimate Heat Sink}

The ABWR PRA assumed that the service water system and the ultimate heat sink (UHS) would work well in tandem to deliver adequate cooling to needed equipment. There was no detailed examination of these systems in the PRA since they are not in the certification scope. The UHS and the service water pump house should be designed in such a manner so that common cause failure of service water is extremely low. A site-specific PRA must be developed by the COL applicant to show that there are no vulnerabilities (e.g., due to debris clogging of the intake, internal or external fires, external or internal floods) in the ultimate heat sink and the service water pump house.

\section{Remote Shutdown Panel}

1. The ABWR PRA fire analysis found that use of the remote shutdown panel is very important in mitigating fires in the control room. The design of the remote shutdown panel was enhanced by GE adding controls for a fourth SRV (three needed to depressurize, plus one for a single failure).

2. The ABWR decay heat removal reliability study found that operator actions making use of the remote shutdown panel were important during modes 3, 4, and 5 .

\section{Residual Heat Removal System}

The residual heat removal (RHR) system is very important for the removal of decay heat during normal shutdown and in its ECCS function as low pressure core flooder. The following design features and assumptions are important for assuring the RHR system is capable of removing decay heat in various modes and for various accident and transients: 
1. An important failure mode for beyond design bases earthquakes is the failure of the RHR heat exchanger in such a manner as to drain the suppression pool. In the ABWR PRA-based soismic margins analysis, the RHR heat exchanger is assumed to bave a HCLPF of $0.7 \mathrm{~g}$.

2. In modes 3, 4, and 5, the permissives and inhibits associated with the RHR Mode switch ensure that valve line ups are correct for most RHR functions, thereby helping to prevent inadvertent diversion of water from the RPV.

3. The ABWR PRA and the DHR reliability study have shown that it is important for the RHR not to fail as an intersystom LOCA. The RHR system has the capability to withstand normal reactor system pressures without the piping reaching its ultimate capacity. The DHR reliability study indicated that RHR valve interlocks are important in preventing low pressure RHR piping from being inadvertently connected to systems at high pressure.

4. The ABWR DHR reliability study determined a number of configurations of equipment for modes 3, 4, and 5 such that the estimated core damage frequency from decay heat removal failure conservatively was less than 1 in a million per year. An important assumption in this study was that the three RHR trains would be configured as follows during modes 3, 4, and 5: one loop would be isolated, in standby, and operable with no equipment in maintenance; a second loop would be the operating decay heat removal loop; the third loop would be in maintenance.

5. Shutdown cooling piping connects to a nozzle in the RPV at an elevation that is above the top of the active fuel. This reduces the chances of uncovering the core by vessel drain down.

\section{High Pressure Core Flood System}

1. HPCF pump B can be operated independently of the essential multiplexing system. This feature is an important factor in reducing the chances of the plant going to core damage since this design should reduce the chance of a common cause failure disabling all ECCS pumps.

2. The HPCF pumps will be able to pump water as hot as $171^{\circ} \mathrm{C}\left(340^{\circ} \mathrm{F}\right)$.

\section{Three BCCS Tring}

The barrier between each of the three safety divisions in the $A B W R$ is at a minimum a 3 hour fire barrier that also resists intornal flood pressures. This design assumption significantly reduces the chance of an internal flood or fire propagating and causing core damage.

\section{Pipine Upgrades to Prevent ISLOCAs}

In SECY-93-087 it was recommended that ALWR designers reduce the possibility of a loss of coolant accident outside of containment by confirming that all systems (to the extent practical) and subsystems connected to the reactor coolant system (RCS) can withstand full RCS pressure. Intersystem LOCAs are a concern because many releases associated with them are not contained, held up, or scrubbed, but rather are released directly to the environment. GE has assured the NRC that the interfacing systems to the RCS can withstand full RCS pressure.

\section{Lack of Recirculation Piping}

There are no large pipes (i.e., $>2$ inches in diameter) that penetrate the ABWR vessel below the level of the core. This has virtually eliminated loss-of-coolant accidents (LOCAs) as a severe accident concern for the ABWR.

\section{Electrically Driven Control Rod Insertion}

In many BWR PRAs, ATWS is a significant contributor to core damage frequency and risk. The diversity (electrically driven) of the fine motion control rod system is important in lowering the estimated core damage frequency for ATWS events for the ABWR.

\section{Electrical Wirine Penetrations}

Wiring penetrations between divisions should be rated as three hour fire barriers and should be capable of preventing water/oil from an internal flood from migrating to another division.

\section{Power Supply}

The ABWR PRA expects that loss of all dc power will lead to core damage. In the ABWR design, seismically induced failure of dc power cable trays or the batteries themselves will prevent the emergency diesel generators from starting and loading. DC power cable trays and the emergency batteries are the only non-building SSCs that could, by themselves, decrease the HCLPF of any accident sequence below $0.5 \mathrm{~g}$. This would occur if the HCLPF of the dc power cable trays or the batteries were to fall below 
0.5g. The DC cable trays and power supplies should be well anchored and carefully designed to handle a desizn beses $0.3 \mathrm{~g}$ earthquake. The ABWR PRA-based seismic margins analysis assumed that the HCLPF of the dc cable trays was $0.7 \mathrm{~g}$ and the HCLPF of the de power system (batteries and rectifier) is $\mathbf{0 . 7 4 g}$.

\section{Safety System Loric and Control}

There are four divisions of self-tested safety system logic and control (SSLC) instrumentation (two-out-of-four logic). The ABWR PRA assumes that this will be a highly reliable configuration to actuate ESF core cooling and heat removal system as well as actuating the CRD scram system for defense against ATWS events. Assumptions about SSLC reliability and redundancy in the PRA substantially reduce the estimated cure damage frequency.

Off-line testing for faults not detected by the continuous self-test feature were judged to be important in the PRA analysis.

\section{Fire Truck}

The ACIWA makes use of a fire truck connection to provide water if the motor and diesel-driven pumps are unavailable. The PRA assumes the reliability of the fire truck is 0.99 .

\section{Reactor Pressure Vessel Isolation on Low Water Level}

The ABWR shutdown reliability study indicated that the isolation of lines connected to the RPV on a low water level signal in modes 3,4 , and 5 prevents uncovering of the fuel for many potential RPV drain down events.

\section{Operator Check That Watertight Doors Are Dogged}

The internal flooding analysis assumes that all watertight doors are closed and dogged to prevent floods from propagating from one area to another. The watertight doors are alarmed to alert the security that a watertight door is open, but will not alarm to indicate that a door is not dogged. To guard against a door being left undogged, operators should check the doors every shift to confirm that they are closed and dogged.

\section{Suppression Pool Bypass}

The suppression pool is an important containment feature for severe accident progression and fission product removal, since releases from the reactor vessel are either directly routed to the pool (e.g., transients with actuation of ADS) or pass through the pool via the drywell-wetwell connecting vents. However, the suppression pool function can be compromised in the ABWR design in the following ways:

- a single failure of a wetwell/drywell vacuum breuker (i.e., a stuck open vacuum breaker), or by excessive leakage of one or more vacuum breakers

- unisolated main steam line breaks

- rupture of the SRV discharge line(s) in the wetwell air spece

- inadvertent opening and failure to close sample lines, drywell purge lines, and containment inerting lines

- unisolated LOCAs in the reactor water cleanup and RCIC systems

The following are important to assuring a low risk from wetwell/drywell vacuum breaker bypass, as modelled in the PRA and are to be included in DRAP:

(1) low probability of vacuum breaker leakage (PRA ussumes a leakage probability of 0.18 per demand on system)

(2) low probability that the vacuum breakers fail to close (PRA assumes a failure to close probability of about 0.0005 per demand per valve)

(3) a high availability of drywell or wetwell sprays (and ACIWA as a backup) to condense steam which bypasses the suppression pool

(4) position indication switch on each vacuum breaker valve that will indicate the valve to be open should the gap between the disk and seating surface exceed $0.9 \mathrm{~cm}$. (A gap less than $0.9 \mathrm{~cm}$ is necessary to permit credit for aerosol plugging taken in the GE analysis.)

(5) placement and shielding of the vacuum breakers such that pool swell associated with COPS actuation will not impact operation of the valves.

In addition, it is important to verify that the vacuum breakers are closed. To achieve this control room alarms will be installed to indicate if all the vacuum breakers are closed. (This reduces the potential for suppression pool bypass by assuring that the plant is not operated with a stuck open vacuum breaker, and that pre-existing leakage paths will be limited to small flow areas.) 
The following are important to assuring a low risk from unisolated main steam line breaks:

(1) two air-operated, spring close, failed closed isolation valves in each line.

(2) automatic MSIV actuation by redundant solenoids through two-out-of-four logic.

The following are important to assuring a low risk from rupture of the SRV discharge lines, particularly in seismic events:

(1) discharge lines are designed and fabricated to Quality Group C requirements.

(2) welds in the airspace region of the wetwell are nondestructively examined to the requirements of ASME Section III, Class 2 3. discharge lines are capable of accommodating seismic events at an acceleration level of $0.6 \mathrm{~g}$ with a high confidence that there is a low probability of failure (HCLPF).

The following is important to assuring a low risk from suppression pool via the sample, drywell purge, and containment inerting lines:

(1) lines will be sealed closed during power operation, and under administrative control.

The following are important to assuring low risk from LOCAs outside containment:

(1) redundant and seismically-qualified CUW system isolation valves, qualified to close under postulated break conditions

(2) blowout panels in the RCIC and RWCU divisional areas which prevent overpressurization and impacts on equipment in adjacent areas and other divisions

(3) reliable seating of redundant feedwater, SLIC, and ECCS discharge check valves

\section{Lower Drywell Desion}

The design of the ABWR lower drywell/reactor cavity is such that there is a low probability that the cavity will be flooded at the time of reactor vessel failure, but a high probability that the cavity will be flooded subsequent to vessel failure. A dry cavity at the time of vessel failure reduces the potential for large ex-vessel steam explosions, whereas the subsequent flooding of the cavity helps minimize the impact of core concrete interactions.
The following ABWR design features are important to assuring a dry cavity at the time of vessel failure:

(1) lack of any direct pathways by which water from the upper drywell (e.g., from drywell sprays) can drain to the lower drywell, other than by overflow of the suppression pool,

(2) negligible probability of premature or spurious actuation of the passive flooder valves at temperatures less than $500 \mathrm{~F}$ or under differential pressures associated with reactor blowdown and pool hydrodynamic loads, and

(3) a capability to accommodate approximately $7.2 E 5 \mathrm{~kg}$ of water in the suppression pool from external sources before the pool overflows into the lower drywell.

The following features are important to assuring reactor pedestal and containment integrity for beyond 24 hours following reactor vessel failure, and to rendering CCI-induced containment failure a relatively insignificant contributor to risk.

(4) a $1.7 \mathrm{~m}$ thick reactor pedestal capable of withstanding approximately $1.55 \mathrm{~m}$ of erosion from CCI without loss of structural integrity,

(5) the use of basaltic concrete in the floor of the lower drywell, which minimizes the production of noncondensable gases,

(6) sump shield to prevent core debris from entering the lower drywell sump, and

(7) the lower drywell flooder system

Note: The lower drywell flooder system in the ABWR provides a passive means of adding water to the lower drywell following reactor vessel breach. This water would cover the core debris, thereby enhancing debris coolability, cooling the drywell, and providing fission product scrubbing. The passive flooder system is a backup to other means of lower drywell water addition in the $A B W R$, including: (1) continued water addition through the breached reactor vessel and (2) suppression pool overflow as a result of water addition from water sources outside containment. PRA-based sensitivity studies indicate that the incremental risk reduction offered by the passive flooder is system is minimal. This is because of credit taken in the $A B W R$ for continued water addition using the ACIWA mode of RHR. 


\section{Containment Ultimate Preasure Capacity}

The ultimate pressure capacity of the ABWR contrinment is limited by the drywell bead, whose failure mode is plastic yield of the torispherical dome. Subsequent to the original SSAR submittal, GE increased the ultimate pressure capability of the drywell head from 100 psig to 134 psig, and increased the COPS eetpoint from the original value of 80 psig to the final value of 90 psig. The strengthening of the drywell head increases the ability of the containment to withstand rapid pressurization events, such as direct containment heating, without loss of structural integrity, and provides additional margin between the COPS setpoint and the drywell failure pressure, thereby reducing the potential for drywell failure prior to COPS actuation. The drywell head is the limiting component in the containment preesure boundary during slow overpressure events.

\section{Containment Overpressure Protection System (COPS)}

COPS is part of the atmospheric control system in the ABWR, and consists of a pair of rupture disks installed in a 10-inch diameter line which connects the wetwell airspace to the stack. COPS provides for a scrubbed release path in the event that containment pressure cannot be maintained below the structural limit of the containment. Without this system, late containment overpressure failures would be expected to occur in the drywell, resulting in unscrubbed releases. COPS provides a significant benefit by reducing the source terms for late releases, and minimizing the potential for containmentfailure-induced loss of core cooling (e.g., in Class II sequences). The following are important features of the system, as modelled in the PRA:

(1) COPS actuation at $90 \mathrm{psig}+/-5$ percent

(2) piping (and disk) designed to flow steam at a rato equivalent to 2 percent reactor power, and accommodate peak pressure loads associated with system actuation

(3) no normally-closed or automatic isolation valves in vent path

(4) two normally-open, fail-open isolation valves in the vent path, manually operated from the control room, with key-lock switches

(5) capability of related isolation valves to close against full vent pressure.

\section{Contrinment Inertine System}

Because the ABWR containment will be inerted during power operation, hydrogen combustion is not considered to be an important containment challenge, and was not modelled in the PRA.

To confirm the velidity of this treatment, strict controls must be placed on the period of time that the reactor tan be operated with the containment do-inerted.

\section{Direct Containment Heatine (DCH)}

DCH is the only severe accident phenomena that represents a significant challenge to containment integrity (5 percent probability of containment failure given reactor veseel failure at high pressure). The impact of DCH is "controlled" in ABWR by reducing the frequency of high pressure reactor vessel failure using ADS (30 percent of vessel failures). The following aspects of ADS should be confirmed by ITAAC and RAP:

(1) reliability/availability consistent with Level 1 PRA assumptions [DRAP],

(2) no dependency on ac-power,

(3) availability of sufficient de power to actuate ADS in a long term SBO (following loss of RCIC due to battery depletion).

There are no specific ABWR containment design feature to deal with DCH loads other than the general arrangement of the drywell and wetwell, and connecting vents, which provide for a series of 90 -degree bends that debris must traverse in order to reach the upper drywell.

\section{Important Human Actions}

Human actions with high risk impact for the ABWR were identified based on the PRA and supporting analyses. Section 19D.7 of the SSAR includes a listing of these actions, classified into three categories corresponding to the COL-actions necessary to confirm the validity of the PRA treatment of the action: (1) critical tasks, (2) maintenance items, and (3) COL procedures and planning.

1. The items identified as "critical tasks" in 19D.7, as well as actions to recover emergency diesels, have the greatest impact on core damage frequency and risk for the ABWR. Accordingly:

- these actions are to be addressed by the COL applicant as part of the detailed design of humansystem interfaces 
- the following will bo provided for each action:

a. clear unambiguous indication of conditions requiring the ection

b. the operator must have tho capability to perform the sction in a straight-forward manner

c. the operator must have clear written operating procedures regarding the actions to be taken

d. the operator must have thorough training in the conditions requiring the setion.

2. The probability of miscalibrating single and multiple sensors was assigned very low values on the basis that the COL-applicant would incorporate a special procedure governing calibration activities. At a minimum, the COL-applicants maintenance procedures for sensor calibration should require that whenever a sensor is found to be out-of-tolerance, before the sensor is recalibrated, the calibration instrumunt is first chocked or an alternate instrument is used to confirm the condition.

3. For items ideatified as "COL Procedures and Planning" itoms, the COL-applicant is to develop procedures to confirm that these sctions can be effectively implemented.

\section{Importence/Uncertainty Analyses}

Examination of the top ten ovents contributing to uncertainties in the estimate of the ABWR core damage frequency (CDF) revealed that nine of these events were identified by importance analyses as leading contributors to CDF.

The highest contributor to uncertainties in the CDF as well as the CDF estimate was RCIC test and maintenance. The remsining top contributors to uncertainties (and CDF) are listed in SSAR Table 19D.10-5. 

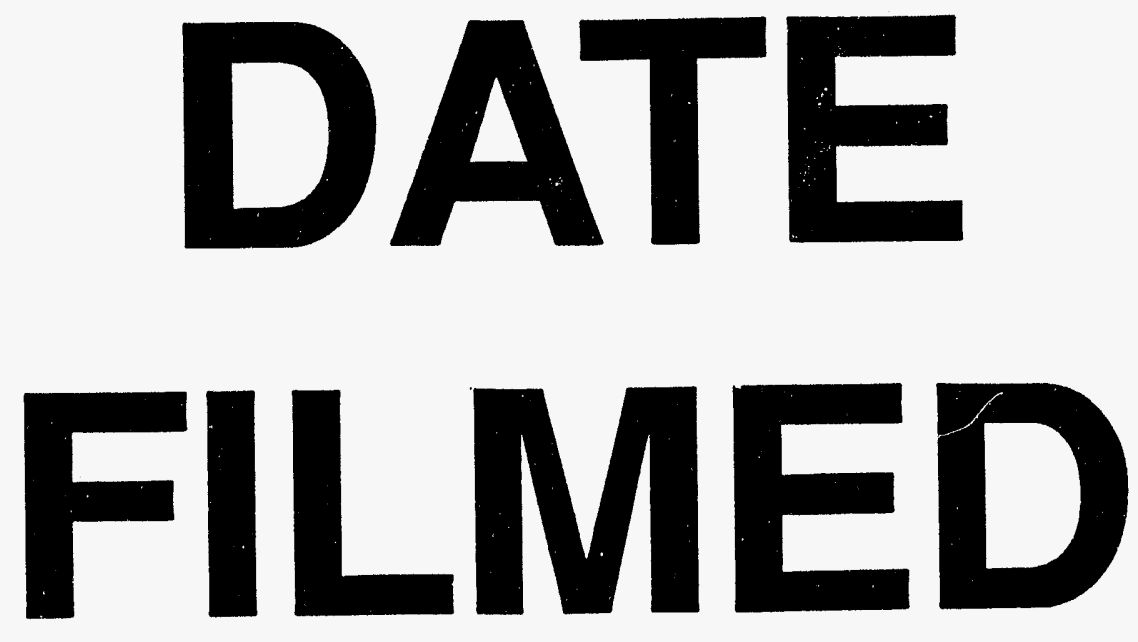

$9 / 20 / 94$
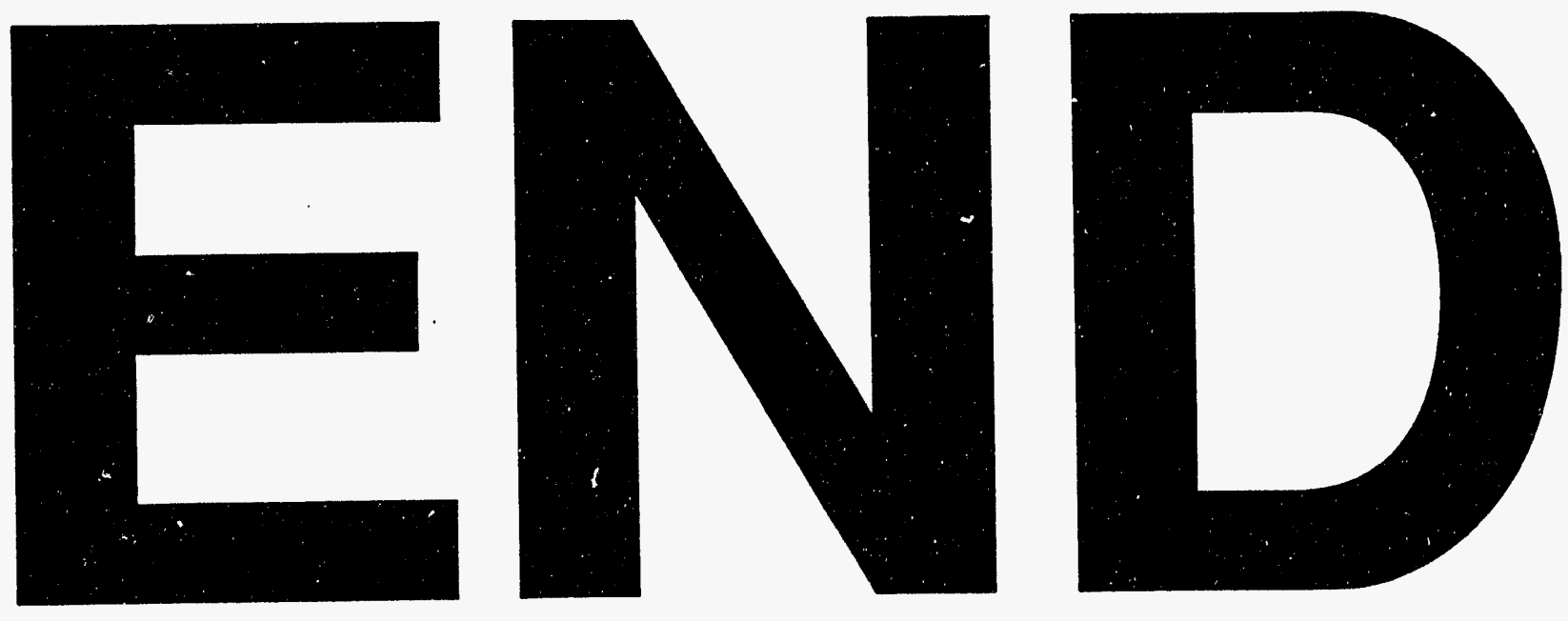
